\title{
Differences in methane production, storage and transport among plant community types during a wet summer at Mer Bleue bog, Ottawa
}

\author{
by
}

\author{
Elizabeth Cowan
}

A thesis submitted to the Faculty of Graduate and Postdoctoral Affairs in partial fulfillment of the requirements for the degree of

Master of Science

in

Geography

Carleton University

Ottawa, Ontario

(C) 2015, Elizabeth Cowan 


\begin{abstract}
This study assessed indicators of methane $\left(\mathrm{CH}_{4}\right)$ production, storage and transport among plant community types to investigate the spatial and temporal variability in $\mathrm{CH}_{4}$ dynamics during a wet summer at the Mer Bleue bog. Community type was largely differentiated by sedge (Eriophorum vaginatum) presence, which increased as the average water table depth approached the surface. Stable isotope analysis identified $\mathrm{CO}_{2}$ reduction as the dominant methanogenic pathway in all plots, but with more depleted source signatures as percent Eriophorum increased, possibly due to $\mathrm{CH}_{4}$ transport via aerenchymatous tissues. Increasing peat temperature contributed to increasing $\mathrm{CH}_{4}$ concentrations at $50 \mathrm{~cm}$, near the long-term average water table, and dissolved organic carbon and total dissolved nitrogen at all depths, and a seasonal increase in chamber $\mathrm{CH}_{4}$ emissions. Plant community did not relate to spatial differences in pore water characteristics, but increasing percent Eriophorum was associated with greater $\mathrm{CH}_{4}$ emissions.
\end{abstract}




\section{ACKNOWLEDGEMENTS}

I would like to thank everyone who contributed to this research. In particular, I express my deepest appreciation for the continual guidance and insight provided by my supervisor, Dr. Elyn Humphreys. She demonstrated endless patience and provided constant support as I navigated through my graduate studies at Carleton University. Her steadfast optimism and persistent encouragement opened numerous doors and pushed my work to the highest possible standard. In addition, I thank my committee member, Dr. Murray Richardson and mentors Dr. Tim Moore, Dr. Ruth Varner and Dr. Carmody McCalley. Your research served as a model for my own work and your collective input was invaluable throughout the development of this thesis. Furthermore, the support, reflections and interest expressed by participants of the Mer Bleue Working Group and Peatland Workshop meetings were greatly appreciated.

A sincere thank you to my field assistant, Rachel Canham, who was always eager and willing to help and provided intellectual, physical and moral support throughout our field season at Mer Bleue. I am also very appreciative of the assistance that Claire Elliott provided in the field during the fall months for Mer Bleue maintenance. A special thank you to Dr. Mike Treberg for his help with building our sampling devices and maintaining the site. Thank you to Mike Dalva and Michael Templeton from McGill University, who provided vital assistance in the field and in the lab for DOC, TDN and SUVA analysis. I am appreciative of the isotope gas analysis provided by Annalisa Sarno ( $\mathrm{PhD}$ Candidate) and Dr. Hinsby Cadillo-Quiroz at Arizona State University. I am also indebted to Alice Wilson, who graciously supplied her ArcMap skills on short notice. 
This research was made possible through the funding support of the National Sciences and Engineering Research Council (NSERC), Ontario Ministry of Environment and Climate Change, Ontario Graduate Scholarship (OGS) program, and Carleton University. In addition, thank you to Ottawa's National Capital Commission (NCC) for providing site access and support.

Finally, I would like to acknowledge the support provided by my friends and family throughout each stage of this thesis. Your motivational words and attentiveness inspired me to enhance my critical thinking while maintaining a healthy lifestyle, and I would not have completed this research without you. Special thanks to Dad's garage, which was ready and willing to tackle all our crazy projects! A simple "thank you" could never suffice, but know that I am infinitely grateful for each and every one of you. 


\section{TABLE OF CONTENTS}

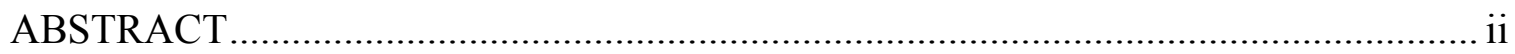

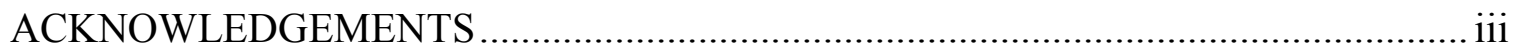

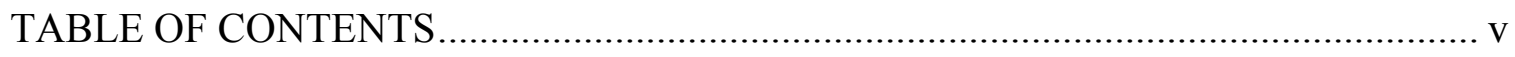

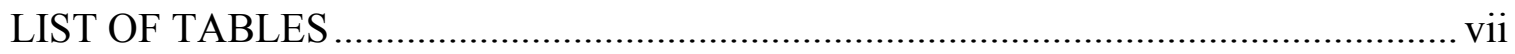

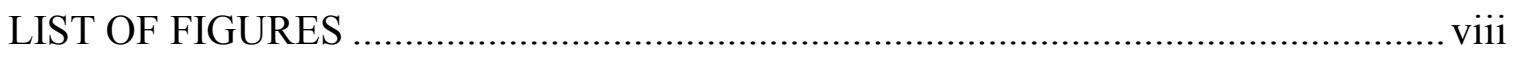

LIST OF SYMBOLS AND ABBREVIATIONS ……................................................... xii

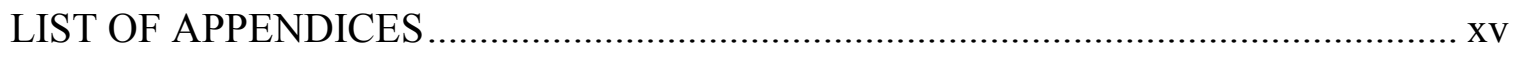

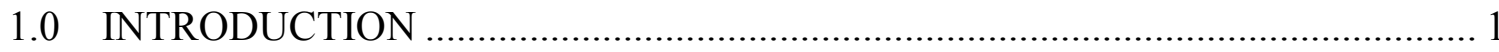

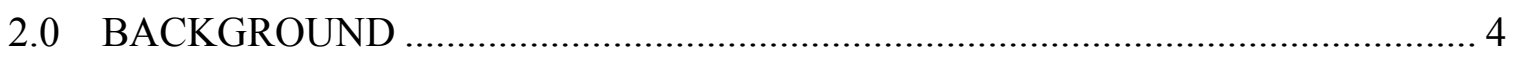

2.1 Northern peatlands and climate …………………….................................... 4

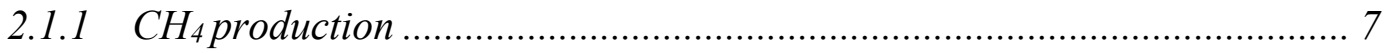

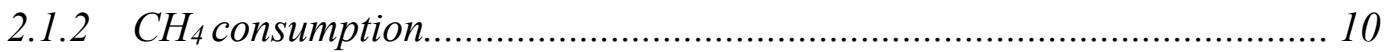

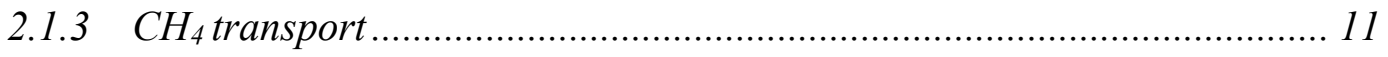

2.2 Environmental controls on peatland $\mathrm{CH}_{4}$ emissions ....................................... 14

2.2.1 Redox boundary associated with WT position ....................................... 14

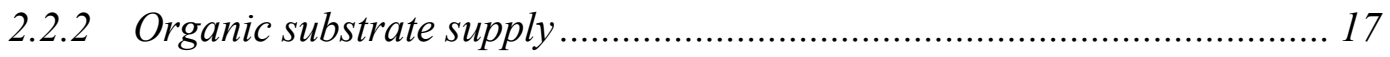

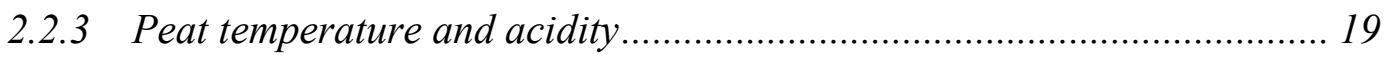

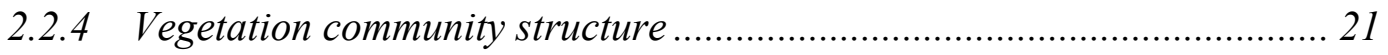

2.3 Measurement techniques and approaches........................................................ 22

2.3.1 Autochamber $\mathrm{CH}_{4}$ flux measurements ................................................. 22

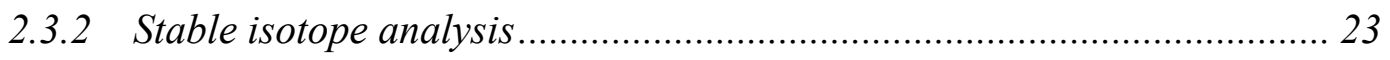

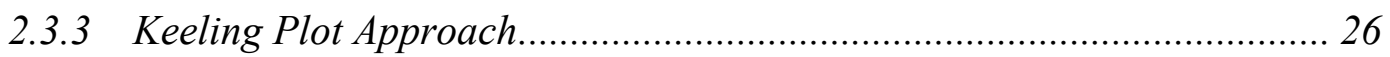

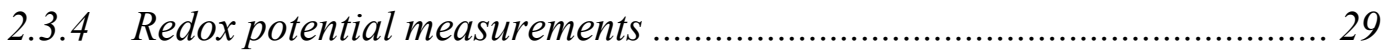

2.3.5 Pore water collection and analysis........................................................ 30

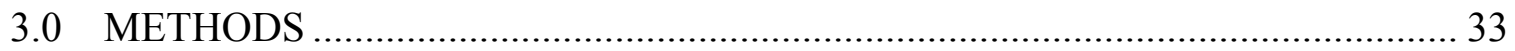




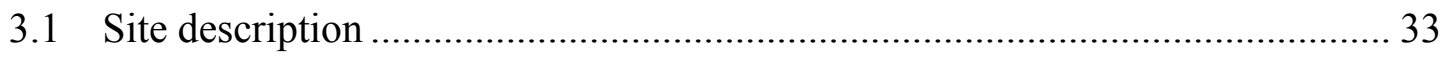

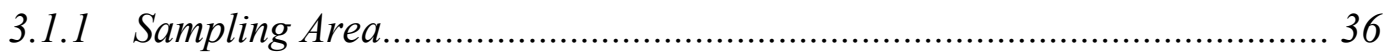

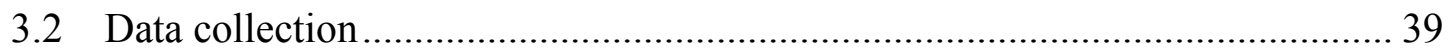

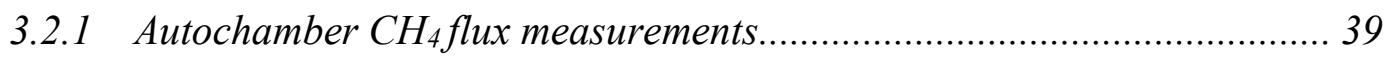

3.2.2 Static chamber $\mathrm{CH}_{4}$ flux measurements ................................................ 42

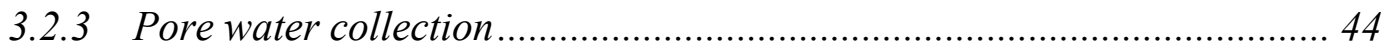

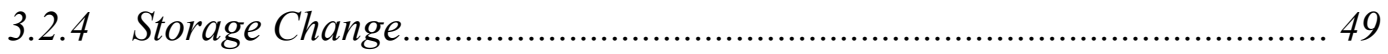

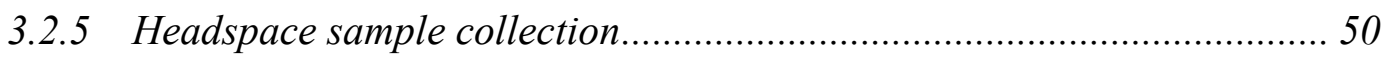

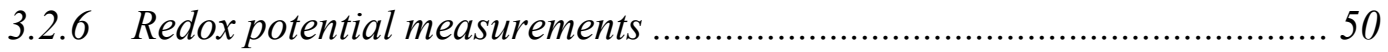

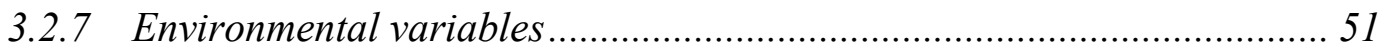

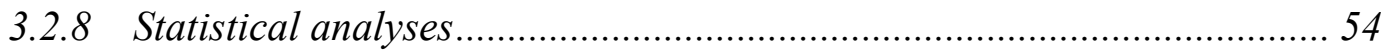

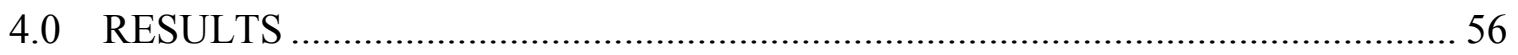

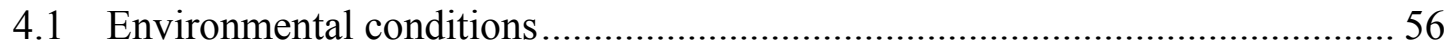

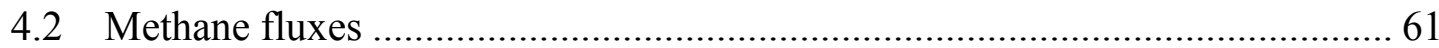

4.3 Redox potential measurements ........................................................................ 71

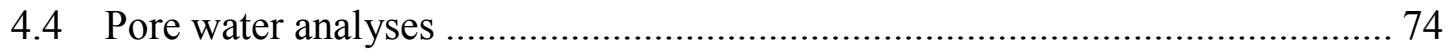

$4.5 \mathrm{CH}_{4}$ production pathway ………………………...................................... 82

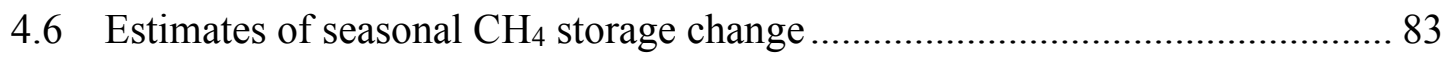

4.7 Relationships among indicators of $\mathrm{CH}_{4}$ production, storage and transport....... 86

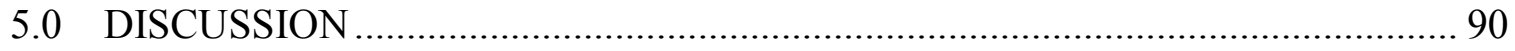

6.0 CONCLUSION

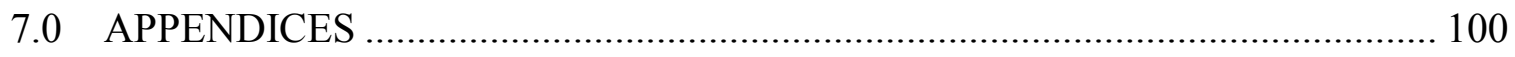

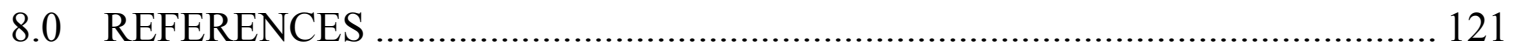




\section{LIST OF TABLES}

Table 2-1: Redox pairs and redox values (Eh) at transformation at reference $\mathrm{pH}$ of 7.0 (Adapted from Vorenhout et al. 2004)

Table 3-1: Vegetation characteristics at the 9 chamber plots including dominance (\%) of vascular and nonvascular plant species, growing season maximum biomass leaf area index (LAI, $\left.\mathrm{m}^{2} \mathrm{~m}^{-2}\right)$, total and Eriophorum vaginatum $(E V)$ green LAI, and maximum percent of $E V$ cover. 38

Table 3-2: Frequency and method of manual and automated measurements for environmental variables.

Table 4-1: Comparison of mean daily $\mathrm{CH}_{4}$ flux, water table (WT) and $50 \mathrm{~cm}$ peat temperature at the tower site $\left(\mathrm{T}_{50 \mathrm{~cm}}\right)$ for Chamaedaphne, Ledum and Eriophorumdominated communities at Mer Bleue, 2014. Standard deviation is given in parentheses. $\mathrm{CH}_{4}$ fluxes with different superscripts across a row are significantly different at the $\alpha=0.10$ level when accounting for the chamber as a random effect (or repeated measure) in a mixed model and using Student's $t$-test post-hoc analysis. Similarly, WT depths with different superscripts across a row are significantly different at the $\alpha=0.10$ level when accounting for the chamber as a random effect (or repeated measure) in a mixed model and using Student's $t$-test post-hoc analysis. . 63

Table 4-2: Pearson correlations for averaged chamber-specific variables between DOY 212 and 255. All pore water and temperature variables are from the $50 \mathrm{~cm}$ depth. Correlations in bold $(\mathrm{p}<0.05)$ and italics $(\mathrm{p}<0.10)$ are significant. $\mathrm{N}=9$. Variables include: community type, total green hits LAI (LAI), percent LAI attributed to Eriophorum vaginatum (EV \%), total biomass LAI as measured with the LAI-2000 (LAI2000), $\mathrm{CH}_{4}$ flux $\left(\mathrm{F}_{\mathrm{CH}}\right)$, storage change of pore water $\mathrm{CH}_{4}\left(\mathrm{~S}_{\mathrm{CH}}\right)$, pore water $\mathrm{CH}_{4}$ concentration $\left(\mathrm{PW}_{\mathrm{CH} 4}\right), \delta^{13} \mathrm{C}-\mathrm{CH}_{4}$ source signature $\left(\delta^{13} \mathrm{C}-\mathrm{CH}_{4}\right)$, water table depth (WT), dissolved organic carbon (DOC), total dissolved nitrogen (TDN), carbon to nitrogen ratio $(\mathrm{CN})$, absorbance at $254 \mathrm{~nm}\left(\mathrm{Abs}_{254}\right)$, and specific ultraviolet absorbance at $254 \mathrm{~nm}\left(\mathrm{SUVA}_{254}\right)$. 


\section{LIST OF FIGURES}

Figure 2-1: Methane production, consumption and transport pathways in peat layers (Adapted from Le Mer \& Roger 2001).

Figure 2-2: The Keeling Plot method as described by Equation 10. Inverse $\mathrm{CH}_{4}$ concentrations $\left(\mathrm{mol} \mu \mathrm{mol}^{-1}\right)$ are plotted vs. isotope ${ }^{13} \mathrm{C} /{ }^{12} \mathrm{C}$ ratios (\%). The isotopic signatures of sampled $\mathrm{CH}_{4}\left(\delta^{13} \mathrm{C}_{\mathrm{a}}\right)$ and background $\mathrm{CH}_{4}\left(\delta^{13} \mathrm{C}_{\mathrm{b}}\right)$ are shown with open circles. The y-intercept (-71.7\%o) is interpreted as the isotopic signature of the $\mathrm{CH}_{4}$ source, $\delta^{13} \mathrm{C}_{\mathrm{s}}$ 28

Figure 3-1: Location of the tower site, gas analyzers and logging equipment, and chamber area at the Mer Bleue research site. The star, representing the tower site, is located at $45^{\circ} 24^{\prime} 33^{\prime \prime}$ N, $75^{\circ} 31^{\prime} \quad 07^{\prime \prime}$ W. Map data: Google, Digital Globe (Imagery Date: 9/24/2013).

Figure 3-2: Photos of a) the autochamber system at Mer Bleue used to measure $\mathrm{CH}_{4}$ fluxes at b) the plant community scale with c) a Plexiglas ${ }^{\circledR}$ dome fitted to a PVC collar.

Figure 3-3: Photos of manual chamber collars inserted into the peat at a) E-M 1, b) E-M 2 and c) E-M 3 Eriophorum plants.

Figure 3-4: Example setup of instrumentation at an autochamber collar showing sampling depths for pore water samplers, Hydrosense probe, redox probe and soil thermocouples (TC) inside and outside the chamber collar. Note that only a single soil thermocouple profile was installed and was located near the flux tower $\sim 50 \mathrm{~m}$ from the autochambers. All other sensor placements and depths are to scale.

Figure 3-5: Photos of pore water sampling instrumentation where a) a pore water sipper was used to collect pore water from depths $<50 \mathrm{~cm}$ below peat surface and permanent $b$ ) pore water seepers and c) piezometers were used to collect pore water at 50,65 and $80 \mathrm{~cm}$. After samples were collected, d) pore water filtration and equilibration for isotope analysis was carried out in the field at a small equipment hut.

Figure 4-1: Mean ( $\pm 1 \mathrm{SD})$ daily average air temperature (lines) and total monthly rainfall (bars) from May through September 2014 at Mer Bleue peatland in reference to 1981-2010 climate normals measured at the Ottawa Macdonald-Cartier International Airport (Environment Canada 2014).

Figure 4-2: Mean daily depth to water table from peat surface $(\mathrm{cm})$ measured at Chamaedaphne, Ledum and Eriophorum-dominated communities and tower site at Mer Bleue, 2014. The long-term mean water table position recorded at the tower site between 1998 and 2014 is shown for comparison. 
Figure 4-3: Daily mean a) air temperature $\left(\mathrm{T}_{\text {air }},{ }^{\circ} \mathrm{C}\right)$ and b) $10 \mathrm{~cm}$ peat temperature $\left(\mathrm{T}_{10 \mathrm{~cm}}\right.$ $\left.{ }^{\circ} \mathrm{C}\right)$ for the Chamaedaphne, Ledum and Eriophorum-dominated communities during the 2014 measurement period. 59

Figure 4-4: Daily mean peat temperature at the tower site $\left(\mathrm{T}_{\text {tower }},{ }^{\circ} \mathrm{C}\right)$ measured at 20,40 , 50,65 , and $80 \mathrm{~cm}$ below peat surface during the 2014 measurement period. 60

Figure 4-5: Mean daily $\mathrm{CH}_{4}$ flux $\left(\mathrm{mg} \mathrm{m}^{-2} \mathrm{~h}^{-1}\right)$ for Chamaedaphne, Ledum and Eriophorum-dominated communities at Mer Bleue during the 2014 measurement period (DOY 120-270). Open circles indicate days when manual static chamber flux sampling measurements were collected at the Eriophorum community chambers. . 62

Figure 4-6: Mean daily $\mathrm{CH}_{4}$ flux $\left(\mathrm{mg} \mathrm{m}^{-2} \mathrm{~h}^{-1}\right)$ emitted from 3 Chamaedaphne-dominated autochambers (C-A 1, 2, 3) (circles), 3 Ledum-dominated autochambers (L-A 1, 2, 3) (diamonds) and 3 Eriophorum-dominated manual chambers (E-M 1, 2, 3) (squares) at Mer Bleue during the 2014 measurement period (DOY 120-270).

Figure 4-7: The relationship between $10 \mathrm{~cm}$ peat temperature $\left(\mathrm{T}_{10 \mathrm{~cm}},{ }^{\circ} \mathrm{C}\right)$ and $\log \mathrm{CH}_{4}$ flux $\left(\mathrm{mg} \mathrm{m}^{-2} \mathrm{~h}^{-1}\right)$ emitted from 3 Chamaedaphne-dominated autochambers (C-A 1, 2, 3) (circles), 3 Ledum-dominated autochambers (L-A 1, 2, 3) (diamonds) and 3 Eriophorum-dominated manual chambers (E-M 1, 2, 3) (squares) at Mer Bleue for manual sampling day data (DOY 132-255).

Figure 4-8: The relationship between $50 \mathrm{~cm}$ peat temperature $\left(\mathrm{T}_{50 \mathrm{~cm}},{ }^{\circ} \mathrm{C}\right)$ and $\log \mathrm{CH}_{4}$ flux ( $\mathrm{mg} \mathrm{m}^{-2} \mathrm{~h}^{-1}$ ) emitted from 3 Chamaedaphne-dominated autochambers (C-A 1, 2, 3) (circles), 3 Ledum-dominated autochambers (L-A 1, 2, 3) (diamonds) and 3 Eriophorum-dominated manual chambers (E-M 1, 2, 3) (squares) at Mer Bleue for manual sampling day data (DOY 132-255).

Figure 4-9: Relationship between mean depth to water table (cm) and $\log \mathrm{CH}_{4}$ flux $(\mathrm{mg}$ $\mathrm{m}^{-2} \mathrm{~h}^{-1}$ ) from 3 Chamaedaphne-dominated autochambers (C-A 1, 2, 3) (circles), 3 Ledum-dominated autochambers (L-A 1, 2, 3) (diamonds) and 3 Eriophorumdominated manual chambers (E-M 1, 2, 3) (squares) at Mer Bleue for manual static chamber sampling days (DOY 132-255) during the 2014 measurement period. ..... 70

Figure 4-10: Relationship between mean seasonal depth to water table $(\mathrm{cm})$ and mean $( \pm \mathrm{SD})$ seasonal $\log \mathrm{CH}_{4}$ flux $\left(\mathrm{mg} \mathrm{m}^{-2} \mathrm{~h}^{-1}\right)$ from 3 Chamaedaphne-dominated autochambers (C-A 1, 2, 3) (circles), 3 Ledum-dominated autochambers (L-A 1, 2 , 3) (diamonds) and 3 Eriophorum-dominated manual chambers (E-M 1, 2, 3) (squares) at Mer Bleue for manual static chamber sampling days (DOY 132-255) 2014. The solid black line shows the linear regression calculated to predict $\log \mathrm{CH}_{4}$ flux based on mean daily water table, where predicted $\log \mathrm{CH}_{4}$ flux is equal to 2.435 +0.03162 (WT) $\mathrm{mg} \mathrm{m}^{-2} \mathrm{~h}^{-1}$ when WT is measured in $\mathrm{cm}$ from the peat surface at each chamber.

Figure 4-11: Mean daily redox potential $(\mathrm{mV})$ referenced to $\mathrm{Ag} / \mathrm{AgCl}$ reference electrode with $3 \mathrm{M} \mathrm{KCl}$ filling solution and corrected for $\mathrm{pH}$ of 4 . Sampled at chamber E-M 1 (Eriophorum) for peat depths of 20cm, $40 \mathrm{~cm}, 60 \mathrm{~cm}$, and $80 \mathrm{~cm}$ at Mer Bleue, 
2014. Mean daily depth to water table $(\mathrm{cm})$ is shown for reference (dotted black line) on the secondary $y$-axis.

Figure 4-12: Mean daily redox potential $(\mathrm{mV})$ referenced to $\mathrm{Ag} / \mathrm{AgCl}$ reference electrode with $3 \mathrm{M} \mathrm{KCl}$ filling solution and corrected for $\mathrm{pH}$ of 4 . Sampled at chamber E-M 2 (Eriophorum) for peat depths of $20 \mathrm{~cm}, 40 \mathrm{~cm}, 60 \mathrm{~cm}$, and $80 \mathrm{~cm}$ at Mer Bleue, 2014. Mean daily depth to water table $(\mathrm{cm})$ is shown for reference (dotted black line) on the secondary y-axis.

Figure 4-13: Mean daily (a) dissolved organic carbon (DOC, $\mathrm{mg} \mathrm{L}^{-1}$ ), (b) total dissolved nitrogen (TDN, mg L ${ }^{-1}$ ), (c) specific ultraviolet absorbance at $254 \mathrm{~nm}\left(\mathrm{SUVA}_{254}, \mathrm{~L}\right.$ $\left.\mathrm{m}^{-1} \mathrm{mg}^{-1} \mathrm{DOC}\right)$, and (d) carbon to nitrogen ratio $(\mathrm{C} / \mathrm{N})$ for all chambers at various depths during the 2014 measurement period. 75

Figure 4-14: Mean daily (a) dissolved organic carbon (DOC, $\mathrm{mg} \mathrm{L}^{-1}$ ), (b) total dissolved nitrogen (TDN, mg L-1), (c) specific ultraviolet absorbance at $254 \mathrm{~nm}\left(\mathrm{SUVA}_{254}, \mathrm{~L}\right.$ $\left.\mathrm{m}^{-1} \mathrm{mg}^{-1} \mathrm{DOC}\right)$, and (d) carbon to nitrogen ratio $(\mathrm{C} / \mathrm{N})$ for Eriophorum-dominated chambers at various depths during the 2014 measurement period. 76

Figure 4-15: Pore water profiles of mean $( \pm \mathrm{SE})$ dissolved $\mathrm{CH}_{4}$ concentrations $\left(\mu \mathrm{mol} \mathrm{L}{ }^{-1}\right)$ for three vegetation communities at Mer Bleue. Depth was measured from peat surface $(\mathrm{cm})$. Horizontal lines indicate mean depth to water table $(\mathrm{cm})$ for each community. Note: ES, early summer (DOY 155-189); MS, mid-summer (DOY 190221); LS, late summer (DOY 222-255) for the 2014 measurement period. 78

Figure 4-16: Seasonal dissolved pore water $\mathrm{CH}_{4}$ concentrations $\left(\mu \mathrm{mol} \mathrm{L}{ }^{-1}\right)$ at $20,35,50$, 65 and $80 \mathrm{~cm}$ for Chamaedaphne, Ledum and Eriophorum-dominated communities at Mer Bleue during 2014. 80

Figure 4-17: Seasonal dissolved pore water $\mathrm{CH}_{4}$ concentrations $\left(\mu \mathrm{mol} \mathrm{L} \mathrm{L}^{-1}\right)$ at $50 \mathrm{~cm}$ depth for 3 Chamaedaphne-dominated autochambers (C-A 1, 2, 3) (circles), 3 Ledumdominated autochambers (L-A 1, 2, 3) (diamonds) and 3 Eriophorum-dominated manual chambers (E-M 1, 2, 3) (squares) at Mer Bleue during the 2014 measurement period. 81

Figure 4-18: Mean ( $\pm \mathrm{SD}) \delta^{13} \mathrm{C}-\mathrm{CH}_{4}$ isotopic signatures (\%o) for $\mathrm{CH}_{4}$ emitted from Chamaedaphne, Ledum and Eriophorum-dominated communities at Mer Bleue during the mid- to late-summer 2014 measurement period. 82

Figure 4-19: Mean $\mathrm{CH}_{4}$ storage change $\left(\mathrm{mg} \mathrm{m}^{-2} \mathrm{~h}^{-1}\right)$ for 3 Chamaedaphne-dominated autochambers (C-A 1, 2, 3), 3 Ledum-dominated autochambers (L-A 1, 2, 3) and 3 Eriophorum-dominated manual chambers (E-M 1, 2, 3) at the $50 \mathrm{~cm}$ depth $(15 \mathrm{~cm}$ thickness) during the pore water sampling period (DOY 155-255).

Figure 4-20: Relationship between mean storage change at $50 \mathrm{~cm}\left(\mathrm{mg} \mathrm{m}^{-2} \mathrm{~h}^{-1}\right)$ and mean $\mathrm{CH}_{4}$ flux $\left(\mathrm{mg} \mathrm{m}^{-2} \mathrm{~h}^{-1}\right)$ for 3 Chamaedaphne-dominated autochambers (C-A 1, 2, 3) (circles), 3 Ledum-dominated autochambers (L-A 1, 2, 3) (diamonds) and 3 Eriophorum-dominated manual chambers (E-M 1, 2, 3) (squares) at Mer Bleue for manual sampling days during the pore water collection period 2014 (DOY 155-255). 
The solid black line shows the nonlinear regression calculated to predict mean $\mathrm{CH}_{4}$ flux based on storage change at $50 \mathrm{~cm}$, where predicted mean $\mathrm{CH}_{4}$ flux $\left(\mathrm{mg} \mathrm{m}^{-2} \mathrm{~h}^{-1}\right)$ is equal to $9.08 \times 0.03^{\wedge} \mathrm{S}_{\mathrm{CH} 4}$ where $\mathrm{S}_{\mathrm{CH} 4}$ is storage change measured in $\mathrm{mg} \mathrm{m}^{-2} \mathrm{~h}^{-1} . .85$

Figure 4-21: Principal component analysis for averaged chamber-specific variables between DOY 212 and 255. $\mathrm{N}=9$. All pore water and temperature variables are from the $50 \mathrm{~cm}$ depth. Variables include: community type, total green hits LAI (LAI), percent LAI attributed to Eriophorum vaginatum (EV \%), total biomass LAI as measured with the LAI-2000 (LAI2000), $\mathrm{CH}_{4}$ flux $\left(\mathrm{F}_{\mathrm{CH} 4}\right)$, storage change of pore water $\mathrm{CH}_{4}\left(\mathrm{~S}_{\mathrm{CH}}\right)$, pore water $\mathrm{CH}_{4}$ concentration $\left(\mathrm{PW}_{\mathrm{CH} 4}\right), \delta^{13} \mathrm{C}-\mathrm{CH}_{4}$ source signature $\left(\delta^{13} \mathrm{C}-\mathrm{CH}_{4}\right)$, water table depth (WT), dissolved organic carbon (DOC), total dissolved nitrogen (TDN), carbon to nitrogen ratio (CN), absorbance at $254 \mathrm{~nm}$ $\left(\mathrm{Abs}_{254}\right)$, and specific ultraviolet absorbance at $254 \mathrm{~nm}\left(\mathrm{SUVA}_{254}\right)$. Chambers are dots and grouped according to community type: Chamaedaphne = blue, Ledum = green, and Eriophorum $=$ red. 


\section{LIST OF SYMBOLS AND ABBREVIATIONS}

\begin{tabular}{|c|c|c|}
\hline Symbol & Units & Definition \\
\hline$A$ & $\mathrm{~m}^{2}$ & chamber surface area \\
\hline$A b_{254}$ & $\mathrm{~m}^{-1}$ & absorbance at $254 \mathrm{~nm}$ \\
\hline$c_{a}$ & $\mu \mathrm{mol} \mathrm{mol}{ }^{-1}$ & ecosystem atmospheric $\mathrm{CH}_{4}$ concentration \\
\hline$c_{b}$ & $\mu \mathrm{mol} \mathrm{mol}{ }^{-1}$ & background $\mathrm{CH}_{4}$ concentration \\
\hline$c_{s}$ & $\mu \mathrm{mol} \mathrm{mol}{ }^{-1}$ & source $\mathrm{CH}_{4}$ concentration \\
\hline$C$ & & carbon \\
\hline$C-A$ & & Chamaedaphne automatic chamber \\
\hline $\mathrm{CH}_{4}$ & & methane \\
\hline $\mathrm{CO}_{2}$ & & carbon dioxide \\
\hline$C / N$ & & carbon to nitrogen ratio \\
\hline$C R D S$ & & cavity ring-down spectroscopy \\
\hline$\delta^{13} C_{a}$ & $\%$ & isotopic composition of the sampled $\mathrm{CH}_{4}$ \\
\hline$\delta^{13} C_{b}$ & $\%$ & isotopic composition of the background $\mathrm{CH}_{4}$ \\
\hline$\delta^{13} C_{s}$ & $\%$ & isotopic composition of the $\mathrm{CH}_{4}$ source component \\
\hline$\delta^{13} \mathrm{C}-\mathrm{CH}_{4}$ & $\%$ & $\begin{array}{l}\text { ratio of }{ }^{13} \mathrm{CH}_{4} \text { to }{ }^{12} \mathrm{CH}_{4} \text { relative to V-PDB marine } \\
\text { carbonate standard }\end{array}$ \\
\hline$d C / d t$ & $\begin{array}{c}\mu \mathrm{mol} \mathrm{mol}{ }^{-1} \\
\text { dry air s }{ }^{-1}\end{array}$ & rate of change in $\mathrm{CH}_{4}$ mixing ratio \\
\hline$\overline{D O C}$ & $m g L^{-1}$ & dissolved organic carbon \\
\hline$\overline{D O Y}$ & & day of year \\
\hline$E-M$ & & Eriophorum manual chamber \\
\hline$E S$ & & early summer (DOY 155-189) \\
\hline$E V$ & & Eriophorum vaginatum \\
\hline
\end{tabular}




\begin{tabular}{|c|c|c|}
\hline$E V \%$ & $\%$ & \% LAI attributed to Eriophorum vaginatum \\
\hline$F_{C H 4}$ & $m g m^{-2} h^{-1}$ & $\mathrm{CH}_{4}$ flux \\
\hline $\mathrm{H}_{2}$ & & hydrogen \\
\hline$L-A$ & & Ledum automatic chamber \\
\hline$L A I$ & $\mathrm{~m}^{2} \mathrm{~m}^{-2}$ & leaf area index \\
\hline$L A I-2000$ & $\mathrm{~m}^{2} \mathrm{~m}^{-2}$ & total biomass LAI as measured with LAI-2000 \\
\hline$L S$ & & late summer (DOY 222-255) \\
\hline$L S p$ & & late spring (DOY 132-154) \\
\hline$M S$ & & mid-summer (DOY 190-221) \\
\hline$N$ & & nitrogen \\
\hline NEE & $\mu \mathrm{mol} \mathrm{m} \mathrm{m}^{-2} \mathrm{~s}^{-1}$ & net ecosystem exchange of $\mathrm{CO}_{2}$ \\
\hline$\overline{\mathrm{O}_{2}}$ & & oxygen \\
\hline$O M$ & & organic matter \\
\hline$\rho$ & $\mathrm{Pa}$ & air pressure \\
\hline$P V C$ & & polyvinyl chloride \\
\hline$P W_{C H 4}$ & $\mu \mathrm{mol} \mathrm{L}{ }^{-1}$ & pore water $\mathrm{CH}_{4}$ concentration \\
\hline$R^{*}$ & $8.314 \mathrm{~J} \mathrm{~K}^{-1} \mathrm{~mol}^{-1}$ & ideal gas constant \\
\hline sccm & $\mathrm{sccm}$ & standard cubic centimeter per minute \\
\hline$S_{C H 4}$ & $m g m^{-2} h^{-1}$ & storage change of pore water $\mathrm{CH}_{4}$ \\
\hline$S U V A_{254}$ & $\mathrm{~L} \mathrm{~m}^{-1} \mathrm{mg}^{-1} \mathrm{DOC}$ & UV absorbance at $254 \mathrm{~nm}$ standardized to DOC \\
\hline$T_{\text {air }}$ & ${ }^{\circ} \mathrm{C}$ & air temperature measured at tower site \\
\hline$T_{\text {tower }}$ & ${ }^{\circ} \mathrm{C}$ & peat temperature measured at tower site \\
\hline$T_{10 \mathrm{~cm}}$ & ${ }^{\circ} \mathrm{C}$ & peat temperature at $10 \mathrm{~cm}$ depth (chamber-specific) \\
\hline$T_{50 \mathrm{~cm}}$ & ${ }^{\circ} \mathrm{C}$ & peat temperature at $50 \mathrm{~cm}$ depth at tower location \\
\hline$T D N$ & $\mathrm{mg} \mathrm{L}^{-1}$ & total dissolved nitrogen \\
\hline
\end{tabular}




\begin{tabular}{ccl}
\hline$T g$ & $10^{12} \mathrm{~g}$ & teragram \\
\hline$V$ & $\mathrm{~m}^{3}$ & chamber volume \\
\hline$W T$ & $\mathrm{~cm}$ & water table \\
\hline
\end{tabular}




\section{LIST OF APPENDICES}

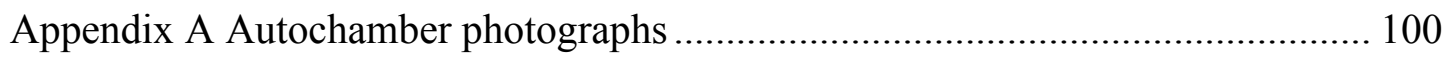

Appendix B Calculating concentrations of pore water constituents.......................... 103

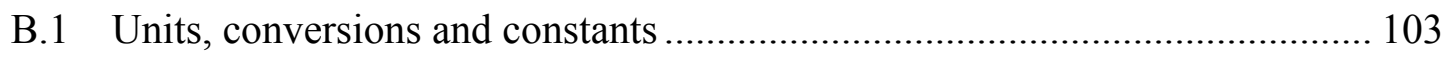

B.2 Calculating $\mathrm{CO}_{2}$ concentration in pore water............................................... 105

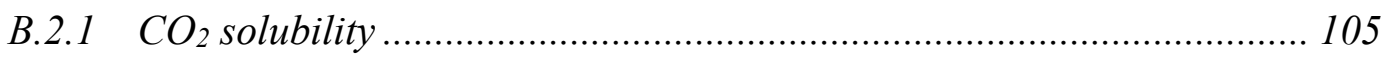

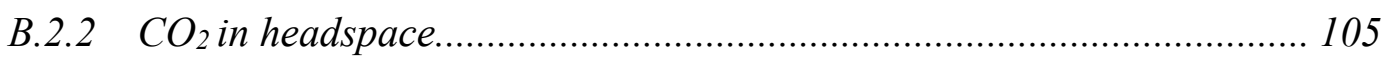

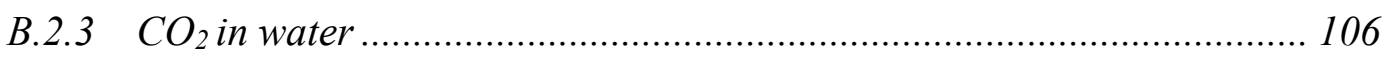

B.2.4 Total $\mathrm{CO}_{2}$ concentration in pore water ………................................... 106

B.2.5 Sample $\mathrm{CO}_{2}$ pore water concentration calculations ............................. 106

B.3 Calculating $\mathrm{CH}_{4}$ concentration in pore water................................................. 107

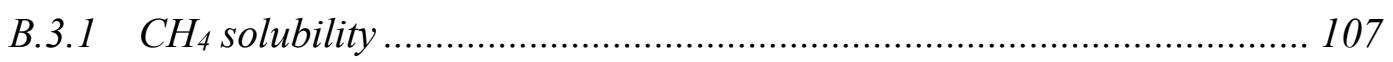

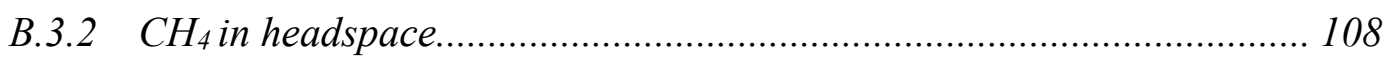

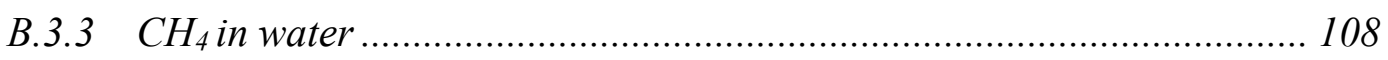

B.3.4 Total $\mathrm{CH}_{4}$ concentration in pore water .............................................. 109

B.3.5 Sample $\mathrm{CH}_{4}$ pore water concentration calculations ................................ 109

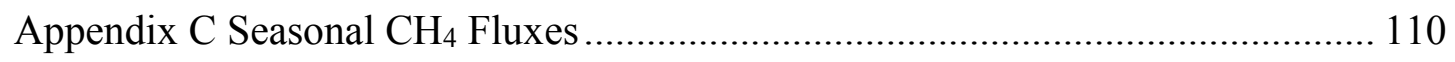

C.1 Comparison of $\mathrm{CH}_{4}$ fluxes among seasons................................................. 110

Appendix D Repeated measures analysis using mixed models in JMP ................... 113

D.1 Mixed model analysis of factors affecting $\mathrm{CH}_{4}$ fluxes ...................................... 113

D.2 Mixed model analysis of factors affecting pore water $\mathrm{CH}_{4}$ concentrations ...... 115

D.3 Mixed model analysis of factors affecting $\delta^{13} \mathrm{C}^{-} \mathrm{CH}_{4}$ source signatures ........... 119 


\subsection{INTRODUCTION}

Wetlands have been identified as particularly important ecosystems for global carbon (C) dynamics (Bridgham et al. 2006). In particular, northern peatland ecosystems have sequestered 76-96 $\mathrm{Tg} \mathrm{C} \mathrm{a}^{-1}$ through the uptake of carbon dioxide $\left(\mathrm{CO}_{2}\right)$ over the long term (Gorham 1991, Gorham 1995). However, they also emit approximately $38 \mathrm{Tg}$ methane $\left(\mathrm{CH}_{4}\right) \mathrm{a}^{-1}$, which has a higher potential for climate forcing over the short term in comparison to $\mathrm{CO}_{2}$ (Bartlett \& Harriss 1993). Considering the variable atmospheric growth rate over the past 3 decades, including a recent increase in the growth rate of $\mathrm{CH}_{4}$ concentrations since 2007 (Kirschke et al. 2013), there is a current need to examine the potential feedbacks and responses of peatland $\mathrm{CH}_{4}$ emissions to climate change.

Atmospheric $\mathrm{CH}_{4}$ depends on a number of sources and sinks, with wetland emissions of $\mathrm{CH}_{4}$ representing the largest natural emitter. Increased understanding of the processes that lead to $\mathrm{CH}_{4}$ loss in wetlands such as peatlands is crucial for the development of a global $\mathrm{CH}_{4}$ budget that accurately captures $\mathrm{CH}_{4}$ source and sink estimates (Mikaloff Fletcher et al. 2004a, Chanton et al. 2005, Kirschke et al. 2013).

Climate change projections indicate a multitude of possible responses by northern peatlands (Bridgham et al. 2013). For example, vascular plants (especially deciduous shrubs and graminoids) are expected to dominate over mosses and lichens as temperatures and growing season length increases (Walker et al. 2006, IPCC 2007, Gallego-Sala \& Prentice 2013). The composition of the peatland plant community, which reflects environmental variables such as nutrient availability and long-term water table (WT) depths, is often used as an indicator of the potential magnitude of $\mathrm{CH}_{4}$ emissions among and within peatlands. The dominant vegetative communities of northern peatlands 
also directly impact $\mathrm{CH}_{4}$ exchange by influencing substrate availability for methaneproducing microorganisms and gas transport above and below the WT via aerenchymatous tissues (Couwenberg et al. 2011, Bridgham et al. 2013, Ward et al. 2013).

While vegetative community has been identified as an important ecosystem response indicator, there remains a need for increased understanding of the complex relation between plant community composition and $\mathrm{CH}_{4}$ emission. This study seeks to couple the use of autochamber $\mathrm{CH}_{4}$ flux measurements with pore water and stable carbon isotope analyses to achieve a better understanding of $\mathrm{CH}_{4}$ production, storage and transport pathways for different vegetative communities along depth profiles at a temperate ombrotrophic bog. This will aid in determining the relative importance of dominant environmental controls, including vegetation type, on $\mathrm{CH}_{4}$ emission dynamics.

Three key research hypotheses follow from this central research aim:

1. Spatial and temporal variability in $\mathrm{CH}_{4}$ emissions will vary with plant community characteristics, where sedge-dominated plots are expected to have greater emissions than plots dominated by hummock species. This hypothesis follows findings by Lai et al. (2014a) and is based on the notion that $\mathrm{CH}_{4}$ production, storage and transport will all be impacted by the abiotic and biotic variables that are associated with the different plant community types. These include, for example, the average WT depth and the presence of vegetation with aerenchymatous tissues. 
2. As the growing season progresses, increasing peat temperature and plant growth will be associated with changes in belowground pore water characteristics that suggest increased substrate availability and increased $\mathrm{CH}_{4}$ production rates, especially with reducing conditions in the saturated zone at a depth close to the long-term average WT. This hypothesis is based on previous laboratory studies that have identified these environmental factors as important controls on methanogenic metabolism (Dunfield et al. 1993, Moore \& Dalva 1993, Yavitt \& Seidman-Zager 2006).

3. The seasonal increase in $\mathrm{CH}_{4}$ storage will be lowest at chamber plots that are associated with the highest seasonal $\mathrm{CH}_{4}$ emissions, as these emissions represent a loss of stored $\mathrm{CH}_{4}$ from peat. This follows previous evidence of a decoupling between $\mathrm{CH}_{4}$ production and emission to the atmosphere due to transport limitations (i.e. diffusive transport of $\mathrm{CH}_{4}$ dominates over plant-mediated transport) (Moore \& Dalva 1993, Blodau 2002, Brown et al. 2014). 


\subsection{BACKGROUND}

\subsection{Northern peatlands and climate}

According to a digital, high-resolution database of wetland sites developed by Matthews \& Fung (1987), wetlands were historically estimated to cover a global area of approximately $5.3 \times 10^{12} \mathrm{~m}^{2}$ or roughly $3.6 \%$ of the global terrestrial surface. More recent wetland inventory analyses suggest this estimate may be up to 2 times greater (Bridgham et al. 2013). The total northern wetland area used in global $\mathrm{CH}_{4}$ emission studies varies widely from $2.6 \times 10^{12}$ to $9.0 \times 10^{12} \mathrm{~m}^{2}$ (Petrescu et al. 2010$)$ and is a major source of uncertainty when assessing the global $\mathrm{CH}_{4}$ budget (Kirschke et al. 2013). While the distribution of these wetlands tends to be scattered and the areas small, they represent an important component in the global C cycle (Matthews \& Fung 1987, Bridgham et al. 2013). Among these wetlands are northern peatlands where organic matter (OM) has accumulated as peat to a depth of $40 \mathrm{~cm}$ or more (Gorham 1995). These northern peatland ecosystems cover an area of approximately $3.5 \times 10^{12} \mathrm{~m}^{2}$ and have a mean peat depth of $\sim 2.3 \mathrm{~m}$ (Gorham 1991). They are estimated to contain between 273 and $455 \times$ $10^{15} \mathrm{~g}$ of C, $98.5 \%$ of which is in the form of peat (Gorham 1991, Turunen et al. 2002). This large range in $\mathrm{C}$ storage estimation is attributed to uncertainty surrounding global peat depths and area (Gorham 1991).

Northern peatlands are currently or have been net sinks for $\mathrm{C}$ because net primary production (i.e. photosynthetic uptake of carbon dioxide, $\mathrm{CO}_{2}$ ) occurs at a greater rate than the decomposition of OM, resulting in the accumulation of peat (Gorham 1991, Gorham 1995, Moore et al. 1998). However, the persistent oxygen $\left(\mathrm{O}_{2}\right)$-depleted 
conditions in wetlands are also favourable for the production of $\mathrm{CH}_{4}$, with natural wetlands representing the largest natural $\mathrm{CH}_{4}$ source and contributing $\sim 30 \%$ of global $\mathrm{CH}_{4}$ emissions (Bridgham et al. 2013, Kirschke et al. 2013). Bartlett \& Harriss (1993) estimated that wetlands north of $45^{\circ} \mathrm{N}$ release up to $38 \mathrm{Tg} \mathrm{CH}_{4} \mathrm{a}^{-1}$ while globally, wetlands may emit 55 to $231 \mathrm{Tg} \mathrm{CH}_{4} \mathrm{a}^{-1}$ (Houweling et al. 2000, Wuebbles \& Hayhoe 2002, Neef et al. 2010). For northern peatlands, the global long-term rate of net atmospheric $\mathrm{CO}_{2}$ sequestration ranges from $76-96 \mathrm{Tg} \mathrm{C} \mathrm{a}^{-1}$ over the past 4600 years (Gorham 1991, Gorham 1995). At individual site level, the mean 6-year $\mathrm{CO}_{2}$ exchange at

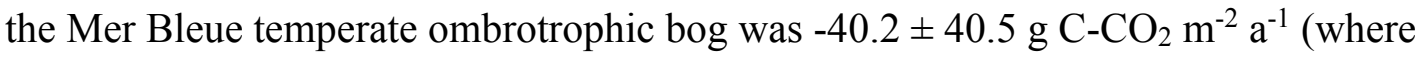
negative values indicate a net uptake by the peatland), while $\mathrm{CH}_{4}$ exchange and dissolved organic C (DOC) export were $3.7 \pm 0.5 \mathrm{~g} \mathrm{C}^{-} \mathrm{CH}_{4} \mathrm{~m}^{-2} \mathrm{a}^{-1}$ and $14.9 \pm 3.1 \mathrm{~g} \mathrm{C}-\mathrm{DOC} \mathrm{m}^{-2} \mathrm{a}^{-1}$ respectively. While the $\mathrm{CH}_{4}$ exchange component at Mer Bleue is small in comparison to DOC export, many peatlands have a seasonal $\mathrm{CH}_{4}$ flux value in the same range as DOC loss (Roulet et al. 2007). However, while characterized by significant spatial and temporal variability, $\mathrm{CO}_{2}$ uptake usually offsets $\mathrm{CH}_{4}$ emissions in the long-term (i.e. several centuries) in wetlands (Petrescu et al. 2015). For example, at the Stordalen palsa mire complex in subarctic Sweden, average annual $\mathrm{CH}_{4}$ emissions were 18-22 g C-CH 4 $\mathrm{m}^{-2}$ while annual $\mathrm{CO}_{2}$ uptake was $46 \mathrm{~g} \mathrm{C}-\mathrm{CO}_{2} \mathrm{~m}^{-2}$ over 8 years (2001-2008) of micrometeorological monitoring (Christensen et al. 2012). At the Degerö Stormyr boreal minerogenic oligotrophic mire complex in northern Sweden, annual $\mathrm{CH}_{4}$ emissions and

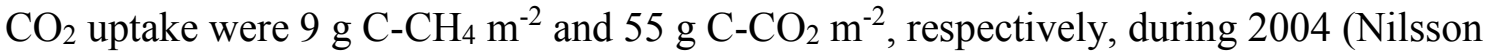
et al. 2008). Methane emissions from the western peatland flux station northeast of

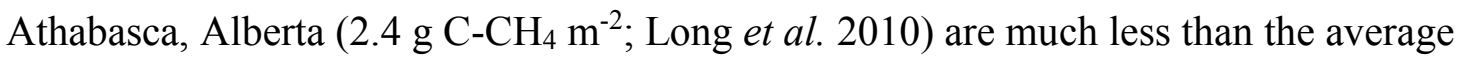


annual uptake of $\mathrm{CO}_{2}$ of $144 \mathrm{~g} \mathrm{C}-\mathrm{CO}_{2} \mathrm{~m}^{-2}$ (Syed et al. 2006). At a fen area with continuous permafrost in northeastern Greenland, $\mathrm{CH}_{4}$ emissions were also less than $\mathrm{CO}_{2}$ uptake (2.8 g C-CH $4 \mathrm{~m}^{-2}$ vs. 48.7 g C-CO $\mathrm{CO}_{2}^{-2}$, over 87 and 62 days respectively; Friborg et al. 2000, Soegaard et al. 2000). Although $\mathrm{CH}_{4}$ emissions may be much less than $\mathrm{CO}_{2}$ sequestration and $\mathrm{CH}_{4}$ is short-lived in the atmosphere, it is more effective at absorbing incoming infrared radiation and is thus a more potent greenhouse gas than $\mathrm{CO}_{2}($ Bartlett \& Harriss 1993). According to the Intergovernmental Panel on Climate Change (2013), $\mathrm{CH}_{4}$ has 86 times the relative cumulative forcing index as $\mathrm{CO}_{2}$ on a mass basis over a 20year period. Although characterized by large inter-annual variability, growth of $\mathrm{CH}_{4}$ concentrations in the atmosphere slowed and stabilized during the mid-1990's, remaining relatively constant until 2006 (Bridgham et al. 2013). Since 2007, however, atmospheric $\mathrm{CH}_{4}$ concentrations have been on the rise with an average atmospheric concentration of $1.80 \mathrm{ppm}$ in 2010 (Kirschke et al. 2013). The variable atmospheric growth rate of $\mathrm{CH}_{4}$ over recent decades signals a need for increased understanding of the factors influencing natural peatland $\mathrm{CH}_{4}$ emissions. Yet, the controls over $\mathrm{CH}_{4}$ production, consumption and transport are poorly represented in current $\mathrm{CH}_{4}$ biogeochemistry models, largely due to a limited number of $\mathrm{CH}_{4}$ flux datasets with which these models may be improved and validated (Bridgham et al. 2013, Kirschke et al. 2013).

Peatlands are often neglected in global climate change models despite their importance for global C cycling, as there exist large uncertainties surrounding wetland controls on C fluxes, such as wetland specific plant functional types (Moore et al. 1998, IPCC 2013). Dissolved organic carbon (DOC) export, $\mathrm{CO}_{2}$ exchange, $\mathrm{CH}_{4}$ exchange, and $\mathrm{C}$ storage constitute the major components of peatland $\mathrm{C}$ cycles and are primarily 
controlled by air and substrate temperature, $\mathrm{pH}$, plant community structure, substrate availability/quality and reduction/oxidation (i.e. redox) boundaries associated with WT position (Moore et al. 1998, Blodau 2001).

\subsection{1 $\mathrm{CH}_{4}$ production}

According to Klass (1984), biogenic $\mathrm{CH}_{4}$ production requires modest temperatures, ambient pressures, fully saturated conditions and the absence of other freeenergy electron acceptors (e.g. $\mathrm{O}_{2}$, nitrate, sulphate). The production of $\mathrm{CH}_{4}$ is directly dependent on microbial activity, thus an organic $\mathrm{C}$ substrate and mixed population of $\mathrm{CH}_{4}$-producing microorganisms (i.e. methanogens) is also necessary (Klass 1984, Clark \& Fritz 1997). This organic C substrate serves as a food source to support methanogens, which require small, simple dissolved organic molecules with molecular weights $<600 \mathrm{~g}$ mol $^{-1}$ (Fenchel et al. 1998, Blodau 2001). These molecules are produced when fermentive bacteria reduce complex organic molecules in the peat to simpler molecules like fatty acids, which are then transformed by acetogenic bacteria to acetate with $\mathrm{CO}_{2}$ and hydrogen $\left(\mathrm{H}_{2}\right)$ as byproducts (Equation 1). Organic-rich environments thus facilitate reactant supply (i.e. acetate, $\mathrm{H}_{2}$ and $\mathrm{CO}_{2}$ ) for methanogenic pathways (Clark \& Fritz 1997).

$$
\mathrm{CH}_{3} \mathrm{CH}_{2} \mathrm{COOH}+2 \mathrm{H}_{2} \mathrm{O} \rightarrow \mathrm{CH}_{3} \mathrm{COOH}+\mathrm{CO}_{2}+3 \mathrm{H}_{2}
$$

Recent ${ }^{14} \mathrm{C}$-labelling studies suggest that root exudates (i.e. plant photosynthate) serve as organic $\mathrm{C}$ substrate for $\mathrm{CH}_{4}$ production in the rhizosphere. These root exudates also indirectly increase $\mathrm{CH}_{4}$ production through priming effects, where they trigger the 
decomposition of less labile soil OM (Bridgham et al. 2013). Additionally, methanogens require mineral nutrients, a reducing agent and a source of nitrogen (i.e. $\mathrm{NH}_{4}^{+}$). As obligate anaerobes, methanogens cannot tolerate $\mathrm{O}_{2}$ and are most active under strongly reducing conditions of less than $-200 \mathrm{mV}$ as demonstrated in Table 2-1 (Zhi-Guang 1985, Mansfeldt 2003, Vorenhout et al. 2004).

Table 2-1: Redox pairs and redox values (Eh) at transformation at reference $\mathrm{pH}$ of 7.0 (Adapted from Vorenhout et al. 2004)

\begin{tabular}{l|lll}
\hline & Oxidized form & Reduced form & Eh at transformation $(\mathrm{mV})$ \\
\hline Oxygen & $\mathrm{O}_{2}$ & $\mathrm{H}_{2} \mathrm{O}$ & +600 to +400 \\
Nitrogen & $\mathrm{NO}_{3}{ }^{-}$ & $\mathrm{N}_{2} \mathrm{O}, \mathrm{N}_{2}, \mathrm{NH}_{4}{ }^{+}$ & 250 \\
Manganese & $\mathrm{Mn}^{4+}$ & $\mathrm{Mn}^{2+}$ & 225 \\
Iron & $\mathrm{Fe}^{3+}$ & $\mathrm{Fe}^{2+}$ & +100 to -100 \\
Sulfur & $\mathrm{SO}_{4}{ }^{2-}$ & $\mathrm{S}^{2-}$ & -100 to -200 \\
Carbon & $\mathrm{CO}_{2}$ & $\mathrm{CH}_{4}$ & $<-200$ \\
\hline
\end{tabular}

An understanding of the $\mathrm{CH}_{4}$ production pathways remains limited (Galand et al. 2010). It has been established that the decomposition of OM by a form of anaerobic respiration in methanogenic Archea produces $\mathrm{CH}_{4}$ as an ultimate end product (Conrad 2005). Methane is primarily produced in the upper portion of saturated peat and/or sedimentary environments, where $\mathrm{O}_{2}$ is absent, yet methanogens still have access to sufficient organic substrate (Chanton et al. 2005). The two main $\mathrm{CH}_{4}$ production pathways in terrestrial freshwater systems include acetoclastic methanogenesis (Equation 2) and hydrogenotrophic methanogenesis (Equation 3) (Chanton et al. 2005). 


$$
\mathrm{CH}_{3} \mathrm{COOH} \rightarrow \mathrm{CH}_{4}+\mathrm{CO}_{2}
$$

$$
\mathrm{CO}_{2}+4 \mathrm{H}_{2} \rightarrow \mathrm{CH}_{4}+2 \mathrm{H}_{2} \mathrm{O}
$$

The fermentation of acetate (acetoclastic methanogenesis, Equation 2) occurs when acetic acid $\left(\mathrm{CH}_{3} \mathrm{COOH}\right)$ acts as the terminal electron acceptor (i.e. food source) resulting in the production of $\mathrm{CH}_{4}$ and $\mathrm{CO}_{2}$ gas (Clark \& Fritz 1997). While acetoclastic methanogenesis can play an important role in both ombrotrophic and minerotrophic peatlands, only a few species of methanogens can use acetate as a substrate (Avery et al. 1999, Kotsyurbenko et al. 2004, Kotsyurbenko et al. 2007, Galand et al. 2010). Thus, $\mathrm{CO}_{2}$ reduction with $\mathrm{H}_{2}$ gas to form $\mathrm{CH}_{4}$ (hydrogenotrophic methanogenesis, Equation 3) is typically viewed as the dominant pathway of peatland $\mathrm{CH}_{4}$ production. The methanogens required for this process are thought to be present in differing levels of diversity in all peatlands (Kotsyurbenko et al. 2007). While these two mechanisms have been identified as the main drivers of methanogenesis in most environments, identifying their relative contributions and how each pathway is controlled by environmental factors remains a challenge (Conrad 2005, Kotsyurbenko et al. 2007,Galand et al. 2010). For example, freshwater wetlands seem to be heavily influenced by vegetation: Sphagnummoss-vegetated bogs produce $\mathrm{CH}_{4}$ mainly by $\mathrm{CO}_{2}$ reduction while fens dominated by Carex sedges rely on acetate fermentation (Chanton et al. 2005). Additionally, stable isotope measurements from pore water depth profiles obtained at two temperate wetlands show that the upper peat layers (rich in labile organic C) are favourable for acetoclastic methanogenesis, while $\mathrm{CO}_{2}$ reduction is increasingly important as peat becomes more recalcitrant with depth (Hornibrook et al. 1997). 


\subsection{2 $\mathrm{CH}_{4}$ consumption}

As the $\mathrm{CH}_{4}$ produced in the anaerobic saturated zone diffuses up through the aerobic peat layer along a concentration gradient, $\mathrm{CH}_{4}$-consuming microbes (i.e. methanotrophs) reoxidize $\mathrm{CH}_{4}$ to methanol $\left(\mathrm{CH}_{3} \mathrm{OH}\right)$, formaldehyde $\left(\mathrm{CH}_{2} \mathrm{O}\right)$, formate $\left(\mathrm{CHOO}^{-}\right)$then $\mathrm{CO}_{2}$ (Whalen 2005). The main $\mathrm{CH}_{4}$ consumption types include low and high affinity oxidation, which occur at high $(>40 \mathrm{ppm})$ and close to atmospheric $(<12$ ppm) $\mathrm{CH}_{4}$ concentrations respectively (Segers 1998, Le Mer \& Roger 2001). In northern peatlands, low affinity oxidation occurring at high $\mathrm{CH}_{4}$ concentrations is the dominant $\mathrm{CH}_{4}$ consumption process (Bender \& Conrad 1995). The $\mathrm{CH}_{4}$ is used as a $\mathrm{C}$ and energy source by methanotrophs (Le Mer \& Roger 2001). For $\mathrm{CH}_{4}$ oxidation to proceed, the presence of $\mathrm{O}_{2}$ is key as it acts as an electron acceptor for the formation of $\mathrm{CO}_{2}$. Oxidizing conditions $>400 \mathrm{mV}$ indicate the predominance of $\mathrm{O}_{2}$ in a substrate, and are thus associated with maximum methanotrophic activity (Zhi-Guang 1985, Mansfeldt 2003).

As sufficient $\mathrm{O}_{2}$ is present in the aerobic zone (i.e. above WT) and maximum $\mathrm{CH}_{4}$ substrate occurs in the anaerobic zone (i.e. below WT), there is some evidence that $\mathrm{CH}_{4}$ consumption peaks within $\sim 25 \mathrm{~cm}$ of the aerobic/anaerobic interface or average WT position before $\mathrm{CH}_{4}$ concentrations are too low to support methanotrophs (Segers 1998). Methanotrophs could potentially form hotspots of $\mathrm{CH}_{4}$ oxidation below the average WT position if sufficient $\mathrm{O}_{2}$ reaches these depths through plant transport. For example, $\mathrm{C}$ deprivation experiments have demonstrated that methanotrophic bacteria persist under anaerobic conditions, suggesting that methanotrophs can enter an anaerobic dormant state and significantly attenuate internal metabolism (Roslev \& King 1994, Roslev \& King 
1995). Thus, when aerenchymatous tissues transport sufficient $\mathrm{O}_{2}$ below the WT, methanotrophic activity can proceed through the oxidation of these high $\mathrm{CH}_{4}$ concentrations in the saturated zone.

\subsection{3 $\mathrm{CH}_{4}$ transport}

Molecular diffusion and ebullition (i.e. sudden release of $\mathrm{CH}_{4}$ bubbles) through the peat and diffusion through plant aerenchyma (i.e. soft plant tissue containing air spaces) comprise the three main pathways of $\mathrm{CH}_{4}$ emission to the atmosphere (Figure 2-1). The diffusion pathway is driven by a $\mathrm{CH}_{4}$ concentration gradient where $\mathrm{CH}_{4}$ concentrations decrease traveling up the peat profile from the zone of $\mathrm{CH}_{4}$ production (i.e. deeper anaerobic peat layers) to the atmosphere (Blodau et al. 2007, Dorodnikov et

al. 2013). While diffusive transport is the slowest of the three pathways (especially in the saturated anaerobic peat layers), it serves the important role of transporting $\mathrm{CH}_{4}$ through the aerobic upper peat layer where microbial $\mathrm{CH}_{4}$ consumption through oxidative processes can occur (Whalen 2005). 


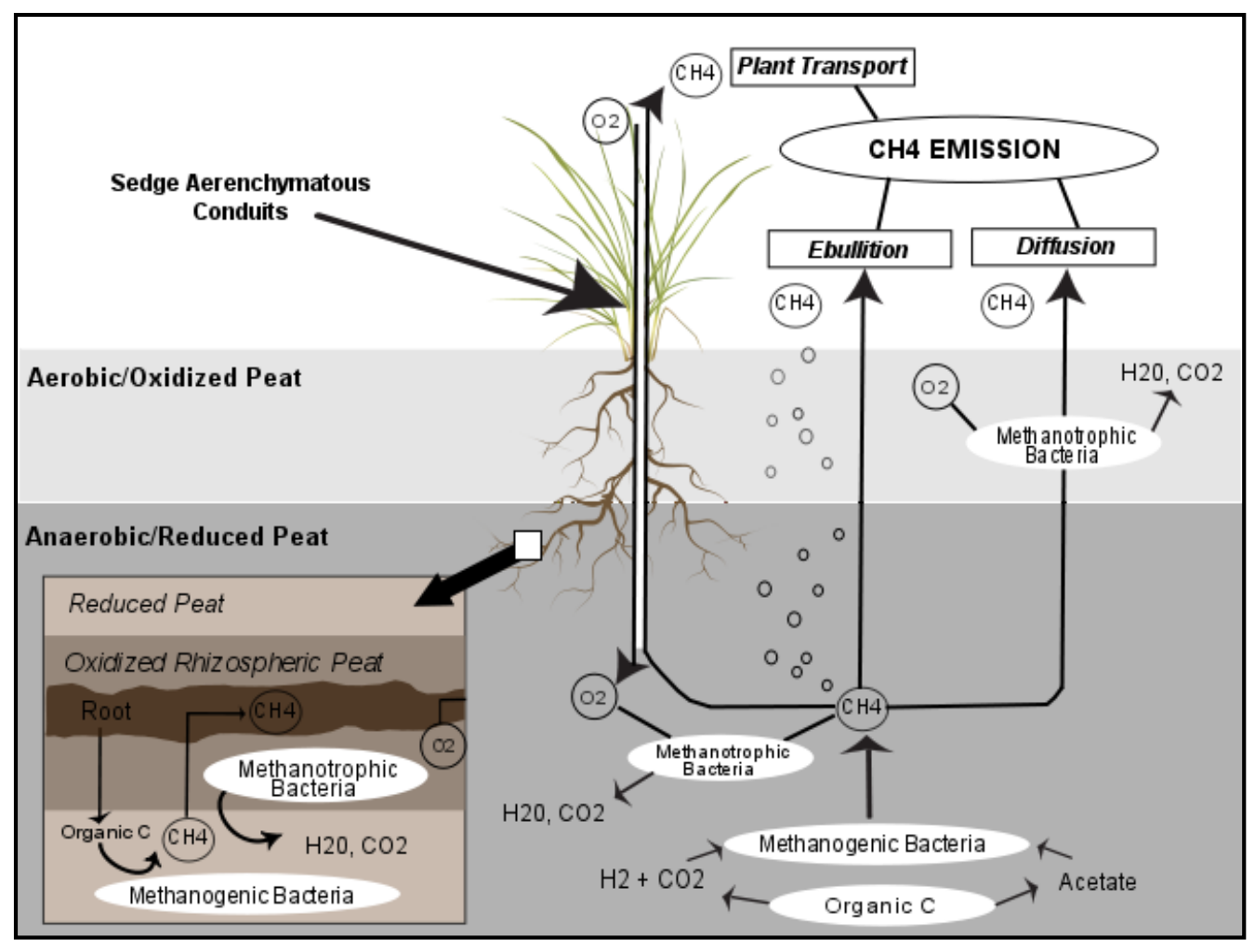

Figure 2-1: Methane production, consumption and transport pathways in peat layers (Adapted from Le Mer \& Roger 2001).

The atmospheric release of free-phase $\mathrm{CH}_{4}$ in gas bubbles, known as ebullition, can be episodic in nature where it is initiated by pore water $\mathrm{CH}_{4}$ supersaturation at depth (i.e. in anaerobic zone of $\mathrm{CH}_{4}$ production). Bubbles form when the hydrostatic pressure in peat is exceeded by the partial pressure of all dissolved gases in solution (Chanton \& Whiting 1995). These $\mathrm{CH}_{4}$ bubbles are not immediately released to the atmosphere; rather, the gas bubbles accumulate in peat pores until overpressure zones develop in peat and the bubbles move towards the peat surface (Kellner et al. 2004). Slow ebullition, where bubbles are released at a steady rate, typically results in a large proportion of bubble $\mathrm{CH}_{4}$ being consumed through oxidation in the peat column above the WT (Rosenberry et al. 2006). Episodic ebullition events, however, involve much higher rates of degassing. These sudden bubbling events can overwhelm $\mathrm{CH}_{4}$ oxidation potential by 
methanotrophs in the aerobic peat layer and release much greater volumes of $\mathrm{CH}_{4}$ than slow ebullition (Rosenberry et al. 2006). The rupture of a peat fabric/layer may create a preferential flow path thereby enabling such large volumes of gas release through episodic ebullition. For example, ebullition has been shown to release $40-53 \mathrm{~g} \mathrm{CH}_{4} \mathrm{~m}^{-2}$ per event at the Red Lake peatland, northern Minnesota (Glaser et al. 2004). Falling atmospheric pressure has also been associated with episodic ebullition events, with results by Tokida et al. (2007) indicating an increase in $\mathrm{CH}_{4}$ flux by 2 orders of magnitude over short time scales ( $<2$ hours). These large releases of $\mathrm{CH}_{4}$ significantly contribute to total $\mathrm{CH}_{4}$ flux in some northern peatlands (Tokida et al. 2007).

The third transport pathway is facilitated by the aerenchymatous tissues of some vascular peatland plants such as sedges, which function as conduits for $\mathrm{CH}_{4}$ gas transport from the roots to the atmosphere. Methane travels up through the aerenchyma as a result of molecular diffusion along the concentration gradient and bulk flow due to pressure differences between internal plant air spaces and the atmosphere (Lai 2009). While transport capabilities are species specific, this relatively fast pathway reduces the residence time of $\mathrm{CH}_{4}$ in the aerobic zone and thus limits $\mathrm{CH}_{4}$ oxidation potential in upper peat layers (Blodau 2001, Strack et al. 2006). Sedges in particular often have roots that reach below the WT depth, with sedge root biomass peaking close to $50 \mathrm{~cm}$ below peat surface and extending as deep as $1 \mathrm{~m}$ in a temperate bog where the average WT is $\sim 42 \mathrm{~cm}$ below the surface (Moore et al. 2002, Murphy \& Moore 2010). These roots add labile $\mathrm{C}$ and other substrates to the anaerobic zone (Strack et al. 2006). In the opposite direction, aerenchyma provide a conduit for the diffusion of atmospheric $\mathrm{O}_{2}$ to the rhizosphere below the aerobic/anaerobic boundary (i.e. radial oxygen loss), creating 
aerated volumes or oxic "pockets" where $\mathrm{CH}_{4}$ oxidation could occur at depth (Vasander \& Kettunen 2006). Thus, a larger sedge root biomass may cause increased $\mathrm{CH}_{4}$ consumption by enabling $\mathrm{O}_{2}$ transport and associated reoxidation of $\mathrm{CH}_{4}$ in the rhizosphere below the WT (Blodau 2001, Strack et al. 2006). However, there is some evidence suggesting that not all aerenchymatous plant species provide the opportunity for $\mathrm{CH}_{4}$ oxidation at depth. For example, Frenzel and Rudolph (1998) could not determine any significant $\mathrm{CH}_{4}$ oxidation at depth for Eriophorum species. They concluded that this species was associated with low $\mathrm{CH}_{4}$ oxidation rates and did not reduce $\mathrm{CH}_{4}$ emissions. This could result from plant influence on biogeochemistry at depth, where different species produce root exudates of varying type and quality (Frenzel \& Rudolph 1998).

\subsection{Environmental controls on peatland $\mathrm{CH}_{4}$ emissions}

\subsubsection{Redox boundary associated with WT position}

Methane emissions can vary spatially and temporally at fine scales as numerous interactive environmental factors affect biologically mediated $\mathrm{CH}_{4}$ emissions from soils (Bartlett \& Harriss 1993, Blodau 2001, Chanton et al. 2005). The microtopography of peatlands is typically divided into horizontal microstructure levels that have characteristic WT positions and vegetative communities (Strack et al. 2008, Rydin \& Jeglum 2013). For example, hummock-hollow microtopography is common in ombrotrophic bogs. Hummocks are characterized by dwarf shrubs and tend to be $20-50 \mathrm{~cm}$ above the lowest surface level (Rydin \& Jeglum 2013). Hollows refer to the depressions between hummocks, which can be a combination of lawns, carpets and mud-bottoms where graminoids and/or mosses dominate and the WT is closer to the peat surface (Rydin \& 
Jeglum 2013). The microtopographic differences in vegetative community and associated depth to WT influence $\mathrm{CH}_{4}$ dynamics and contribute to its spatial variability. These processes are also governed by the vertical structuring of peatlands, which is intricately linked with WT position. Aerobic conditions (presence of $\mathrm{O}_{2}$ ) occur above the WT in the acrotelm or unsaturated upper peat layer (top $\sim 5-40 \mathrm{~cm}$ ). Beneath this layer, the catotelm is characterized by saturated, anaerobic conditions (depletion of $\left.\mathrm{O}_{2}\right)($ Rydin \& Jeglum 2013).

The boundary between aerobic and anaerobic conditions shifts according to the position of the WT, inducing both biotic and abiotic changes (Limpens et al. 2008, Rydin \& Jeglum 2013). Such changes could include alterations in dominant vegetation types. For example, Bubier et al. (2006) found that WT, in conjunction with water chemistry, was an important control on vegetation distribution at Mer Bleue, a temperate bog. Their results showed that most dominant ericaceous shrubs, including Vaccinium myrtilloides, Ledum groenlandicum and Chamaedaphne calyculata, favoured drier microtopographic positions while Kalmia angustifolia and Eriophorum vaginatum had higher biomass with WT closer to the peat surface (Bubier et al. 2006). Shifts in WT position could also induce variations in decomposition rates and processes (Rydin \& Jeglum 2013). This hydrological control (i.e. WT position) defines the boundary between reduction and oxidation zones in the soil profile and is thus identified as a critical factor for $\mathrm{CH}_{4}$ production in many $\mathrm{CH}_{4}$ flux studies within peatlands (e.g. Turetsky et al. 2008, Lai et al. 2014a, Lai et al. 2014b) and among peatlands (e.g. Turetsky et al. 2014). Theoretically, a WT closer to the peat surface would result in larger $\mathrm{CH}_{4}$ emissions as the saturated $\mathrm{CH}_{4}$ production zone increases while the unsaturated $\mathrm{CH}_{4}$ consumption zone shrinks. For 
example, Turetsky et al. (2008) manipulated WT position at an ecosystem-scale in an Alaskan peatland and found that a raised WT resulted in the largest $\mathrm{CH}_{4}$ fluxes. However, a study at a poor fen site demonstrated that a lowered WT led to increased biomass in hollows and $\mathrm{CH}_{4}$ fluxes remained relatively high despite the thicker aerobic peat layer (Strack et al. 2008). This suggests that increased biomass could offset lowered WT effects through substrate addition and enhanced plant-mediated $\mathrm{CH}_{4}$ transport at peatland hollows over a time scale of 2-5 years, highlighting the importance of climate change feedbacks in relation to vegetation and WT position (Strack et al. 2008).

At short time scales (i.e. weeks to months), the interaction between $\mathrm{CH}_{4}$ production, consumption and transport processes may not be at equilibrium with varying environmental controls, such as WT position (Blodau 2002). It has been suggested that rates of $\mathrm{CH}_{4}$ production in peat are decoupled from atmospheric fluxes to some extent (Blodau 2002). Changes in storage of $\mathrm{CH}_{4}$ within the peat pore water would result. For example, Moore et al. (1990) observed large negative changes in stored $\mathrm{CH}_{4}$ in peat pore water $(260$ to $<90 \mu \mathrm{mol} \mathrm{L}-1)$ corresponding with increased $\mathrm{CH}_{4}$ fluxes in subarctic/northern boreal fens. The largest mean daily $\mathrm{CH}_{4}$ flux $\left(262 \pm 205 \mathrm{mg} \mathrm{m}^{-2} \mathrm{~d}^{-1}\right)$ on August 12, 1989, released 3-4 $\mathrm{g} \mathrm{CH}_{4} \mathrm{~m}^{-2}$ from storage (Moore et al. 1990). Also, $\mathrm{CH}_{4}$ production itself may not respond immediately to driving variables. Results from peat incubations have provided evidence for a time lag between the onset of saturated conditions and the initiation of $\mathrm{CH}_{4}$ production processes (Öquist \& Sundh 1998). Kettunen et al. (1999) found that a 1-week period of aerobic conditions followed by resaturation of the peat profile produced low $\mathrm{CH}_{4}$ fluxes due to a time lag between rising WT (i.e. re-saturation) and reactivation of $\mathrm{CH}_{4}$ production processes. Similar results were 
previously demonstrated through laboratory peat column experiments, where $\mathrm{CH}_{4}$ emission rates did not reach significant levels until up to 10 days after the WT was raised to the surface of the column (Moore \& Dalva 1993). Knorr et al. (2008) observed that draining (i.e. experimental drought) followed by rewetting delayed $\mathrm{CH}_{4}$ production in temperate peat by weeks to months. Recent results indicate that dropping WT levels can reoxidize terminal electron acceptors in peat, thus suppressing $\mathrm{CH}_{4}$ production processes after WT is raised until more favourable terminal electron acceptors have been consumed (Deppe et al. 2010b). The result is hysteresis in the relationship between $\mathrm{CH}_{4}$ emissions and WT (Blodau \& Moore 2003). The zone of WT fluctuation in particular exhibits a memory for $\mathrm{CH}_{4}$ production rates based on past conditions. The history at a particular depth location thus affects $\mathrm{CH}_{4}$ production rates when saturated anaerobic conditions commence (Blodau 2002).

\subsubsection{Organic substrate supply}

Once the peat is saturated, $\mathrm{CH}_{4}$ production becomes limited by the availability of organic substrate (Segers 1998). The compounds that comprise DOC (e.g. acetate, cell residues, humic/fulvic macromolecules) have a variety of sources and functions in peatlands (Blodau 2001). As previously detailed, annual DOC export can be in the same range as annual $\mathrm{CH}_{4}$ emissions (Roulet et al. 2007). The production and supply of this DOC impacts the activity of methanogens. Simple compounds such as acetate, ethanol and glucose have been identified as the dominant substrates used by methanogens for $\mathrm{CH}_{4}$ production, with ethanol being preferentially consumed in the first 12 hours after laboratory incubation of rice paddy sediment (Chawanakul et al. 2009, Kirstine \& Galbally 2012). For fen peat samples, Coles and Yavitt (2002) demonstrated that 
available substrates influence methanogenic activity. After adding acetate, ethanol or glucose, their results showed that net methanogenesis increased immediately following acetate addition, and within 24 hours after addition of ethanol and glucose, which must be degraded by fermentation into smaller compounds for uptake by methanogens (Coles \& Yavitt 2002). As measurements were made immediately following substrate addition, the increase in $\mathrm{CH}_{4}$ production cannot be attributed to population growth response, which requires more time, and thus provides evidence for substrate limitation of methanogenesis. The quantity of organic substrate was also highlighted as a limitation on $\mathrm{CH}_{4}$ production through in vitro assays, where $\mathrm{CH}_{4}$ production was enhanced by the addition of substrates to saturated peat originating from bog hollows (Yavitt \& SeidmanZager 2006).

The quality of the DOC supply can also influence $\mathrm{CH}_{4}$ production rates. The quality of DOC is influenced by major environmental controls including WT position, peat temperature and surface vegetation (Lai 2009). Recent studies found that DOC for peatlands with a raised WT was more labile and less humified in comparison to lowered WT conditions. WT drawdown resulted in increased pore water DOC concentrations with higher aromaticity, possibly resulting from DOC leaching from increased plant production under lowered WT conditions (Moore et al. 1998, Hribljan 2012, Hribljan et al. 2014). A peat warming experiment in a poor fen in Michigan showed that pore water DOC increased in both lability and concentration for warmed plots (Kane et al. 2014). This is expected as the rate of temperature-dependent decomposition processes increase with warming (Kane et al. 2014). Furthermore, the quality of peatland DOC can be influenced by surface vegetation characteristics, as acid-insoluble OM is typical of shrub- 
dominated sites and has been shown to be negatively correlated with $\mathrm{CH}_{4}$ production in peat from Appalachian wetland sites (Yavitt \& Lang 1990). Similarly, in a substrate manipulation experiment with incubated peat samples collected from five different sites at Storåmyren, Sweden, (minerotrophic lawn, ombrotrophic lawn, ombrotrophic wet carpet, mud-bottom, ombrotrophic hummock), Bergman et al. (2000) suggested that easily degradable substrate availability, as well as temperature, influenced $\mathrm{CH}_{4}$ production rates within sites. Chanton et al. (2008) examined peat from a variety of northern peatland sites (Minnesota, Northern Alberta, and Alaska) and their results suggest that DOC from sedge-dominated peatlands is more labile than DOC from peatlands dominated by Sphagnum or other woody plants. DOC was relatively young in comparison to bulk peat for these peatlands regardless of surface vegetation, indicating that fresh and more recent plant $\mathrm{C}$ is important for DOC dynamics (Chanton et al. 2008). As DOC fuels $\mathrm{CH}_{4}$ producing microbes in saturated peat layers, the quantity and quality of DOC substrate supply represent important environmental controls on peatland $\mathrm{CH}_{4}$ emissions.

\subsubsection{Peat temperature and acidity}

Northern peatland $\mathrm{CH}_{4}$ production and emission rates increase with increasing peat temperature. Moore and Dalva (1993) demonstrated this through a laboratory column study of subarctic and temperate peat in which averaged $\mathrm{CH}_{4}$ emissions at $23^{\circ} \mathrm{C}$ were 6.6 times greater than at $10^{\circ} \mathrm{C}$. Temperature relations are commonly expressed using $\mathrm{Q}_{10}$ values, which represent the change in reaction rate per $10^{\circ} \mathrm{C}$ change in temperature. For example, $\mathrm{CH}_{4}$ emissions from peat monoliths (originating from Scottish Ellergower moss hollows) suggested methanogenesis $Q_{10}$ values ranging from 2.1-4.0 
(Thomas et al. 1996). In an incubation analysis of peat slurries from temperate and subarctic peatlands, $\mathrm{CH}_{4}$ production also demonstrated strong temperature dependence with $\mathrm{Q}_{10}$ values ranging from 5.3 to 16 (Dunfield et al. 1993). Both $\mathrm{CH}_{4}$ production and consumption processes were optimized at about $25^{\circ} \mathrm{C}$ in this study. However, consumptive $\mathrm{CH}_{4}$ oxidation processes were not as sensitive to temperature, as indicated by lower $\mathrm{Q}_{10}$ values of 1.4 to 2.1 (Dunfield et al. 1993).

Methane transport mechanisms can also be influenced by temperature. Ebullition $\mathrm{CH}_{4}$ flux in particular can be moderated by temperature, where peat cooling events cause the contraction of ebullition bubbles and dissolution of $\mathrm{CH}_{4}$ which limit ebullition over the short-term (Fechner-Levy \& Hemond 1996). Increases in peat temperature could potentially increase $\mathrm{CH}_{4}$ transport through ebullition as bubble volumes increase and $\mathrm{CH}_{4}$ gas accumulates (Fechner-Levy \& Hemond 1996). Plant $\mathrm{CH}_{4}$ transport can also be enhanced with warmer temperatures as pressurized ventilation in the aerenchyma increases and subsequently allows for greater flow of $\mathrm{CH}_{4}$ to the atmosphere (Große 1996). As such, numerous studies have reported the importance of peat temperature near the average position of the WT as an important control on $\mathrm{CH}_{4}$ emissions (Bubier et al. 1995b, Moore et al. 2011, Lai et al. 2014a, Brown et al. 2014, Turetsky et al. 2014).

Peat acidity is also a control on $\mathrm{CH}_{4}$ processes as the activities of methanogenic and methanotrophic organisms peak under specific optimum conditions. Methanogens have been shown to grow optimally at $\mathrm{pH}$ ranging from 6 to 8 (Garcia et al. 2000). Methanotrophs favour more acidic peat ranging from pH 4.3 to 5.9 (Kamal \& Varma 2008). After incubating peat slurries, Dunfield et al. (1993) found that native peat $\mathrm{pH}$ was about $2 \mathrm{pH}$ units lower than optimum $\mathrm{pH}$ ranges for $\mathrm{CH}_{4}$ production and consumption in 
temperate and subarctic peat (5.5-7.0 and 5.0-6.5 respectively). As Sphagnum-dominated ombrotrophic bogs such as Mer Bleue are rain-fed peatlands, they do not receive significant quantities of mineral bases derived from groundwater. Consequently, the acidic decomposition products remain unneutralized and the surface waters of bogs are characterized by an acidic $\mathrm{pH}$ of about 4 (Shotyk 1988). As the $\mathrm{pH}$ of ombrotrophic bogs lies outside the optimum ranges for $\mathrm{CH}_{4}$ production and consumption, the acidity of these peatlands may limit the activity of both methanogens and methanotrophs.

\subsubsection{Vegetation community structure}

As northern latitude peatlands are expected to experience higher temperatures and longer growing seasons, predictions suggest vascular plants will out-compete bryophytes and lichens (Walker et al. 2006, IPCC 2007, Gallego-Sala \& Prentice 2013). Warming experiments have demonstrated the potential for deciduous shrubs and graminoids to increase in height and cover, while mosses and lichens decrease in cover due to shade intolerance (Walker et al. 2006).

Previous studies have demonstrated that vegetative community composition is a good indicator of $\mathrm{CH}_{4}$ exchange within and among peatlands (Bubier 1995, Bubier et al. 1995a, Dias et al. 2010, Couwenberg et al. 2011, Levy et al. 2012, Gallego-Sala \& Prentice 2013, Ward et al. 2013). The composition of the plant community not only reflects environmental variables such as nutrient availability and long-term WT depths, but also directly impacts $\mathrm{CH}_{4}$ exchange by supplying root exudates, increasing available substrates to methanogens, regulating peat moisture and influencing transport through the $\mathrm{CH}_{4}$ consumption zone (Couwenberg et al. 2011, Bridgham et al. 2013, Ward et al. 
2013). For instance, Ward et al. (2013) found that vegetative community composition, particularly graminoid presence, was more important than a $1{ }^{\circ} \mathrm{C}$ increase in air temperature for regulating $\mathrm{CH}_{4}$ flux within an ombrotrophic blanket bog in northern England. Similarly, a $\mathrm{CH}_{4}$ flux model for data from 21 sites in the United Kingdom showed that the highest explanatory power stemmed from plant composition data (Levy et al. 2012). As previously detailed, plant communities dominated by sedges are associated with enhanced $\mathrm{CH}_{4}$ emission presumably because sedges allow $\mathrm{CH}_{4}$ produced at depth to bypass the consumption zone through aerenchymatous tissues (Couwenberg et al. 2011, Ward et al. 2013). Sedges also provide methanogens with an increased supply of acetate and other organic substrates (Ward et al. 2013). However, Strack et al. (2008) suggest that at sites with dense sedge cover (i.e. drained lawns), $\mathrm{O}_{2}$ transported below the WT may enhance oxidation in the catotelm over the short term (2-5 years) and could reduce net $\mathrm{CH}_{4}$ emissions.

\subsection{Measurement techniques and approaches}

\subsubsection{Autochamber $\mathrm{CH}_{4}$ flux measurements}

Methane gas exchange between the surface and the atmosphere may be measured using a number of techniques including chambers and eddy covariance. The manual static non-steady state chamber method uses the increase in $\mathrm{CH}_{4}$ concentration in the chamber headspace over time to calculate the $\mathrm{CH}_{4}$ flux at the surface (Pihlatie et al. 2013). This method is 'static' in that there is no air flow circulating between the chamber and an analyzer. Instead, discrete air samples are collected over time manually. While chambers are portable and inexpensive, the $\mathrm{CH}_{4}$ flux data from these chambers are limited both 
spatially and temporally (e.g. fewer plots sampled at weekly to monthly intervals) due to practical constraints of manual sample collection (Lai et al. 2014a). In the eddy covariance technique, $\mathrm{CH}_{4}$ fluxes are measured as the covariance of high frequency vertical wind velocity fluctuations and $\mathrm{CH}_{4}$ mixing ratio fluctuations over a period of time such as 30 min with the appropriate air density and water vapour corrections applied (e.g. Brown et al. 2014). Eddy covariance $\mathrm{CH}_{4}$ flux measurements represent the flux from an integrated area of roughly 1 ha and are thus difficult to interpret in relation to dominant vegetation types and common environmental variables that vary spatially (Lai et al. 2014a). These limitations highlight the value of automated chamber measurements, which achieve a higher temporal resolution than manual chamber measurements (e.g. one measured flux for each chamber every half hour) and increase the likelihood of observing elevated but transient $\mathrm{CH}_{4}$ emission phenomena in specific plots representing the plant communities.

\subsubsection{Stable isotope analysis}

In conjunction with autochamber $\mathrm{CH}_{4}$ flux measurements, stable $\mathrm{C}$ isotope analysis has the potential to reveal more detail into peatland $\mathrm{CH}_{4}$ emission processes. Carbon exists as two stable isotopes in natural environments, ${ }^{12} \mathrm{C}$ and ${ }^{13} \mathrm{C}$, with relative abundances of $98.9 \%$ and $1.1 \%$ respectively (Farquhar et al. 1989). Stable isotope fractionation occurs because heavier isotopes (i.e. ${ }^{13} \mathrm{C}$ ) are cycled and transformed differently than lighter isotopes (i.e. ${ }^{12} \mathrm{C}$ ) through biogeochemical processes including photosynthesis, respiration, and physical processes such as diffusion (Dawson \& Siegwolf 2007). These processes alter the ${ }^{13} \mathrm{C} /{ }^{12} \mathrm{C}$ composition of $\mathrm{C}$-containing matter 
and gases in the soil, biosphere and atmosphere, creating isotopic signatures that can be used to trace $\mathrm{C}$ transformation processes (Farquhar et al. 1989, Werner et al. 2012).

Stable $\mathrm{C}$ isotope analysis adopted the use of delta notation to express any sample's abundance of ${ }^{13} \mathrm{C}$ in relation to ${ }^{12} \mathrm{C}$ (Werner et al. 2012). According to Quay et al. (1991), $\delta^{13} \mathrm{C}$ is the ratio of ${ }^{13} \mathrm{C}$ to ${ }^{12} \mathrm{C}$ in parts per thousand, per mil (\%o), relative to a marine carbonate standard, PeeDee Belemnite:

$$
\delta^{13} C=\left(\frac{{ }^{13} C /{ }^{12} C_{S A M}}{{ }^{13} C /{ }^{12} C_{V-P D B}}-1\right) \times 1000
$$

The PeeDee Belemnite international standard was based on a marine fossil found in South Carolina's Pee Dee formation, which had an unusually high ratio of ${ }^{13} \mathrm{C}$ relative to ${ }^{12} \mathrm{C}$ (Werner et al. 2012). PeeDee Belemnite was established as $\delta^{13} \mathrm{C}=0 \%$, thus most natural samples have a negative $\delta^{13} \mathrm{C}$ value because they are more depleted in ${ }^{13} \mathrm{C}$ than the standard. With increasing isotope studies and greater demand for use of the standard, the original PeeDee Belemnite had to be replaced with Vienna PeeDee Belemnite (VPDB) (Werner et al. 2012).

The three main $\mathrm{CH}_{4}$ source categories have distinct isotopic signatures, with microbially produced $\mathrm{CH}_{4}$ having more depleted average values $\left(\delta^{13} \mathrm{C}_{-} \mathrm{CH}_{4}=-60 \%\right.$ ) than fossil fuel $\mathrm{CH}_{4}\left(\delta^{13} \mathrm{C}_{-} \mathrm{CH}_{4}=-40 \%\right.$ ) or biomass burning $\mathrm{CH}_{4}\left(\delta^{13} \mathrm{C}_{-}-\mathrm{CH}_{4}=-25 \%\right.$ ) (Quay et al.1991, Miller 2005). The measured steady state atmospheric $\delta^{13} \mathrm{C}_{-} \mathrm{CH}_{4}$ value of $-47 \%$ is offset by $6 \%$ from the signature of atmospheric $\mathrm{CH}_{4}$ sources $\left(\delta^{13} \mathrm{C}_{-}-\mathrm{CH}_{4}=-53 \%\right.$ ) due to isotopic fractionation associated with global $\mathrm{CH}_{4}$ sinks (i.e. tropospheric $\mathrm{OH}$, soils, and stratosphere) (Whiticar 2000, Miller 2005). Peatland $\mathrm{CH}_{4}$ emissions are dominated by 
microbially produced $\mathrm{CH}_{4}$ with $\delta^{13} \mathrm{C}-\mathrm{CH}_{4}$ values ranging from -85 to $-40 \%$ due to the influence of production, consumption, and transport processes (Hornibrook et al. 2000a). Peatland isotopic signatures also vary depending on the time of year. For example, Avery et al. (1999) found that $\delta^{13} \mathrm{C}_{-} \mathrm{CH}_{4}$ of pore water could shift by up to $11 \%$ annually at a Michigan peatland. This temporal variation was attributed to the shift of dominant $\mathrm{CH}_{4}$ production pathway from $\mathrm{CO}_{2}$ reduction $(\sim-71 \%)$ in the winter to acetate fermentation ($44 \%$ ) in the spring. The $\mathrm{CH}_{4}$ production pathways can be distinguished by their $\delta^{13} \mathrm{C}$ $\mathrm{CH}_{4}$ values as acetate fermentation yields a relatively ${ }^{13} \mathrm{C}$-enriched signature (-65 to -50 $\%$ ) compared to the more depleted $\mathrm{CO}_{2}$ reduction signature (-110 to $-60 \%$ ) (Whiticar et al. 1986). This is due to stronger methanogenic discrimination against ${ }^{13} \mathrm{C}$ during $\mathrm{CO}_{2}$ reduction relative to acetate fermentation (Dorodnikov et al. 2013). Parent OM (i.e. $\mathrm{C}_{3}$ vs. $\mathrm{C}_{4}$ vegetation) will also influence $\delta^{13} \mathrm{C}_{-} \mathrm{CH}_{4}$ values (Chanton et al. 2005). An increased understanding of these $\mathrm{CH}_{4}$ production pathways reveals information about decomposition patterns (i.e. fresh vs. old C) and the fate of C pools (i.e. pools with rapid turnover time vs. pools with longer turnover time) (Dorodnikov et al. 2013).

Methane consumption processes driven by methanotrophs cause shifts in ${ }^{13} \mathrm{C}$ isotopic signatures as well. Coleman et al. (1981) found that residual $\mathrm{CH}_{4}$ from bacterial $\mathrm{CH}_{4}$ oxidation became enriched in ${ }^{13} \mathrm{C}$. Thus, the microbes preferentially consume lighter ${ }^{12} \mathrm{C}_{-} \mathrm{CH}_{4}$, leaving residual $\mathrm{CH}_{4}$ enriched with the heavier ${ }^{13} \mathrm{C}$ isotope in the upper peat layer (Dorodnikov et al. 2013). This $\mathrm{C}$ isotope fractionation factor was found to range from 5 to $30 \%$ in various culture experiments (Whiticar 1999).

Transport processes also affect $\mathrm{CH}_{4}$ isotopic signatures. The $\mathrm{CH}_{4}$ diffusion distance through the aerated zone influences the $\delta^{13} \mathrm{C}-\mathrm{CH}_{4}$ value since methanotrophs 
fractionate $\mathrm{C}$ as discussed above while at the same time, diffusion and plant-mediated transport processes preferentially remove lighter ${ }^{12} \mathrm{C}-\mathrm{CH}_{4}$. Methane fractionation may then be dependent on WT position (i.e. thickness of aerobic zone), transport mechanism and day of year/time of day (Dorodnikov et al. 2013). As increased sedge cover would allow for increased plant-mediated $\mathrm{CH}_{4}$ transport, the vegetation community structure may influence the dominant $\mathrm{CH}_{4}$ transport pathway and $\delta^{13} \mathrm{C}-\mathrm{CH}_{4}$ values accordingly.

\subsubsection{Keeling Plot Approach}

The $\delta^{13} \mathrm{C}-\mathrm{CH}_{4}$ signatures of $\mathrm{CH}_{4}$ sources can be determined using the Keeling Plot approach. First proposed by Charles Keeling $(1958,1960)$, the "Keeling Plot" two endmember mixing model analyzes the relationship between the concentration and isotopic abundance of trace gases, such as $\mathrm{CH}_{4}$, in the atmosphere (Miller \& Tans 2003, Pataki et al. 2003). This approach relies on the conservation of mass, where the sampled ecosystem atmospheric $\mathrm{CH}_{4}$ concentration $\left(\mathrm{c}_{\mathrm{a}}\right)$ is a combination of the background $\mathrm{CH}_{4}$ concentration ( $\mathrm{c}_{\mathrm{b}}$ ) and source $\mathrm{CH}_{4}$ concentration ( $\mathrm{c}_{\mathrm{s}}$ ) (Pataki et al. 2003):

$$
c_{a}=c_{b}+c_{s}
$$

This method assumes that the only two gas components mixing are the source and background $\mathrm{CH}_{4}$ and that their isotopic ratio stays constant over the observation period (Pataki et al. 2003). As such, each $\mathrm{CH}_{4}$ component's $\mathrm{C}$ isotope ratio $\left(\delta^{13} \mathrm{C}\right)$ follows the equation:

$$
\delta^{13} C_{a} c_{a}=\delta^{13} C_{b} c_{b}+\delta^{13} C_{s} c_{s}
$$

By substituting equation (5) into equation (6), 


$$
\begin{aligned}
& \delta^{13} C_{a} c_{a}=\delta^{13} C_{b} c_{b}+\delta^{13} C_{s}\left(c_{a}-c_{b}\right) \\
& \delta^{13} C_{a} c_{a}=\delta^{13} C_{b} c_{b}+\delta^{13} C_{s} c_{a}-\delta^{13} C_{s} c_{b} \\
& \delta^{13} C_{a} c_{a}=c_{b}\left(\delta^{13} C_{b}-\delta^{13} C_{s}\right)+\delta^{13} C_{s} c_{a} \\
& \delta^{13} C_{a}=\left(c_{b} / c_{a}\right)\left(\delta^{13} C_{b}-\delta^{13} C_{s}\right)+\delta^{13} C_{s}
\end{aligned}
$$

where $\delta^{13} \mathrm{C}_{\mathrm{a}}$ is the isotopic composition of the sampled $\mathrm{CH}_{4}, \delta^{13} \mathrm{C}_{\mathrm{b}}$ is the isotopic composition of the background $\mathrm{CH}_{4}$, and $\delta^{13} \mathrm{C}_{\mathrm{s}}$ is the isotopic composition of the $\mathrm{CH}_{4}$ source component. As Equation 10 is in $y=(m / x)+b$ linear form, the source $\delta^{13} \mathrm{C}_{\mathrm{s}}$ value is the y-intercept $b$ in this linear regression approach (Miller \& Tans 2003). Figure 2-2 demonstrates a sample Keeling Plot, where the inverse $\mathrm{CH}_{4}$ concentration is plotted against $\delta^{13} \mathrm{C}-\mathrm{CH}_{4}$ to obtain a y-intercept that represents the isotopic signature of the $\mathrm{CH}_{4}$ source (Miller \& Tans 2003, Pataki et al. 2003). In this example, the relatively depleted source $\delta^{13} \mathrm{C}-\mathrm{CH}_{4}$ value of $-71.7 \%$ indicates the dominance of the $\mathrm{CO}_{2}$ reduction pathway for $\mathrm{CH}_{4}$ production. 


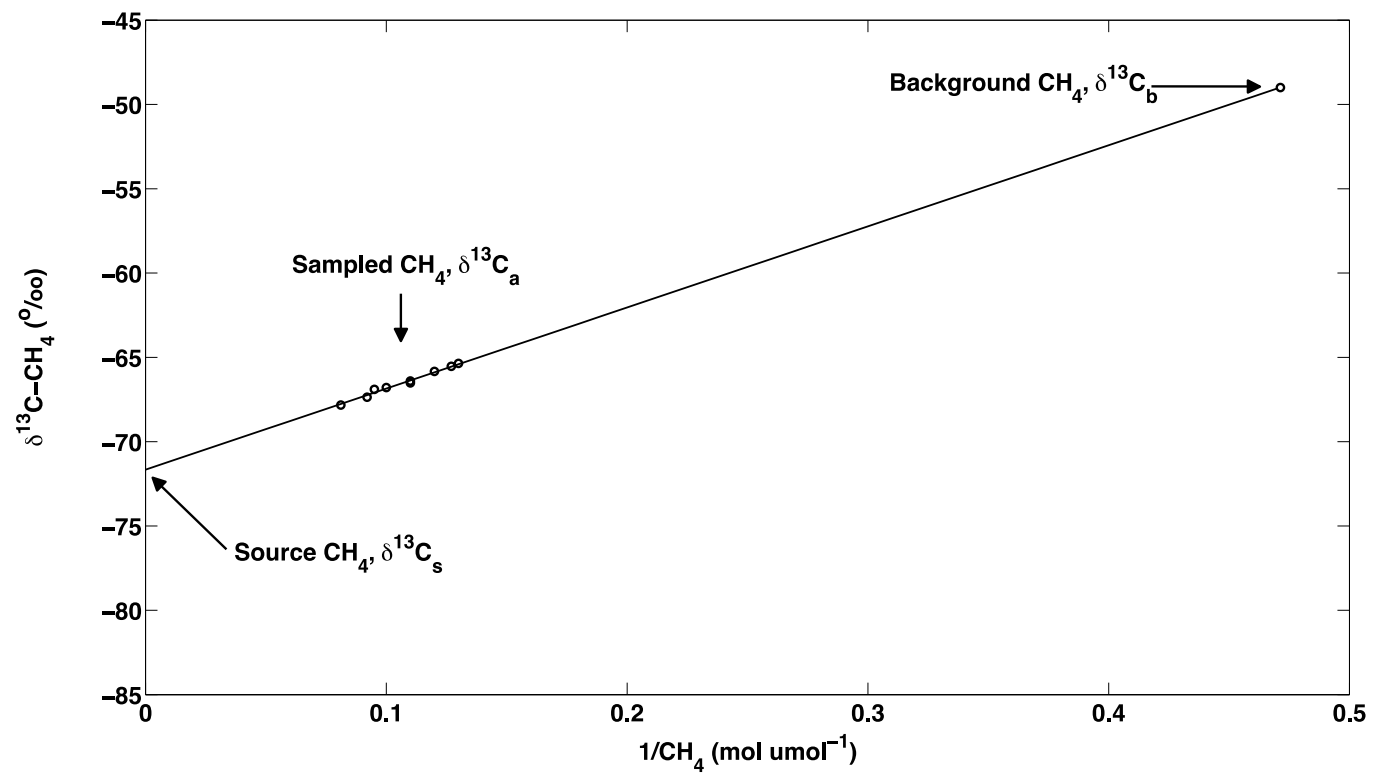

Figure 2-2: The Keeling Plot method as described by Equation 10. Inverse $\mathrm{CH}_{4}$ concentrations ( $\mathrm{mol} \mu \mathrm{mol}^{-1}$ ) are plotted vs. isotope ${ }^{13} \mathrm{C} /{ }^{12} \mathrm{C}$ ratios (\%). The isotopic signatures of sampled $\mathrm{CH}_{4}\left(\delta^{13} \mathrm{C}_{\mathrm{a}}\right)$ and background $\mathrm{CH}_{4}\left(\delta^{13} \mathrm{C}_{\mathrm{b}}\right)$ are shown with open circles. The y-intercept (-71.7\%o) is interpreted as the isotopic signature of the $\mathrm{CH}_{4}$ source, $\delta^{13} \mathrm{C}_{\mathrm{s}}$. 


\subsubsection{Redox potential measurements}

As $\mathrm{CH}_{4}$ production and consumption processes are microbially mediated, they require specific reduction-oxidation conditions for maximum activity levels. For example, strongly reducing conditions $(<-200 \mathrm{mV})$ are favourable for the activity of methanogens, which are obligate anaerobes (Table 2-1; Zhi-Guang 1985, Mansfeldt 2003, Vorenhout et al. 2004). Methanotrophs, however, require $\mathrm{O}_{2}$ as an electron acceptor and thus peak in activity under oxidizing conditions $(>400 \mathrm{mV})$. Accordingly, the redox status of the peat substrate is an important parameter for investigating the spatial and temporal variability of $\mathrm{CH}_{4}$ production potential. Measurements of the voltage difference between the peat substrate and a standard reference electrode represent the peat redox potential (Eh, $\mathrm{mV}$ ) (Vorenhout et al. 2004). Redox potential indicates the ability of the peat substrate to gain or lose electrons and can range from +800 to -600 $\mathrm{mV}$. Recent technological advances provide the opportunity for automated and continuous redox potential measurements from multiple locations in peatlands (Vorenhout et al. 2004, Vorenhout et al. 2011). With a field deployable multichannel datalogger and probe system, Eh profiles and temperature can be continuously monitored (e.g. 10 min frequency) and help inform the spatial and temporal variability of potential $\mathrm{CH}_{4}$ production as a function of variation in temperature, microbial activity, WT position, and other environmental factors. 


\subsubsection{Pore water collection and analysis}

To elucidate peat processes and associated turnover patterns at depth, vertical concentration profiles of chemical species in peatland pore water are commonly used (Blodau 2001, Blodau \& Moore 2002). These pore water profiles allow for the quantification of processes along specific depth intervals, where the mass balance between these depths enhances process understanding of peat layers (Blodau 2001). Peatland pore water has historically been collected in situ by using equilibrium diffusion chambers ("peepers") or suction samplers. As introduced by Hesslein (1976), the peeper technique relies on diffusive equilibration principles for in situ pore water collection without sample degassing or oxidation (Steinmann \& Shotyk 1996, Gao et al. 2012). The peeper itself is typically constructed of Plexiglas or some sort of acrylic body that is equipped with a continuous series of dialysis chambers at certain depth intervals and dialysis membranes that separate the chambers from the surrounding peat. The chambers, which are filled with deionized water before installation, equilibrate with the surrounding pore water through diffusion of dissolved constituents (Steinmann \& Shotyk 1996, Gao et al. 2012). While the peeper technique produces higher resolution concentration profiles, it requires long equilibration times of 27-270 hours at minimum (Gao et al. 2012). These peepers can also disturb the peat plot into which they are installed, and they come at a high cost. This hinders the technique's utility for investigating temporal variations in pore water composition at multiple plots simultaneously and at the same plot multiple times.

The suction method of pore water extraction was thus developed to enable repeated sample collection from the same research plot. Pore water sampling via suction requires the installation of tubular samplers into the site peat, followed by the application 
of weakly negative pressure to the tube for sample collection (Gao et al. 2012). Blodau and Moore (2002) found that retrieving peat pore water through suction could result in a mix of pore water from various depths and pore sizes. When compared to pore water collected from a peeper, the pore water collected via suction had higher dissolved inorganic carbon (DIC) concentrations with larger variability in values and more gradual concentration gradients (Blodau \& Moore 2002). Thus, peat pore water extracted through suction techniques could produce concentration patterns that are partially confounded by macroporosity effects including preferential flow patterns. However, these sampling devices do not cause disruption to the peat layers to the same extent as larger peepers. In addition, pore water from suction samplers can be collected without device removal and does not require long equilibration times thus allowing for higher frequency measurements and more constrained temporal investigations. For deeper pore water, simple stand-pipe piezometers can be used, as they are less expensive and easier to install than peepers (Waddington et al. 2009, Gao et al. 2012). In a study investigating whether the presence of piezometers impacts below-surface pore water $\mathrm{CH}_{4}$ concentrations at two peatlands, Waddington et al. (2009) concluded that pore water obtained from open piezometers had significantly lower $\mathrm{CH}_{4}$ concentrations than pore water from sealed samplers. The open piezometers created preferential flow paths in the peat, allowing $\mathrm{CH}_{4}$ to vent to the atmosphere (Waddington et al. 2009). Although piezometers can alter peatland gas dynamics, the disturbance is minimized with sealed piezometers. Therefore, to enhance understanding of both spatial and temporal variability of pore water constituents and their role in peatland $\mathrm{CH}_{4}$ dynamics, the suction sampling technique and 
use of sealed piezometers are viable alternatives to the classic equilibrium diffusion chambers.

The present study focuses in particular on the differences in $\mathrm{CH}_{4}$ cycling dynamics among plant community types during a wet summer at the Mer Bleue ombrotrophic bog in Ottawa, Ontario, Canada. It aims to provide a more detailed examination of indicators of $\mathrm{CH}_{4}$ production, storage and transport processes for three dominant vegetative communities at Mer Bleue through the analysis of $\mathrm{CH}_{4}$ fluxes in conjunction with measurements of emitted stable isotope signatures, pore water depth profiles and redox potential. Previous studies at this site have examined the spatial and temporal variability of $\mathrm{CH}_{4}$ emissions (Lai et al.2014a, Moore et al. 2011), ecosystemscale $\mathrm{CH}_{4}$ emissions (Brown et al. 2014), and belowground $\mathrm{CH}_{4}$ dynamics (Blodau 2001, Blodau \& Moore 2003a, Blodau \& Moore 2003b, Blodau et al. 2007), yet none have simultaneously investigated the high frequency temporal variability of $\mathrm{CH}_{4}$ emissions with pore water characteristics in conjunction with isotopic techniques across the main vegetative communities. The current study hopes to provide further understanding of the production, storage and transport processes that control $\mathrm{CH}_{4}$ emissions at Mer Bleue. 


\subsection{METHODS}

\subsection{Site description}

The Mer Bleue peatland complex is located $10 \mathrm{~km}$ east of Ottawa, Ontario $\left(45.41^{\circ} \mathrm{N}\right.$, $75.48^{\circ} \mathrm{W}$ ) covering a $28 \mathrm{~km}^{2}$ area (Figure 3-1) (Roulet et al 2007, Moore et al. 2011, Lai et al. 2012). The region is characterized by a cool continental climate with a mean annual air temperature of $6.4 \pm 0.8^{\circ} \mathrm{C}$ and mean annual precipitation of $943 \mathrm{~mm}, 47 \%$ of which falls during the growing season between May and September (1981-2010, Environment Canada 2014). Westerly winds blow most frequently, with an average annual velocity of $13 \mathrm{~km} \mathrm{~h}^{-1}$. Each year, the first fall frost arrives $\sim$ October 7 at Mer Bleue and the last spring frost occurs $\sim$ April 30, with $\sim 210$ days where the air temperature is above freezing (Environment Canada 2014). While winter snow cover conditions vary widely between years, peak snow packs tend to range between 60 and $80 \mathrm{~cm}$ with snow cover present from December through March (Lafleur et al. 2003).

The progression of events leading to the formation of Mer Bleue bog is described in detail by Roulet et al. (2007). While the oldest lake sediments of the Mer Bleue peatland basin are $\sim 9000$ years old, the conditions for the peatland's formation began prior to 13,200 years ago when regional ice retreat enabled the invasion of Glacial Lake Iroquois. By 13,100 years ago, the Champlain Sea invaded this area and laid down 40-50 m of silty clay marine sediments. Freshwaters were dominant again in this basin around 10,600 years ago. Between 12,000 and 9500 years ago, outbursts from the Ottawa River eroded the postglacial channel system (in which Mer Bleue now lies) into the former floor of the Champlain Sea basin. The Mer Bleue peatland's formation spanned the last 8400 years, 
with initial development as a fen, which replaced the existing lake. This was followed by bog phase initiation between 7100 and 6800 years ago (Roulet et al. 2007, Moore et al. 2011).

The northwestern arm of the Mer Bleue peatland complex is dominated by a domeshaped ombrotrophic bog (Figure 3-1), which has hosted a long-term C cycling research program for 17 years. This area has an undulating hummock-lawn-hollow microtopography with a $0.25 \mathrm{~m}$ mean difference in elevation between hummock and hollow (Lafleur et al. 2003). The peat depth varies by $\sim 5 \mathrm{~m}$ from the center $(5-6 \mathrm{~m})$ to the margins $(<0.3 \mathrm{~m})$ where a band of beaver ponds encircles the bog (Roulet et al. 2007). The bog surface is covered by Sphagnum moss (primarily Sphagnum capillifolium, Sphagnum magellanicum and Sphagnum angustifolium) with some Polytrichum strictum present. At an average height of 0.2-0.3 m, the dominant evergreen and deciduous shrubs include: Chamaedaphne calyculata, Ledum groenlandicum (=Rhododendron groenlandicum), Kalmia angustifolia and Vaccinium myrtilloides. Sedges (Eriophorum vaginatum) and select small trees on hummocks (Larix laricina and Betula populifolia) add sparse cover to the bog surface (Moore et al. 2011). Mer Bleue is considered to be a relatively dry bog, as indicated by the 1998-2014 mean growing season WT depth of 42 $\mathrm{cm}$ below hummock top at the tower site. Over this 16 -year period, the mean growing season WT position ranged from 33 to $50 \mathrm{~cm}$ below peat surface, with observed daily WT minimum and maximum of 78 and $23 \mathrm{~cm}$ below the peat surface respectively. 


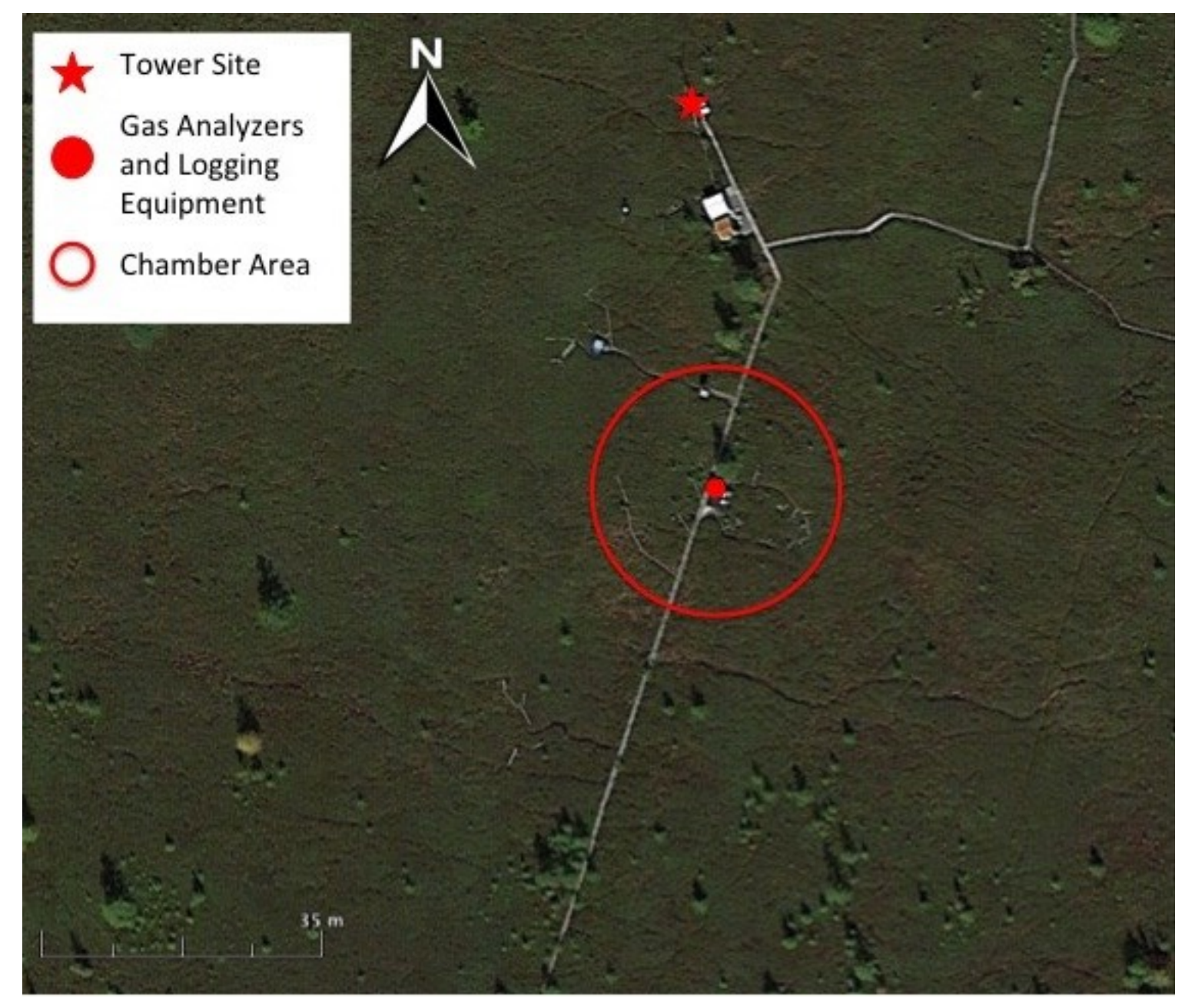

Figure 3-1: Location of the tower site, gas analyzers and logging equipment, and chamber area at the Mer Bleue research site. The star, representing the tower site, is located at $45^{\circ} 24^{\prime} 33^{\prime \prime} \mathrm{N}, 75^{\circ} 31^{\prime} 07^{\prime \prime} \mathrm{W}$. Map data: Google, Digital Globe (Imagery Date: 9/24/2013). 


\subsubsection{Sampling Area}

The research sampling area was composed of 6 automated chamber and 3 manual chamber plots located approximately $50 \mathrm{~m}$ south of the eddy covariance tower (Figure 3-1). The autochambers were chosen to be representative of the dominant vascular plant communities including Chamaedaphne- and Ledum-dominated communities (plots C-A 1, 2, and 3 and plots L-A 1, 2 and 3, respectively), while manual chambers were chosen to represent the Eriophorum-dominated community (plots E-M 1, 2, and 3). While the number of sampling chambers was limited by the existing infrastructure and physical arrangement of dominant plant communities, the nine selected chambers also captured this peatland's range in microtopography and WT. The autochamber and manual chamber plots were accessed via wooden boardwalks to minimize peat damage and vegetation disturbance. Each chamber was located $<15 \mathrm{~m}$ from the gas analyzers and logging equipment (Figure 3-1). The characteristics of each chamber plot, including dominance of vascular and nonvascular species and leaf area index (LAI), are presented in Table 3-1. Leaf area index was measured weekly at each chamber as $\mathrm{m}^{2}$ leaf area per $\mathrm{m}^{2}$ ground area $\left(\mathrm{m}^{2} \mathrm{~m}^{-2}\right)$ using two methods. First, biomass LAI was measured using a Plant Canopy Analyzer (LAI-2000, LI-COR Inc., Lincoln, NE). This instrument calculates the ratio of foliage area to ground area based on radiation measurements made above ( 2 measurements) and below (3 measurements) the standing plant canopy but does not include the LAI associated with creeping species or moss. It also cannot distinguish between living and dead foliage and simply gives a measure of canopy light interception. Green LAI was determined using the point intercept method. The point intercept frame $(60 \times 60 \mathrm{~cm})$ had a fishing line grid of $5 \times 5 \mathrm{~cm}$ squares for a total of 121 grid points. 
The frame was leveled and centered above each sampling collar and a metal rod $(8 \mathrm{~mm}$ diameter) was dropped at alternating grid points such that it was perpendicular to and touching the moss carpet (Adkinson 2009). The number of times the rod came in contact with a living vascular plant organ (leaf, stem, flower, shoot) for each species was recorded over 35 and 9 grid points for automated and static chamber collars, respectively (Larmola et al. 2013). The \% cover and species composition of the vascular and nonvascular canopy was also determined (Table $3-1$ ). All chambers plots had $100 \%$ or near $100 \%$ moss cover for the duration of the growing season. 
Table 3-1: Vegetation characteristics at the 9 chamber plots including dominance (\%) of vascular and nonvascular plant species, growing season maximum biomass leaf area index (LAI, $\mathrm{m}^{2} \mathrm{~m}^{-2}$ ), total and Eriophorum vaginatum (EV) green LAI, and maximum percent of $E V$ cover.

\begin{tabular}{|c|c|c|c|c|c|c|}
\hline Chamber & $\begin{array}{l}\text { Vascular plant species } \\
\quad(\% \text { dominance })^{a}\end{array}$ & $\begin{array}{l}\text { Nonvascular } \\
\text { plant species } \\
(\% \text { dominance })^{a}\end{array}$ & $\begin{array}{c}\text { Max. } \\
\text { biomass } \\
\text { LAII } \\
\left(m^{2} m^{-2}\right)^{b}\end{array}$ & $\begin{array}{l}\text { Max. total } \\
\text { green LAI } \\
\left(m^{2} m^{-2}\right)^{b}\end{array}$ & $\begin{array}{c}\text { Max. } \boldsymbol{E V} \\
\operatorname{green} \boldsymbol{L A I} \\
\left(m^{2} m^{-2}\right)^{b}\end{array}$ & $\begin{array}{l}\text { Max. } \\
\% \text { EV } \\
\text { cover }\end{array}$ \\
\hline \multicolumn{7}{|c|}{ Chamaedaphne } \\
\hline$C-A 1$ & $\begin{array}{c}\text { CC } 53 \%, \text { EV } 27 \%, \text { LG } 10 \%, \text { VO } 5 \%, \\
\text { VM } 3 \% \text {, MT } 2 \%\end{array}$ & SP $63 \%$, P $37 \%$ & 2.83 & 6.03 & 2.03 & 34 \\
\hline$C-A 2$ & $\begin{array}{c}\text { CC } 84 \%, \text { LG } 8 \%, \text { VO 5\%, MT 2\%, VM } \\
1 \%\end{array}$ & P $60 \%$, SP $40 \%$ & 3.61 & 6.83 & 0 & 0 \\
\hline$C-A 3$ & EV $50 \%$, CC 42\%, LG 6\%, VM 2\% & P $57 \%$, SP $11 \%$ & 7.24 & 10.54 & 6.34 & 60 \\
\hline \multicolumn{7}{|l|}{ Ledum } \\
\hline$L-A 1$ & $\begin{array}{c}\text { LG } 40 \%, \text { EV } 40 \%, \text { MT } 10 \%, \text { CC } 9 \%, \\
\text { VO } 1 \%\end{array}$ & SP $96 \%$, P $4 \%$ & 6.56 & 5.32 & 2.66 & 53 \\
\hline$L-A 2$ & $\begin{array}{c}\mathrm{EV} 74 \%, \mathrm{LG} 18 \%, \mathrm{KA} 3 \% \text {, VO 3\% MT } \\
2 \%\end{array}$ & SP $87 \%$, P $8 \%$ & 5.19 & 10.74 & 8.71 & 82 \\
\hline$L-A 3$ & EV $68 \%$, LG $22 \%$, MT 7\%, VO 3\% & SP $67 \%$, P $31 \%$ & 4.22 & 8.09 & 5.83 & 74 \\
\hline \multicolumn{7}{|c|}{ Eriophorum } \\
\hline$E-M 1$ & EV 97\%, LG $1 \%$, CC $1 \%$, MT $1 \%$ & SP $70 \%$, P $6 \%$ & 5.33 & 21 & 20.44 & 99 \\
\hline$E-M 2$ & EV $83 \%$, CC 9\%, VO 5\%, MT 3\% & SP $64 \%$, P $22 \%$ & 4.18 & 12.11 & 11.11 & 93 \\
\hline$E-M 3$ & $\begin{array}{c}\text { EV } 89 \%, \text { VO } 6 \%, \text { KA } 2 \%, \text { CC } 2 \%, \text { LG } \\
1 \%\end{array}$ & SP $94 \%$, P $0 \%$ & 4.14 & 12.78 & 12.11 & 96 \\
\hline
\end{tabular}

${ }^{a}$ CC: Chamaedaphne calyculata, EV: Eriophorum vaginatum, KA: Kalmia angustifolia, LG: Ledum (rhododendron) groenlandicum, MT: Maianthemum trifolium, VM: Vaccinium myrtilloides, VO: Vaccinium oxycoccos, AP: Andromeda polifolia, P: Polytrichum moss, SP: Sphagnum moss.

${ }^{b}$ From DOY 133 to DOY 239. 


\subsection{Data collection}

\subsubsection{Autochamber $\mathrm{CH}_{4}$ flux measurements}

The existing autochamber system (Figure 3-2) was used to collect chamber flux measurements $24 \mathrm{~h}_{\text {day }}{ }^{-1}$ between May 1 and October 1, 2014. Each autochamber (see Appendix A Section 7.0) was constructed using a PVC collar (height $=0.385 \mathrm{~m}$ ) inserted into the peat and attached to a clear Plexiglas ${ }^{\circledR}$ dome by an aluminum frame (see Lai et al. 2012 for full description). The collars enclosed a surface area of $0.21 \mathrm{~m}^{2}$ (internal diameter $=0.52 \mathrm{~m}$ ) with collars inserted to a depth of 0.16 to $0.31 \mathrm{~m}$ (Figure $3-4)$, which minimized air leakage through the peat. The autochamber domes were $0.205 \mathrm{~m}$ high and were sealed when closed by a partially-deflated bicycle tube and foam gasket. The chamber headspace air was mixed by a small brushless fan fixed to the inside of the dome. Pressure equilibration between external and internal environments was achieved during autochamber flux measurements through a $0.50 \mathrm{~m}$ long vent tube that was coiled, open at both ends and emerged from the dome top.

The autochamber system was controlled by a datalogger (CR23X, Campbell Scientific) and was programmed to close the chamber domes sequentially every half hour for 2.5 minutes during the day (09:00-21:00 EST) to minimize plant stress, and 15 minutes at night (21:00-09:00 EST) to minimize bias introduced by atmospheric turbulence (Lai et al. 2012). This produced a measured flux value for all chambers each half hour during the day and every 4 hours at night. An oil-free air compressor and pneumatic cylinder system powered the opening and closing of chambers. Sampling tubes drew the gases from the appropriate chamber to a sampling manifold where $\mathrm{CH}_{4}$ 
concentrations were measured using a fast $\mathrm{CH}_{4}$ analyzer using off-axis integrated cavity output spectroscopy (model DLT-100, Los Gatos Inc., Mountain View, CA), and $\mathrm{CO}_{2}$ concentrations were measured by a closed-path infrared gas analyzer (LI-6262, LI-COR Inc.) in a temperature controlled housing. Sampled once per second and averaged every 5 seconds, gas analyzer data were automatically sent to a computer in an enclosed hut at the nearby tower site (Figure 3-1). The gas analyzers and autochambers were maintained regularly, particularly at the beginning of the season (e.g. replaced tubing, patched leaks, repaired fans). The system's equipment (gas analyzers, data logger, air compressor and manifold and pump system) was located under a shelter at the junction of the primary and secondary boardwalks (Figure 3-5).

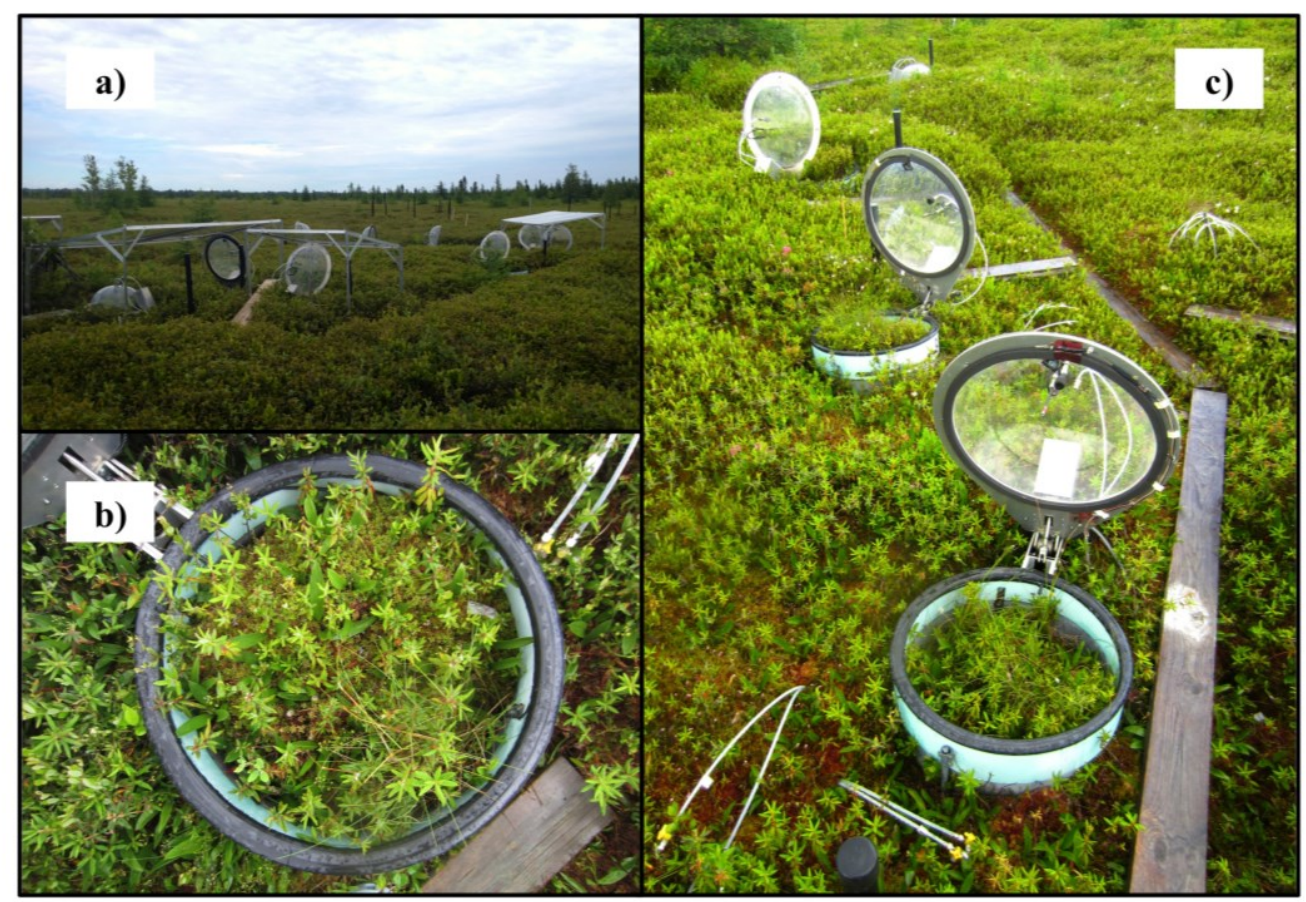

Figure 3-2: Photos of a) the autochamber system at Mer Bleue used to measure $\mathrm{CH}_{4}$ fluxes at b) the plant community scale with c) a Plexiglas ${ }^{\circledR}$ dome fitted to a PVC collar. 
Flux data were processed in Matlab 8.1.0.604 (The Math Works, Inc., 2013). Only nighttime data were used as the autochambers closed for 15 minute periods, which reduced the flux underestimations caused when winds flush the near surface peat and there is an associated decrease in headspace turbulence during deployment (Lai et al. 2012). When deployment periods are too short ( $<13$ minutes), these turbulence conditions influence headspace $\mathrm{CH}_{4}$ concentrations after the chamber closes. As a result, we used only the last 250 seconds of data to calculate nighttime $\mathrm{CH}_{4}$ fluxes. $\mathrm{CH}_{4}$ fluxes $\left(F_{C H 4}\right.$, nmol m $\left.\mathrm{m}^{-2} \mathrm{~s}^{-1}\right)$ were calculated as:

$$
F_{C H 4}=\frac{\rho V}{R^{*} T_{\text {air }} A} \frac{d C}{d t}
$$

where $\rho$ is air pressure $(\mathrm{Pa}), V$ is chamber volume $\left(\mathrm{m}^{3}\right), R^{*}$ is the ideal gas constant $\left(8.314 \mathrm{~J} \mathrm{~K}^{-1} \mathrm{~mol}^{-1}\right), T_{\text {air }}$ is mean air temperature $\left({ }^{\circ} \mathrm{K}\right), A$ is chamber surface area $\left(\mathrm{m}^{2}\right)$, and $d C / d t$ is the rate of change in $\mathrm{CH}_{4}$ mixing ratio in the chamber over the measurement period (nmol mol-1 dry air s${ }^{-1}$ ). The mixing ratio of $\mathrm{CH}_{4}$ takes into consideration the effects of water vapour dilution and was calculated using the headspace mole fraction of $\mathrm{CH}_{4}$ and the water vapour mole fraction measured by the LI-6262 gas analyzer. A negative $\mathrm{CH}_{4}$ flux indicates uptake by the peatland while a positive flux indicates $\mathrm{CH}_{4}$ loss to the atmosphere. 


\subsubsection{Static chamber $\mathrm{CH}_{4}$ flux measurements}

As there were no existing autochamber plots representative of the Eriophorumdominated community, 3 Eriophorum plants for manual $\mathrm{CH}_{4}$ flux measurement were selected in close proximity to the autochamber system (Figure 3-3).

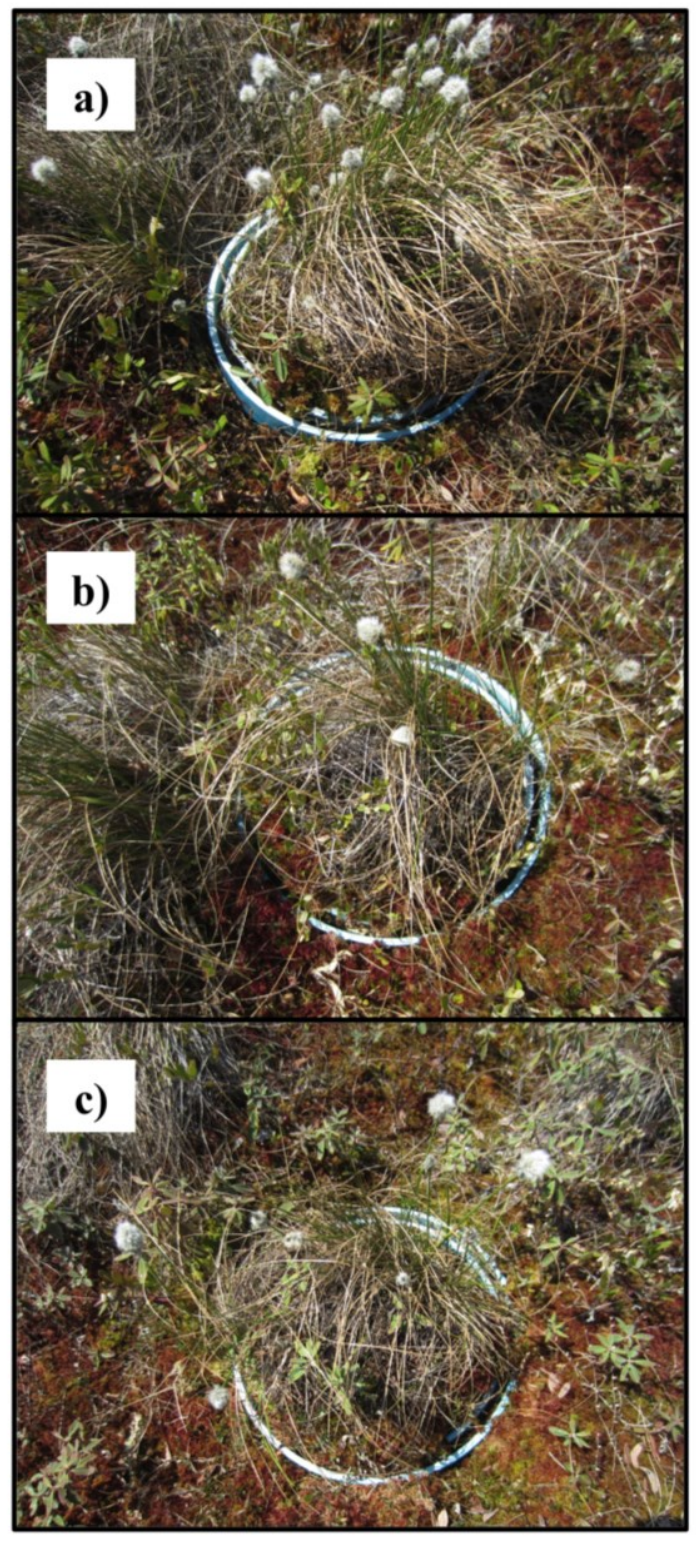

Figure 3-3: Photos of manual chamber collars inserted into the peat at a) E-M 1, b) E-M 2 and c) E-M 3 Eriophorum plants. 
Grooved collars of $0.24 \mathrm{~m}$ internal diameter (surface area $=0.05 \mathrm{~m}^{2}$ ) were inserted $\sim 10$ $\mathrm{cm}$ into the peat to be compatible with existing $18 \mathrm{~L}$ opaque chambers at the site. All manual chambers were covered with aluminum foil tape to minimize temperature increase during measurement (Bubier et al. 1995a). Flux measurements were made at least twice weekly (2-3 rounds per sampling day) between 07:00 and 15:00 EST. A seal was created between collar and chamber during the measurement period by filling the collar grooves with water. The air in these static chambers was sampled at 5 min intervals for a total of $20 \mathrm{~min}$ starting at time 0 . First, $60 \mathrm{cc}$ of air was pumped between a sealed syringe and the chamber via tubing 3 times to mix the headspace air. Next $24 \mathrm{cc}$ of air was extracted and injected via syringe and needle to an evacuated $12 \mathrm{cc}$ vial with a small amount of magnesium perchlorate as a desiccant. Vials were analyzed for $\mathrm{CH}_{4}$ mixing ratio on a Varian CP-3800 gas chromatograph at Carleton University, with methods described in detail by Wilson \& Humphreys (2010). The gas chromatograph used flameionization detection and methanizer technology at $300^{\circ} \mathrm{C}$ and $350^{\circ} \mathrm{C}$, respectively, with a He carrier gas at an injection rate of $30 \mathrm{ml} \mathrm{min}^{-1}$. Quality control was maintained during gas sampling using three replicates of five standards (439.2-15212.6 ppm CO $2,1.08-19.4$ ppm $\mathrm{CH}_{4}$ ) and He blanks. The chamber was removed for at least 2 minutes between successive rounds of flux measurements.

The slope of the regression between $\mathrm{CH}_{4}$ concentration and time during the 20minute sampling period was used to calculate $\mathrm{CH}_{4}$ fluxes (Roulet et al. 2007) following Equation 11. Samples were rejected when $\mathrm{CO}_{2}$ and $\mathrm{CH}_{4}$ concentrations remained close to ambient concentrations for the duration of the sampling period when a substantial flux was expected given the measurements from that chamber during a particular time period, 
indicating contamination of the sample with ambient air through a possible chamber or vial leak. Samples were also rejected when there was a large initial spike in $\mathrm{CO}_{2}$ and $\mathrm{CH}_{4}$ concentrations, as this suggested that the placement of the chamber on the collar disturbed the peat and caused a rapid degassing of trace gases to the chamber headspace. Approximately $17 \%$ of samples were rejected.

Although there were some inherent differences among the chamber sampling methods (static vs. circulating flow, collar area, chamber headspace, slope determinations), we were confident that the two methods were comparable as the magnitude and temporal variability of fluxes from the Eriophorum plots were very similar to those presented by Lai et al. (2014a) when the autochambers had been located on Eriophorum plants near the static chamber plots used in this study.

\subsubsection{Pore water collection}

Weekly pore water collection occurred between 07:00 and 15:00 EST starting on June 4 and ending on September 12, 2014. In order to minimize vegetation and subsurface peat disturbance within sampling collars, pore water was collected at least 20 $\mathrm{cm}$ from the collar edge in an area with similar moss and vegetation cover. The order of pore water collection for each sampling plot was randomized week-to-week. A portable pore water sipper (Figure 3-5a) was used to collect pore water directly below the WT on each sampling day. The sipper was inserted into the peat at the required depth and a 60 $\mathrm{ml}$ syringe was attached to the top of the sipper with a 3-way stopcock. The syringe was used to pull up and flush out $30 \mathrm{ml}$ of pore water. After flushing, $30 \mathrm{ml}$ of pore water was collected and the stopcock was closed to the atmosphere. 
Pore water at 50, 65 and $80 \mathrm{~cm}$ below the peat surface was collected using permanent pore water samplers (Figure 3-4, Figure 3-5b). Pore water "seepers" were constructed from a section of PVC piping (length $=15 \mathrm{~cm}$, internal diameter $=2.54 \mathrm{~cm}$ ) with rows of holes at $1 \mathrm{~cm}$ intervals drilled $10 \mathrm{~cm}$ from the sealed end of the seeper and covered in fine mesh. Rubber stoppers were inserted at both ends of the seeper and two small holes were drilled through the top stopper so that two Bev-A-Line tubes could be installed for sample extraction and nitrogen pressure equalization. A 3-way stopcock was added at the end of each tube to enable the use of a syringe above the peat surface. Pore water seepers were installed at 50,65 and $80 \mathrm{~cm}$ on June 4, 2014 at each plot. Pore water was collected from seepers using a similar method to the sipper procedure. A $60 \mathrm{ml}$ syringe was attached to the stopcock of the sample extraction tube emerging from the peat. A Tedlar bag (volume=1L) filled with nitrogen was attached to the second tube's stopcock for pressure equilibration. After opening the stopcocks to enable nitrogen flow to depth and pore water flow to surface, a syringe was used to pull up and flush out $30 \mathrm{ml}$ of pore water. The $30 \mathrm{ml}$ pore water sample was then collected and both stopcocks were closed. 


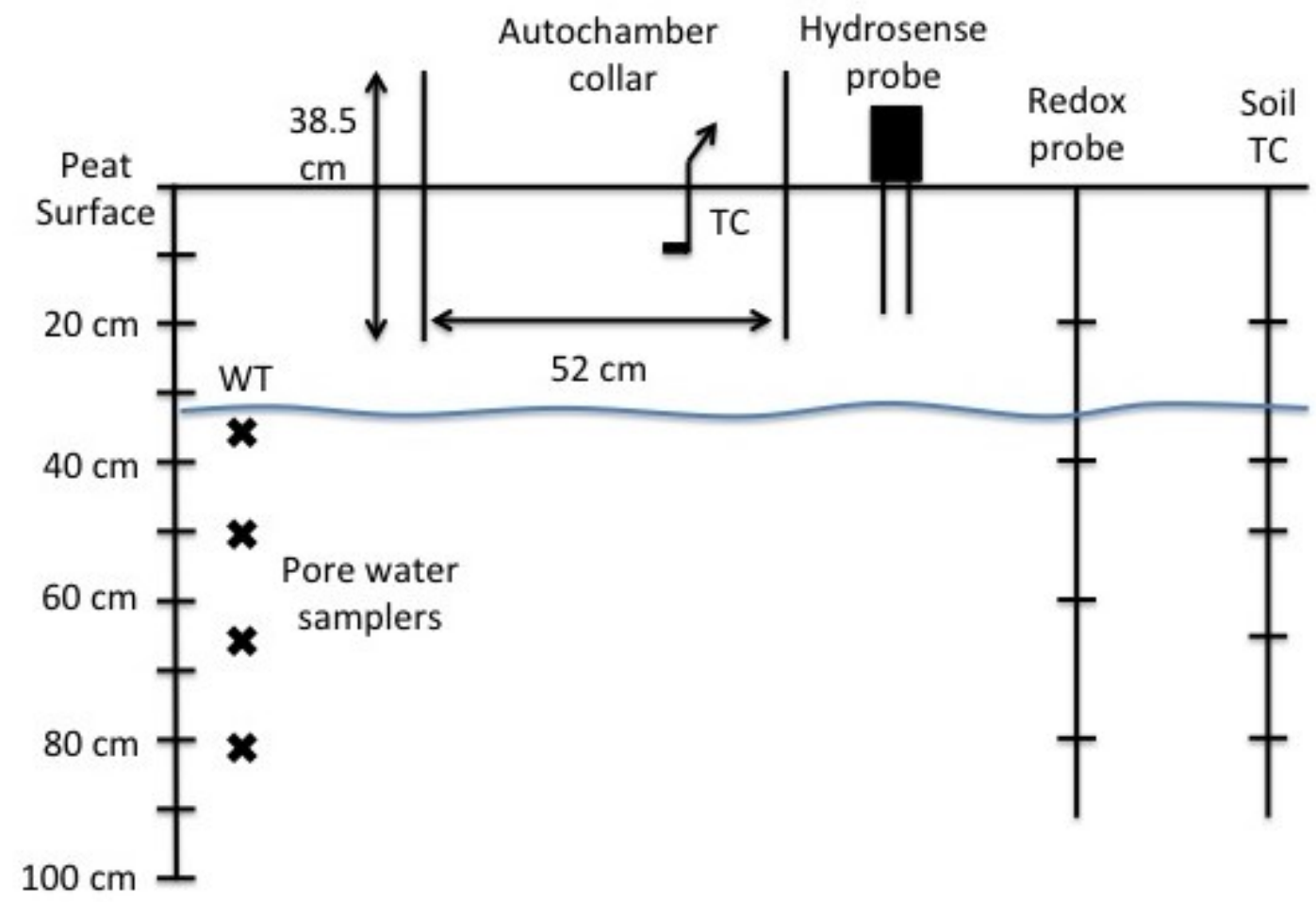

Figure 3-4: Example setup of instrumentation at an autochamber collar showing sampling depths for pore water samplers, Hydrosense probe, redox probe and soil thermocouples (TC) inside and outside the chamber collar. Note that only a single soil thermocouple profile was installed and was located near the flux tower $\sim 50 \mathrm{~m}$ from the autochambers. All other sensor placements and depths are to scale.

A secondary pore water sampler was designed and installed on August 6, 2014 at 50, 65 and $80 \mathrm{~cm}$ for each plot. This fat sipper design consisted of a piezometer for each sampling depth (internal diameter $=1.91 \mathrm{~cm}$ ) with holes drilled at the appropriate depth, a cap sealing the bottom and a cap and septa at the top (Figure 3-5c). Before the first sampling, piezometers were flushed with nitrogen via tubing and a 22-gauge (0.7 $\mathrm{mm}$ x $25 \mathrm{~mm}$ ) needle piercing the septa in the top cap (a second needle was inserted into the septa to allow for pressure equilibration). Samples were obtained by removing the top septa and cap, inserting a sipper and collecting pore water as per the sipper and syringe 
method described above. After pore water extraction, the piezometers were sealed and flushed with nitrogen to limit $\mathrm{O}_{2}$ entry to the subsurface.

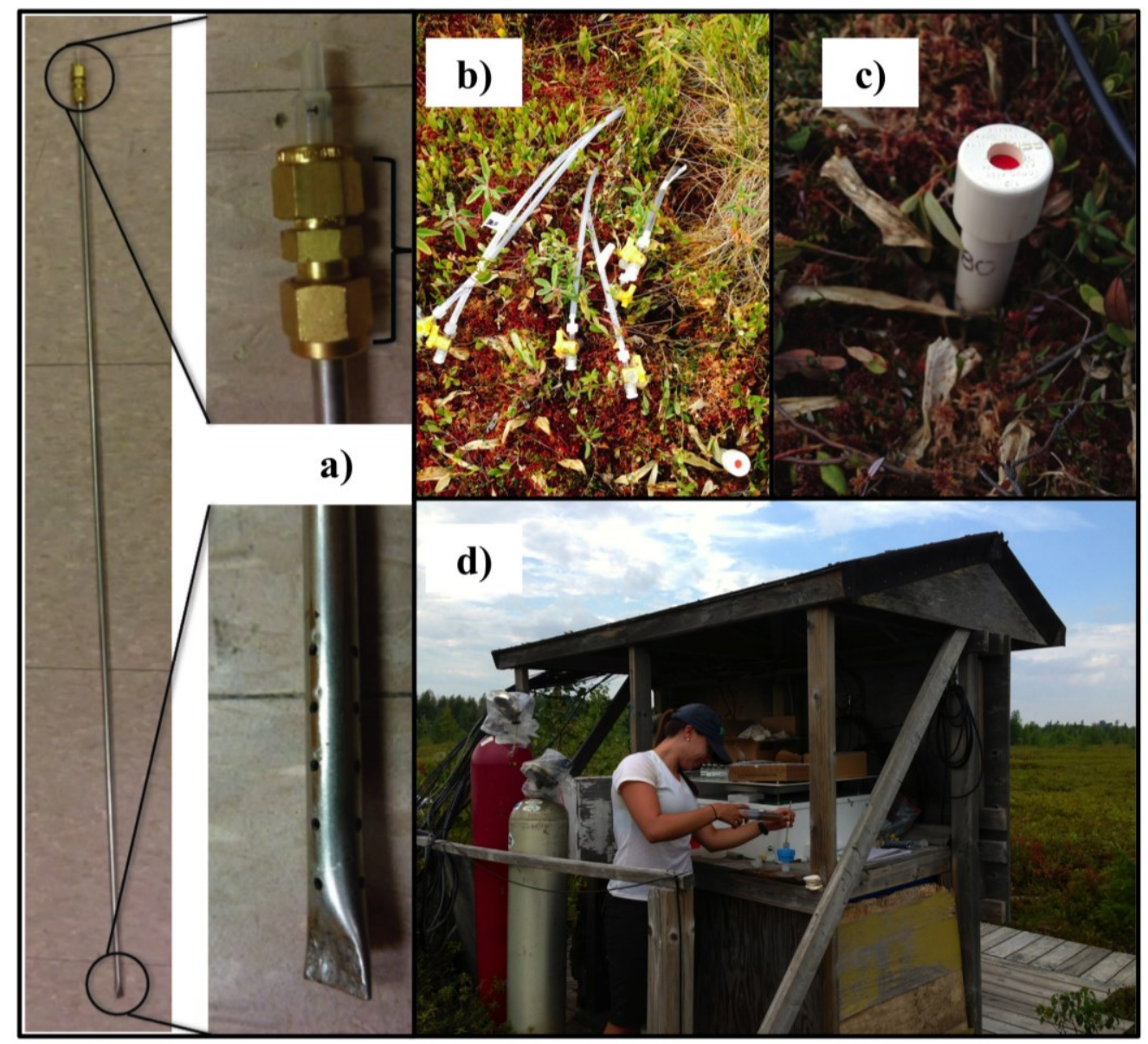

Figure 3-5: Photos of pore water sampling instrumentation where a) a pore water sipper was used to collect pore water from depths $<50 \mathrm{~cm}$ below peat surface and permanent $\mathrm{b}$ ) pore water seepers and c) piezometers were used to collect pore water at 50,65 and 80 $\mathrm{cm}$. After samples were collected, d) pore water filtration and equilibration for isotope analysis was carried out in the field at a small equipment hut.

Once a $30 \mathrm{ml}$ pore water sample was obtained in a $60 \mathrm{ml}$ syringe using the above methods, the remaining $30 \mathrm{ml}$ of the syringe was filled with ambient air. The stopcock was then closed to the atmosphere and the syringe was shaken for 2 minutes to equilibrate liquid and gas $\mathrm{CH}_{4}$ concentrations. The syringe headspace was pushed through a 22-gauge needle to displace saltwater in a $30 \mathrm{ml}$ vial (sealed and crimped) until 
$15 \mathrm{ml}$ of headspace remained in the syringe. The remaining $15 \mathrm{ml}$ of headspace sample air was used to overpressurize the saltwater solution. $2.5 \mathrm{ml}$ of gas in the headspace was analyzed for $\mathrm{CH}_{4}$ on the Varian $\mathrm{CP}-3800$ as described above. The water remaining in the syringe was then filtered through a $0.40 \mu \mathrm{m}$ glass fiber filter (diameter $=47 \mathrm{~mm}$ ) and stored in a $20 \mathrm{ml}$ scintillation vial in the fridge for DOC analysis. Pore water $\mathrm{CH}_{4}$ concentrations ( $\left.\mu \mathrm{mol} \mathrm{L}{ }^{-1}\right)$ were calculated according to the equations found in Appendix B Section 7.0.

Pore water samples were analyzed on a Shimadzu TOC/TN-V $V_{\text {CSN }}$ analyzer at McGill University for DOC $\left(\mathrm{mg} \mathrm{L}^{-1}\right)$ and total dissolved nitrogen, TDN $\left(\mathrm{mg} \mathrm{L}^{-1}\right)$ using the combustion catalytic oxidation method at $680^{\circ} \mathrm{C}$. The carbon to nitrogen ratio $(\mathrm{C} / \mathrm{N})$ was calculated as the ratio between DOC and TDN. UV absorbance $\left(\mathrm{m}^{-1}\right)$ was determined at 250, 254 and $365 \mathrm{~nm}$ on an Agilent Cary $60 \mathrm{UV}$-Vis spectrophotometer with a fiber optic dip probe in dual beam mode at a scan rate of $600 \mathrm{~nm} / \mathrm{min}$. The aromaticity of DOC was approximated by calculating specific ultraviolet absorbance at $254 \mathrm{~nm}, \mathrm{SUVA}_{254}$ (L $\left.\mathrm{m}^{-1} \mathrm{mg}^{-1} \mathrm{DOC}\right)$, as:

$$
S U V A_{254}=\frac{U V \text { Absorbance at } 254 \mathrm{~nm}\left(\mathrm{~m}^{-1}\right)}{D O C\left(m g ~^{-1}\right)}
$$

where the UV absorbance at $254 \mathrm{~nm}\left(\mathrm{~m}^{-1}\right)$ is divided by the DOC concentration $\left(\mathrm{mg} \mathrm{L}^{-1}\right)$. 


\subsubsection{Storage Change}

Each pore water $\mathrm{CH}_{4}$ measurement was representative of a peat layer based on sampling depth $(20 \mathrm{~cm}$, below WT, $50 \mathrm{~cm}, 65 \mathrm{~cm}, 80 \mathrm{~cm})$. For example, the pore air sample taken at $20 \mathrm{~cm}$ represented the aerated zone from the peat surface to the average WT position at each individual chamber. The average WT from DOY 155-255 was determined for each chamber and used to calculate the unique thickness of peat layers for each sampling depth at each chamber. Methane concentration values were weighted for each specific peat layer thickness.

These depth-weighted $\mathrm{CH}_{4}$ concentration values were used for storage change calculations at specific depths (i.e. $50 \mathrm{~cm}$ sampling depth had associated peat layer thickness of $15 \mathrm{~cm}$ ), or after summing over a total depth of $1 \mathrm{~m}$. Units were converted

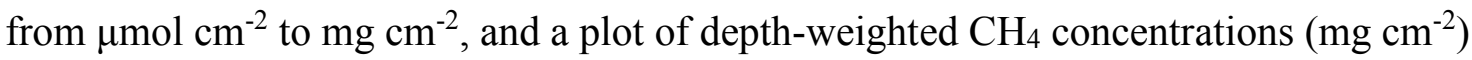
over time (DOY) was constructed for each chamber. Linear regressions were then applied to obtain chamber-specific slope values, where slope represented the change in $\mathrm{CH}_{4}$ storage over time for that chamber $\left(\mathrm{mg} \mathrm{cm}^{-2} \mathrm{~d}^{-1}\right)$. These values were converted to units of $\mathrm{mg} \mathrm{m} \mathrm{m}^{-2} \mathrm{~h}^{-1}$ to obtain final storage change values $\left(\mathrm{S}_{\mathrm{CH} 4}, \mathrm{mg} \mathrm{m}^{-2} \mathrm{~h}^{-1}\right)$. The average $\mathrm{CH}_{4}$ flux $\left(\mathrm{F}_{\mathrm{CH} 4}, \mathrm{mg} \mathrm{m}^{-2} \mathrm{~h}^{-1}\right)$ was then calculated for each chamber over the pore water sampling period using manual sampling day data. 


\subsubsection{Headspace sample collection}

Weekly headspace sample collection occurred on pore water sampling days between July 31 and September 12, 2014. At the end of autochamber and static chamber measurements, $30 \mathrm{ml}$ headspace samples were obtained using the septum-stopcock extraction method with a 22 -gauge needle and syringe. These $30 \mathrm{ml}$ gas samples were injected into evacuated, sealed and crimped $30 \mathrm{ml}$ vials.

Headspace gas samples were analyzed at Arizona State University on a Picarro G2201-i CRDS (Cavity Ring-down Spectroscopy) Analyzer in combined mode for isotopic $\mathrm{C}$ in $\mathrm{CO}_{2}$ and $\mathrm{CH}_{4}$. This instrument had a simultaneous mode precision of $<0.16 \%$ or for $\delta^{13} \mathrm{C}-\mathrm{CO}_{2}$ and $<1.15 \%$ for $\delta^{13} \mathrm{C}-\mathrm{CH}_{4}$, and maximum peak-to-peak drift of $<0.6 \%$ for $\delta^{13} \mathrm{C}-\mathrm{CO}_{2}$ and $<1.5 \%$ for $\delta^{13} \mathrm{C}-\mathrm{CH}_{4}$ (Picarro, Inc. 2015). The sample flow rate was $<50 \mathrm{sccm}$ (typical $\sim 25 \mathrm{sccm}$ ) at $101.3 \mathrm{kPa}$. The isotopic composition and concentration of sample and background $\mathrm{CH}_{4}$ were used to calculate $\delta^{13} \mathrm{C}-\mathrm{CH}_{4}$ source signatures at each chamber through the Keeling Plot approach (Equation 10).

\subsubsection{Redox potential measurements}

This study used a HYPNOS 3 datalogger for redox measurements. The HYPNOS logger measured the difference in potential between the soil matrix and an $\mathrm{Ag} / \mathrm{AgCl}$ reference probe (QM710X from Q-I-S) with $3 \mathrm{M} \mathrm{KCl}$ filling solution. Nine fiberglass probes with platinum sensor tips and temperature sensors (DS18B20, $\pm 5^{\circ} \mathrm{C}$ accuracy from 10 to $85^{\circ} \mathrm{C}$ ) at 20, 40, 60 and $80 \mathrm{~cm}$ (Figure 3-4) were installed adjacent to each chamber on July 18,2014 . The reference probe was installed close to the junction of the main and secondary boardwalks, near the equipment hut (Figure 3-1). The data were 
stored on an SD card (Vorenhout et al. 2011). Readings were recorded every 10 minutes and data were downloaded from the SD card every $\sim 2$ weeks.

Standardized redox potential values $(\mathrm{Eh}, \mathrm{mV})$ were calculated according to:

$$
E_{h}=E_{m}+E_{r e f}
$$

where $E_{h}$ is the standardized redox potential, $E_{m}$ is the measured redox potential, and $E_{r e f}$ is the potential of the reference probe (Vorenhout et al. 2011). As the $\mathrm{Ag} / \mathrm{AgCl}$ reference probe had a $3 \mathrm{M} \mathrm{KCl}$ filling solution, the linear relation between $E_{\text {ref }}$ and temperature (Langmuir 1971) was used to determine temperature-specific $E_{r e f}$ values for the calculation of $E_{h}$ values. These standardized redox potentials were then adjusted for $\mathrm{pH}$ according to:

$$
E_{\text {-corrected }}=E_{h}+59(p H-7)
$$

where the $\mathrm{pH}$ was assumed to be stable at 4 .

\subsubsection{Environmental variables}

Ancillary field measurements included environmental variables presented in Table 3-2. These variables were measured at varying frequency, as indicated in the table, and employed both manual and automated methods. They served to characterize the microclimate and vegetation for each sampling chamber and to quantify differences between vegetative communities.

Wells were established at each sampling plot for the manual measurement of WT position. Depth to WT was measured manually at each plot using a "bubbler" each day 
that manual flux measurements were obtained. WT was also measured at 30 min intervals at each plot throughout the season using automatic capacitive water level loggers installed in wells adjacent to each chamber. Rainfall was measured at 2 rain gauges (NE and $\mathrm{S}$ of main tower site hut) every day that fieldwork was conducted. An existing tipping bucket rain gauge near the eddy covariance tower also measured rainfall at the site, and was calibrated for under-catching using a relationship developed with manual measurements.

Peat temperature was measured continuously at $10 \mathrm{~cm}$ depth using chromelconstantan thermocouples installed in each collar as of May 29, 2014. An existing thermocouple profile at the tower site measured peat temperature at 20, 40, 50, 65 and 80 $\mathrm{cm}$ below the peat surface.

A datalogger (CR7X, Campbell Scientific) and existing instrumentation at the eddy covariance tower site recorded additional climate variables including air temperature, atmospheric pressure, and photosynthetic photon flux density. Lafleur et al. (2003) provide a description of instruments; measurements were recorded every $5 \mathrm{~s}$ and averaged over $30 \mathrm{~min}$.

Air temperature $\left({ }^{\circ} \mathrm{C}\right)$ and rainfall $(\mathrm{mm})$ data collected at Mer Bleue were compared to 30-yr Ottawa climate normals (1981-2010, Environment Canada 2014) measured at the Ottawa International Airport, located approximately $20 \mathrm{~km}$ southwest of the research site. Each month's daily average temperature and standard deviation were analyzed along with total monthly rainfall from May through September. 
Table 3-2: Frequency and method of manual and automated measurements for environmental variables.

\begin{tabular}{|c|c|c|}
\hline Variable & Measurement frequency & Measurement Method \\
\hline WT depth & $\begin{array}{l}2-3 \text { times per week } \\
30 \mathrm{~min}\end{array}$ & $\begin{array}{l}1 \text { well per chamber } \\
\text { Odyssey capacitive water } \\
\text { level logger }\end{array}$ \\
\hline Rainfall & $\begin{array}{l}3-4 \text { times per week } \\
\text { Variable }\end{array}$ & $\begin{array}{l}2 \text { rain gauges } \\
\text { Tipping bucket rain gauge* }\end{array}$ \\
\hline $\begin{array}{l}\text { Peat temperature }(10, \\
20,40,50,65,80 \mathrm{~cm})\end{array}$ & 5s (averaged every $30 \mathrm{~min}$ ) & $\begin{array}{l}\text { Chromel-constantan } \\
\text { thermocouples }\end{array}$ \\
\hline $\begin{array}{l}\text { Air temperature }(0.5 \\
\mathrm{m} \text { height })\end{array}$ & 5s (averaged every $30 \mathrm{~min}$ ) & $\begin{array}{l}\text { Chromel-constantan } \\
\text { thermocouples* }\end{array}$ \\
\hline Atmospheric pressure & 5s (averaged every $30 \mathrm{~min}$ ) & Barometer* \\
\hline $\begin{array}{l}\text { Photosynthetic photon } \\
\text { flux density }\end{array}$ & 5s (averaged every $30 \mathrm{~min}$ ) & Quantum sensor* \\
\hline Biomass LAI & 1 time per week & $\begin{array}{l}\text { LAI-2000 Plant canopy } \\
\text { analyzer }^{\S}\end{array}$ \\
\hline Green LAI & 1 time per week & Point intercept method $\$$ \\
\hline Moss moisture & 2 times per week & Peat tabs $\S$ \\
\hline Moss live sampling & 1 time per week & $\begin{array}{l}\text { Manual collection outside } \\
\text { chamber }^{\S}\end{array}$ \\
\hline $\begin{array}{l}\text { Moss volumetric } \\
\text { water content }\end{array}$ & 2 times per week & $\begin{array}{l}\text { HydroSense soil water } \\
\text { sensor }\end{array}$ \\
\hline
\end{tabular}

Note: LAI=leaf area index.

$\S_{\text {manual measurement }}$

*existing instrumentation at eddy covariance tower site. 


\subsubsection{Statistical analyses}

All statistical analyses were completed using JMP 12.0.1 (SAS Institute Inc.). For seasonal analyses, the data were separated into late spring (LSp, DOY 132-154), early summer (ES, DOY 155-189), mid-summer (MS, DOY 190-221), and late summer (LS, DOY 222-255) measurement periods. Fluxes were available for the late spring period, while pore water data collection started with the early summer period. Redox potential measurements were only active during the late summer period. All data were tested prior to analyses for assumptions of normality and equal variances. Data that did not meet the assumption of normality were transformed. While this did not fully correct the distribution in all cases, the restricted maximum likelihood (REML) method used in mixed model analysis is robust to deviations from normality (Fung \& Xu 2010). Statistical analyses were tested at the significance level of 0.05 , unless otherwise stated.

A simple linear regression analysis was applied to examine the relationship between mean seasonal depth to WT and $\log \mathrm{CH}_{4}$ flux. Averages were determined based on manual static chamber sampling day data to ensure completeness of flux data at Eriophorum plots. The relationship between mean $50 \mathrm{~cm} \mathrm{CH}_{4}$ storage change and mean $\mathrm{CH}_{4}$ flux was examined using a Pearson's correlation analysis and nonlinear regression for manual sampling days during the pore water collection period. The relationships among indicators of $\mathrm{CH}_{4}$ production, storage and transport were examined when all variables were available between DOY 212-255. Analyses of calculated averages of these variables at the $50 \mathrm{~cm}$ depth included a principal components analysis (PCA), and multiple correlation analysis using Pearson correlations. 
Repeated measures analyses using mixed models were applied to investigate $\mathrm{CH}_{4}$ fluxes throughout the growing season, pore water $\mathrm{CH}_{4}$ concentrations during the pore water sampling period (DOY 155-255), and the $\delta^{13} \mathrm{C}_{-} \mathrm{CH}_{4}$ isotopic signatures for headspace sampling days. The model was fit using restricted maximum likelihood (REML) method in the standard least squares personality to view the variation in intercepts and slopes. The REML method is the commonly accepted method for fitting mixed models, as it provides accurate results regardless of whether the data is balanced or not (JMP 7 Statistics and Graphics Guide 2007). The "chamber" variable was designated as a random effect and nested within vegetative community since the chamber plots were randomly selected from the vegetation populations. The fixed effects were analyzed to a factorial degree of 2 in order to examine interaction effects (JMP 7 Statistics and Graphics Guide 2007). 


\subsection{RESULTS}

\subsection{Environmental conditions}

The environmental conditions for the 2014 season at Mer Bleue were analyzed in reference to the 1981-2010 climate normals (Environment Canada 2014) (Figure 4-1). The daily average air temperatures were comparable with Ottawa climate normals for the early summer 2014 period, while the mid- to late-summer periods were slightly cooler than the long-term average. Mer Bleue experienced a wet summer compared to the last 30 years, with particularly heavy rainfall events in June contributing to a total rainfall of $569.0 \mathrm{~mm}$ from May through September in comparison to the climate normal of 440.4 $\mathrm{mm}$ for the same period (Figure 4-1). The WT recorded near the tower (where the long term record has been maintained since 1998) reflected these wet conditions and was high relative to the long-term average (Figure 4-2). 


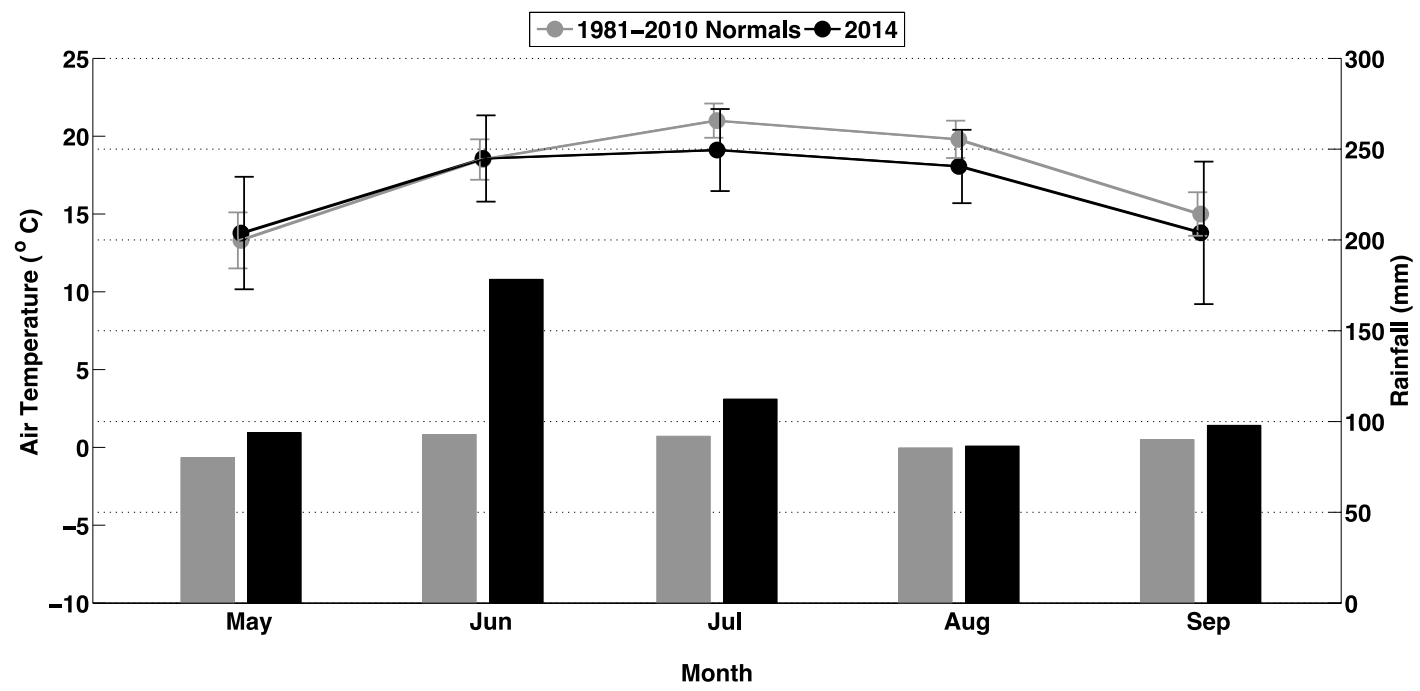

Figure 4-1: Mean ( $\pm 1 \mathrm{SD})$ daily average air temperature (lines) and total monthly rainfall (bars) from May through September 2014 at Mer Bleue peatland in reference to 19812010 climate normals measured at the Ottawa Macdonald-Cartier International Airport (Environment Canada 2014).

The 2014 WT at a given location varied by only $10 \mathrm{~cm}$ from the mean and was thus restricted to a narrow fluctuation range compared to previous years. During 2014, the WT never reached mid-summer depths typical at Mer Bleue. Differences in WT among plant communities were a result of microtopography: Chamaedaphne plants were located on hummock tops while Ledum and Eriophorum were in hollows or depressions between hummocks (Figure 4-2). As a result, the Chamaedaphne community's WT was on average $10 \mathrm{~cm}$ lower than Ledum and Eriophorum communities. Note that the Chamaedaphne community and the tower site had very similar WT depth patterns because of their similar microtopographic position, while Ledum and Eriophorum communities both had WT closer to the surface due to their relatively low position. The 
Eriophorum community had the shortest WT measurement period due to the timing of instrument installation and removal.

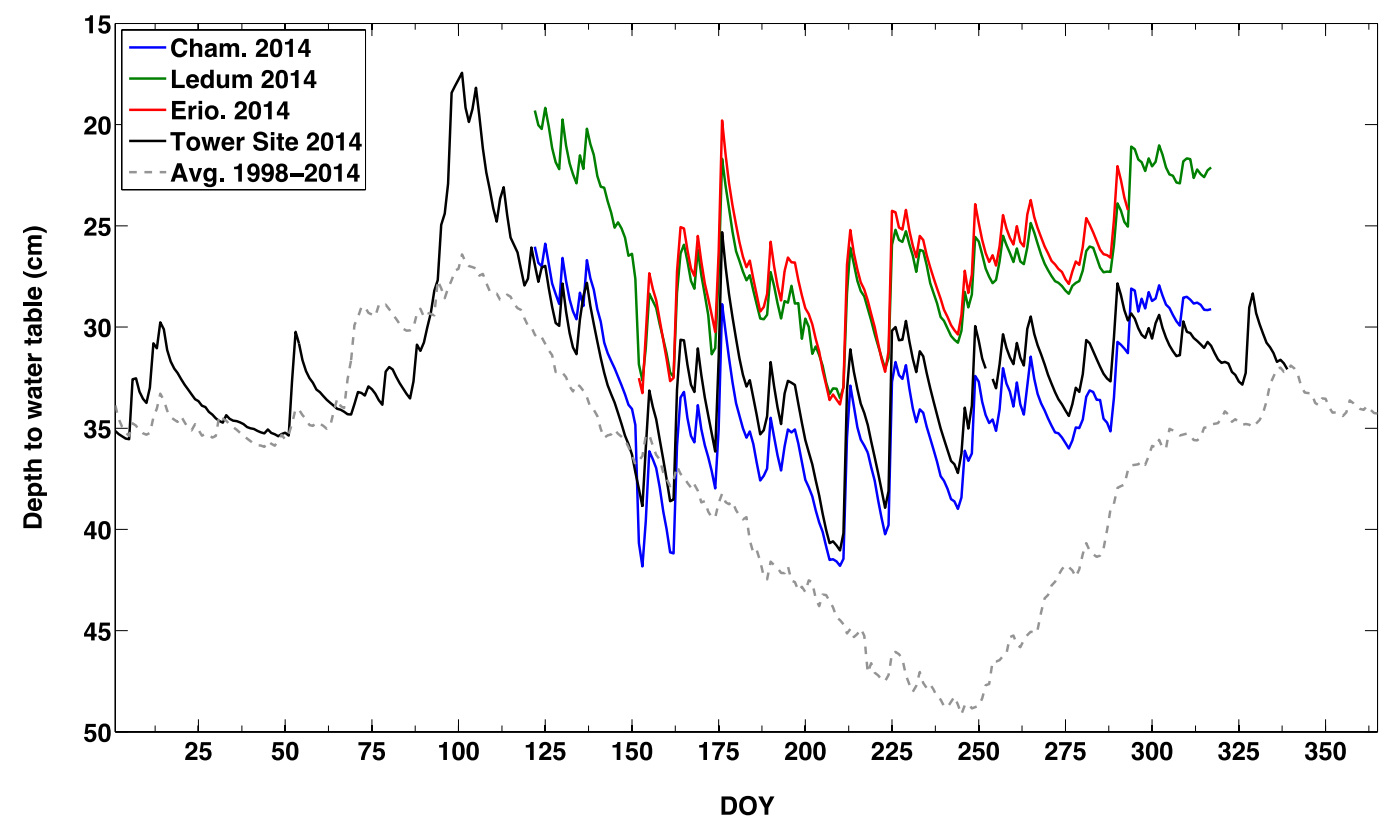

Figure 4-2: Mean daily depth to water table from peat surface $(\mathrm{cm})$ measured at Chamaedaphne, Ledum and Eriophorum-dominated communities and tower site at Mer Bleue, 2014. The long-term mean water table position recorded at the tower site between 1998 and 2014 is shown for comparison. 
The $10 \mathrm{~cm}$ peat temperatures followed daily mean air temperature patterns with slightly dampened day-to-day variations at this depth (Figure 4-3). With increased depth from the peat surface, temperatures were cooler with fewer extreme values as the dampening of day-to-day variations in peat temperature increased with depth (Figure 4-4). At $20 \mathrm{~cm}$ and below, peat temperature consistently increased over the 2014 measurement period to DOY 255.
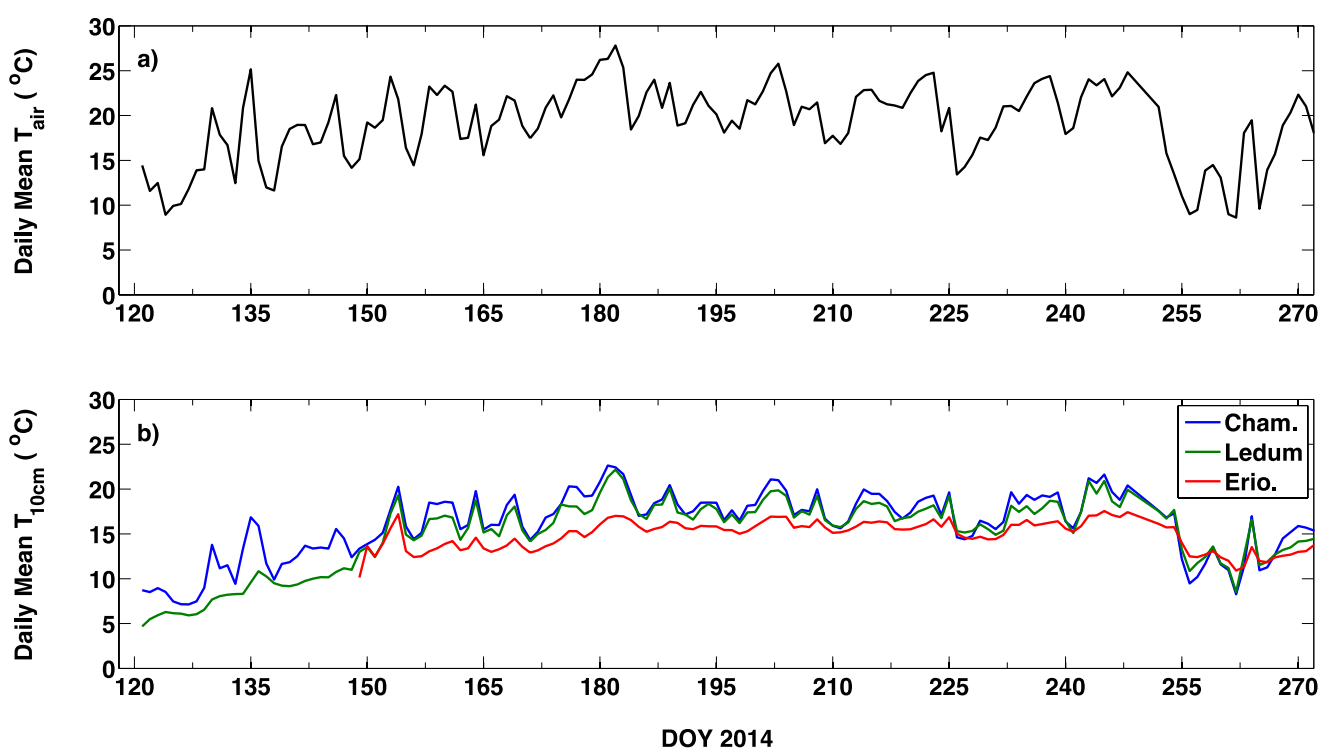

Figure 4-3: Daily mean a) air temperature $\left(\mathrm{T}_{\text {air }},{ }^{\circ} \mathrm{C}\right)$ and $\left.\mathrm{b}\right) 10 \mathrm{~cm}$ peat temperature $\left(\mathrm{T}_{10 \mathrm{~cm}}\right.$ ,$\left.{ }^{\circ} \mathrm{C}\right)$ for the Chamaedaphne, Ledum and Eriophorum-dominated communities during the 2014 measurement period. 


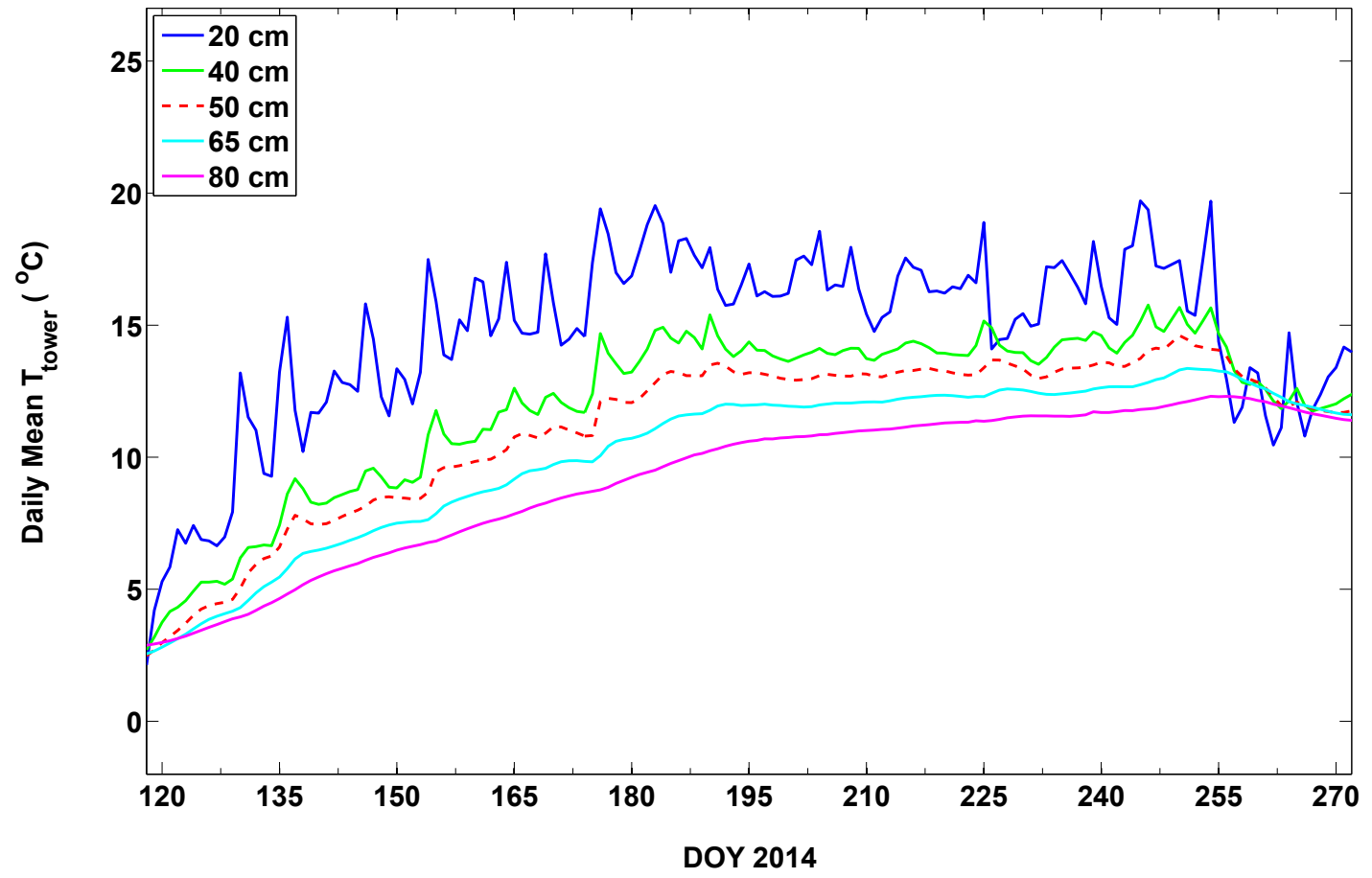

Figure 4-4: Daily mean peat temperature at the tower site $\left(\mathrm{T}_{\text {tower }},{ }^{\circ} \mathrm{C}\right)$ measured at 20,40 , 50,65 , and $80 \mathrm{~cm}$ below peat surface during the 2014 measurement period. 


\subsection{Methane fluxes}

The Chamaedaphne-dominated autochamber community had the lowest mean daily $\mathrm{CH}_{4}$ emissions compared to the Ledum-and Eriophorum-dominated communities (Figure 4-5). The Eriophorum community had the most temporally variable fluxes and by late July ( DOY 210$)$ this community represented a $\mathrm{CH}_{4}$ emission hot spot. The Ledum and Eriophorum communities' emissions demonstrated a clear seasonal increase to roughly mid-July ( $\sim$ DOY 195$)$ after which emission rates remained high until midSeptember ( DOY 255). In contrast, the Chamaedaphne community’s emissions increased more modestly with fluxes remaining relatively small. The manual static chamber sampling days, indicated by the open black circles in Figure 4-5, were representative of the overall trends for the Chamaedaphne and Ledum communities.

By splitting the season into late spring, early summer, mid-summer and late summer periods, differences in $\mathrm{CH}_{4}$ fluxes between communities were apparent (Table 4-1). In particular, by mid- to late-summer, the Ledum and Eriophorum communities had mean daily $\mathrm{CH}_{4}$ flux values that were at least 3 times greater than Chamaedaphne fluxes. 


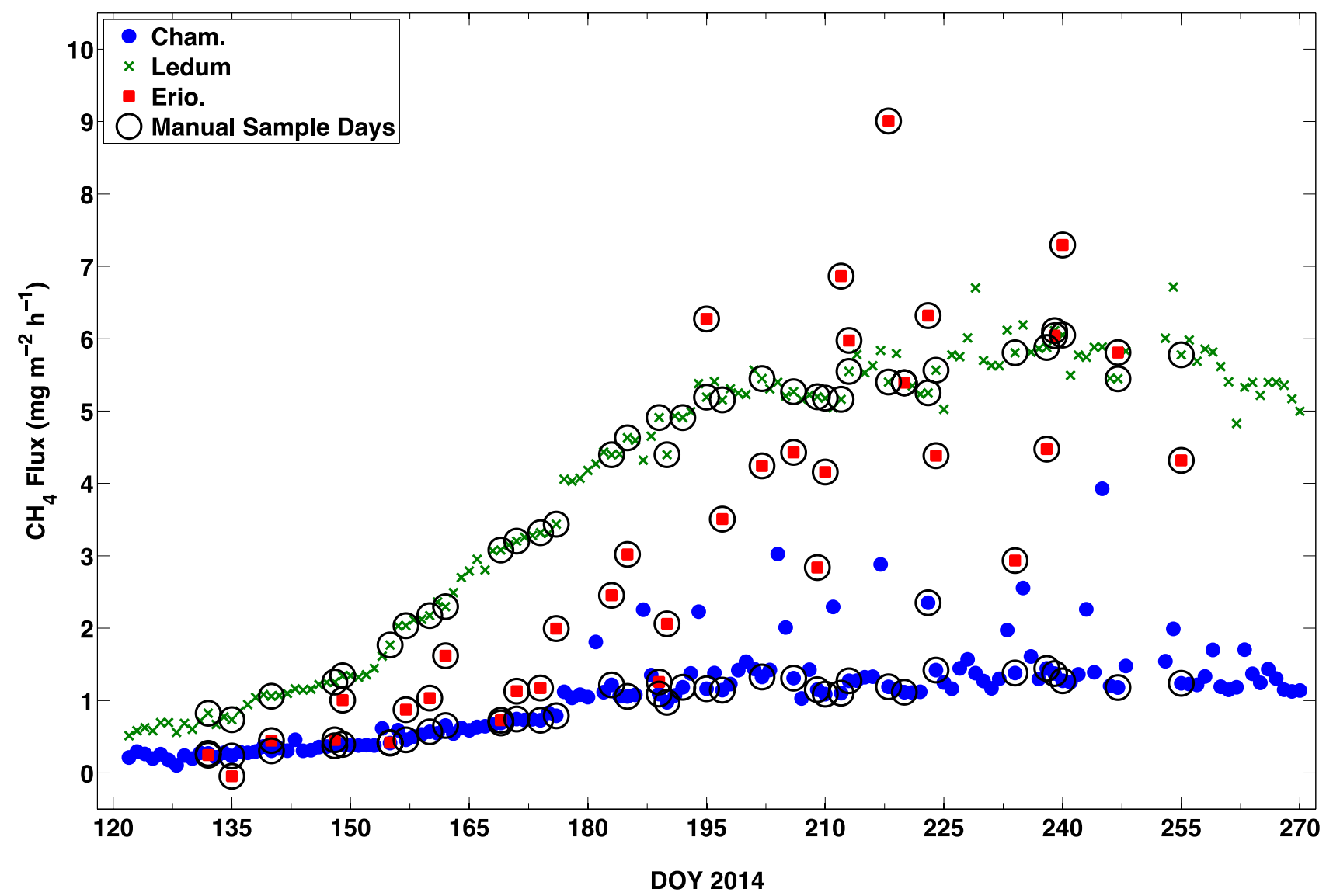

Figure 4-5: Mean daily $\mathrm{CH}_{4}$ flux $\left(\mathrm{mg} \mathrm{m}^{-2} \mathrm{~h}^{-1}\right)$ for Chamaedaphne, Ledum and Eriophorum-dominated communities at Mer Bleue during the 2014 measurement period (DOY 120-270). Open circles indicate days when manual static chamber flux sampling measurements were collected at the Eriophorum community chambers. 
Table 4-1: Comparison of mean daily $\mathrm{CH}_{4}$ flux, water table (WT) and $50 \mathrm{~cm}$ peat temperature at the tower site $\left(\mathrm{T}_{50 \mathrm{~cm}}\right)$ for Chamaedaphne, Ledum and Eriophorumdominated communities at Mer Bleue, 2014. Standard deviation is given in parentheses. $\mathrm{CH}_{4}$ fluxes with different superscripts across a row are significantly different at the $\alpha=0.10$ level when accounting for the chamber as a random effect (or repeated measure) in a mixed model and using Student's $t$-test post-hoc analysis. Similarly, WT depths with different superscripts across a row are significantly different at the $\alpha=0.10$ level when accounting for the chamber as a random effect (or repeated measure) in a mixed model and using Student's $t$-test post-hoc analysis.

\begin{tabular}{|c|c|c|c|c|c|c|}
\hline \multicolumn{2}{|c|}{ Chamaedaphne } & \multicolumn{2}{|c|}{ Ledum } & \multicolumn{2}{|c|}{ Eriophorum } & \multirow[b]{2}{*}{$\mathrm{T}_{50 \mathrm{~cm}}\left({ }^{\circ} \mathrm{C}\right)$} \\
\hline $\begin{array}{c}\mathrm{CH}_{4} \text { Flux } \\
\left(\mathrm{mg} \mathrm{CH}_{4}\right. \\
\left.\mathrm{m}^{-2} \mathrm{~h}^{-1}\right)\end{array}$ & WT $(\mathrm{cm})$ & $\begin{array}{c}\mathrm{CH}_{4} \text { Flux } \\
\left(\mathrm{mg} \mathrm{CH}_{4}\right. \\
\left.\mathrm{m}^{-2} \mathrm{~h}^{-1}\right)\end{array}$ & WT (cm) & $\begin{array}{c}\mathrm{CH}_{4} \text { Flux } \\
\left(\mathrm{mg} \mathrm{CH}_{4}\right. \\
\left.\mathrm{m}^{-2} \mathrm{~h}^{-1}\right)\end{array}$ & WT $(\mathrm{cm})$ & \\
\hline \multicolumn{7}{|c|}{ Whole Period (DOY 132-255, $n=891$ ) } \\
\hline $\begin{array}{l}0.99^{\mathrm{b}} \\
(0.82)\end{array}$ & $\begin{array}{l}36.5^{\mathrm{a}} \\
(6.7)\end{array}$ & $\begin{array}{l}4.13^{\mathrm{a}} \\
(2.13)\end{array}$ & $\begin{array}{l}28.8^{\mathrm{b}} \\
(3.7)\end{array}$ & $\begin{array}{l}2.95^{\mathrm{ab}} \\
(3.57)\end{array}$ & $\begin{array}{l}28.5^{\mathrm{b}} \\
(3.6)\end{array}$ & $11.1(3.0)$ \\
\hline \multicolumn{7}{|c|}{ Late Spring (DOY 132-154, $n=129$ ) } \\
\hline $\begin{array}{l}0.32^{\mathrm{a}} \\
(0.30)\end{array}$ & $\begin{array}{l}35.2^{\mathrm{a}} \\
(7.0)\end{array}$ & $\begin{array}{l}1.04^{\mathrm{b}} \\
(0.39)\end{array}$ & $\begin{array}{l}27.3^{\mathrm{a}} \\
(3.6)\end{array}$ & $\begin{array}{l}0.52^{\mathrm{NA}} \\
(0.51)\end{array}$ & N/A & $6.6(1.8)$ \\
\hline \multicolumn{7}{|c|}{ Early Summer (DOY 155-189, $n=281$ ) } \\
\hline $\begin{array}{l}0.77^{\mathrm{b}} \\
(0.54)\end{array}$ & $\begin{array}{l}36.0^{\mathrm{a}} \\
(7.2)\end{array}$ & $\begin{array}{l}3.21^{\mathrm{a}} \\
(1.26)\end{array}$ & $\begin{array}{l}28.3^{\mathrm{ab}} \\
(4.0)\end{array}$ & $\begin{array}{l}1.39^{\mathrm{b}} \\
(1.45)\end{array}$ & $\begin{array}{l}27.5^{\mathrm{b}} \\
(3.7)\end{array}$ & $11.3(1.2)$ \\
\hline \multicolumn{7}{|c|}{ Mid Summer (DOY 190-221, $n=223$ ) } \\
\hline $\begin{array}{l}1.17^{\mathrm{b}} \\
(0.52)\end{array}$ & $\begin{array}{l}37.0^{\mathrm{a}} \\
(6.5)\end{array}$ & $\begin{array}{l}5.19^{\mathrm{a}} \\
(1.53)\end{array}$ & $\begin{array}{l}29.7^{b} \\
(3.3)\end{array}$ & $\begin{array}{l}4.46^{\mathrm{ab}} \\
(4.15)\end{array}$ & $\begin{array}{l}29.2^{\mathrm{b}} \\
(3.7)\end{array}$ & $13.2(0.2)$ \\
\hline \multicolumn{7}{|c|}{ Late Summer (DOY 222-255, $n=185$ ) } \\
\hline $\begin{array}{l}1.46^{\mathrm{b}} \\
(1.24)\end{array}$ & $\begin{array}{l}37.1^{\mathrm{a}} \\
(6.2)\end{array}$ & $\begin{array}{l}5.74^{\mathrm{a}} \\
(1.82)\end{array}$ & $\begin{array}{l}29.2^{\mathrm{b}} \\
(3.4)\end{array}$ & $\begin{array}{l}5.12^{\mathrm{a}} \\
(4.11)\end{array}$ & $\begin{array}{l}29.2^{\mathrm{b}} \\
(2.8)\end{array}$ & $13.6(0.4)$ \\
\hline
\end{tabular}


From a chamber-specific perspective, $\mathrm{CH}_{4}$ emissions for the Ledum were greatest for autochambers L-A 2 and 3 (Figure 4-6). While classified as part of the Ledum community, L-A 2 and 3 had Eriophorum plants within the chamber collar that constituted $74 \%$ and $68 \%$ of total LAI, respectively. In contrast, autochamber L-A 1 had a tightly constrained $\mathrm{CH}_{4}$ emission pattern with moderate fluxes at about half the emission rates of the L-A 2 and 3 autochambers. E-M 1 was the driver of the highest daily Eriophorum fluxes, while the other two Eriophorum plots were characterized by less frequently elevated flux values. Autochambers C-A 1, 2, and 3, predominantly composed of Chamaedaphne shrubs, had the lowest $\mathrm{CH}_{4}$ emissions despite sporadic higher flux events from C-A 1. While these nine chambers were selected from a relatively small sampling area within the peatland, the spatial variability of summer $\mathrm{CH}_{4}$ fluxes was slightly larger than the temporal variability (Figure 4-6). For example, for any given manual flux sampling date, the coefficient of variation ranged from $52-102 \%$ (as a measure of spatial variation), while the coefficient of variation ranged from $28-87 \%$ for a given chamber across all 36 sampling dates (as a measure of temporal variation). Greatest temporal coefficients of variation were associated with the Eriophorum community plots $(73-87 \%)$ compared to the Ledum $(28-49 \%)$ and Chamaedaphne $(45-66 \%)$ plots. 


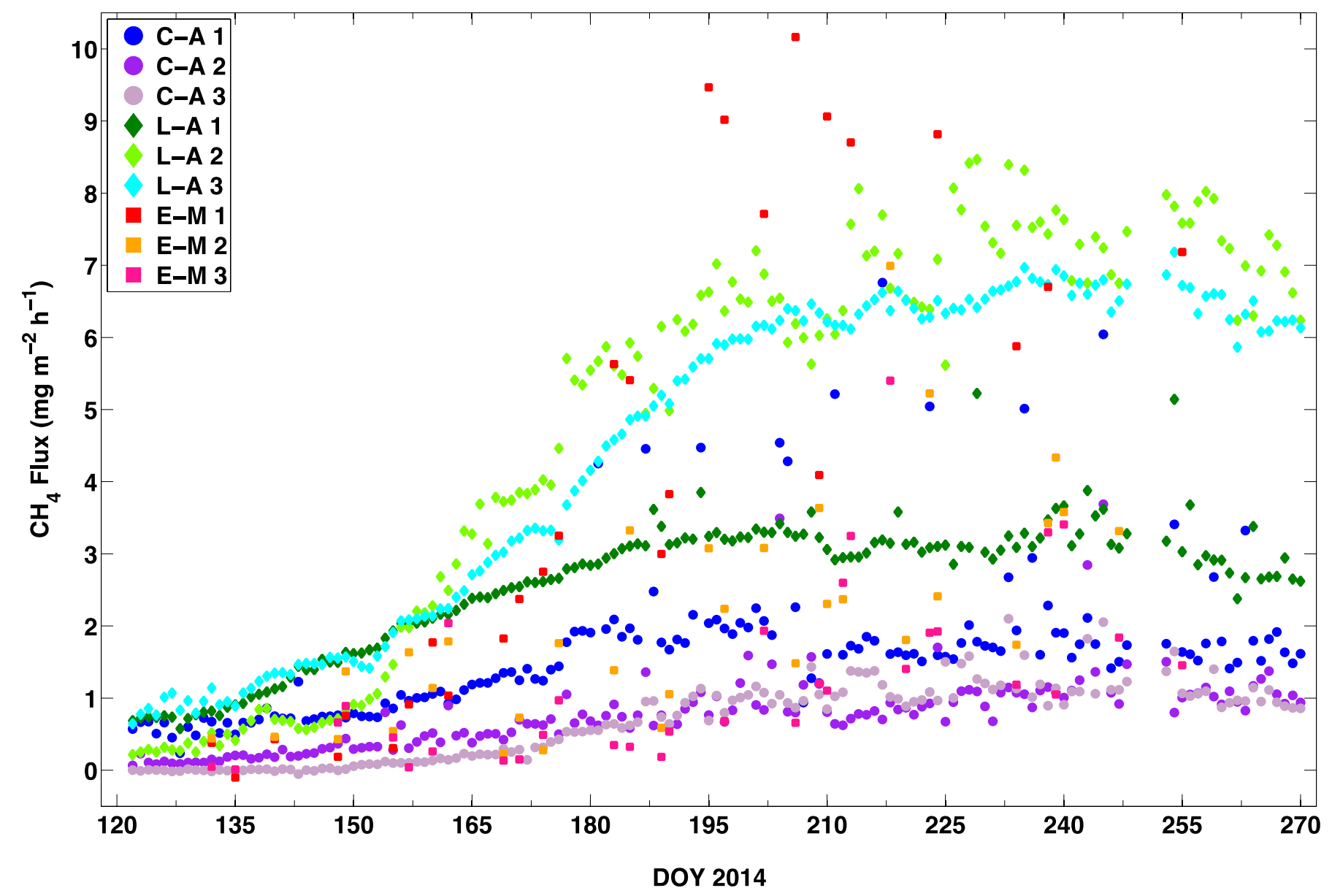

Figure 4-6: Mean daily $\mathrm{CH}_{4}$ flux ( $\left.\mathrm{mg} \mathrm{m}^{-2} \mathrm{~h}^{-1}\right)$ emitted from 3 Chamaedaphne-dominated autochambers (C-A 1, 2, 3) (circles), 3 Ledum-dominated autochambers (L-A 1, 2, 3) (diamonds) and 3 Eriophorum-dominated manual chambers (E-M 1, 2, 3) (squares) at Mer Bleue during the 2014 measurement period (DOY 120-270). 
To better understand the factors influencing spatial and temporal variations in $\mathrm{CH}_{4}$ emissions, the $\log$ transform of $\mathrm{CH}_{4}$ fluxes for manually sampled days were analyzed using a mixed model with community as a fixed effect, chamber as a random effect (to account for repeated measures on the same location over time) and with the following variables as covariates: barometric pressure, $10 \mathrm{~cm}$ peat temperature and WT from each chamber, and $50 \mathrm{~cm}$ peat temperature from the tower location. There was no statistically significant effect of $10 \mathrm{~cm}$ peat temperature as a covariate of $\mathrm{CH}_{4}$ fluxes $(\mathrm{F}(1,794)=2.6170, p=0.1061)$. For example, the Chamaedaphne community plots' 10 $\mathrm{cm}$ peat temperatures varied greatly while there was a relatively restricted range of low $\mathrm{CH}_{4}$ fluxes (Figure 4-7). There was a smaller temperature range and wider range of measured $\mathrm{CH}_{4}$ fluxes for the Ledum community. The Eriophorum community demonstrated greatest variability among chambers in both temperature and $\mathrm{CH}_{4}$ fluxes with greatest fluxes for E-M 1 despite little temperature variation at $10 \mathrm{~cm}$ while E-M 2 reached the highest temperatures but did not produce the greatest $\mathrm{CH}_{4}$ fluxes. The day-today variation in $10 \mathrm{~cm}$ peat temperature obscures the relationship with $\mathrm{CH}_{4}$ flux, such that peat temperature at $10 \mathrm{~cm}$ depth is not useful for analyzing $\mathrm{CH}_{4}$ flux patterns (Figure 4-7). However, deeper peat temperatures $40-50 \mathrm{~cm}$ below the surface have been successfully applied in an examination of controls on $\mathrm{CH}_{4}$ emissions (Moore et al. 2011, Lai et al. 2014a). There was a statistically significant effect of $50 \mathrm{~cm}$ peat temperature $(\mathrm{F}(1,791.8)=523.8658, p<0.0001)$ with a significant interaction effect of vegetation community and $50 \mathrm{~cm}$ peat temperature $(\mathrm{F}(2,791.1)=62.7842, p<0.0001)$. There was a positive relationship between $50 \mathrm{~cm}$ peat temperature and $\mathrm{CH}_{4}$ flux (Figure 4-8) suggesting that peat temperature near the WT may be an important environmental control 
on $\mathrm{CH}_{4}$ emissions although the relationship between $\mathrm{CH}_{4}$ flux and $50 \mathrm{~cm}$ peat temp varies among the vegetative communities.

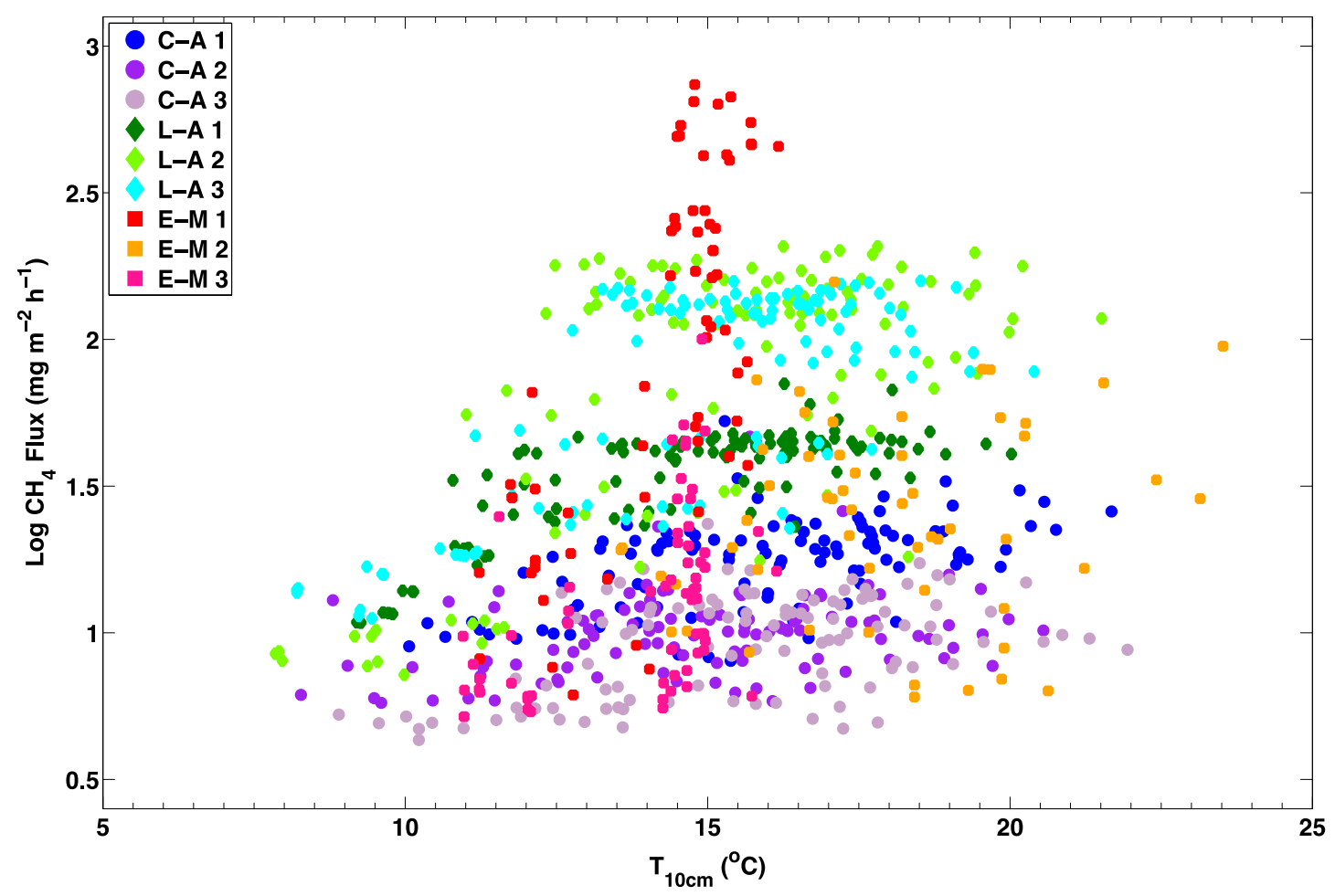

Figure 4-7: The relationship between $10 \mathrm{~cm}$ peat temperature $\left(\mathrm{T}_{10 \mathrm{~cm}},{ }^{\circ} \mathrm{C}\right)$ and $\log \mathrm{CH}_{4}$ flux $\left(\mathrm{mg} \mathrm{m}^{-2} \mathrm{~h}^{-1}\right)$ emitted from 3 Chamaedaphne-dominated autochambers (C-A 1, 2, 3) (circles), 3 Ledum-dominated autochambers (L-A 1, 2, 3) (diamonds) and 3 Eriophorumdominated manual chambers (E-M 1, 2, 3) (squares) at Mer Bleue for manual sampling day data (DOY 132-255). 
- C-A 1 - C-A 2 - C-A 3 - L-A 1 - L-A 2 - L-A 3 - E-M 1 " E-M 2 - E-M 3
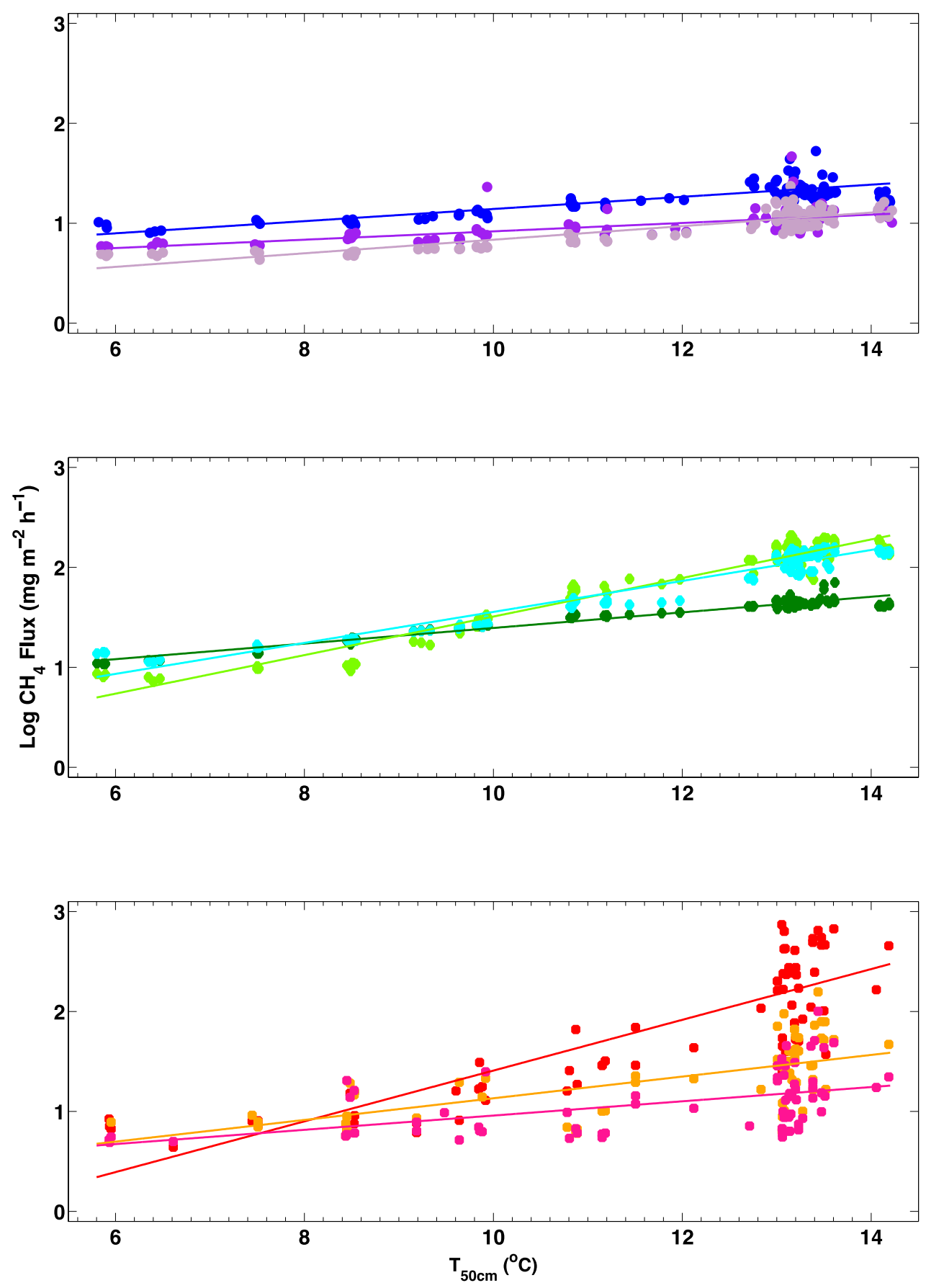

Figure 4-8: The relationship between $50 \mathrm{~cm}$ peat temperature $\left(\mathrm{T}_{50 \mathrm{~cm}},{ }^{\circ} \mathrm{C}\right)$ and $\log \mathrm{CH}_{4}$ flux $\left(\mathrm{mg} \mathrm{m}^{-2} \mathrm{~h}^{-1}\right)$ emitted from 3 Chamaedaphne-dominated autochambers (C-A 1, 2, 3) (circles), 3 Ledum-dominated autochambers (L-A 1, 2, 3) (diamonds) and 3 Eriophorumdominated manual chambers (E-M 1, 2, 3) (squares) at Mer Bleue for manual sampling day data (DOY 132-255). 
Overall, as WT rose, $\mathrm{CH}_{4}$ flux increased when examining all daily chamber flux values (Figure 4-9) and all seasonal averages (Figure 4-10). As a covariate, WT had a significant relationship with $\mathrm{CH}_{4}$ fluxes for manual sampling day data $(\mathrm{F}(1,793.8)=5.7958, p=0.0163)$. For the seasonal averages, the significant relationship between $\log \mathrm{CH}_{4}$ flux and chamber-specific WT is $2.435 \mathrm{mg} \mathrm{m}^{-2} \mathrm{~h}^{-1}+0.03162$ (WT) $\mathrm{mg}$ $\mathrm{m}^{-2} \mathrm{~h}^{-1} \mathrm{~cm}^{-1}\left(F(1,816)=169.77, p<0.001, \mathrm{R}^{2}=0.172\right)$.

However, for a given chamber, there was little relationship with WT, which was expected given the small range in WT variation through the growing season. As a result, microtopography effects on WT drove the spatial variations observed in Figure 4-9 and Figure 4-10. For example, C-A 2 (a Chamaedaphne shrub hummock) had the lowest seasonal WT and lowest $\mathrm{CH}_{4}$ fluxes, while L-A 3 and E-M 1 had WT closer to the surface and produced some of the largest $\mathrm{CH}_{4}$ fluxes (Figure 4-10). 


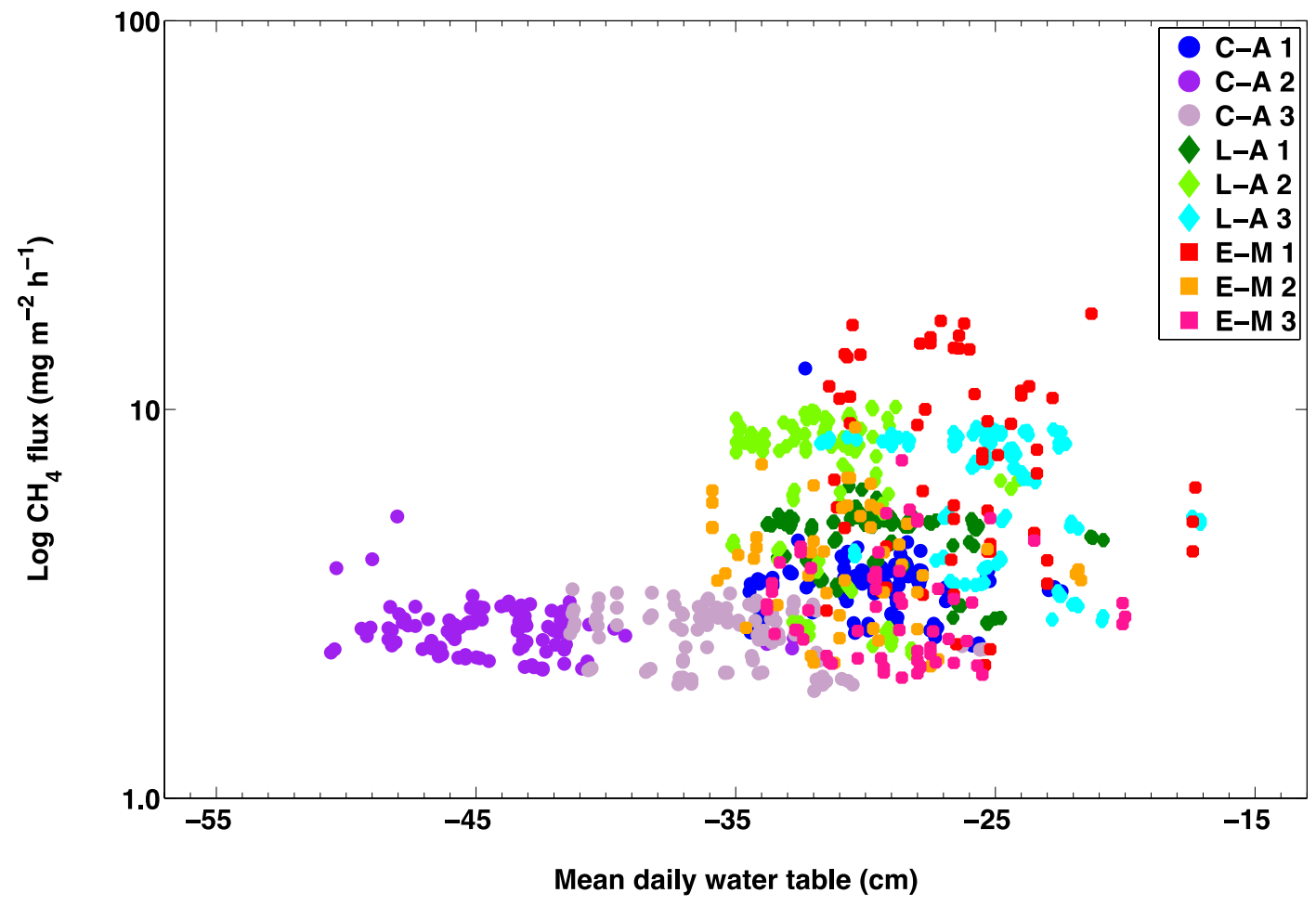

Figure 4-9: Relationship between mean depth to water table $(\mathrm{cm})$ and $\log \mathrm{CH}_{4}$ flux $(\mathrm{mg}$ $\mathrm{m}^{-2} \mathrm{~h}^{-1}$ ) from 3 Chamaedaphne-dominated autochambers (C-A 1, 2, 3) (circles), 3 Ledum-dominated autochambers (L-A 1, 2, 3) (diamonds) and 3 Eriophorum-dominated manual chambers (E-M 1, 2, 3) (squares) at Mer Bleue for manual static chamber sampling days (DOY 132-255) during the 2014 measurement period. 


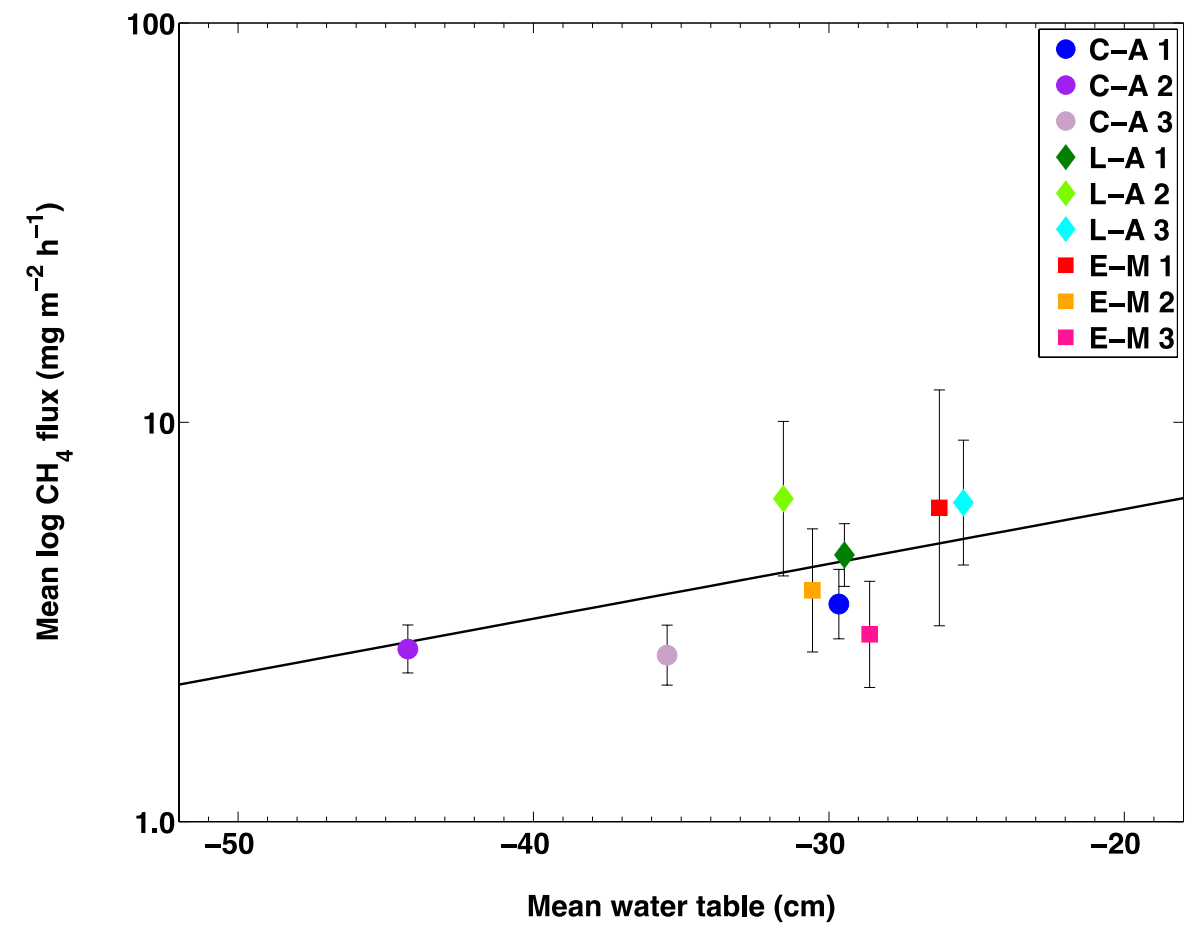

Figure 4-10: Relationship between mean seasonal depth to water table $(\mathrm{cm})$ and mean $( \pm \mathrm{SD})$ seasonal $\log \mathrm{CH}_{4}$ flux $\left(\mathrm{mg} \mathrm{m}^{-2} \mathrm{~h}^{-1}\right)$ from 3 Chamaedaphne-dominated autochambers (C-A 1, 2, 3) (circles), 3 Ledum-dominated autochambers (L-A 1, 2, 3) (diamonds) and 3 Eriophorum-dominated manual chambers (E-M 1, 2, 3) (squares) at Mer Bleue for manual static chamber sampling days (DOY 132-255) 2014. The solid black line shows the linear regression calculated to predict $\log \mathrm{CH}_{4}$ flux based on mean daily water table, where predicted $\log \mathrm{CH}_{4}$ flux is equal to $2.435+0.03162$ (WT) $\mathrm{mg} \mathrm{m}^{-2}$ $\mathrm{h}^{-1}$ when WT is measured in $\mathrm{cm}$ from the peat surface at each chamber.

\subsection{Redox potential measurements}

Examples of redox potential measurements recorded at E-M 1 and E-M 2 are presented in Figure 4-11 and Figure 4-12 respectively. As the boundary between reduction and oxidation conditions is controlled by the position of the WT, the mean daily depth to WT is important to consider. Both chambers had WT below $20 \mathrm{~cm}$ for the late summer-fall sampling period. This is reflected by the average standardized redox 
potential value of $\sim 600 \mathrm{mV}$ at $20 \mathrm{~cm}$, which indicates aerated conditions and the predominance of $\mathrm{O}_{2}$ (Table 2-1). In both of these cases, redox potential reached the most negative values at a depth of $40 \mathrm{~cm}$ - the depth closest to but still below the WT. At E-M 1, the $40 \mathrm{~cm}$ Eh value of $-200 \mathrm{mV}$ suggests the activity of methanogens for the reduction of $\mathrm{CO}_{2}$ to $\mathrm{CH}_{4}$. At E-M 2, the redox potential at $40 \mathrm{~cm}$ is similar to that at 60 and $80 \mathrm{~cm}$ $(-100$ to $0 \mathrm{mV})$, suggesting a greater proportion of alternate terminal electron acceptors higher up the cascade of redox pairs in the soil, such as sulfate $\left(\mathrm{SO}_{4}{ }^{2-}\right)$ and ferric iron $\left(\mathrm{Fe}^{3+}\right)($ Table 2-1).

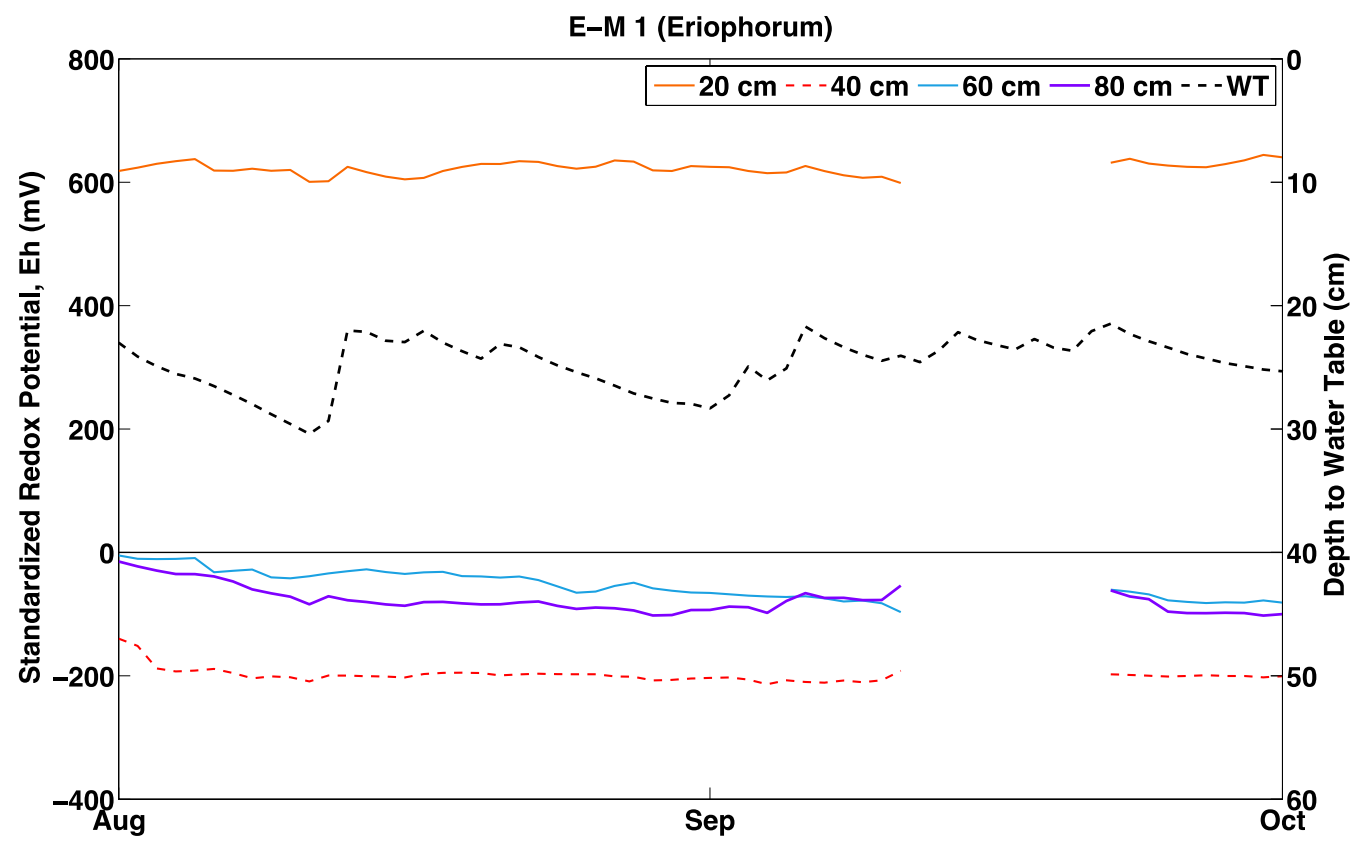

Figure 4-11: Mean daily redox potential $(\mathrm{mV})$ referenced to $\mathrm{Ag} / \mathrm{AgCl}$ reference electrode with $3 \mathrm{M} \mathrm{KCl}$ filling solution and corrected for $\mathrm{pH}$ of 4 . Sampled at chamber E-M 1 (Eriophorum) for peat depths of 20cm, $40 \mathrm{~cm}, 60 \mathrm{~cm}$, and $80 \mathrm{~cm}$ at Mer Bleue, 2014. Mean daily depth to water table $(\mathrm{cm})$ is shown for reference (dotted black line) on the secondary y-axis. 


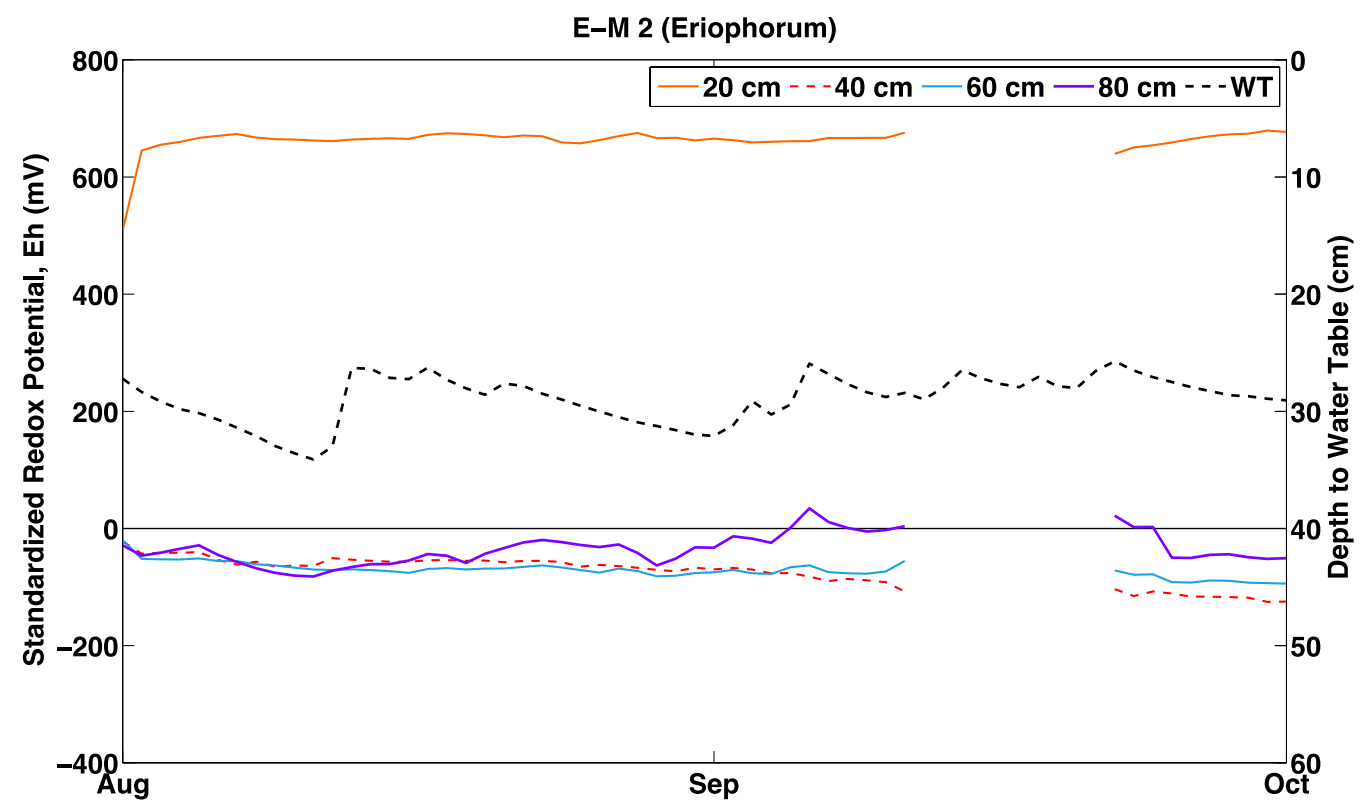

Figure 4-12: Mean daily redox potential $(\mathrm{mV})$ referenced to $\mathrm{Ag} / \mathrm{AgCl}$ reference electrode with $3 \mathrm{M} \mathrm{KCl}$ filling solution and corrected for $\mathrm{pH}$ of 4 . Sampled at chamber E-M 2 (Eriophorum) for peat depths of 20cm, $40 \mathrm{~cm}, 60 \mathrm{~cm}$, and $80 \mathrm{~cm}$ at Mer Bleue, 2014. Mean daily depth to water table $(\mathrm{cm})$ is shown for reference (dotted black line) on the secondary y-axis. 


\subsection{Pore water analyses}

For temporal pore water analyses, DOC $\left(\mathrm{mg} \mathrm{L}^{-1}\right)$, TDN $\left(\mathrm{mg} \mathrm{L}^{-1}\right), \mathrm{SUVA}_{254}\left(\mathrm{~L} \mathrm{~m}^{-1}\right.$ $\mathrm{mg}^{-1} \mathrm{DOC}$ ) and $\mathrm{C} / \mathrm{N}$ ratio were averaged across all chambers for four sampling depths and presented in Figure 4-13. There was an increasing seasonal concentration of DOC and TDN observed in pore water (Figure 4-13). When DOC concentrations were lowest at the beginning of the summer, $\mathrm{SUVA}_{254}$ was at its highest.

The pore water $\mathrm{C} / \mathrm{N}$ ratio did not have as much seasonal variation as both $\mathrm{DOC}$ and TDN increased throughout the summer, yet it did appear to mimic the variation in peat $\mathrm{C} / \mathrm{N}$ ratio, which decreases with depth (Hornibrook et al. 2000b, Malmer \& Wallén 2004, Rydin \& Jeglum 2013, Wang et al. 2015). By constructing the same figure using data from Eriophorum plots only (Figure 4-14) the patterns have much greater variation over the season and with depth. In addition, the trend for these variables in the Eriophorum plots at $50 \mathrm{~cm}$ did not clearly increase or decrease over the season. 


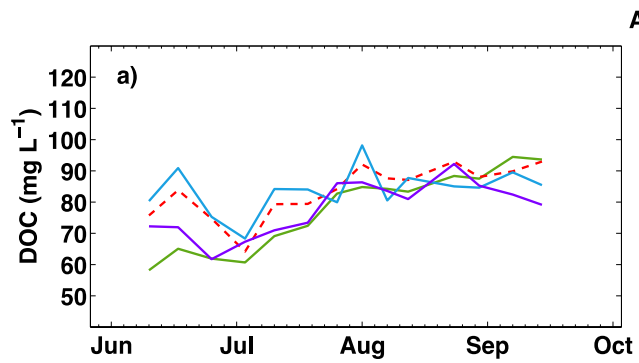

All Chambers
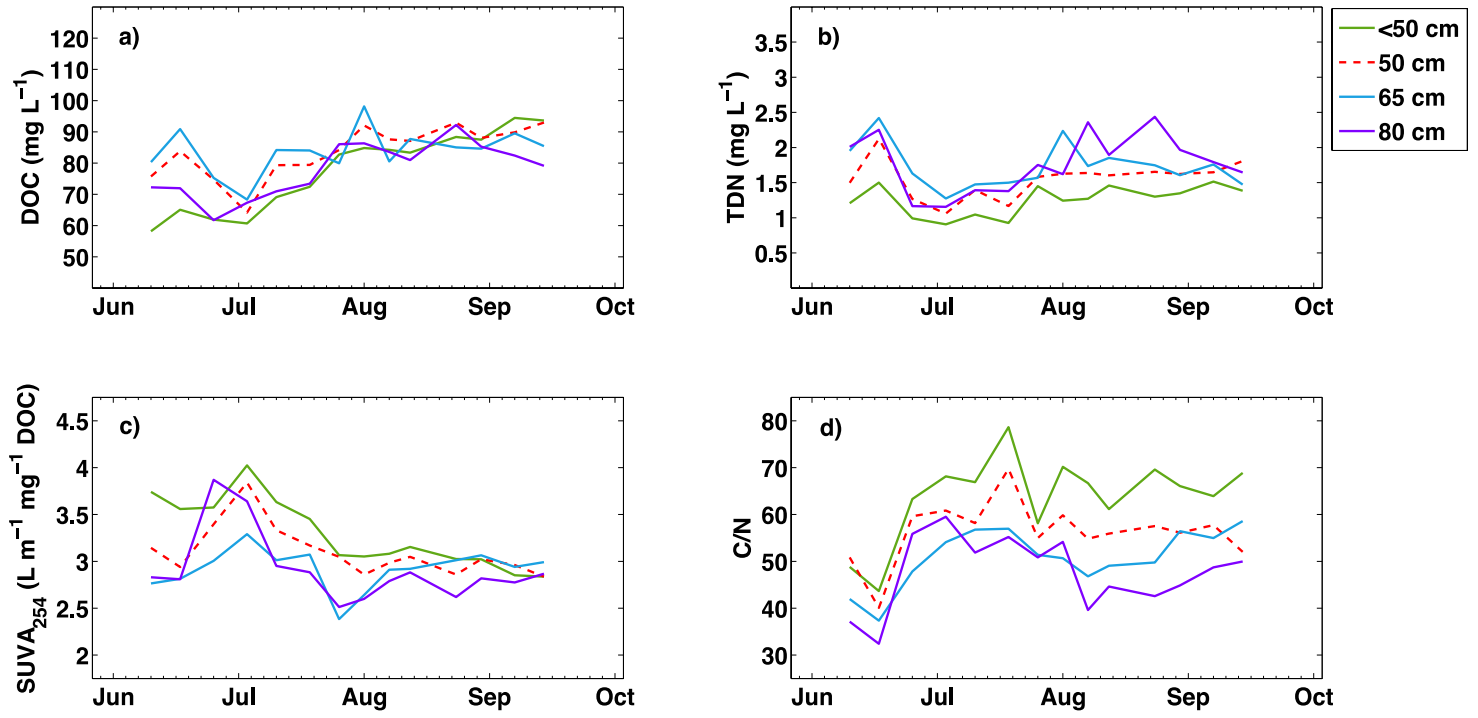

Figure 4-13: Mean daily (a) dissolved organic carbon (DOC, $\mathrm{mg} \mathrm{L}^{-1}$ ), (b) total dissolved nitrogen (TDN, mg L ${ }^{-1}$ ), (c) specific ultraviolet absorbance at $254 \mathrm{~nm}\left(\mathrm{SUVA}_{254}, \mathrm{~L} \mathrm{~m}^{-1}\right.$ $\left.\mathrm{mg}^{-1} \mathrm{DOC}\right)$, and (d) carbon to nitrogen ratio $(\mathrm{C} / \mathrm{N})$ for all chambers at various depths during the 2014 measurement period. 

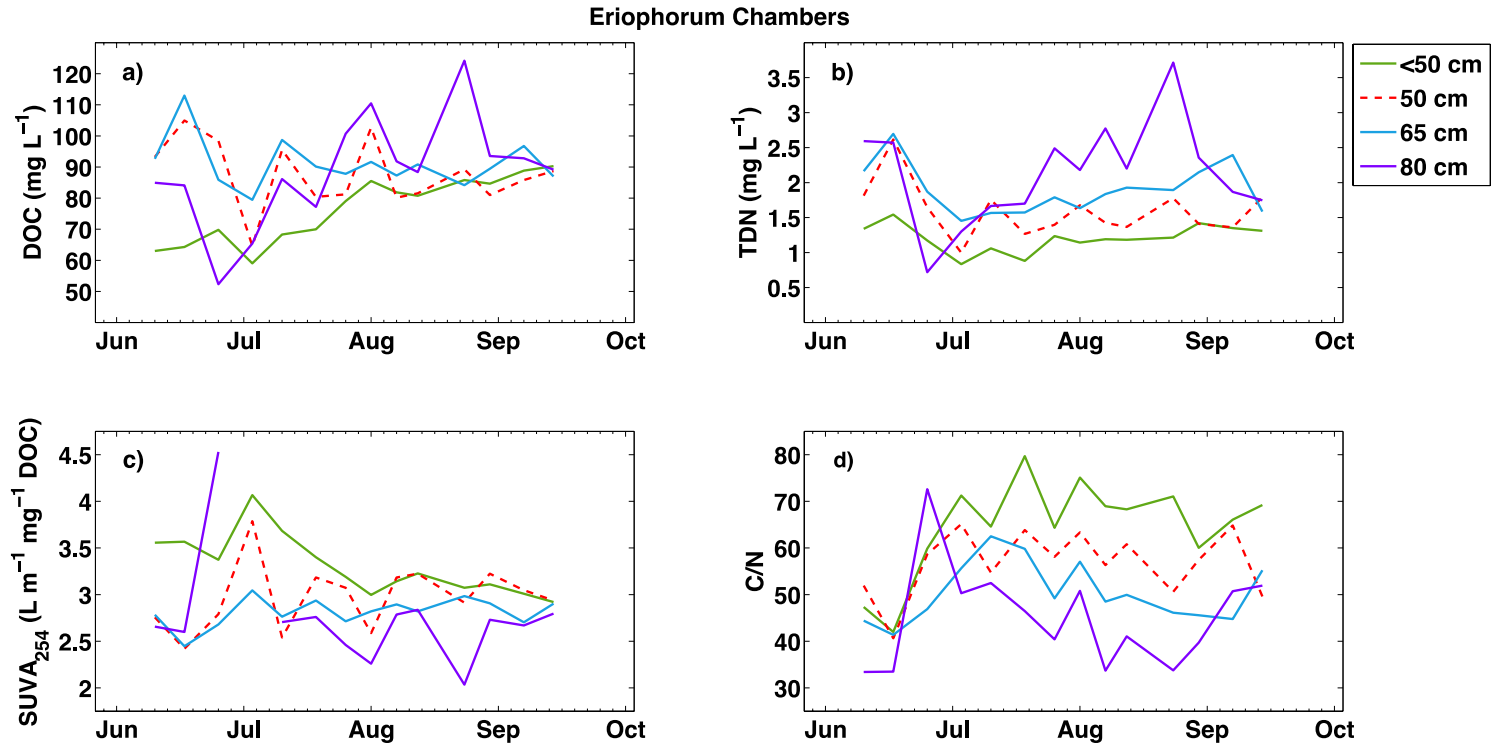

Figure 4-14: Mean daily (a) dissolved organic carbon (DOC, $\mathrm{mg} \mathrm{L}^{-1}$ ), (b) total dissolved nitrogen (TDN, mg L ${ }^{-1}$ ), (c) specific ultraviolet absorbance at $254 \mathrm{~nm}\left(\mathrm{SUVA}_{254} \mathrm{~L} \mathrm{~m}^{-1}\right.$ $\left.\mathrm{mg}^{-1} \mathrm{DOC}\right)$, and (d) carbon to nitrogen ratio $(\mathrm{C} / \mathrm{N})$ for Eriophorum-dominated chambers at various depths during the 2014 measurement period. 
Pore water $\mathrm{CH}_{4}$ concentrations generally increased with depth to a peak at $50 \mathrm{~cm}$ during the late summer season. Samples obtained $20 \mathrm{~cm}$ below peat surface, which was in the aerobic zone above the WT, had small, near-ambient $\mathrm{CH}_{4}$ concentrations. However, a few higher $\mathrm{CH}_{4}$ concentrations (in the range of $100-230 \mu \mathrm{mol} \mathrm{L}^{-1}$ ) were observed at 20 $\mathrm{cm}$, particularly for the Chamaedaphne community in late summer. This could provide evidence for ebullition events (Figure 4-15). Pore water $\mathrm{CH}_{4}$ was analyzed using a mixed model with chamber as a random effect and DOC, TDN, depth-specific peat temperature and WT as covariates, and depth and community as fixed effects. There was no statistically significant effect of community $(\mathrm{F}(2,8.53)=1.4098, p=0.2958)$ or sampling depth $(\mathrm{F}(1,445.2)=0.4707, p=0.4930)$ on pore water $\mathrm{CH}_{4}$ concentrations over the entire sampling period (DOY 155-255). However, when only later summer sampling days were considered (DOY 212-255), there was a statistically significant effect of community ( $F(2$, 9.669) $=4.7589, p=0.0364$ ) where Chamaedaphne had significantly higher pore water $\mathrm{CH}_{4}$ concentrations than the Ledum community. 

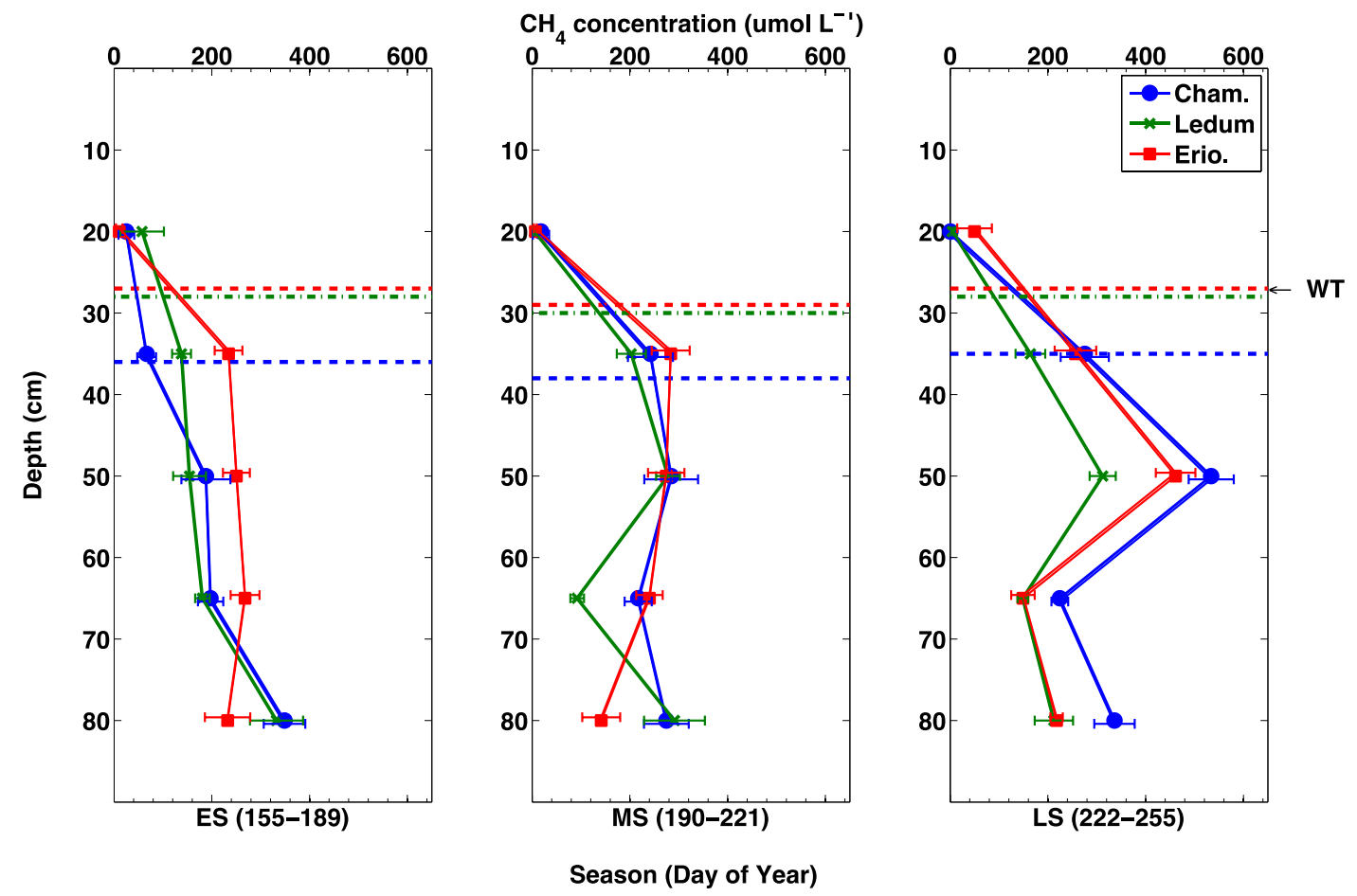

Figure 4-15: Pore water profiles of mean $( \pm \mathrm{SE})$ dissolved $\mathrm{CH}_{4}$ concentrations $\left(\mu \mathrm{mol} \mathrm{L}^{-1}\right)$ for three vegetation communities at Mer Bleue. Depth was measured from peat surface $(\mathrm{cm})$. Horizontal lines indicate mean depth to water table $(\mathrm{cm})$ for each community. Note: ES, early summer (DOY 155-189); MS, mid-summer (DOY 190-221); LS, late summer (DOY 222-255) for the 2014 measurement period. 
Only at $50 \mathrm{~cm}$ was there a tendency for pore water $\mathrm{CH}_{4}$ concentrations to increase through the growing season (Figure 4-16). This trend seemed to be largely driven by several high pore water $\mathrm{CH}_{4}$ concentrations sampled in late August and early September. To further investigate the importance of the $50 \mathrm{~cm}$ depth, $\mathrm{CH}_{4}$ concentrations $\left(\mu \mathrm{mol} \mathrm{L}{ }^{-1}\right)$ at $50 \mathrm{~cm}$ were analyzed on a plot basis (Figure 4-17). Methane concentrations appeared to increase over the summer, but there was large variability among chambers. In particular, C-A 3 fluctuated substantially but reached the highest $50 \mathrm{~cm} \mathrm{CH}_{4}$ concentrations of all chambers by late summer. The least variability among the Ledum chambers was L-A 3. E-M 1 was variable but produced the largest $\mathrm{CH}_{4}$ concentrations among the Eriophorum chambers for most of the summer. Collectively, the largest increase in $\mathrm{CH}_{4}$ concentration at $50 \mathrm{~cm}$ over time was in the Chamaedaphne plots. 


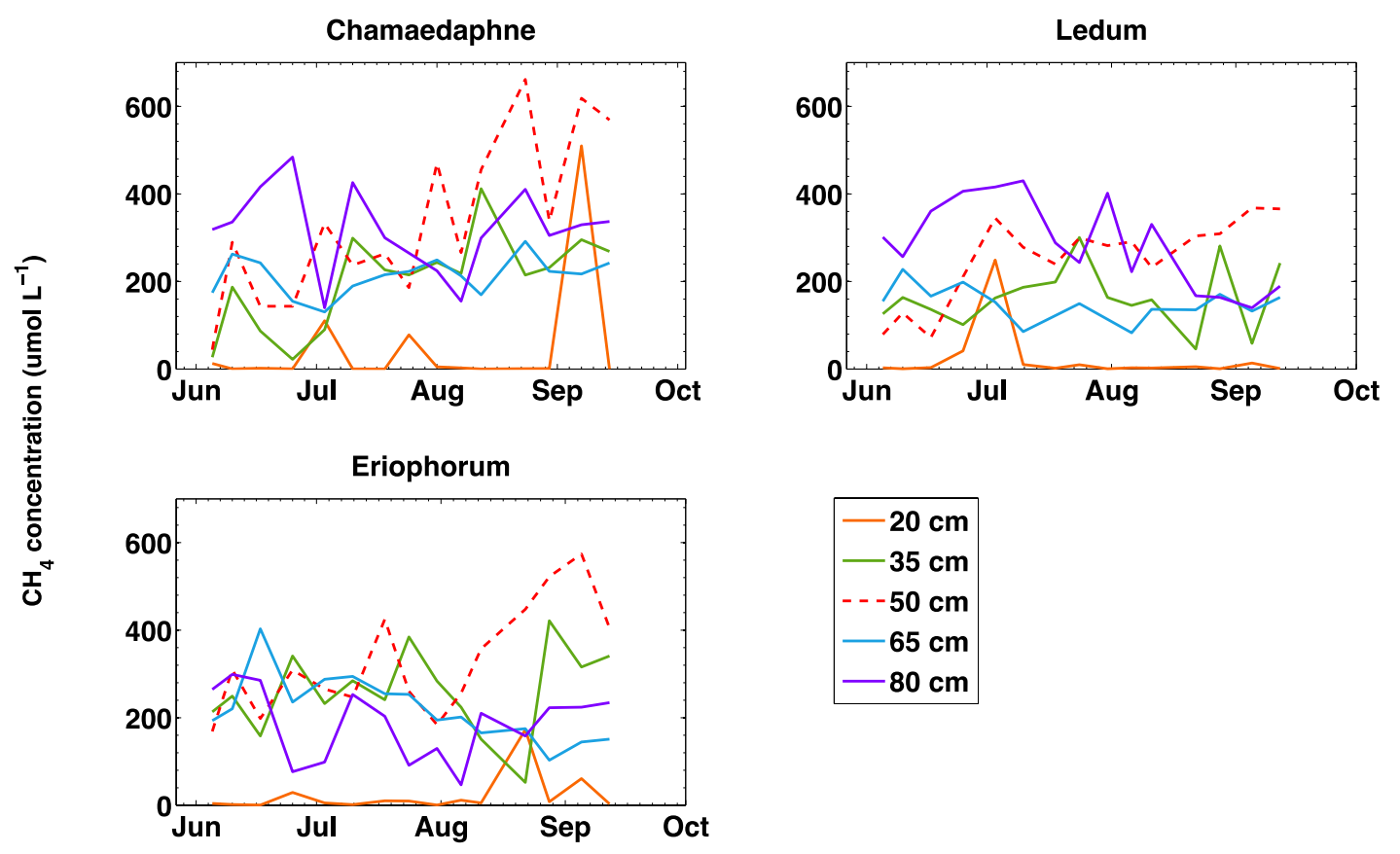

Figure 4-16: Seasonal dissolved pore water $\mathrm{CH}_{4}$ concentrations $\left(\mu \mathrm{mol} \mathrm{L}{ }^{-1}\right)$ at $20,35,50$, 65 and $80 \mathrm{~cm}$ for Chamaedaphne, Ledum and Eriophorum-dominated communities at Mer Bleue during 2014. 

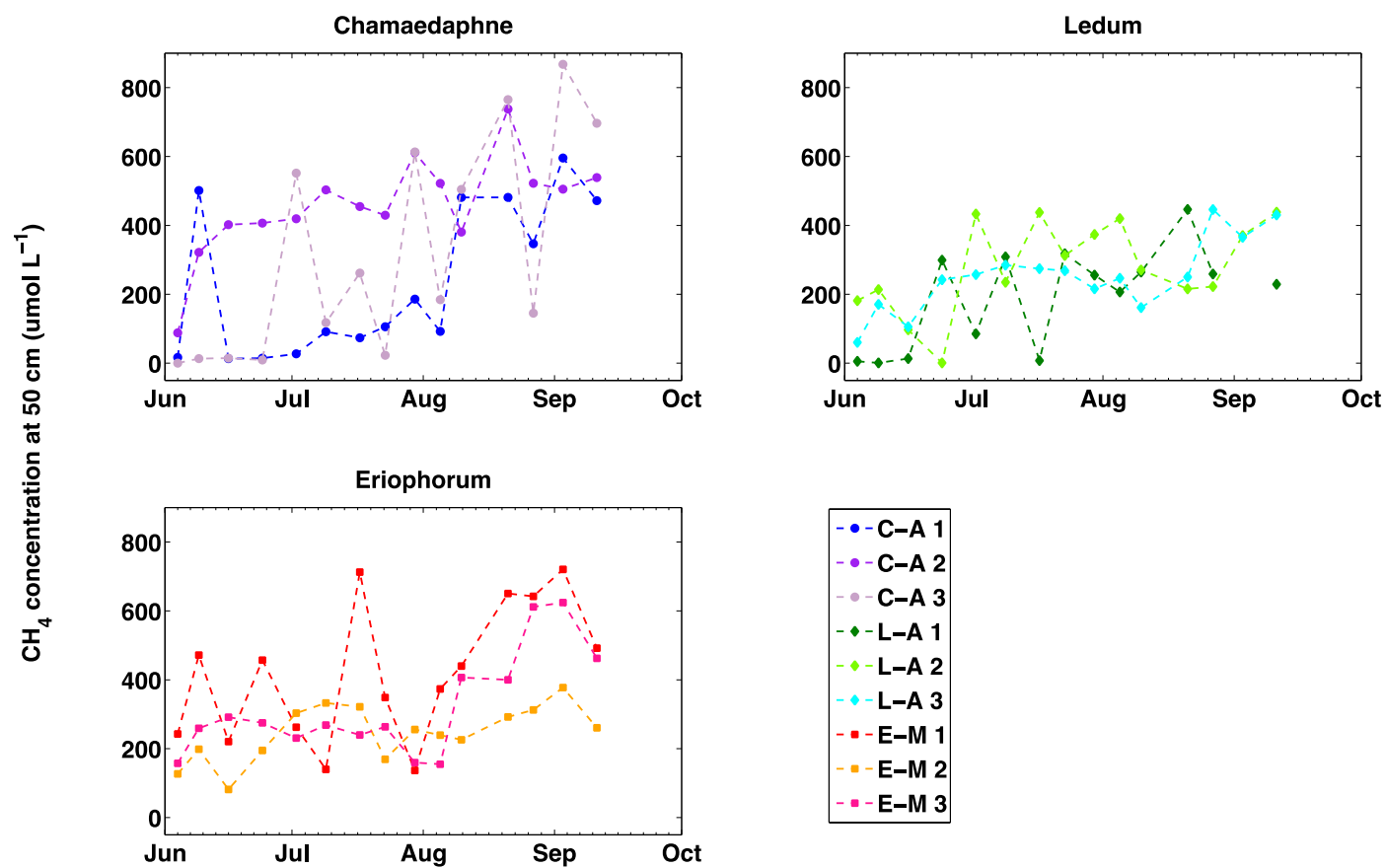

Figure 4-17: Seasonal dissolved pore water $\mathrm{CH}_{4}$ concentrations $\left(\mu \mathrm{mol} \mathrm{L} \mathrm{L}^{-1}\right)$ at $50 \mathrm{~cm}$ depth for 3 Chamaedaphne-dominated autochambers (C-A 1, 2, 3) (circles), 3 Ledumdominated autochambers (L-A 1, 2, 3) (diamonds) and 3 Eriophorum-dominated manual chambers (E-M 1, 2, 3) (squares) at Mer Bleue during the 2014 measurement period. 


\section{5 $\quad \mathrm{CH}_{4}$ production pathway}

$\mathrm{CH}_{4}$ production pathways were investigated using the Keeling Plot approach to discern the dominant $\mathrm{CH}_{4}$ production pathway (Figure 4-18). The $\delta^{13} \mathrm{C}-\mathrm{CH}_{4}$ source signatures were restricted to a narrow range of depleted values $(\sim-81$ to $-71 \%)$ for all chambers. Taking into account the random effect of chamber (as a repeated measure), there was no statistically significant effect of community on $\delta^{13} \mathrm{C}-\mathrm{CH}_{4}$ source signatures $(\mathrm{F}(2,5.668)=0.2107, p=0.8161)$. The $\delta^{13} \mathrm{C}-\mathrm{CH}_{4}$ source signatures for all three communities provided evidence for the $\mathrm{CO}_{2}$ reduction pathway of $\mathrm{CH}_{4}$ production, which produces a relatively ${ }^{13} \mathrm{C}$-depleted signature (-110 to $-60 \%$ ) compared to the acetate fermentation (-65 to $-50 \%$ ) pathway (Whiticar et al. 1986) (Figure 4-18).

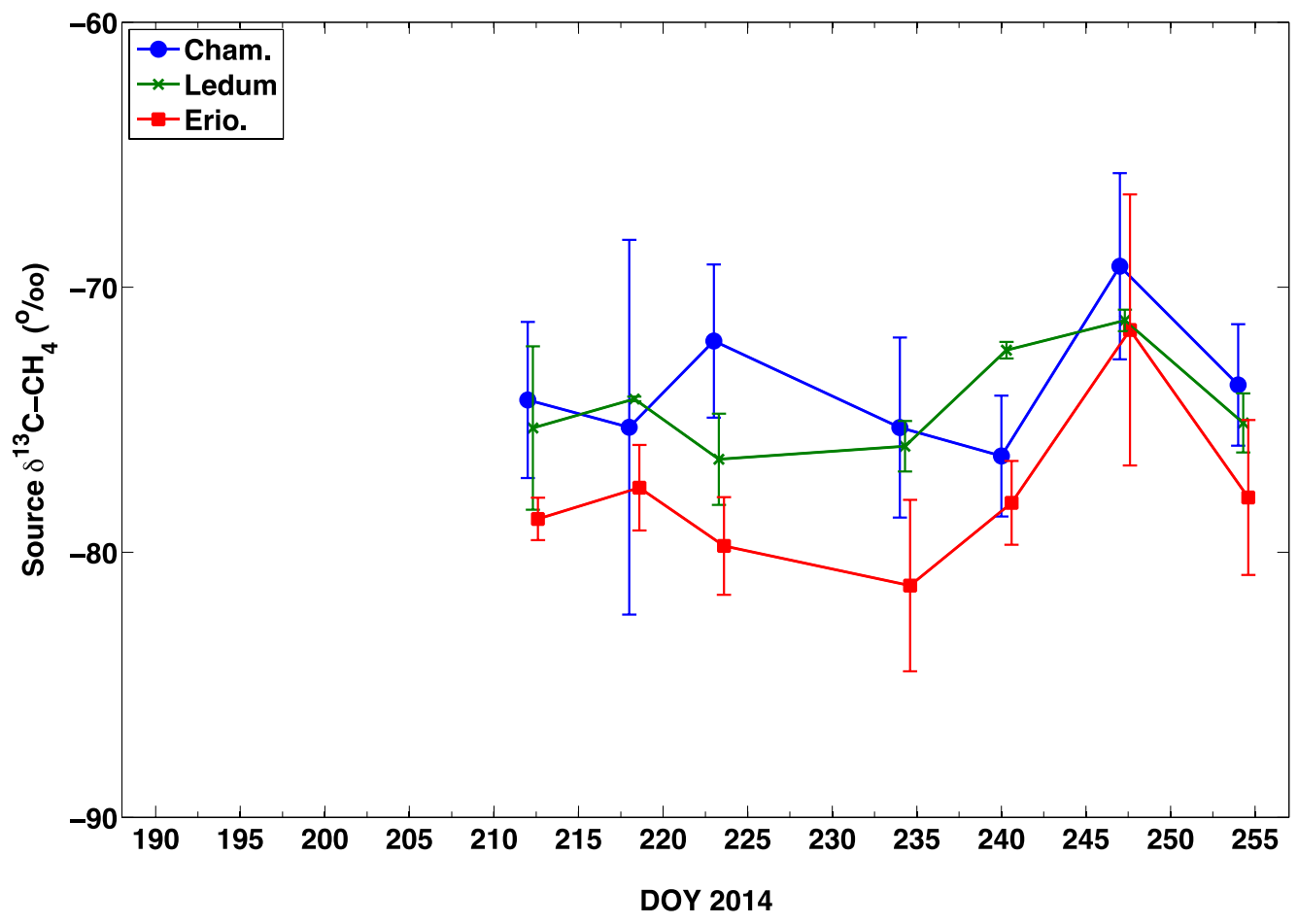

Figure 4-18: Mean $( \pm \mathrm{SD}) \delta^{13} \mathrm{C}-\mathrm{CH}_{4}$ isotopic signatures (\%o) for $\mathrm{CH}_{4}$ emitted from Chamaedaphne, Ledum and Eriophorum-dominated communities at Mer Bleue during the mid- to late-summer 2014 measurement period. 


\subsection{Estimates of seasonal $\mathrm{CH}_{4}$ storage change}

The change in pore water $\mathrm{CH}_{4}$ storage over time was explored with a focus on multiple peat depths and combinations of sampling depths along with different time periods. Week-to-week analyses were confounded by high variability in pore water $\mathrm{CH}_{4}$ concentrations, while the temporal variations in pore water $\mathrm{CH}_{4}$ at $50 \mathrm{~cm}$ dominated the storage term. Changes in storage of $\mathrm{CH}_{4}$ computed using only the $50 \mathrm{~cm}$ depth (over a 15 $\mathrm{cm}$ layer) over the entire pore water sampling period revealed the most distinct differences among communities. C-A 3 (Chamaedaphne) had the largest increase in $\mathrm{CH}_{4}$ storage $\left(0.71 \mathrm{mg} \mathrm{m}^{-2} \mathrm{~h}^{-1}\right)$ at the $50 \mathrm{~cm}$ depth (Figure 4-19). C-A 1 (Chamaedaphne) also had a relatively large increase in $\mathrm{CH}_{4}$ storage $\left(0.44 \mathrm{mg} \mathrm{m}^{-2} \mathrm{~h}^{-1}\right)$. However, the remaining Chamaedaphne autochamber, C-A 2, had only moderate $\mathrm{CH}_{4}$ storage change $\left(0.34 \mathrm{mg} \mathrm{m}^{-}\right.$ $\left.{ }^{2} \mathrm{~h}^{-1}\right)$ in comparison to the other two Chamaedaphne chambers over the season. This chamber's deep WT position ( $\sim 5 \mathrm{~cm}$ below peat surface) and the corresponding thick aerobic peat layer, which provides increased potential for $\mathrm{CH}_{4}$ consumption, likely contributed to this difference. E-M 2 demonstrated the smallest change in $\mathrm{CH}_{4}$ storage $\left(0.16 \mathrm{mg} \mathrm{m}^{-2} \mathrm{~h}^{-1}\right)$. The remaining chambers showed moderate $\mathrm{CH}_{4}$ storage increase over the season ranging from 0.20 to $0.33 \mathrm{mg} \mathrm{m}^{-2} \mathrm{~h}^{-1}$.

A linear relationship between $\mathrm{CH}_{4}$ storage change at $50 \mathrm{~cm}$ and mean $\mathrm{CH}_{4}$ flux for manual sampling days during the pore water collection period was not significant (Figure 4-20) $(\mathrm{r}=-0.4438, \mathrm{~N}=9, \mathrm{p}=0.2315)$. However, an exponential function fit the data (Figure 4-20) $(\mathrm{p}=0.0024)$, reflecting the pattern of greater fluxes with less change in $\mathrm{CH}_{4}$ storage in the pore water. For example, the chamber with the greatest $\mathrm{CH}_{4}$ storage change 
had very low fluxes (C-A 3) and some of the highest emitters (L-A 2, 3) had low $\mathrm{CH}_{4}$ storage change.

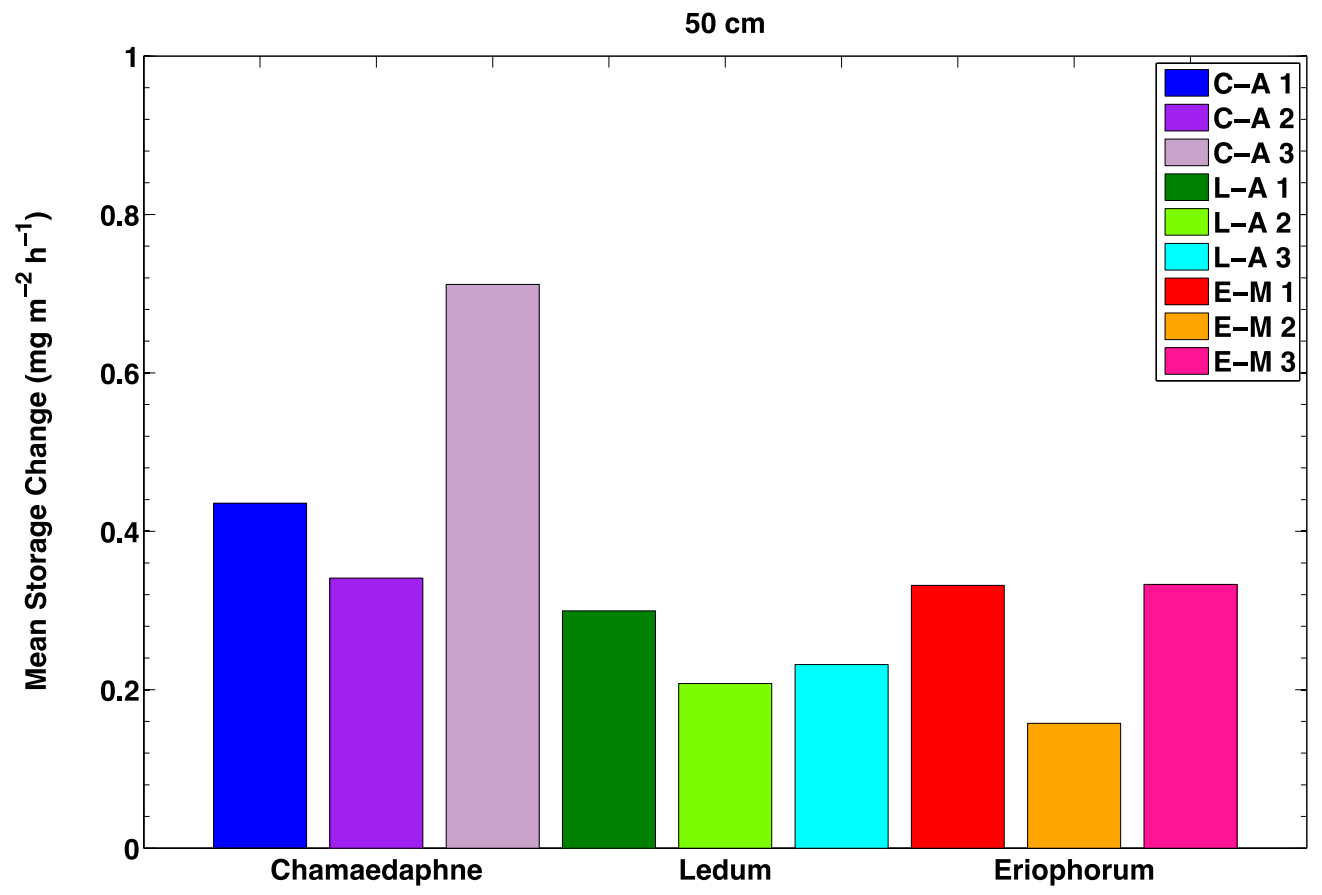

Figure 4-19: Mean $\mathrm{CH}_{4}$ storage change $\left(\mathrm{mg} \mathrm{m}^{-2} \mathrm{~h}^{-1}\right)$ for 3 Chamaedaphne-dominated autochambers (C-A 1, 2, 3), 3 Ledum-dominated autochambers (L-A 1, 2, 3) and 3 Eriophorum-dominated manual chambers (E-M 1,2,3) at the $50 \mathrm{~cm}$ depth $(15 \mathrm{~cm}$ thickness) during the pore water sampling period (DOY 155-255). 


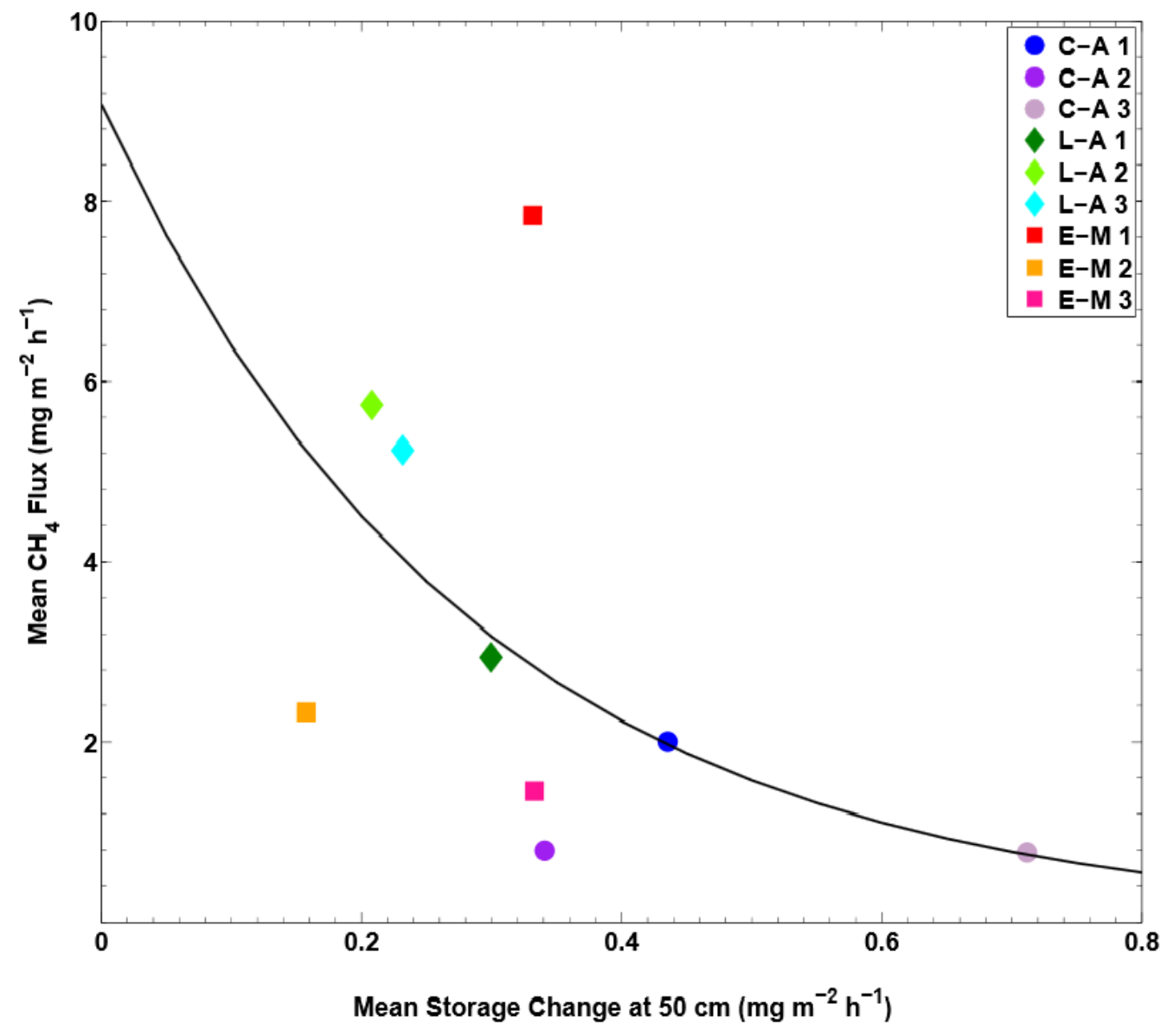

Figure 4-20: Relationship between mean storage change at $50 \mathrm{~cm}\left(\mathrm{mg} \mathrm{m}^{-2} \mathrm{~h}^{-1}\right)$ and mean $\mathrm{CH}_{4}$ flux $\left(\mathrm{mg} \mathrm{m}^{-2} \mathrm{~h}^{-1}\right)$ for 3 Chamaedaphne-dominated autochambers (C-A 1, 2, 3) (circles), 3 Ledum-dominated autochambers (L-A 1, 2, 3) (diamonds) and 3 Eriophorumdominated manual chambers (E-M 1, 2, 3) (squares) at Mer Bleue for manual sampling days during the pore water collection period 2014 (DOY 155-255). The solid black line shows the nonlinear regression calculated to predict mean $\mathrm{CH}_{4}$ flux based on storage change at $50 \mathrm{~cm}$, where predicted mean $\mathrm{CH}_{4}$ flux $\left(\mathrm{mg} \mathrm{m}^{-2} \mathrm{~h}^{-1}\right)$ is equal to $9.08 \times 0.03^{\wedge} \mathrm{S}_{\mathrm{CH}}$ where $\mathrm{S}_{\mathrm{CH} 4}$ is storage change measured in $\mathrm{mg} \mathrm{m}^{-2} \mathrm{~h}^{-1}$. 


\subsection{Relationships among indicators of $\mathrm{CH}_{4}$ production, storage and transport}

Overall, on a plot scale during the mid- to late-summer periods when all variables were available for analysis, vegetation community type can be related to a number of variables associated with the production, storage and transport of $\mathrm{CH}_{4}$ (Figure 4-21 and Table 4-2). Although vegetation classification is subject to the user's classification scheme, Eriophorum vaginatum, as an important species with mechanistic implications to $\mathrm{CH}_{4}$ transport and production, correlated strongly to community type (where Chamaedaphne $=$ community 1, Ledum $=$ community 2 , and Eriophorum $=$ community 3). More Eriophorum was associated with shallower WT, greater $\mathrm{CH}_{4}$ emissions and more depleted $\delta^{13} \mathrm{C}-\mathrm{CH}_{4}$ source signature (Figure 4-21 and Table 4-2). These variables tended to be associated with the first principle component, which explained $38.1 \%$ of the variation in the data (Figure 4-21). However, neither community nor \% LAI attributed to Eriophorum vaginatum (EV\%) correlated with $50 \mathrm{~cm}$ pore water characteristics (Figure 4-21 and Table 4-2). The second principle component explained $28.1 \%$ of the variance and tended to associate with below ground characteristics. For this set of variables, a measure of biomass (LAI-2000) correlated with some of these pore water characteristics (positive correlation with TDN and negative correlation with $\mathrm{C} / \mathrm{N}$ ). Many of these pore water characteristics also closely related to each other. For example, greater TDN was associated with lower $\mathrm{SUVA}_{254}$ and $\mathrm{C} / \mathrm{N}$, as was also demonstrated with the temporal and spatial (depth) trends in Figure 4-13. Only WT weakly correlated with pore water $\mathrm{CH}_{4}$ concentrations $(\mathrm{p}$-value $=0.07)$ with deeper WT having greater $\mathrm{CH}_{4}$ concentrations (characteristic of the non-Eriophorum plots although not correlating to any vegetation metrics). As with previous analyses, there was no significant correlation $(p<0.05)$ 
between $\mathrm{CH}_{4}$ storage change (calculated from pore water $\mathrm{CH}_{4}$ from DOY 155 to 255 ) and any measure of community type or any other variable. However, there was a weak negative relationship $(\mathrm{p}=0.09)$ between storage change and community type, where more sedge has less storage change and a negative relationship between storage change and flux $(\mathrm{p}=0.09)$. Similarly, weak relationships between total LAI (perhaps as a proxy for plant productivity) and pore water characteristics included a negative correlation with DOC $(p=0.08)$ and a positive correlation with SUVA $(p=0.09)$. 


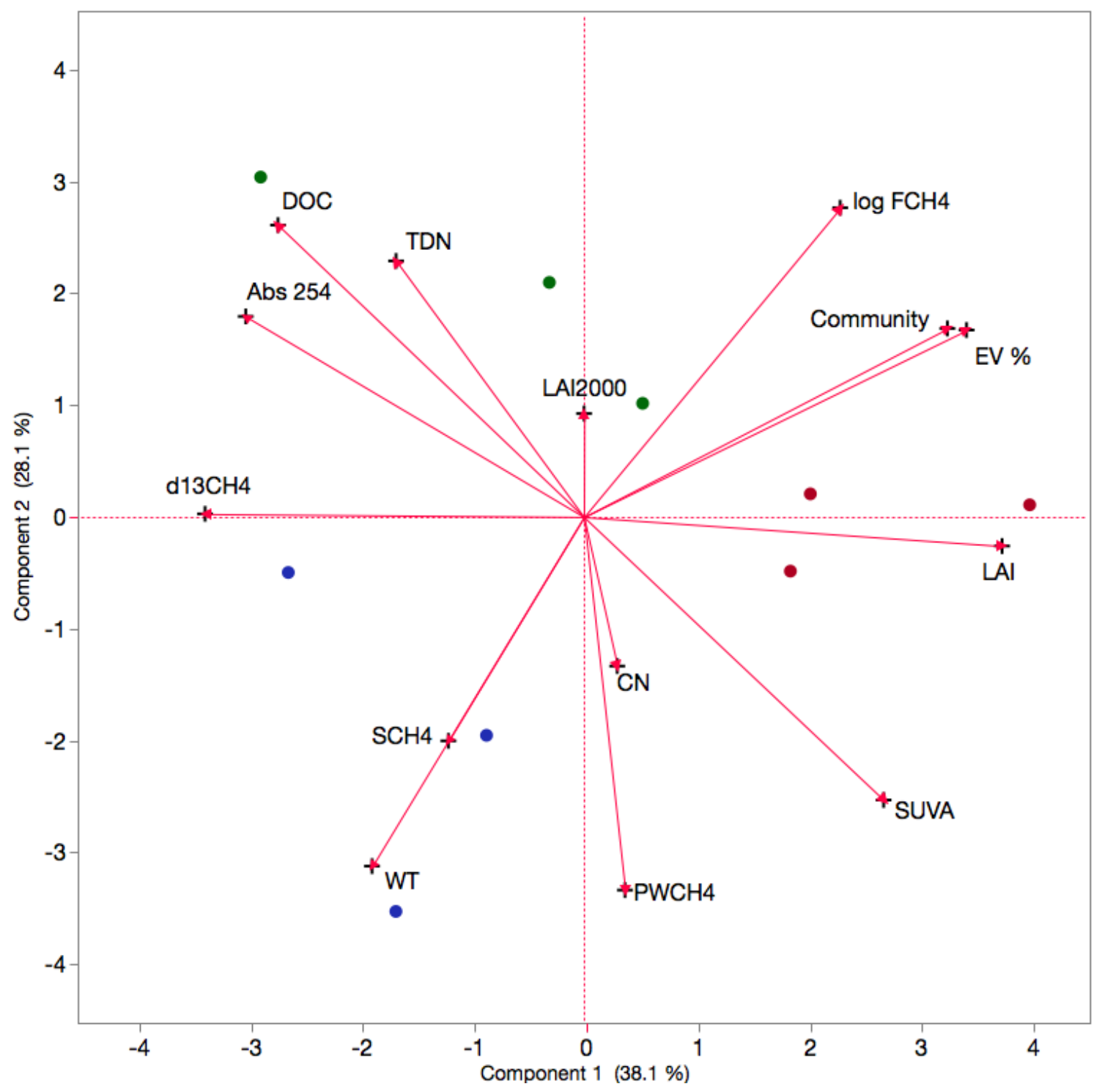

Figure 4-21: Principal component analysis for averaged chamber-specific variables between DOY 212 and 255. $\mathrm{N}=9$. All pore water and temperature variables are from the $50 \mathrm{~cm}$ depth. Variables include: community type, total green hits LAI (LAI), percent LAI attributed to Eriophorum vaginatum (EV \%), total biomass LAI as measured with the LAI-2000 (LAI2000), $\mathrm{CH}_{4}$ flux $\left(\mathrm{F}_{\mathrm{CH}} 4\right)$, storage change of pore water $\mathrm{CH}_{4}\left(\mathrm{~S}_{\mathrm{CH}}\right)$, pore water $\mathrm{CH}_{4}$ concentration $\left(\mathrm{PW}_{\mathrm{CH} 4}\right), \delta^{13} \mathrm{C}-\mathrm{CH}_{4}$ source signature $\left(\delta^{13} \mathrm{C}-\mathrm{CH}_{4}\right)$, water table depth (WT), dissolved organic carbon (DOC), total dissolved nitrogen (TDN), carbon to nitrogen ratio $(\mathrm{CN})$, absorbance at $254 \mathrm{~nm}\left(\mathrm{Abs}_{254}\right)$, and specific ultraviolet absorbance at $254 \mathrm{~nm}\left(\mathrm{SUVA}_{254}\right)$. Chambers are dots and grouped according to community type:

Chamaedaphne $=$ blue, Ledum $=$ green, and Eriophorum $=$ red. 
Table 4-2: Pearson correlations for averaged chamber-specific variables between DOY 212 and 255. All pore water and temperature variables are from the $50 \mathrm{~cm}$ depth. Correlations in bold $(\mathrm{p}<0.05)$ and italics $(\mathrm{p}<0.10)$ are significant. $\mathrm{N}=9$. Variables include: community type, total green hits LAI (LAI), percent LAI attributed to Eriophorum vaginatum (EV \%), total biomass LAI as measured with the LAI-2000 (LAI2000), $\mathrm{CH}_{4}$ flux $\left(\mathrm{F}_{\mathrm{CH}}\right)$, storage change of pore water $\mathrm{CH}_{4}\left(\mathrm{~S}_{\mathrm{CH} 4}\right)$, pore water $\mathrm{CH}_{4}$ concentration $\left(\mathrm{PW}_{\mathrm{CH}}\right)$, $\delta^{13} \mathrm{C}-\mathrm{CH}_{4}$ source signature $\left(\delta^{13} \mathrm{C}-\mathrm{CH}_{4}\right)$, water table depth $(\mathrm{WT})$, dissolved organic carbon (DOC), total dissolved nitrogen (TDN), carbon to nitrogen ratio $(\mathrm{CN})$, absorbance at $254 \mathrm{~nm}\left(\mathrm{Abs}_{254}\right)$, and specific ultraviolet absorbance at $254 \mathrm{~nm}\left(\mathrm{SUVA}_{254}\right)$.

\begin{tabular}{|c|c|c|c|c|c|c|c|c|c|c|c|c|c|c|}
\hline & Community & $\begin{array}{l}\text { LAI- } \\
2000\end{array}$ & LAI & $\begin{array}{c}\text { EV } \\
\% \\
\end{array}$ & WT & DOC & TDN & $\mathrm{CN}$ & $\mathrm{Abs}_{254}$ & $\begin{array}{c}\mathrm{SUVA}_{2} \\
54 \\
\end{array}$ & $\begin{array}{l}\delta^{13} \mathrm{C}^{-} \\
\mathrm{CH}_{4} \\
\end{array}$ & $\mathrm{PW}_{\mathrm{CH} 4}$ & $\mathrm{~S}_{\mathrm{CH} 4}$ & $\begin{array}{c}\log \\
\mathrm{F}_{\mathrm{CH} 4}\end{array}$ \\
\hline Community & 1.00 & & & & & & & & & & & & & \\
\hline LAI2000 & 0.00 & 1.00 & & & & & & & & & & & & \\
\hline LAI & 0.68 & 0.16 & 1.00 & & & & & & & & & & & \\
\hline EV \% & 0.87 & 0.18 & 0.77 & 1.00 & & & & & & & & & & \\
\hline WT & -0.70 & -0.03 & -0.39 & -0.81 & 1.00 & & & & & & & & & \\
\hline DOC & -0.27 & 0.18 & -0.61 & -0.30 & -0.23 & 1.00 & & & & & & & & \\
\hline TDN & -0.21 & 0.68 & -0.33 & -0.12 & -0.16 & 0.64 & 1.00 & & & & & & & \\
\hline $\mathrm{CN}$ & 0.04 & -0.74 & -0.01 & -0.04 & 0.05 & -0.19 & -0.86 & 1.00 & & & & & & \\
\hline $\mathrm{Abs}_{254}$ & -0.46 & 0.02 & -0.75 & -0.49 & 0.05 & 0.79 & 0.40 & -0.02 & 1.00 & & & & & \\
\hline $\mathrm{SUVA}_{254}$ & 0.26 & -0.18 & 0.59 & 0.28 & 0.25 & -0.99 & -0.66 & 0.21 & -0.71 & 1.00 & & & & \\
\hline$\delta^{13} \mathrm{C}^{-} \mathrm{CH}_{4}$ & -0.59 & -0.45 & -0.94 & -0.72 & 0.30 & 0.55 & 0.09 & 0.28 & 0.63 & -0.56 & 1.00 & & & \\
\hline $\mathrm{PW}_{\mathrm{CH} 4}$ & -0.38 & 0.12 & 0.30 & -0.28 & 0.63 & -0.52 & -0.24 & -0.03 & -0.56 & 0.48 & -0.28 & 1.00 & & \\
\hline $\mathrm{S}_{\mathrm{CH} 4}$ & -0.59 & 0.42 & -0.06 & -0.33 & 0.42 & 0.01 & 0.16 & -0.15 & -0.12 & -0.05 & -0.01 & 0.69 & 1.00 & \\
\hline $\log \mathrm{F}_{\mathrm{CH} 4}$ & 0.65 & 0.05 & 0.54 & 0.72 & -0.80 & 0.06 & 0.14 & -0.17 & -0.05 & -0.04 & -0.51 & -0.46 & -0.60 & 1.00 \\
\hline
\end{tabular}




\subsection{DISCUSSION}

Vegetation community characteristics are often used as a predictor for $\mathrm{CH}_{4}$ emissions in peatlands, with sedge-dominated vegetation expected to have greater emissions than shrub, herb or moss dominated plots (Ward et al. 2013). At Mer Bleue, community type or \% LAI attributed to Eriophorum (EV\%), more specifically, was an important variable associated with greater $\mathrm{CH}_{4}$ emissions, more depleted $\delta^{13} \mathrm{C}-\mathrm{CH}_{4}$ source signature, and less storage change of $\mathrm{CH}_{4}$ although perhaps surprisingly, there was no direct relationship between $E V \%$ and pore water characteristics. WT correlated well with community type and the $E V \%$ (Figure 4-21). WT at Mer Bleue is a good indicator of the potential magnitude of $\mathrm{CH}_{4}$ emissions (Moore et al. 2011, Brown et al. 2014, Lai et al. 2014a). WT is also a good indicator of the vegetation community composition, where sedge cover (Eriophorum vaginatum) increased as the average WT depth approached the surface, and dwarf shrubs (Chamaedaphne calyculata) dominated in drier hummock positions (Bubier et al. 2006).

The $\delta^{13} \mathrm{C}-\mathrm{CH}_{4}$ source signatures for all nine chambers ranged from -81 to $-71 \%$, all well within the -110 to $-60 \%$ range, suggesting the dominance of the $\mathrm{CO}_{2}$ reduction pathway for $\mathrm{CH}_{4}$ production at Mer Bleue (Whiticar et al. 1986). Although the vegetation community composition did not have a significant effect on the source signature when accounting for the random effects of the repeated measurements on a chamber (Figure 4-18), a simple negative correlation with the $E V \%$ suggested the influence of transport effects on source signature, as increased sedge cover allows for increased plant-mediated $\mathrm{CH}_{4}$ transport. Plant-mediated transport processes, as well as diffusion processes, 
preferentially remove the lighter ${ }^{12} \mathrm{C}-\mathrm{CH}_{4}$ (Chanton 2005). However, the distance $\mathrm{CH}_{4}$ diffuses through the oxidation zone will also impact the $\delta^{13} \mathrm{C}-\mathrm{CH}_{4}$ value due to the substantial fractionation (5-30\%) of $\mathrm{C}$ by methanotrophs (i.e. microbes preferentially consume ${ }^{12} \mathrm{C}_{-} \mathrm{CH}_{4}$ ) (Whiticar 1999). In a study investigating $\mathrm{C}$ fractionation by methanotrophs, Coleman et al. (1981) found evidence for a microbial preference for the consumption of lighter ${ }^{12} \mathrm{C}-\mathrm{CH}_{4}$, leaving residual $\mathrm{CH}_{4}$ enriched with heavier ${ }^{13} \mathrm{C}$ after $\mathrm{CH}_{4}$ oxidation. Thus, Figure 4-18 suggests that the presence of Eriophorum allows the direct transport of lighter, more depleted $\mathrm{CH}_{4}$ to the atmosphere by bypassing the $\mathrm{CH}_{4}$ consumption zone and associated fractionation by methanotrophs.

Optimal $\mathrm{CH}_{4}$ production conditions are likely related to input and output dynamics of potential substrates (Kalbitz et al. 2000, Preston et al. 2011), as organic C substrate and a source of $\mathrm{N}$ are necessary for methanogenic activity. The instantaneous DOC and TDN concentrations obtained from pore water are a function of production processes involving multiple sources (e.g. litter and humus, root exudates, microbial biomass), consumption through microbial activity, and transport dynamics (e.g. flushing, adsorption) (Kalbitz et al. 2000, Preston et al. 2011). While TDN comprises ammonium $\left(\mathrm{NH}_{4}^{+}\right)$, nitrate $\left(\mathrm{NO}_{3}{ }^{-}\right)$and dissolved organic nitrogen (DON), a previous study showed that the majority of TDN in Mer Bleue pore water is in the organic DON form (Rattle 2006). As such, there is an interaction between $\mathrm{C}$ and $\mathrm{N}$ cycling, and patterns in TDN are related to DOC dynamics (Rattle 2006). The current study demonstrated increasing pore water concentrations of DOC and TDN over the season (Figure 4-13). During the spring, snowmelt at Mer Bleue flushes the peat with small concentrations of DOC and TDN. As peat temperature increases throughout the growing season, decomposition processes 
accelerate and both DOC and TDN are released into pore water (Moore \& Dalva 1993, Kalbitz et al. 2000, Moore \& Dalva 2000, Lai 2009). This likely contributes to the increasing seasonal pattern in DOC and TDN observed at all depths over 2014 at Mer Bleue.

The $\mathrm{C} / \mathrm{N}$ ratio was assumed to be equal to the $\mathrm{DOC} / \mathrm{TDN}$ ratio since TDN in pore water is dominated by DON at Mer Bleue (Rattle 2006). The pore water C/N ratio demonstrated limited temporal variation, which reflects the seasonal increases in both DOC and TDN (Figure 4-13). The pore water $\mathrm{C} / \mathrm{N}$ ratio decreased with depth, similar to patterns in peat $\mathrm{C} / \mathrm{N}$ ratio found in previous studies (Hornibrook et al. 2000b, Malmer \& Wallén 2004, Rydin \& Jeglum 2013, Wang et al. 2015). This can be attributed to a loss of $\mathrm{C}$ (i.e. consumption of carbohydrates) and fixation of $\mathrm{N}$ by microorganisms with depth (Hornibrook et al. 2000b, Rydin \& Jeglum 2013). The peak TDN, and corresponding trough in $\mathrm{C} / \mathrm{N}$ ratio, that occurred in June may have been a function of spring thawing and microbial turnover (Moore \& Dalva 2000).

The quality of the DOC substrate was assessed using $\mathrm{SUVA}_{254}$ measurements, which have a positive linear relation with DOC aromaticity (Weishaar et al. 2003, Olefeldt \& Roulet 2012). Thus, greater SUVA 254 for pore water DOC indicates greater aromaticity of the DOC molecule (Weishaar et al. 2003). Measured SUVA254 values fell within the commonly reported range of $0.5-6.0 \mathrm{~L} \mathrm{~m}^{-1} \mathrm{mg}^{-1} \mathrm{DOC}$, corresponding to a percent aromaticity of 5-45\% (Weishaar et al. 2003). The current results indicate an inverse relation between DOC and SUVA 254 measurements, with $\mathrm{SUVA}_{254}$ (and thus DOC aromaticity) decreasing as the season progressed (Figure 4-13). This suggests that at low initial DOC concentrations at the beginning of the season, DOC is more aromatic 
in nature. Since methanogens favour simple, relatively labile DOC molecules, this could limit $\mathrm{CH}_{4}$ production during this early summer period (Blodau 2001). The increasing DOC concentration and lability over the 2014 summer at Mer Bleue supports findings by Kane et al. (2014), where increased temperature $\left(1.9 \pm 0.4^{\circ} \mathrm{C}\right)$ in poor fen plots produced increased concentrations of more labile DOC in pore water.

One reason neither community type nor $E V \%$ directly related to pore water characteristics may have been due to the significant variability in pore water characteristics for Eriophorum community plots (Figure 4-14). This could be the result of the deeper rooting zone of sedges, which add labile $\mathrm{C}$ and other organic substrates to the anaerobic zone, potentially contributing to the increased variability in TDN and DOC quantity and quality.

The increasing seasonal DOC and TDN pore water concentrations, in conjunction with the presence of more labile DOC as the summer progressed, likely contributed to the spatial and temporal variability of pore water $\mathrm{CH}_{4}$ concentrations at depth. The pore water $\mathrm{CH}_{4}$ concentrations measured in this study were in range with those measured by Blodau et al. (2007) during 2003-2004, which yielded $\mathrm{CH}_{4}$ concentrations in the range of 0-600 $\mu \mathrm{mol} \mathrm{L}{ }^{-1}$. In this study, pore water $\mathrm{CH}_{4}$ concentrations peaked at $50 \mathrm{~cm}$ by late summer (Figure 4-15). Similarly Blodau et al. (2007) also found increasing concentrations over the summer months, with a peak $\mathrm{CH}_{4}$ concentration at $40-55 \mathrm{~cm}$ by September/October in 2003 but a general trend of increasing concentrations with depth in 2004 (to $60 \mathrm{~cm}$ ). This could be attributed to differences in moisture conditions where 2003 and 2004 WT reached depths 10-14 cm deeper than in 2014 and may have resulted in a deeper zone of $\mathrm{CH}_{4}$ production. Also, sampling methods differed, where Blodau et 
al. (2007) used the peeper technique and the current study used suction sampling and closed piezometer techniques. As previously detailed (Section 1.1.1), the peeper technique requires long equilibration times; from June 2003 to December 2004, Blodau et al. (2007)'s peepers were only sampled 12 times, for example. The shorter weekly interval between samples in the current study may have captured $\mathrm{CH}_{4}$ concentration depth patterns that were not apparent with monthly sampling (i.e. spatial variability at a shorter time scale). Redox potential measurements obtained during the late-summer period supported the importance of the $50 \mathrm{~cm}$ peak in the $\mathrm{CH}_{4}$ concentration profile, as they indicated strongly reducing conditions $(<-100 \mathrm{mV})$ (Zhi-Guang 1985) at around this depth for most chambers.

In general, plots with smaller fluxes tended to have greater increases in $\mathrm{CH}_{4}$ storage over the measurement period. For example, the Chamaedaphne community produced some of the largest pore water $\mathrm{CH}_{4}$ concentrations at depth in late summer (Figure 4-15). Yet, this community consistently had the lowest $\mathrm{CH}_{4}$ fluxes throughout the summer (Table 4-1, Figure 4-5). Since it is unlikely production rates were greater in Chamaedaphne plots, this suggests the influence of restrictive transport of $\mathrm{CH}_{4}$ to the atmosphere and/or greater $\mathrm{CH}_{4}$ consumption within the aerated peat at Chamaedaphne plots. As discussed earlier, there is evidence of Eriophorum providing a direct pathway to the atmosphere through aerenchymatous tissue such that more Eriophorum plants may enhance transport and limit the build-up of $\mathrm{CH}_{4}$ in the pore water, with the opposite occurring in Chamaedaphne-dominated plots where diffusion through the peat (or ebullition) are the dominant pathways. 
Although there is no direct measure of production rates in this study, production may have been lower in Chamaedaphne-dominated plots and greater in plots with more Eriophorum despite the greater pore water concentrations of $\mathrm{CH}_{4}$ in Chamaedaphne plots. Eriophorum is usually associated with enhanced $\mathrm{C}$ and substrate addition leading to increased $\mathrm{CH}_{4}$ production (Strack et al. 2008). The Eriophorum community produced a relatively restricted pore water $\mathrm{CH}_{4}$ profile in early summer, with the late-summer profile demonstrating a more clear peak in $\mathrm{CH}_{4}$ concentrations at $50 \mathrm{~cm}$ despite chamber E-M 2 having very low late-summer $\mathrm{CH}_{4}$ concentrations at $50 \mathrm{~cm}$ and drawing the community average down. This chamber was also associated with very high $10 \mathrm{~cm}$ soil temperature (Figure 4-7), moderate fluxes and redox potential values in the -100 to $0 \mathrm{mV}$ range during late summer, indicating a lack of strongly reducing conditions associated with $\mathrm{CO}_{2}$ reduction to $\mathrm{CH}_{4}$ (Figure 4-12). This implies that methanogenic activity was not optimized at the 40-50 cm production zone for E-M 2. While this redox status does not indicate the predominance of $\mathrm{O}_{2}(>400 \mathrm{mV})$, it may provide evidence that $\mathrm{CO}_{2}$ reduction processes are being suppressed by the consumption of more favourable terminal electron acceptors such as iron or sulfur (Table 2-1) (Deppe et al. 2010b, Bridgham et al. 2013). In contrast, strongly reducing conditions $(\sim-200 \mathrm{mV})$ were found at $40-50 \mathrm{~cm}$ depth for E-M 1 (Figure 4-11) where both $\mathrm{CH}_{4}$ fluxes and $50 \mathrm{~cm}$ concentrations were high mid- to late-summer. Below this depth, decomposition is likely limited by substrate supply, possibly leading to a greater proportion of terminal electron acceptors higher up the redox pair cascade (i.e. $\mathrm{SO}_{4}{ }^{2-}, \mathrm{Fe}^{3+}$ ) and redox potential measurements that are less negative. Although E-M 3 also showed evidence for strongly reducing conditions ( -200 mV) and produced large $50 \mathrm{~cm} \mathrm{CH}_{4}$ concentrations late in the season, it consistently had the lowest 
$\mathrm{CH}_{4}$ fluxes of the Eriophorum chambers throughout the summer. This Eriophorum plant was sitting atop a hummock that was $\sim 9 \mathrm{~cm}$ above the top of the collar and surrounding peat surface. This possibly exposed a greater surface area of peat to the atmosphere in the top $9 \mathrm{~cm}$ and contributed to increased $\mathrm{CH}_{4}$ consumption potential as the $\mathrm{CH}_{4}$ diffused up through the aerobic zone. C-A 1 and 3 both showed relatively large mean seasonal storage change, while C-A 2 had a value similar to other chambers in the Ledum and Eriophorum communities (Figure 4-19). As this Chamaedaphne chamber had the deepest WT of all chambers, it is likely that oxidation processes were again consuming $\mathrm{CH}_{4}$ in the aerobic peat layer, yielding small $\mathrm{CH}_{4}$ fluxes and a smaller than expected increase in $\mathrm{CH}_{4}$ storage over the season.

The seasonal increase in $50 \mathrm{~cm} \mathrm{CH}_{4}$ concentrations is likely tied to increasing trends in DOC and TDN, which are required for methanogen metabolism. As $50 \mathrm{~cm}$ temperatures increased as the summer progressed, decomposition rates would have been expected to increase. Previous studies have addressed the importance of peat temperature for $\mathrm{CH}_{4}$ dynamics, where $\mathrm{CH}_{4}$ production rates are positively related to peat temperature (Dunfield et al. 1993, Valentine et al.1994). $\mathrm{CH}_{4}$ oxidation processes, however, are not as sensitive to temperature (Dunfield et al. 1993). In an examination of northern fens, a peatland hydrologic model by Roulet et al. (1992) predicted that an increase in air temperature of $3^{\circ} \mathrm{C}$ and associated increase in $10 \mathrm{~cm}$ peat temperature of $0.8^{\circ} \mathrm{C}$ could produce a $\mathrm{CH}_{4}$ flux increase of $5-40 \%$. In the current study, peat temperature at $10 \mathrm{~cm}$ was not a significant control on $\mathrm{CH}_{4}$ fluxes over the 2014 sampling period (Figure 4-7). The pattern in $10 \mathrm{~cm}$ peat temperature was influenced by day-to-day variation, with patterns very similar to daily air temperature (Figure 4-3). Moore et al. (2011) found 40 
cm peat temperature at Mer Bleue was significantly correlated with $\mathrm{CH}_{4}$ flux, with WT representing a control on seasonal differences in $\mathrm{CH}_{4}$ flux. The present study found 50 cm peat temperature to relate best with $\mathrm{CH}_{4}$ flux (Figure 4-8), presumably because this depth is where $\mathrm{CH}_{4}$ production is greatest (Blodau et al. 2007) and it is this mechanism that is likely most important in determining $\mathrm{CH}_{4}$ emission rates. Although, warmer temperatures may also enhance $\mathrm{CH}_{4}$ transport processes and reduce storage in pore water.

The statistically significant interaction effect of vegetation community and $50 \mathrm{~cm}$ peat temperature on $\mathrm{CH}_{4}$ flux suggested that vegetation communities' $\mathrm{CH}_{4}$ dynamics differed in their response to increased peat temperature. Previous studies have suggested that increased peat temperature could enhance ebullition $\mathrm{CH}_{4}$ flux by increasing bubble volume (Fechner-Levy \& Hemond 1996). It is possible that this increased ebullition flux response disproportionately impacts low-lying plots with WT close to the surface, as bubbles would have a thinner aerobic layer to traverse and would thereby have reduced potential for consumption through $\mathrm{CH}_{4}$ oxidation. Increased peat temperature has also been suggested to enhance plant $\mathrm{CH}_{4}$ transport through increased aerenchyma ventilation (Große 1996). This further underlines the influence of Eriophorum on $\mathrm{CH}_{4}$ transport and emission rates. 


\subsection{CONCLUSION}

Upon examination of a variety of potential mechanisms associated with $\mathrm{CH}_{4}$ dynamics and inferred differences in $\mathrm{CH}_{4}$ production, storage and transport processes for dominant vegetative communities during a wet summer at Mer Bleue, the following conclusions can be drawn in reference to thesis hypotheses:

1. During the growing season, both spatial and temporal variability in $\mathrm{CH}_{4}$ emissions were high but temporal variations were greatest in the plots dominated by Eriophorum plants likely due to the combined effects of temporal variability in substrate production for methanogens and the influence of aerenchymatous tissues on $\mathrm{CH}_{4}$ transport to the atmosphere.

2. Pore water biogeochemistry suggested increasing substrate availability and $\mathrm{CH}_{4}$ production rates as peat temperature and plant growth increased throughout the growing season. Conditions for $\mathrm{CH}_{4}$ production via $\mathrm{CO}_{2}$ reduction were optimized near the $50 \mathrm{~cm}$ depth, as this depth is characterized by strongly reducing conditions and is close enough to the long-term average WT at Mer Bleue for sufficient organic C substrate supply.

3. The nonlinear relationship between mean $50 \mathrm{~cm} \mathrm{CH}_{4}$ storage change and mean $\mathrm{CH}_{4}$ flux provided support for the hypothesis that plots with smaller storage increase are associated with larger $\mathrm{CH}_{4}$ emissions. However, the lack of a significant linear relationship highlights the complexity of $\mathrm{CH}_{4}$ dynamics in peatlands, and suggests a varying influence of $\mathrm{CH}_{4}$ transport and consumption processes among chambers and communities at Mer Bleue. 
Considering the uncertainty surrounding the global $\mathrm{CH}_{4}$ budget, and the significance of $\mathrm{CH}_{4}$ emissions from northern peatland ecosystems in particular, this study contributes a site-specific examination of $\mathrm{CH}_{4}$ dynamics at the plant community scale for a temperate ombrotrophic bog that confirms the importance of plant community characteristics on $\mathrm{CH}_{4}$ emissions through factors influencing production, storage and transport. Future studies could employ isotopic analyses of pore water samples from key depths to track the movement and transformations of $\mathrm{CH}_{4}$ through the peat profile over the growing season, and enhance understanding of the relative importance of $\mathrm{CH}_{4}$ production, consumption, and transport processes at Mer Bleue. Depth profiles could also be sampled at a higher temporal and spatial resolution in conjunction with full-season redox potential measurements to confirm the presence/importance, and spatial and seasonal variability of a critical zone below the water table for $\mathrm{CH}_{4}$ production through methanogenic activity. If $\mathrm{CH}_{4}$ production processes can be primarily related to a particular depth/zone in the peat profile regardless of the peatland, this would simplify modeling efforts to improve our understanding of the role peatlands play in the global $\mathrm{CH}_{4}$ budget. Similarly, there is a need to focus not only on the influence of warmer peat on $\mathrm{CH}_{4}$ production potential, but also on the response of $\mathrm{CH}_{4}$ transport pathways to warmer peat in the context of global climate change. 


\subsection{APPENDICES}

\section{Appendix A Autochamber photographs}

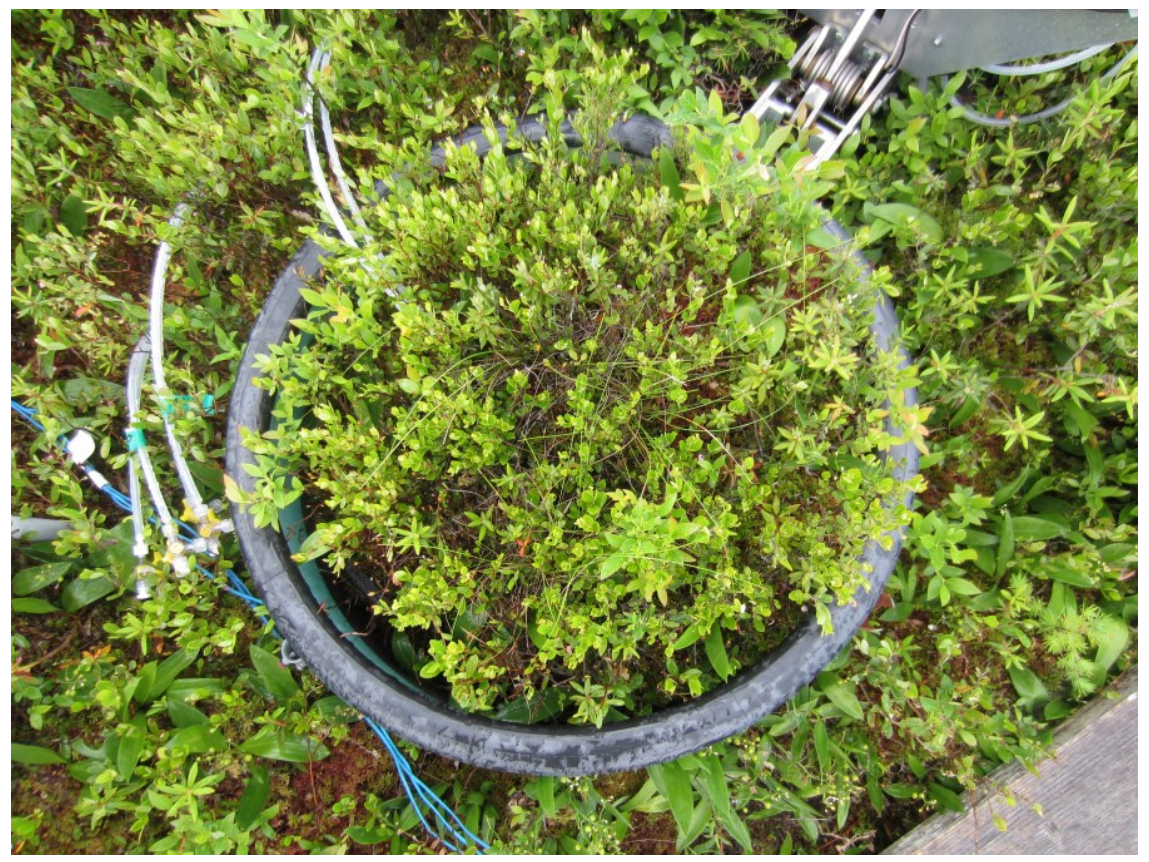

Chamaedaphne-dominated autochamber (C-A 1) on June 18, 2014.

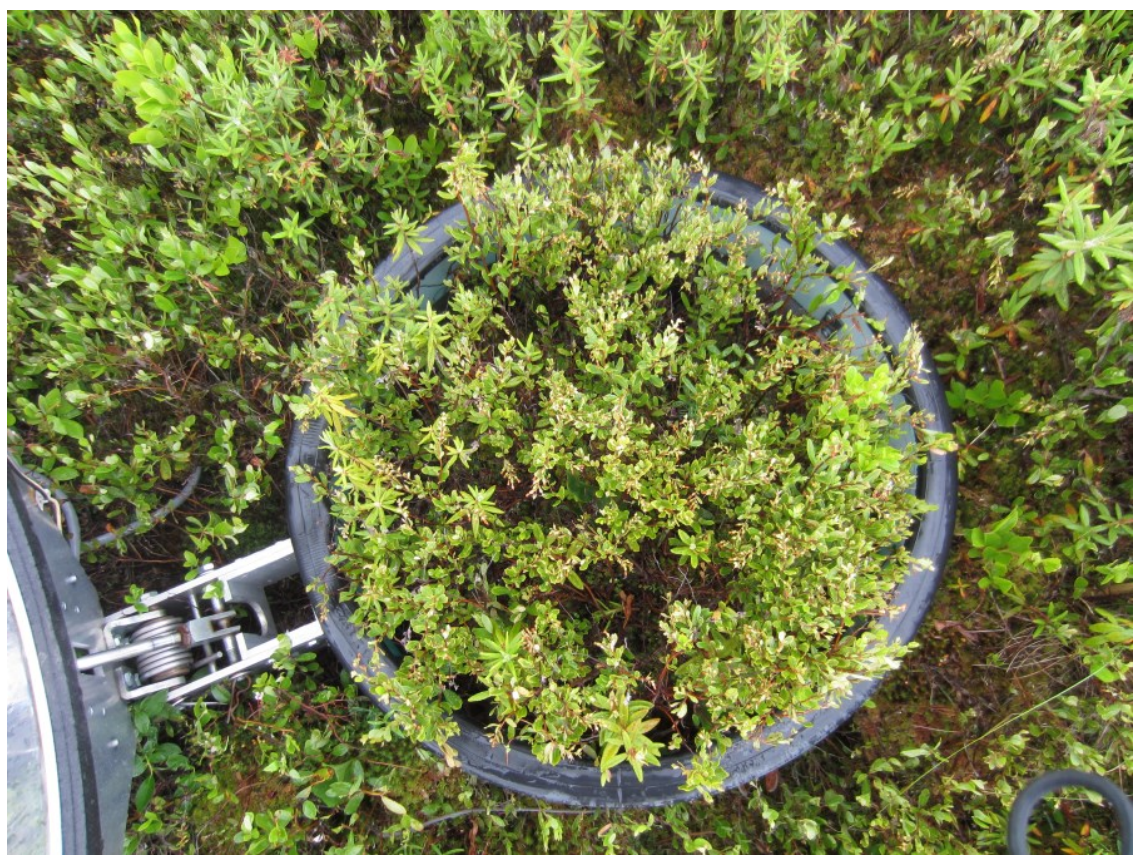

Chamaedaphne-dominated autochamber (C-A 2) on June 18, 2014. 


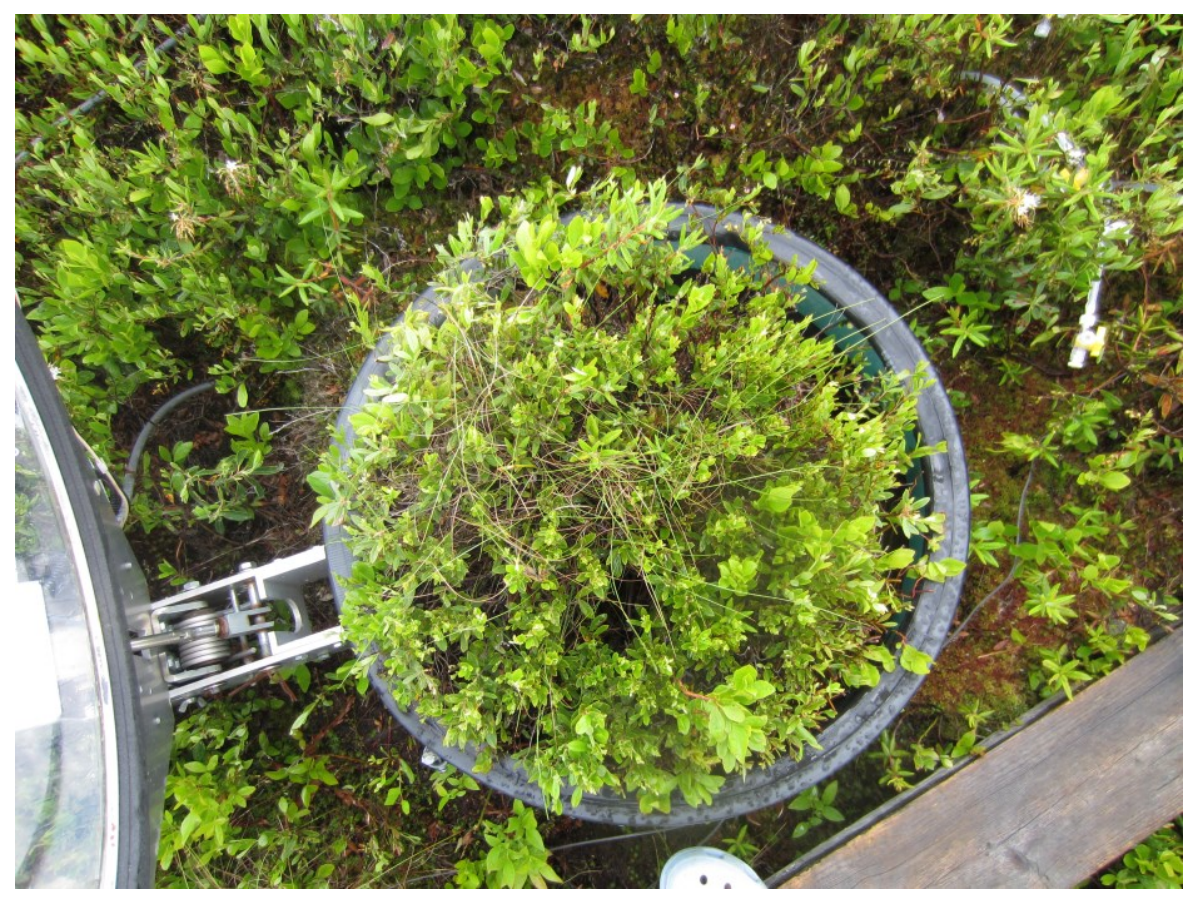

Chamaedaphne-dominated autochamber (C-A 3) on June 18, 2014.

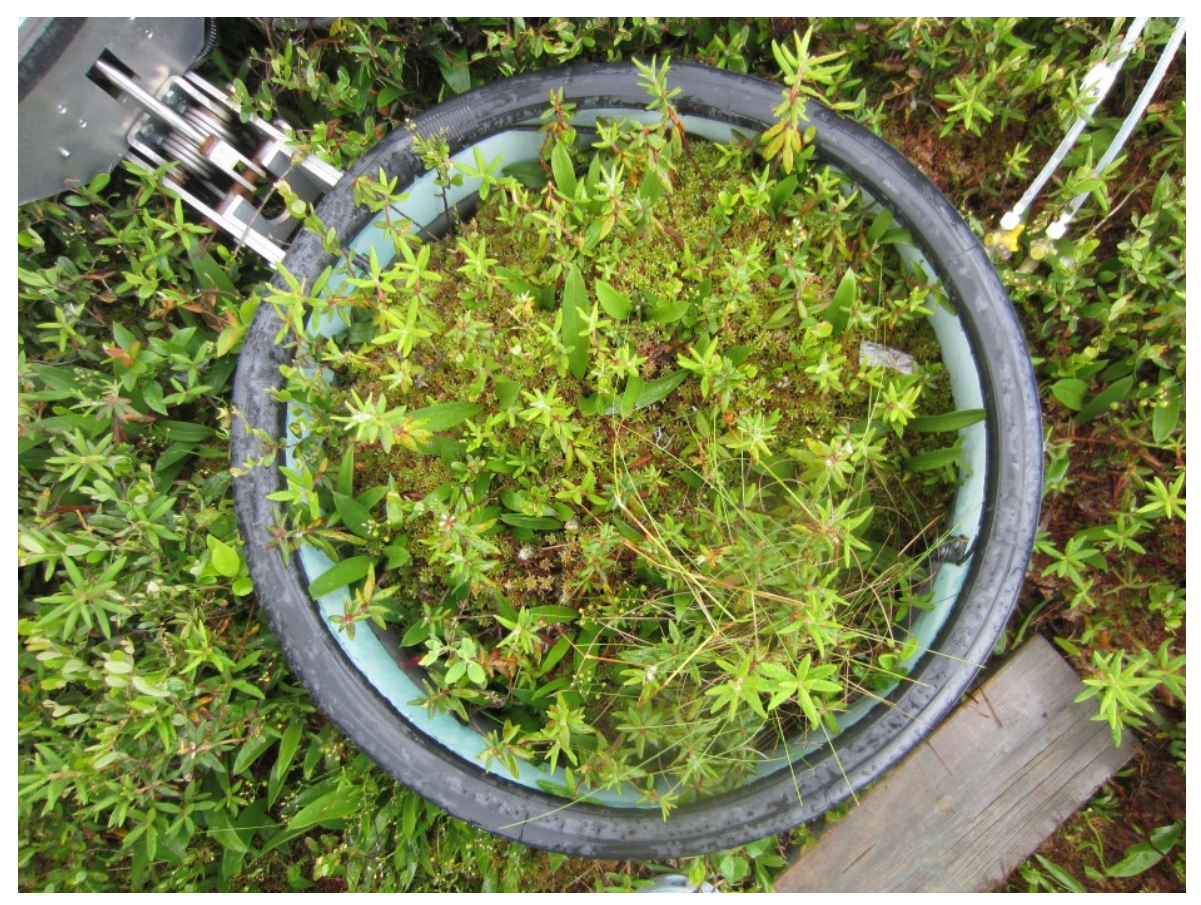

Ledum-dominated autochamber (L-A 1) on June 18, 2014. 


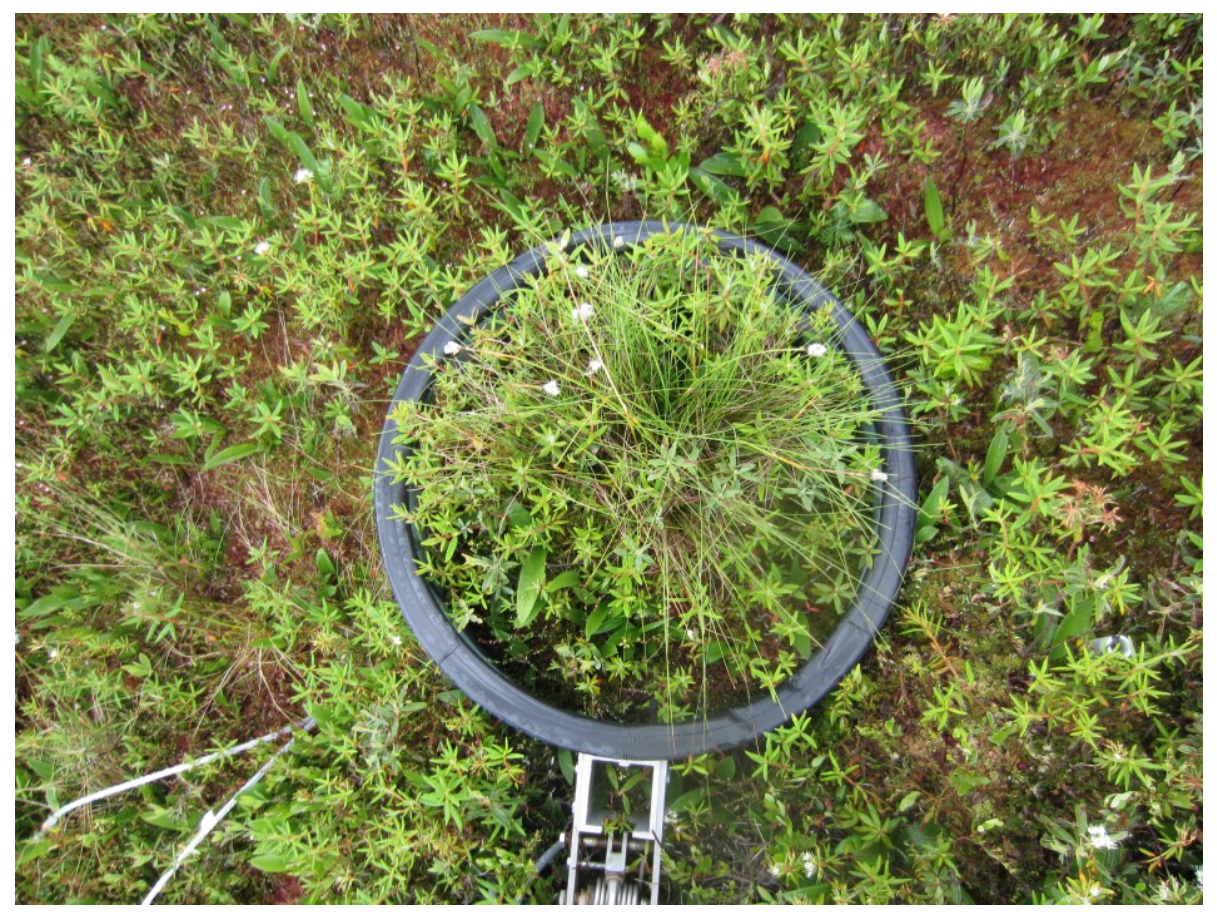

Ledum-dominated autochamber (L-A 2) on June 18, 2014.

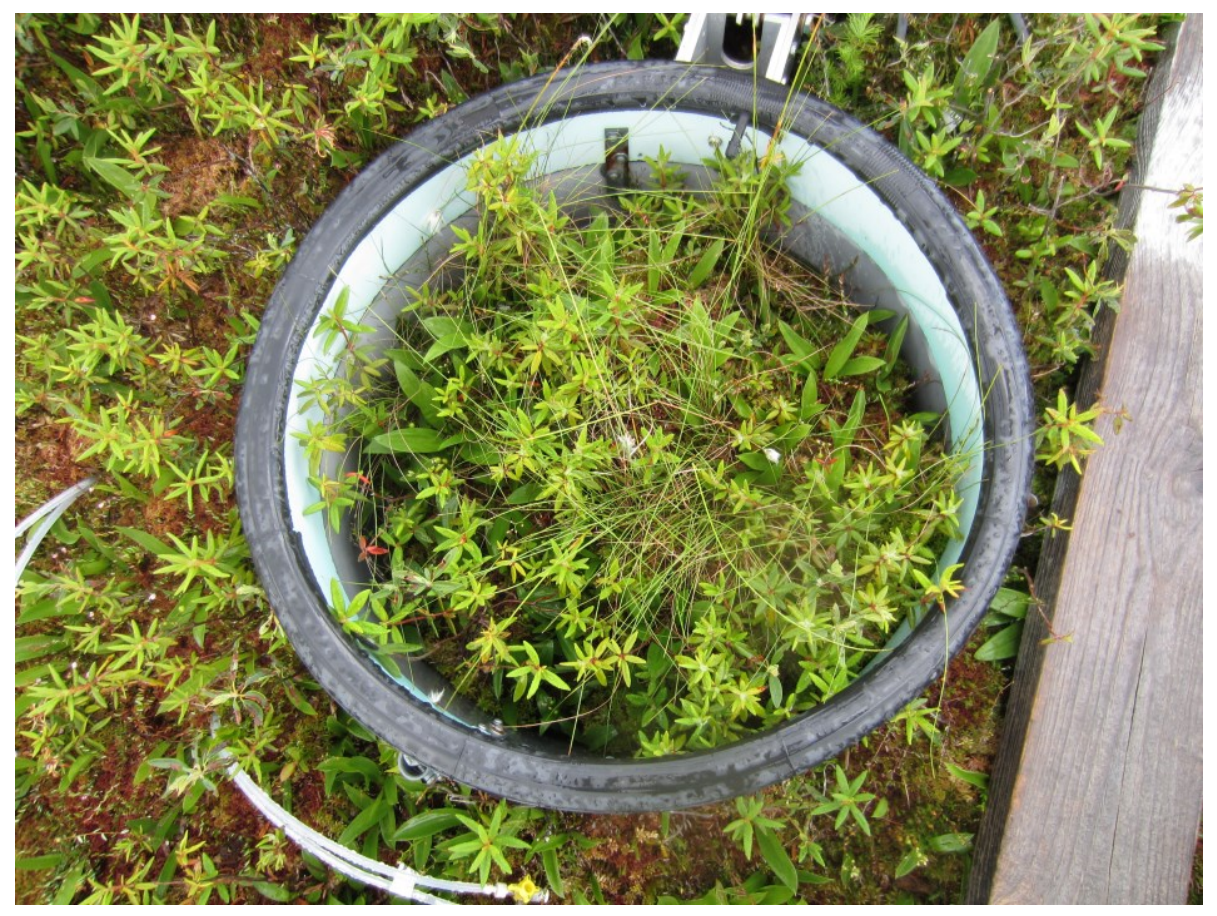

Ledum-dominated autochamber (L-A 3) on June 18, 2014. 


\section{Appendix B Calculating concentrations of pore water constituents}

\section{B.1 Units, conversions and constants}

Relevant base and supplementary SI units (Brock \& Richardson 2001).

\begin{tabular}{l|cc}
\hline \multicolumn{1}{c|}{ Physical Quantity } & Unit Name & Symbol \\
\hline Length & meter & $\mathrm{m}$ \\
Mass & kilogram & $\mathrm{kg}$ \\
Time & second & $\mathrm{s}$ \\
Thermodynamic temperature & kelvin & $\mathrm{K}$ \\
Amount of substance & mole & $\mathrm{mol}$ \\
Plane angle & radian & $\mathrm{rad}$ \\
\hline
\end{tabular}

Relevant derived units (Brock \& Richardson 2001).

\begin{tabular}{l|lccc}
\hline \multicolumn{1}{c|}{ Derived Quantity } & \multicolumn{1}{|c}{ Unit Name } & Symbol & SI Base Unit & Derived Unit \\
\hline Pressure, stress & pascal & $\mathrm{Pa}$ & $\mathrm{kg} \mathrm{m}^{-1} \mathrm{~s}^{-2}$ & $\mathrm{~N} \mathrm{~m}^{-2}$ \\
Energy, work, heat & joule & $\mathrm{J}$ & $\mathrm{kg} \mathrm{m}^{2} \mathrm{~s}^{-2}$ & $\mathrm{~N} \mathrm{~m}$ \\
Force & newton & $\mathrm{N}$ & $\mathrm{kg} \mathrm{m} \mathrm{s}^{-2}$ & \\
Power & watt & $\mathrm{W}$ & $\mathrm{kg} \mathrm{m}^{2} \mathrm{~s}^{-3}$ & $\mathrm{~J} \mathrm{~s}^{-1}$ \\
Area & square meter & $\mathrm{A}$ & $\mathrm{m}^{2}$ & \\
Volume & cubic meter & $\mathrm{V}$ & $\mathrm{m}^{3}$ & \\
\hline
\end{tabular}

Relevant units in continuous use with SI system of units (Brock \& Richardson 2001).

\begin{tabular}{l|cc}
\hline \multicolumn{1}{c|}{ Unit Name } & Symbol & $=$ \\
\hline Minute & $\min$ & $60 \mathrm{~s}$ \\
Hour & $\mathrm{h}$ & $3600 \mathrm{~s}$ \\
Day & $\mathrm{d}$ & $86400 \mathrm{~s}$ \\
Degree & $\circ$ & $(\pi / 180) \mathrm{rad}$ \\
Minute &, & $(1 / 60)^{\circ}$ \\
Second & $\prime$ & $(1 / 60)^{\prime}$ \\
Liter & $\mathrm{L}$ & $10^{-3} \mathrm{~m}^{3}$ \\
\hline
\end{tabular}

Relevant universal constants.

\begin{tabular}{l|ccc}
\hline \multicolumn{1}{c|}{ Universal Constant } & Symbol & Value & Reference \\
\hline Air density $\left(0^{\circ} \mathrm{C}, 100 \mathrm{kPa}\right)$ & $\rho_{\mathrm{a}}$ & $1.275 \mathrm{~kg} \mathrm{~m}^{-3}$ & Brock \& Richardson 2001 \\
Water density $\left(0^{\circ} \mathrm{C}\right.$, liquid) & $\rho_{\mathrm{w}}$ & $1000 \mathrm{~kg} \mathrm{~m}^{-3}$ & Brock \& Richardson 2001 \\
Ideal gas constant & $R^{*}$ & $8.3144261 \mathrm{~J} \mathrm{~mol}^{-1} \mathrm{~K}^{-1}$ & Brock \& Richardson 2001 \\
Standard atmospheric pressure & & $101.33 \mathrm{kPa}$ & Oke 1987 \\
\hline
\end{tabular}


Pressure unit conversion table.

\begin{tabular}{l|llllll}
\hline & mbar & bar & $\begin{array}{l}\text { Torr }(\mathrm{mm} \\
\text { Hg) }\end{array}$ & Pa & $k P a$ & atm \\
\hline $\begin{array}{l}1 \mathrm{mbar}= \\
1 \mathrm{bar}=\end{array}$ & 1 & $10^{3}$ & 1 & & & \\
$1 \mathrm{Torr}=$ & 1.333 & $1.333 \times 10^{-3}$ & 1 & & & \\
$1 \mathrm{~Pa}=$ & $10^{-2}$ & $10^{-5}$ & $7.5006 \times 10^{-3}$ & 1 & & \\
$1 \mathrm{kPa}=$ & $10^{1}$ & $10^{-2}$ & 7.5006 & $10^{3}$ & 1 & \\
$1 \mathrm{~atm}=$ & $1.01325 \times 10^{3}$ & 1.01325 & $7.60 \times 10^{2}$ & $1.01325 \times 10^{5}$ & $1.01325 \times 10^{2}$ & 1 \\
\hline
\end{tabular}

Other common conversions

\begin{tabular}{|c|c|c|}
\hline Unit & Gas & Solution \\
\hline $\begin{array}{l}\text { Part per million (ppm) } \\
\text { Part per billion ( } \mathrm{ppb})\end{array}$ & $\begin{array}{l}\mu \mathrm{mol} \mathrm{mol}{ }^{-1} \\
\mathrm{nmol} \mathrm{mol}^{-1}\end{array}$ & $\begin{array}{l}\mathrm{mg} / \mathrm{L} \\
\mu \mathrm{g} / \mathrm{L}\end{array}$ \\
\hline
\end{tabular}

Constants for the calculation of $\mathrm{CO}_{2}$ solubility $\left(\mathrm{mol} \mathrm{L}^{-1} \mathrm{~atm}^{-1}\right)$ from moist air at a total pressure of $1 \mathrm{~atm}$ (Weiss \& Price 1980).

\begin{tabular}{l|c}
\hline Constants & Value $\left(\right.$ mol L $\left.^{-1} \mathrm{~atm}^{-1}\right)$ \\
\hline $\mathrm{A}_{1}$ & -160.7333 \\
$\mathrm{~A}_{2}$ & 215.4152 \\
$\mathrm{~A}_{3}$ & 89.8920 \\
$\mathrm{~A}_{4}$ & -1.47759 \\
$\mathrm{~B}_{1}$ & 0.029941 \\
$\mathrm{~B}_{2}$ & -0.027455 \\
$\mathrm{~B}_{3}$ & 0.0053407 \\
\hline
\end{tabular}

Constants for the calculation of temperature $\left({ }^{\circ} \mathrm{K}\right)$ and salinity (\%o) dependent $\mathrm{CH}_{4}$ Bunsen solubility coefficient ( $\mathrm{L} \mathrm{L}^{-1} \mathrm{~atm}^{-1}$ ) (Wanninkhof 1992).

\begin{tabular}{l|c}
\hline Constants & Value $\left(\mathrm{L} \mathrm{L}^{-1} \mathrm{~atm}^{-1}\right)$ \\
\hline $\mathrm{A}_{1}$ & -68.8862 \\
$\mathrm{~A}_{2}$ & 101.4956 \\
$\mathrm{~A}_{3}$ & 28.7314 \\
$\mathrm{~B}_{1}$ & -0.076146 \\
$\mathrm{~B}_{2}$ & 0.043970 \\
$\mathrm{~B}_{3}$ & -0.0068672 \\
\hline
\end{tabular}




\section{B.2 Calculating $\mathrm{CO}_{2}$ concentration in pore water}

\section{B.2.1 $\mathrm{CO}_{2}$ solubility}

As defined by Weiss \& Price (1980), the solubility of $\mathrm{CO}_{2}$ in water $\left(F\right.$, mol L ${ }^{-1}$ $\mathrm{atm}^{-1}$ ) as a function of temperature and salinity, including all nonideality effects, is calculated as:

$$
\begin{aligned}
\ln F= & A_{1}+A_{2}(100 / T)+A_{3} \ln (T / 100)+A_{4}(T / 100)^{2} \\
& +S\left[B_{1}+B_{2}(T / 100)+B_{3}(T / 100)^{2}\right]
\end{aligned}
$$

where $A$ and $B$ values are constants $\left(\mathrm{mol} \mathrm{L}^{-1} \mathrm{~atm}^{-1}\right)$ defined in Section A.1, $T$ is absolute temperature (K) and $S$ is salinity in parts per thousand (\%o).

\section{B.2.2 $\mathrm{CO}_{2}$ in headspace}

The amount of $\mathrm{CO}_{2}$ in the headspace $\left(\mathrm{CO}_{2_{h}}, \mu \mathrm{mol}\right)$ after equilibration is calculated as:

$$
\left[\mathrm{CO}_{2}\right]_{R E S}=\left[\mathrm{CO}_{2}\right]_{G C}-\left[\mathrm{CO}_{2}\right]_{A M B}
$$

$$
C O_{2_{h}}=\left(\left[C O_{2}\right]_{R E S} \frac{P V_{h}}{R^{*} T}\right) \frac{1 m^{3}}{1000 L}
$$

where $\left[\mathrm{CO}_{2}\right]_{G C}$ is the headspace concentration of $\mathrm{CO}_{2}\left(\mu \mathrm{mol} \mathrm{CO}_{2} \mathrm{~mol}^{-1}\right)$, as measured on the gas chromatograph, $\left[\mathrm{CO}_{2}\right]_{A M B}$ is the ambient concentration of $\mathrm{CO}_{2}\left(\mu \mathrm{mol} \mathrm{CO} \mathrm{Col}^{-1}\right)$ at the time of sampling, $\left[\mathrm{CO}_{2}\right]_{R E S}$ is the residual concentration of $\mathrm{CO}_{2}$ in the headspace ( $\mu \mathrm{mol} \mathrm{CO} \mathrm{Col}^{-1}$ ) after subtracting the ambient influence, $P$ is the pressure at 
equilibration $(\mathrm{Pa}), V_{h}$ is the headspace volume after equilibration $(\mathrm{L}), R^{*}$ is the ideal gas constant $8.3144261\left(\mathrm{~J} \mathrm{~mol}^{-1} \mathrm{~K}^{-1}\right)$ as given in Section A.1, and $T$ is the absolute air temperature at equilibration $(\mathrm{K})$.

\section{B.2.3 $\mathrm{CO}_{2}$ in water}

The amount of $\mathrm{CO}_{2}$ in the water $\left(\mathrm{CO}_{2_{w}}, \mu \mathrm{mol}\right)$ after equilibration is calculated as:

$$
\mathrm{CO}_{2_{w}}=\mathrm{F} \times\left[\mathrm{CO}_{2}\right]_{R E S} \times \mathrm{P} \times V_{w}
$$

where $F$ is the $\mathrm{CO}_{2}$ solubility $\left(\mathrm{mol} \mathrm{L}^{-1}\right.$ atm $^{-1}$, Equation 1 and 2), $\left[\mathrm{CO}_{2}\right]_{R E S}$ is the residual concentration of $\mathrm{CO}_{2}$ in the headspace $\left(\mu \mathrm{mol} \mathrm{CO}_{2}\right.$ mol ${ }^{-1}$ ) as per Equation $3, P$ is the pressure at equilibration (atm), and $V_{w}$ is the water volume after equilibration (L).

\section{B.2.4 Total $\mathrm{CO}_{2}$ concentration in pore water}

The total concentration of $\mathrm{CO}_{2}$ in the pore water $\left(\left[\mathrm{CO}_{2}\right]_{P W}, \mu \mathrm{mol} \mathrm{CO}_{2} \mathrm{~L}^{-1}\right)$ can thus be calculated as:

$$
\left[\mathrm{CO}_{2}\right]_{P W}=\frac{C O_{2_{h}}+C O_{2_{w}}}{V_{w}}
$$

where $\mathrm{CO}_{2_{h}}$ and $\mathrm{CO}_{2_{w}}$ are the amount of $\mathrm{CO}_{2}$ in the headspace and water respectively after equilibration ( $\mu \mathrm{mol} \mathrm{CO}_{2}$ ), and $V_{w}$ is the water volume after equilibration (L).

\section{B.2.5 Sample $\mathrm{CO}_{2}$ pore water concentration calculations}

The above procedure was applied for sample input variables, and the calculated concentration values of $\mathrm{CO}_{2}$ in pore water are provided in the table below. 
Sample calculations for determining the concentration of $\mathrm{CO}_{2}$ in pore water according to the procedure detailed in Sections A.2.1 through A.2.4.

\begin{tabular}{|c|c|c|c|c|}
\hline Variable & Units & Sample \#1 & Sample \#2 & Sample \#3 \\
\hline$T$ & $\mathrm{~K}$ & 283.15 & 293.15 & 303.15 \\
\hline$S$ & $\%$ & 0 & 0 & 0 \\
\hline$F$ & $\mathrm{~mol} \mathrm{~L}^{-1} \mathrm{~atm}^{-1}$ & $5.28 \times 10^{-2}$ & $3.81 \times 10^{-2}$ & $2.85 \times 10^{-2}$ \\
\hline$\left[\mathrm{CO}_{2}\right]_{G C}$ & $\mu \mathrm{mol} \mathrm{CO} \mathrm{mol}^{-1}$ & $8.15 \times 10^{2}$ & $1.01 \times 10^{4}$ & $3.13 \times 10^{2}$ \\
\hline$\left[\mathrm{CO}_{2}\right]_{A M B}$ & $\mu \mathrm{mol} \mathrm{CO} \mathrm{mol}^{-1}$ & $4.02 \times 10^{2}$ & $4.02 \times 10^{2}$ & $4.02 \times 10^{2}$ \\
\hline$\left[\mathrm{CO}_{2}\right]_{\text {RES }}$ & $\mu \mathrm{mol} \mathrm{CO} 2 \mathrm{~mol}^{-1}$ & $4.13 \times 10^{2}$ & $9.65 \times 10^{3}$ & $3.09 \times 10^{4}$ \\
\hline$P$ & $\mathrm{~Pa}$ & $1.0076 \times 10^{5}$ & $1.0076 \times 10^{5}$ & $1.0076 \times 10^{5}$ \\
\hline$P$ & atm & $9.94423 \times 10^{-1}$ & $9.94423 \times 10^{-1}$ & $9.94423 \times 10^{-1}$ \\
\hline$V_{h}$ & $\mathrm{~L}$ & $3.0 \times 10^{-2}$ & $3.0 \times 10^{-2}$ & $3.0 \times 10^{-2}$ \\
\hline$V_{w}$ & $\mathrm{~L}$ & $3.0 \times 10^{-2}$ & $3.0 \times 10^{-2}$ & $3.0 \times 10^{-2}$ \\
\hline $\mathrm{CO}_{2 h}$ & $\mu \mathrm{mol} \mathrm{CO} 2$ & $5.31 \times 10^{-1}$ & $1.20 \times 10^{1}$ & $3.70 \times 10^{1}$ \\
\hline $\mathrm{CO}_{2 w}$ & $\mu \mathrm{mol} \mathrm{CO}$ & $6.51 \times 10^{-1}$ & $1.10 \times 10^{1}$ & $2.62 \times 10^{1}$ \\
\hline$\left[\mathrm{CO}_{2}\right]_{P W}$ & $\mu \mathrm{mol} \mathrm{CO} \mathrm{CO}^{-1}$ & $3.94 \times 10^{1}$ & $7.66 \times 10^{2}$ & $2.11 \times 10^{3}$ \\
\hline
\end{tabular}

\section{B.3 Calculating $\mathrm{CH}_{4}$ concentration in pore water}

\section{B.3.1 $\mathrm{CH}_{4}$ solubility}

The Bunsen solubility coefficient of $\mathrm{CH}_{4}\left(\beta, \mathrm{molL}^{-1} \mathrm{~atm}^{-1}\right)$ can be calculated as a function of temperature and salinity (Wanninkhof 1992), where:

$$
\begin{gathered}
\ln \beta=A_{1}+A_{2}(100 / T)+A_{3} \ln (T / 100)+S \boxminus B_{1}+B_{2}(T / 100)+B_{3}(T / 100)^{2} \sqsubseteq \\
\beta=e^{\ln \beta} \frac{101325}{R^{*}(298.15)} \square 0.001
\end{gathered}
$$

where $A$ and $B$ values are constants $\left(\mathrm{L} \mathrm{L}^{-1} \mathrm{~atm}^{-1}\right)$ defined in Section A.1, $T$ is absolute temperature $(\mathrm{K})$ and $S$ is salinity in parts per thousand (\%o). Equation 8 converts this solubility value from $\mathrm{L} \mathrm{CH}_{4} \mathrm{~L}^{-1}$ water atm ${ }^{-1}$ to units of mol L-1 atm ${ }^{-1}$. 


\section{B.3.2 $\mathrm{CH}_{4}$ in headspace}

The amount of $\mathrm{CH}_{4}$ in the headspace $\left(\mathrm{CH}_{4_{h}}, \mu \mathrm{mol}\right)$ after equilibration is calculated as:

$$
\begin{aligned}
& {\left[\mathrm{CH}_{4}\right]_{R E S}=\left[\mathrm{CH}_{4}\right]_{G C}-\left[\mathrm{CH}_{4}\right]_{A M B}} \\
& \mathrm{CH}_{4_{h}}=\left(\left[\mathrm{CH}_{4}\right]_{R E S} \frac{P V_{h}}{R^{*} T}\right) \frac{1 m^{3}}{1000 L}
\end{aligned}
$$

where $\left[\mathrm{CH}_{4}\right]_{G C}$ is the headspace concentration of $\mathrm{CH}_{4}\left(\mu \mathrm{mol} \mathrm{CH}_{4} \mathrm{~mol}^{-1}\right)$, as measured on the gas chromatograph, $\left[\mathrm{CH}_{4}\right]_{A}$ is the ambient concentration of $\mathrm{CH}_{4}\left(\mu \mathrm{mol} \mathrm{CH}_{4} \mathrm{~mol}^{-1}\right)$ at the time of sampling, $\left[\mathrm{CH}_{4}\right]_{R E S}$ is the residual concentration of $\mathrm{CH}_{4}$ in the headspace ( $\mu \mathrm{mol} \mathrm{CH}_{4} \mathrm{~mol}^{-1}$ ) after subtracting the ambient influence, $P$ is the pressure at equilibration $(\mathrm{Pa}), V_{h}$ is the headspace volume after equilibration $(\mathrm{L}), R^{*}$ is the ideal gas constant $8.3144261\left(\mathrm{~J} \mathrm{~K}^{-1} \mathrm{~mol}^{-1}\right)$ as given in Section A.1, and $T$ is the absolute air temperature at equilibration $(\mathrm{K})$.

\section{B.3.3 $\mathrm{CH}_{4}$ in water}

The amount of $\mathrm{CH}_{4}$ in the water $\left(\mathrm{CH}_{4_{w}}, \mu \mathrm{mol}\right)$ after equilibration is calculated as:

$$
\mathrm{CH}_{4_{w}}=\beta \square\left[\mathrm{CH}_{4}\right]_{R E S} \square P \square V_{w}
$$

where $\beta$ is the Bunsen solubility coefficient of $\mathrm{CH}_{4}\left(\mathrm{~mol} \mathrm{~L}^{-1} \mathrm{~atm}^{-1}\right.$, Equation 6 and 7), $\left[\mathrm{CH}_{4}\right]_{R E S}$ is the residual concentration of $\mathrm{CH}_{4}$ in the headspace $\left(\mu \mathrm{mol} \mathrm{CH}_{4} \mathrm{~mol}^{-1}\right), P$ is the pressure at equilibration (atm), and $V_{w}$ is the water volume after equilibration (L). 


\section{B.3.4 Total $\mathrm{CH}_{4}$ concentration in pore water}

The total concentration of $\mathrm{CH}_{4}$ in the pore water $\left(\left[\mathrm{CH}_{4}\right]_{P W}, \mu \mathrm{mol} \mathrm{CH} \mathrm{CH}^{-1}\right)$ can thus be calculated as:

$$
\left[\mathrm{CH}_{4}\right]_{P W}=\frac{\mathrm{CH}_{4_{h}}+\mathrm{CH}_{4_{w}}}{V_{w}}
$$

where $\mathrm{CH}_{4_{h}}$ and $\mathrm{CH}_{4_{w}}$ are the amount of $\mathrm{CH}_{4}$ in the headspace and water respectively after equilibration ( $\left.\mu \mathrm{mol} \mathrm{CH}_{4}\right)$, and $V_{w}$ is the water volume after equilibration (L).

\section{B.3.5 Sample $\mathrm{CH}_{4}$ pore water concentration calculations}

The above procedure was applied for sample input variables, and the calculated concentration values of $\mathrm{CH}_{4}$ in pore water are provided in the table below.

Sample calculations for determining the concentration of $\mathrm{CH}_{4}$ in pore water according to the procedure detailed in sections A.3.1 through A.3.4.

\begin{tabular}{|c|c|c|c|c|}
\hline Variable & Units & Sample \#1 & Sample \#2 & Sample \#3 \\
\hline$T$ & $\mathrm{~K}$ & 283.15 & 293.15 & 303.15 \\
\hline $\bar{S}$ & $\%$ & 0 & 0 & 0 \\
\hline$\beta$ & $\mathrm{mol} \mathrm{L}^{-1} \mathrm{~atm}^{-1}$ & $1.80 \times 10^{-3}$ & $1.40 \times 10^{-3}$ & $1.20 \times 10^{-3}$ \\
\hline$\left[\mathrm{CH}_{4}\right]_{G C}$ & $\mu \mathrm{mol} \mathrm{CH} \mathrm{mol}^{-1}$ & $1.15 \times 10^{2}$ & $5.43 \times 10^{3}$ & $1.99 \times 10^{4}$ \\
\hline$\left[\mathrm{CH}_{4}\right]_{A M B}$ & $\mu \mathrm{mol} \mathrm{CH} \mathrm{mol}^{-1}$ & $1.90 \times 10^{0}$ & $1.90 \times 10^{0}$ & $1.90 \times 10^{0}$ \\
\hline$\left[\mathrm{CH}_{4}\right]_{\text {RES }}$ & $\mu \mathrm{mol} \mathrm{CH} \mathrm{mol}^{-1}$ & $1.13 \times 10^{2}$ & $5.42 \times 10^{3}$ & $1.99 \times 10^{4}$ \\
\hline$P$ & $\mathrm{~Pa}$ & $1.0076 \times 10^{5}$ & $1.0076 \times 10^{5}$ & $1.0076 \times 10^{5}$ \\
\hline$P$ & atm & $9.94423 \times 10^{-1}$ & $9.94423 \times 10^{-1}$ & $9.94423 \times 10^{-1}$ \\
\hline$V_{h}$ & $\mathrm{~L}$ & $3.0 \times 10^{-2}$ & $3.0 \times 10^{-2}$ & $3.0 \times 10^{-2}$ \\
\hline$\overline{V_{w}}$ & $\mathrm{~L}$ & $3.0 \times 10^{-2}$ & $3.0 \times 10^{-2}$ & $3.0 \times 10^{-2}$ \\
\hline $\mathrm{CH}_{4 h}$ & $\mu \mathrm{mol} \mathrm{CH} 4$ & $1.45 \times 10^{-1}$ & $6.73 \times 10^{0}$ & $2.38 \times 10^{1}$ \\
\hline $\mathrm{CH}_{4 w}$ & $\mu \mathrm{mol} \mathrm{CH}_{4}$ & $6.07 \times 10^{-3}$ & $2.26 \times 10^{-1}$ & $7.12 \times 10^{-1}$ \\
\hline$\left[\mathrm{CH}_{4}\right]_{P W}$ & $\mu \mathrm{mol} \mathrm{CH}_{4} \mathrm{~L}^{-1}$ & $5.04 \times 10^{0}$ & $2.32 \times 10^{2}$ & $8.17 \times 10^{2}$ \\
\hline
\end{tabular}




\section{Appendix C Seasonal $\mathrm{CH}_{4}$ Fluxes}

\section{C.1 Comparison of $\mathrm{CH}_{4}$ fluxes among seasons}

Comparison of mean daily $\mathrm{CH}_{4}$ flux $\left(\mathrm{mg} \mathrm{CH}_{4} \mathrm{~m}^{-2} \mathrm{~h}^{-1}\right)$, WT $(\mathrm{cm})$ and $50 \mathrm{~cm}$ peat temperature $\left(\mathrm{T}_{50 \mathrm{~cm}},{ }^{\circ} \mathrm{C}\right)$ from Chamaedaphne (C-A 1,2,3), Ledum (L-A 1,2,3) and Eriophorum (E-M 1,2,3)-dominated communities at Mer Bleue, 2014. Standard deviation is given in parentheses. Note: WP, whole period (DOY 120-155); LSp, late spring (DOY 120-154); ES, early summer (DOY 155-189); MS, mid-summer (DOY 190-221); LS, late summer (DOY 222-255) for the 2014 measurement period.

\begin{tabular}{|c|c|c|c|}
\hline \multicolumn{4}{|c|}{ Whole Period (DOY 120-255) } \\
\hline & $\mathrm{CH}_{4}$ Flux $\left(\mathrm{mg} \mathrm{m}^{-2} \mathrm{~h}^{-1}\right)$ & WT (cm) & $\mathrm{T}_{50 \mathrm{~cm}}\left({ }^{\circ} \mathrm{C}\right)$ \\
\hline Chamaedaphne & $1.03(0.65)$ & $36.4(3.2)$ & \multirow{12}{*}{$11.1(3.0)$} \\
\hline C-A 1 & $1.68(1.14)$ & $29.1(2.4)$ & \\
\hline $\mathrm{C}-\mathrm{A} 2$ & $0.75(0.55)$ & $43.8(3.1)$ & \\
\hline C-A 3 & $0.65(0.54)$ & $34.6(3.2)$ & \\
\hline Ledum & $3.81(1.98)$ & $28.5(3.2)$ & \\
\hline L-A 1 & $2.55(0.97)$ & $28.8(2.9)$ & \\
\hline L-A 2 & $4.56(2.78)$ & $31.1(2.2)$ & \\
\hline L-A 3 & $4.25(2.27)$ & $24.6(2.8)$ & \\
\hline Eriophorum & $3.27(2.42)$ & $28.4(3.1)$ & \\
\hline E-M 1 & $6.16(4.88)$ & $25.8(2.8)$ & \\
\hline E-M 2 & $2.13(1.56)$ & $30.1(2.7)$ & \\
\hline E-M 3 & $1.27(1.22)$ & $28.2(2.6)$ & \\
\hline \multicolumn{4}{|c|}{ Late Spring (DOY 120-154) } \\
\hline Chamaedaphne & $0.31(0.10)$ & $34.9(3.2)$ & \multirow{12}{*}{$6.6(1.8)$} \\
\hline C-A 1 & $0.68(0.16)$ & $27.9(2.5)$ & \\
\hline C-A 2 & $0.22(0.14)$ & $43.4(3.3)$ & \\
\hline C-A 3 & $0.01(0.03)$ & $32.9(3.4)$ & \\
\hline Ledum & $0.99(0.33)$ & $26.9(2.9)$ & \\
\hline L-A 1 & $1.12(0.38)$ & $27.3(3.3)$ & \\
\hline L-A 2 & $0.59(0.27)$ & $29.8(2.4)$ & \\
\hline L-A 3 & $1.20(0.30)$ & $23.1(2.9)$ & \\
\hline Eriophorum & $0.42(0.34)$ & $N / A$ & \\
\hline E-M 1 & $0.33(0.32)$ & $30.2(1.6)$ & \\
\hline E-M 2 & $0.68(0.46)$ & $34.0(1.5)$ & \\
\hline E-M 3 & $0.40(0.44)$ & $31.9(1.4)$ & \\
\hline
\end{tabular}




\begin{tabular}{|c|c|c|c|}
\hline \multicolumn{4}{|c|}{ Early Summer (DOY 155-189) } \\
\hline & $\mathrm{CH}_{4}$ Flux $\left(\mathrm{mg} \mathrm{m}^{-2} \mathrm{~h}^{-1}\right)$ & WT (cm) & $\mathrm{T}_{50 \mathrm{~cm}}\left({ }^{\circ} \mathrm{C}\right)$ \\
\hline Chamaedaphne & $0.88(0.38)$ & $37.8(3.4)$ & \multirow{12}{*}{$11.3(1.2)$} \\
\hline C-A 1 & $1.60(0.80)$ & $29.1(1.7)$ & \\
\hline C-A 2 & $0.62(0.21)$ & $43.7(3.5)$ & \\
\hline C-A 3 & $0.38(0.25)$ & $34.3(2.9)$ & \\
\hline Ledum & $3.41(0.90)$ & $27.9(2.5)$ & \\
\hline L-A 1 & $2.60(0.42)$ & $28.6(2.6)$ & \\
\hline L-A 2 & $4.04(1.39)$ & $31.2(2.3)$ & \\
\hline L-A 3 & $3.36(1.02)$ & $24.4(2.5)$ & \\
\hline Eriophorum & $1.58(0.72)$ & $27.8(3.6)$ & \\
\hline E-M 1 & $2.57(1.71)$ & $25.0(2.9)$ & \\
\hline E-M 2 & $1.22(0.91)$ & $29.4(2.8)$ & \\
\hline E-M 3 & $0.49(0.57)$ & $27.5(2.7)$ & \\
\hline \multicolumn{4}{|c|}{ Mid Summer (DOY 190-221) } \\
\hline Chamaedaphne & $1.44(0.50)$ & $37.4(2.6)$ & \multirow{12}{*}{$13.2(0.2)$} \\
\hline C-A 1 & $2.29(1.29)$ & $30.4(2.3)$ & \\
\hline C-A 2 & $0.99(0.53)$ & $45.1(2.6)$ & \\
\hline C-A 3 & $1.03(0.20)$ & $36.7(2.8)$ & \\
\hline Ledum & $5.33(0.23)$ & $30.5(3.2)$ & \\
\hline L-A 1 & $3.22(0.19)$ & $30.6(2.2)$ & \\
\hline L-A 2 & $6.56(0.62)$ & $32.5(1.6)$ & \\
\hline L-A 3 & $6.11(0.37)$ & $26.6(2.6)$ & \\
\hline Eriophorum & $5.27(1.83)$ & $28.8(3.4)$ & \\
\hline E-M 1 & $9.57(3.77)$ & $27.0(2.6)$ & \\
\hline E-M 2 & $2.80(1.66)$ & $31.4(2.6)$ & \\
\hline E-M 3 & $1.88(1.52)$ & $29.3(2.5)$ & \\
\hline \multicolumn{4}{|c|}{ Late Summer (DOY 222-255) } \\
\hline Chamaedaphne & $1.58(0.57)$ & $35.6(2.5)$ & \multirow{12}{*}{$13.6(0.4)$} \\
\hline C-A 1 & $2.23(1.16)$ & $28.9(2.3)$ & \\
\hline C-A 2 & $1.22(0.61)$ & $43.0(2.7)$ & \\
\hline C-A 3 & $1.27(0.32)$ & $34.7(2.5)$ & \\
\hline Ledum & $5.83(0.35)$ & $28.7(3.1)$ & \\
\hline L-A 1 & $3.35(0.55)$ & $28.6(2.4)$ & \\
\hline L-A 2 & $7.41(0.65)$ & $31.1(1.8)$ & \\
\hline L-A 3 & $6.64(0.22)$ & $24.3(2.0)$ & \\
\hline Eriophorum & $5.20(1.41)$ & $28.9(2.4)$ & \\
\hline E-M 1 & $10.04(3.32)$ & $25.1(2.4)$ & \\
\hline E-M 2 & $3.43(1.15)$ & $29.2(2.2)$ & \\
\hline E-M 3 & $2.01(0.89)$ & $27.5(2.2)$ & \\
\hline
\end{tabular}


Comparison of mean daily $\mathrm{CH}_{4}$ flux $\left(\mathrm{mg} \mathrm{CH}_{4} \mathrm{~m}^{-2} \mathrm{~h}^{-1}\right)$, WT $(\mathrm{cm})$ and $50 \mathrm{~cm}$ peat temperature $\left(\mathrm{T}_{50 \mathrm{~cm}},{ }^{\circ} \mathrm{C}\right)$ from Chamaedaphne (C-A 1,2,3), Ledum (L-A 1,2,3) and Eriophorum (E-M 1,2,3)-dominated communities at Mer Bleue, 2014. Standard deviation is given in parentheses. Note: WP, whole period (DOY 120-155); LSp, late spring (DOY 120-154); ES, early summer (DOY 155-189); MS, mid-summer (DOY 190-221); LS, late summer (DOY 222-255) for the 2014 measurement period.

\begin{tabular}{|c|c|c|c|c|c|c|}
\hline \multicolumn{2}{|c|}{ Chamaedaphne } & \multicolumn{2}{|c|}{$\underline{\text { Ledum }}$} & \multicolumn{2}{|c|}{ Eriophorum } & \multirow[b]{2}{*}{$\mathrm{T}_{50 \mathrm{~cm}}\left({ }^{\circ} \mathrm{C}\right)$} \\
\hline $\begin{array}{c}\mathrm{CH}_{4} \text { Flux (mg } \\
\left.\mathrm{CH}_{4} \mathrm{~m}^{-2} \mathrm{~h}^{-1}\right)\end{array}$ & WT $(\mathrm{cm})$ & $\begin{array}{c}\mathrm{CH}_{4} \text { Flux (mg } \\
\left.\mathrm{CH}_{4} \mathrm{~m}^{-2} \mathrm{~h}^{-1}\right)\end{array}$ & WT (cm) & $\begin{array}{c}\mathrm{CH}_{4} \text { Flux (mg } \\
\left.\mathrm{CH}_{4} \mathrm{~m}^{-2} \mathrm{~h}^{-1}\right)\end{array}$ & WT (cm) & \\
\hline \multicolumn{7}{|c|}{ Whole Period (DOY 120-255, $n=1116)$} \\
\hline $1.03^{\mathrm{b}}(0.65)$ & $36.4^{\mathrm{a}}(3.2)$ & $3.81^{\mathrm{a}}(1.98)$ & $28.5^{\mathrm{ab}}(3.2)$ & $3.26^{\mathrm{ab}}(2.42)$ & $28.0^{\mathrm{b}}(2.7)$ & $11.1(3.0)$ \\
\hline \multicolumn{7}{|c|}{ Late Spring (DOY 120-154, $n=207$ ) } \\
\hline $0.31^{\mathrm{b}}(0.09)$ & $34.9^{\mathrm{a}}(3.2)$ & $0.99^{\mathrm{a}}(0.33)$ & $26.9^{\mathrm{a}}(2.9)$ & $0.42^{\mathrm{NA}}(0.34)$ & $\mathrm{N} / \mathrm{A}$ & $6.6(1.8)$ \\
\hline \multicolumn{7}{|c|}{ Early Summer (DOY 155-189, $n=207$ ) } \\
\hline $0.88^{\mathrm{b}}(0.38)$ & $37.8^{\mathrm{a}}(3.4)$ & $3.41^{\mathrm{a}}(0.90)$ & $27.9^{\mathrm{a}}(2.5)$ & $1.58^{\mathrm{b}}(0.72)$ & $27.3^{\mathrm{a}}(2.8)$ & $11.3(1.2)$ \\
\hline \multicolumn{7}{|c|}{ Mid Summer (DOY 190-221, n=207) } \\
\hline $1.44^{\mathrm{b}}(0.50)$ & $37.4^{\mathrm{a}}(2.6)$ & $5.33^{\mathrm{a}}(0.23)$ & $30.5^{\mathrm{a}}(3.2)$ & $5.27^{\mathrm{ab}}(1.82)$ & $29.2^{\mathrm{a}}(2.6)$ & $13.2(0.2)$ \\
\hline \multicolumn{7}{|c|}{ Late Summer (DOY 222-255, $n=207$ ) } \\
\hline $1.58^{\mathrm{b}}(0.57)$ & $35.6^{\mathrm{a}}(2.5)$ & $5.83^{\mathrm{a}}(0.35)$ & $28.7^{\mathrm{a}}(3.1)$ & $5.20^{\mathrm{a}}(1.40)$ & $27.3^{\mathrm{a}}(2.3)$ & $13.6(0.4)$ \\
\hline
\end{tabular}


Appendix D Repeated measures analysis using mixed models in JMP

\section{D.1 Mixed model analysis of factors affecting $\mathrm{CH}_{4}$ fluxes}

Output of JMP mixed model analysis where the $\log$ transform of $\mathrm{CH}_{4}$ fluxes for manually sampled days is treated as the response with community as a fixed effect, chamber as a random effect and covariates including: barometric pressure, $10 \mathrm{~cm}$ peat temperature and WT from each chamber, and $50 \mathrm{~cm}$ peat temperature from the tower.

\begin{tabular}{|c|c|c|c|}
\hline \multicolumn{4}{|c|}{$\begin{array}{l}\text { - Response log(CH4+2) (mg/m2/hr) } \\
\text { v Whole Model }\end{array}$} \\
\hline \multicolumn{4}{|l|}{ Effect Summary } \\
\hline $\begin{array}{l}\text { Source } \\
\text { Ttower_50cm } \\
\text { Community*Ttower_50cm } \\
\text { BarometricP } \\
\text { Community*BarometricP } \\
\text { Tsoil_10cm_chamberTtow } \\
\text { WT_Chamber } \\
\text { Tsoil_10cm_chamber*Baror } \\
\text { Community } \\
\text { Tsoil_10cm_chamber } \\
\text { BarometricP*Ttower_50cm } \\
\text { BarometricP*WT_Chamber } \\
\text { Tsoil_10cm_chamber*WT_C } \\
\text { Community*Tsoil_10cm_ch } \\
\text { Community*WT_Chamber } \\
\text { WT_Chamber*Ttower_50cn }\end{array}$ & $\begin{array}{l}\text { er_50cm } \\
\text { netricP } \\
\text { Chamber } \\
\text { amber } \\
\text { n }\end{array}$ & \begin{tabular}{r|} 
goWorth \\
88.657 \\
25.308 \\
6.818 \\
5.169 \\
3.142 \\
1.788 \\
1.295 \\
1.110 \\
0.974 \\
0.384 \\
0.334 \\
0.228 \\
0.182 \\
0.157 \\
0.022 \\
\end{tabular} & $\begin{array}{l}\text { PValue } \\
0.00000 \\
0.00000 \\
0.00000 \\
0.00001 \\
0.00072 \\
0.01629 \\
0.05065 \\
0.07770 \\
0.10612 \\
0.41309 \\
0.46295 \\
0.59097 \\
0.65788 \\
0.69711 \\
0.95003\end{array}$ \\
\hline \multicolumn{4}{|l|}{$\underline{\text { Remove }}$ Add Edit Undo $\square$ FDR } \\
\hline \multicolumn{4}{|l|}{ Summary of Fit } \\
\hline $\begin{array}{l}\text { RSquare } \\
\text { RSquare Adj } \\
\text { Root Mean Square Error } \\
\text { Mean of Response } \\
\text { Observations (or Sum Wgts) }\end{array}$ & $\begin{array}{r}0.865741 \\
0.862359 \\
0.180499 \\
1.429272 \\
815\end{array}$ & & \\
\hline
\end{tabular}




\begin{tabular}{|c|c|c|c|c|c|c|}
\hline \multicolumn{7}{|c|}{ REML Varıance Component Estımates } \\
\hline n Effect & Var Ratio & $\begin{array}{r}\text { Var } \\
\text { Component }\end{array}$ & Std Error & 95\% Lower & $95 \%$ Up & $\begin{array}{r}\text { Pct of } \\
\text { Total }\end{array}$ \\
\hline jer[Community] & 2.9872185 & 0.0973232 & 0.0566209 & -0.013652 & 0.2082981 & 74.920 \\
\hline Residual & & 0.0325799 & 0.0016413 & 0.0295879 & 0.0360522 & 25.080 \\
\hline & & 0.1299031 & 0.0566438 & 0.0643588 & 0.3860533 & 100.000 \\
\hline
\end{tabular}

-2 LogLikelihood $=-274.8156033$

Note: Total is the sum of the positive variance components.

Total including negative estimates $=0.1299031$

- Covariance Matrix of Variance Component Estimates

- Iterations

$\checkmark$ Fixed Effect Tests

Source

Community

Tsoil_10cm_chamber

BarometricP

WT_Chamber

Ttower_50cm

Community ${ }^{*}$ Tsoil_10 $10 \mathrm{~cm} \_$chamber

Community*BarometricP

Community*WT_Chamber

Community*Ttower_50cm

Tsoil_10cm_chamber*BarometricP

Tsoil_10cm_chamber*WT_Chamber

\begin{tabular}{|rrrrl} 
Nparm & DF & DFDen & F Ratio & Prob $>$ F \\
2 & 2 & 6.052 & 4.0135 & 0.0777 \\
1 & 1 & 794 & 2.6170 & 0.1061 \\
1 & 1 & 788.1 & 28.0691 & $<.0001^{*}$ \\
1 & 1 & 793.8 & 5.7958 & $0.0163^{*}$ \\
1 & 1 & 791.8 & 523.8658 & $<.0001^{*}$ \\
2 & 2 & 792.2 & 0.4189 & 0.6579 \\
2 & 2 & 788.1 & 12.0836 & $<.0001^{*}$ \\
2 & 2 & 793.1 & 0.3610 & 0.6971 \\
2 & 2 & 791.1 & 62.7842 & $<.0001^{*}$ \\
1 & 1 & 789.2 & 3.8315 & 0.0506 \\
1 & 1 & 788.7 & 0.2891 & 0.5910 \\
1 & 1 & 788.3 & 11.5246 & $0.0007^{*}$ \\
1 & 1 & 788.2 & 0.5393 & 0.4630 \\
1 & 1 & 788.9 & 0.6706 & 0.4131 \\
1 & 1 & 788.8 & 0.0039 & 0.9500
\end{tabular}

Tsoil_10cm_chamber'Ttower_50cm

Barometric ${ }^{*} W T$ Chamber

BarometricP*Ttower_50cm

WT_Chamber*Ttower_50cm 


\section{D.2 Mixed model analysis of factors affecting pore water $\mathrm{CH}_{4}$ concentrations}

Output of JMP mixed model analysis where the pore water $\mathrm{CH}_{4}$ concentration (DOY 155-255) is treated as the response with chamber as a random effect and DOC, TDN, depth-specific peat temperature and WT as covariates, and depth and community as fixed effects.

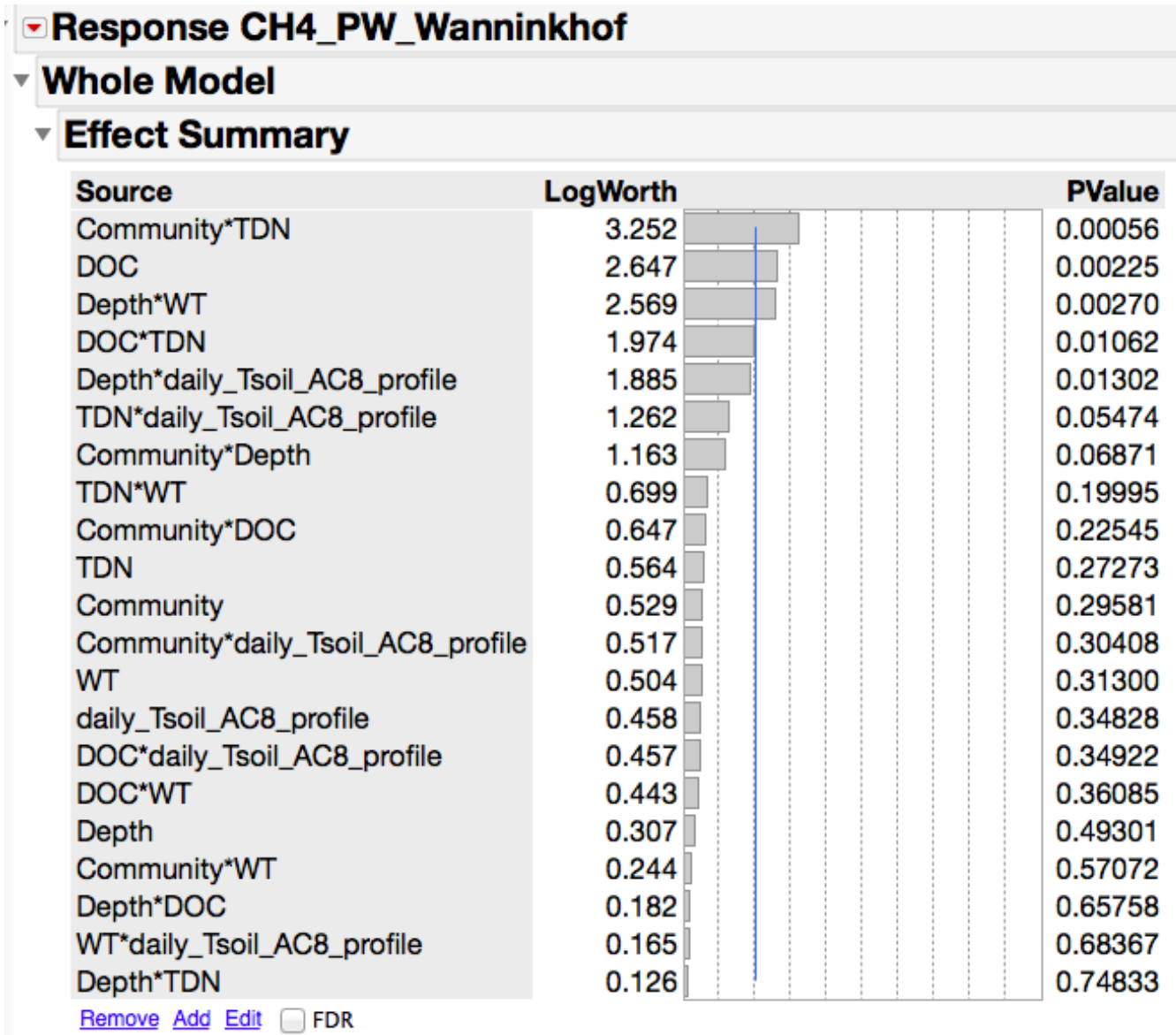

\begin{tabular}{lr}
\hline Summary of Fit & \\
\hline RSquare & 0.249179 \\
RSquare Adj & 0.203828 \\
Root Mean Square Error & 146.3941 \\
Mean of Response & 246.1222 \\
\hline Observations (or Sum Wgts) & 475
\end{tabular}




$\begin{array}{lrrrrrr}\text { vEML Variance Component Estimates } & & \\ \text { Random Effect } & \text { Var Ratio Component } & \text { Std Error } & \text { 95\% Lower } & \text { 95\% Upper } & \begin{array}{r}\text { Pet of } \\ \text { Total }\end{array} \\ \text { Chamber[Community] } & 0.0227175 & 486.86377 & 595.98604 & -681.2474 & 1654.9749 & 2.221 \\ \text { Residual } & 21431.232 & 1441.7402 & 18864.108 & 24563.439 & 97.779 \\ \text { Total } & 21918.096 & 1531.1358 & 19201.481 & 25258.201 & 100.000\end{array}$

-2 LogLikelihood = 5984.5265908

Note: Total is the sum of the positive variance components.

Total including negative estimates $=21918.096$

- Covariance Matrix of Variance Component Estimates

- Iterations

$\checkmark$ Fixed Effect Tests

Source

Community

Depth

$\mathrm{DOC}$

TDN

WT

daily_Tsoil_AC8_profile

Community*Depth

Community*DOC

Community*TDN

Community*WT

Community*daily_Tsoil_AC8_profile

Depth*DOC

Depth^TDN

Depth*WT

Depth*daily_Tsoil_AC8_profile

DOC*TDN

DOC*WT

DOC*daily_Tsoil_AC8_profile

TDN*WT

TDN*daily_Tsoil_AC8_profile

WT*daily_Tsoil_AC8_profile

$\begin{array}{rrrrr}\text { Nparm } & \text { DF } & \text { DFDen } & \text { F Ratio } & \text { Prob }>\text { F } \\ 2 & 2 & 8.53 & 1.4098 & 0.2958 \\ 1 & 1 & 445.2 & 0.4707 & 0.4930 \\ 1 & 1 & 362.8 & 9.4639 & 0.0023^{*} \\ 1 & 1 & 446.9 & 1.2059 & 0.2727 \\ 1 & 1 & 111.8 & 1.0272 & 0.3130 \\ 1 & 1 & 441.3 & 0.8816 & 0.3483 \\ 2 & 2 & 445.7 & 2.6941 & 0.0687 \\ 2 & 2 & 406.3 & 1.4951 & 0.2254 \\ 2 & 2 & 446.2 & 7.6141 & 0.0006^{*} \\ 2 & 2 & 82.23 & 0.5647 & 0.5707 \\ 2 & 2 & 446 & 1.1937 & 0.3041 \\ 1 & 1 & 435 & 0.1967 & 0.6576 \\ 1 & 1 & 447 & 0.1031 & 0.7483 \\ 1 & 1 & 444.2 & 9.1017 & 0.0027^{*} \\ 1 & 1 & 446.2 & 6.2161 & 0.0130^{*} \\ 1 & 1 & 446.7 & 6.5832 & 0.0106^{*} \\ 1 & 1 & 444.3 & 0.8367 & 0.3608 \\ 1 & 1 & 445.6 & 0.8781 & 0.3492 \\ 1 & 1 & 446.6 & 1.6476 & 0.1999 \\ 1 & 1 & 446.3 & 3.7093 & 0.0547 \\ 1 & 1 & 446.3 & 0.1662 & 0.6837\end{array}$


Output of JMP mixed model analysis where the pore water $\mathrm{CH}_{4}$ concentration (DOY 212-255) is treated as the response with chamber as a random effect and DOC, TDN, depth-specific peat temperature and WT as covariates, and depth and community as fixed effects.

\begin{tabular}{|c|c|c|}
\hline \multicolumn{3}{|c|}{-Response CH4_PW_Wanninkhof } \\
\hline \multicolumn{3}{|l|}{ v Whole Model } \\
\hline \multicolumn{3}{|l|}{$\checkmark$ Effect Summary } \\
\hline Source & LogWorth & PValue \\
\hline Community*TDN & 4.304 & 0.00005 \\
\hline TDN & 2.206 & 0.00623 \\
\hline TDN*WT & 1.916 & 0.01213 \\
\hline DOC*TDN & 1.804 & 0.01571 \\
\hline Community & 1.439 & 0.03640 \\
\hline TDN*daily_Tsoil_AC8_profile & 0.740 & 0.18212 \\
\hline Community*DOC & 0.594 & 0.25490 \\
\hline DOC*daily_Tsoil_AC8_profile & 0.441 & 0.36264 \\
\hline $\mathrm{DOC}{ }^{*} \mathrm{WT}$ & 0.427 & 0.37370 \\
\hline Depth & 0.394 & 0.40343 \\
\hline Community*daily_Tsoil_AC8_profile & 0.354 & 0.44308 \\
\hline Depth*daily_Tsoil_AC8_profile & 0.351 & 0.44606 \\
\hline daily_Tsoil_AC8_profile & 0.296 & 0.50595 \\
\hline WT*daily_Tsoil_AC8_profile & 0.225 & 0.59555 \\
\hline Depth*WT & 0.108 & 0.77935 \\
\hline WT & 0.108 & 0.77985 \\
\hline Community*WT & 0.081 & 0.83010 \\
\hline Depth*DOC & 0.066 & 0.85868 \\
\hline DOC & 0.031 & 0.93113 \\
\hline Depth*TDN & 0.017 & 0.96260 \\
\hline Community*Depth & 0.017 & 0.96260 \\
\hline
\end{tabular}

\begin{tabular}{lr}
\hline Summary of Fit & \\
\hline RSquare & 0.307449 \\
RSquare Adj & 0.219661 \\
Root Mean Square Error & 148.2043 \\
Mean of Response & 261.9299 \\
\hline Observations (or Sum Wgts) & 241 \\
\hline
\end{tabular}




\section{- REML Variance Component Estimates

\begin{tabular}{lrrrrrr} 
& \multicolumn{3}{c}{ Var } & & & Pct of \\
Random Effect & Var Ratio & Component & Std Error & 95\% Lower & 95\% Upper & Total \\
Chamber[Community] & -0.016774 & -368.4243 & 468.19292 & -1286.066 & 549.21696 & 0.000 \\
Residual & 21964.523 & 2150.2659 & 18291.801 & 26872.615 & 100.000 \\
Total & 21964.523 & 2150.2659 & 18291.801 & 26872.615 & 100.000
\end{tabular}

-2 LogLikelihood $=2944.9847446$

Note: Total is the sum of the positive variance components.

Total including negative estimates $=21596.098$

\section{- Covariance Matrix of Variance Component Estimates}

\section{- Iterations}

\section{$\checkmark$ Fixed Effect Tests}

Source

Community

Depth

DOC

TDN

WT

daily_Tsoil_AC8_profile

Community*Depth

Community*DOC

Community*TDN

Community*WT

Community*daily_Tsoil_AC8_profile

Depth*DOC

Depth`TDN

Depth*WT

Depth*daily_Tsoil_AC8_profile

DOC*TDN

DOC*WT

DOC*daily_Tsoil_AC8_profile

TDN*WT

TDN*daily_Tsoil_AC8_profile

WT*daily_Tsoil_AC8_profile

$\begin{array}{rrrrr}\text { Nparm } & \text { DF } & \text { DFDen } & \text { F Ratio } & \text { Prob }>\text { F } \\ 2 & 2 & 9.669 & 4.7589 & 0.0364^{*} \\ 1 & 1 & 211.9 & 0.7009 & 0.4034 \\ 1 & 1 & 148 & 0.0075 & 0.9311 \\ 1 & 1 & 209.3 & 7.6374 & 0.0062^{*} \\ 1 & 1 & 18.74 & 0.0804 & 0.7798 \\ 1 & 1 & 211.8 & 0.4439 & 0.5059 \\ 2 & 2 & 212.4 & 0.0381 & 0.9626 \\ 2 & 2 & 75.69 & 1.3919 & 0.2549 \\ 2 & 2 & 193.6 & 10.4347 & <.0001^{*} \\ 2 & 2 & 15.81 & 0.1884 & 0.8301 \\ 2 & 2 & 202.5 & 0.8173 & 0.4431 \\ 1 & 1 & 212.3 & 0.0318 & 0.8587 \\ 1 & 1 & 211.8 & 0.0022 & 0.9626 \\ 1 & 1 & 212.2 & 0.0787 & 0.7793 \\ 1 & 1 & 191.3 & 0.5831 & 0.4461 \\ 1 & 1 & 212.9 & 5.9300 & 0.0157^{*} \\ 1 & 1 & 209.8 & 0.7947 & 0.3737 \\ 1 & 1 & 212.5 & 0.8323 & 0.3626 \\ 1 & 1 & 212.7 & 6.4007 & 0.0121^{*} \\ 1 & 1 & 213 & 1.7919 & 0.1821 \\ 1 & 1 & 209.5 & 0.2826 & 0.5956\end{array}$




\section{D.3 Mixed model analysis of factors affecting $\delta^{13} \mathrm{C}-\mathrm{CH}_{4}$ source signatures}

Output of JMP mixed model analysis where the $\delta^{13} \mathrm{C}-\mathrm{CH}_{4}$ source signature is treated as the response with chamber as a random effect and mean pore water $\mathrm{CH}_{4}$ concentration, $\log \mathrm{CH}_{4}$ flux, $10 \mathrm{~cm}$ peat temperature and WT as covariates, and community as a fixed effect.

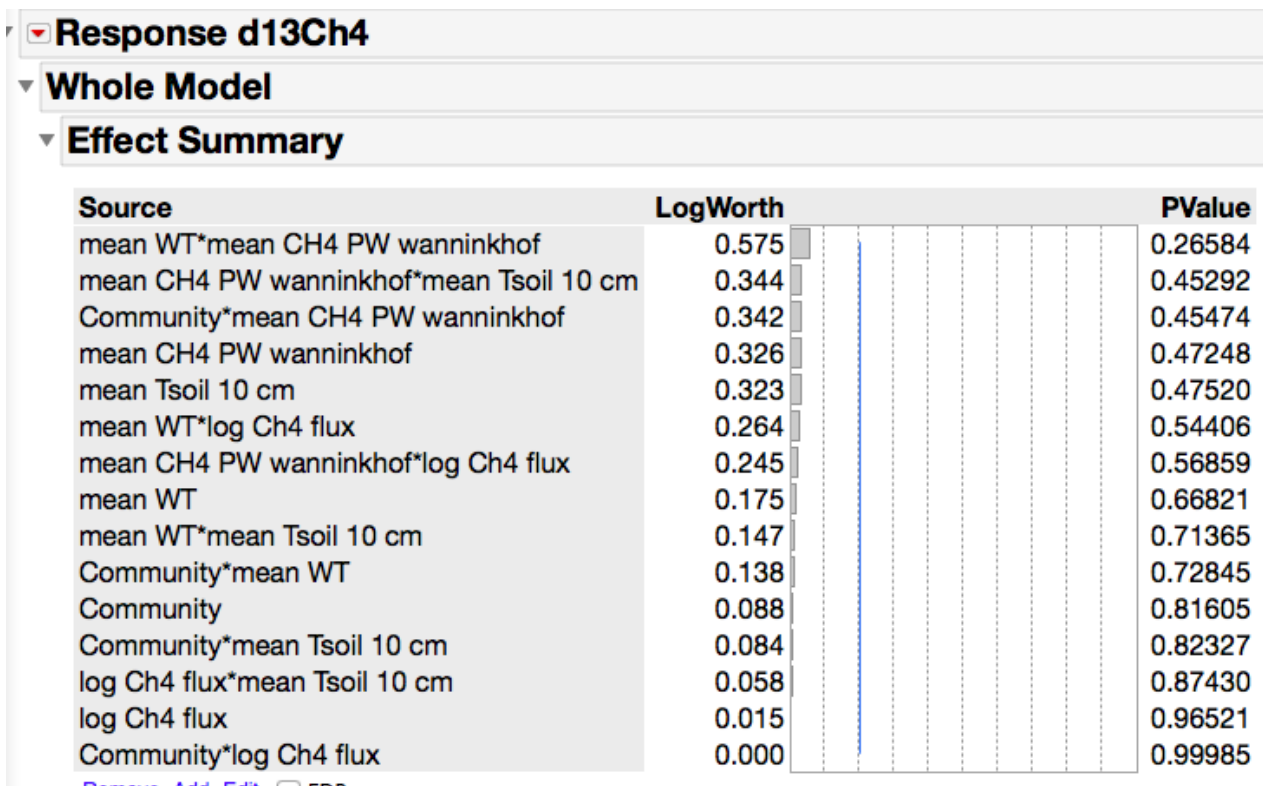

\begin{tabular}{l|r}
\hline Summary of Fit & \\
\hline RSquare & 0.404831 \\
RSquare Adj & 0.114505 \\
Root Mean Square Error & 4.83897 \\
Mean of Response & -75.2857 \\
\hline Observations (or Sum Wgts) & 62
\end{tabular}




\begin{tabular}{|c|c|c|c|c|c|c|}
\hline \multicolumn{7}{|c|}{ REML Variance Component Estimates } \\
\hline Random Effect & Var Ratio & $\begin{array}{r}\text { Var } \\
\text { Component }\end{array}$ & Std Error & 95\% Lower & 95\% Upper & $\begin{array}{l}\text { Pct of } \\
\text { Total }\end{array}$ \\
\hline Chamber[Community] & 0.3836872 & 8.984279 & 11.203353 & -12.97389 & 30.942447 & 27.729 \\
\hline Residual & & 23.415634 & 5.4230701 & 15.585278 & 39.105004 & 72.271 \\
\hline Total & & 32.399913 & 11.8092 & 17.696678 & 77.458618 & 100.000 \\
\hline
\end{tabular}

Total including negative estimates $=32.399913$

\begin{tabular}{|c|c|c|c|c|c|}
\hline $\begin{array}{l}\text { Covariance Matrix of } \\
\text { Variance Component Estimates }\end{array}$ & & & & & \\
\hline \multicolumn{6}{|l|}{ Iterations } \\
\hline \multicolumn{6}{|l|}{$\checkmark$ Fixed Effect Tests } \\
\hline Source & Nparm & DF & DFDen & F Ratio & Prob $>\mathbf{F}$ \\
\hline Community & 2 & 2 & 5.668 & 0.2107 & 0.8161 \\
\hline mean $\mathrm{WT}$ & 1 & 1 & 34.36 & 0.1869 & 0.6682 \\
\hline mean $\mathrm{CH} 4 \mathrm{PW}$ wanninkhof & 1 & 1 & 39.34 & 0.5263 & 0.4725 \\
\hline $\log$ Ch4 flux & 1 & 1 & 9.521 & 0.0020 & 0.9652 \\
\hline mean Tsoil $10 \mathrm{~cm}$ & 1 & 1 & 31.58 & 0.5223 & 0.4752 \\
\hline Community*mean WT & 2 & 2 & 39.87 & 0.3194 & 0.7285 \\
\hline Community*mean $\mathrm{CH} 4 \mathrm{PW}$ wanninkhof & 2 & 2 & 38.47 & 0.8044 & 0.4547 \\
\hline Community*log Ch4 flux & 2 & 2 & 9.335 & 0.0002 & 0.9998 \\
\hline Community*mean Tsoil $10 \mathrm{~cm}$ & 2 & 2 & 31.45 & 0.1957 & 0.8233 \\
\hline mean $\mathrm{WT}^{*}$ mean $\mathrm{CH} 4 \mathrm{PW}$ wanninkhof & 1 & 1 & 37.96 & 1.2754 & 0.2658 \\
\hline mean $W T^{\star} \log$ Ch4 flux & 1 & 1 & 40.68 & 0.3743 & 0.5441 \\
\hline mean $W^{*}$ mean Tsoil $10 \mathrm{~cm}$ & 1 & 1 & 37.94 & 0.1367 & 0.7136 \\
\hline mean $\mathrm{CH} 4 \mathrm{PW}$ wanninkhof*log Ch4 flux & 1 & 1 & 38.15 & 0.3307 & 0.5686 \\
\hline mean $\mathrm{CH} 4 \mathrm{PW}$ wanninkhof*mean Tsoil $10 \mathrm{~cm}$ & 1 & 1 & 37.97 & 0.5751 & 0.4529 \\
\hline log Ch4 flux*mean Tsoil $10 \mathrm{~cm}$ & 1 & 1 & 40.43 & 0.0253 & 0.8743 \\
\hline
\end{tabular}




\subsection{REFERENCES}

Adkinson AC (2009) Responses of Sphagnum productivity and net ecosystem exchange of $\mathrm{CO}_{2}$ to modifications of moss moisture content in an ombrotrophic bog. M.Sc. Thesis. Carleton University, Ottawa, ON.

Avery GB, Shannon RD, White JR, Martens CS, Alperin MJ (1999) Effect of seasonal changes in the pathways of methanogenesis on the delta-13C values of pore water in a Michigan peatland. Global Biogeochemical Cycles, 13(2), 475-484.

Bain CG, Bonn A, Stoneman R et al. (2011) IUCN UK Commission of Inquiry on Peatlands. IUCN UK Peatland Programme, Edinburgh.

Bardgett RD, Manning P, Morriën E, De Vries FT (2013) Hierarchical responses of plant-soil interactions to climate change: consequences for the global carbon cycle. Journal of Ecology, 101, 334-343.

Bartlett KB, Harriss RC (1993) Review and assessment of methane emissions from wetlands. Chemosphere, 26(1-4), 261-320.

Bender M, Conrad R (1995) Effects of $\mathrm{CH}_{4}$ concentrations and soil conditions on the induction of $\mathrm{CH}_{4}$ oxidation activity. Soil Biology and Biochemistry, 27(12), 15171527.

Bergman I, Klarqvist M, Nilsson M (2000) Seasonal variation in rates of methane production from peat of various botanical origins: effects of temperature and substrate quality. Microbiology Ecology, 33(3), 181-189.

Blodau C (2001) Carbon biogeochemistry in northern peatlands: regulation by environmental and biogeochemical factors. Ph.D. Thesis. McGill University, Montréal, QC.

Blodau C (2002) Carbon cycling in peatlands-- a review of processes and controls. Environmental Reviews, 10(2), 111-134.

Blodau C, Moore TR (2002) Macroporosity affects water movement and pore water sampling in peat soils. Soil Science, 167(2), 98-109.

Blodau C, Moore TR (2003a) Experimental response of peatland carbon dynamics to a water table fluctuation. Aquatic Sciences, 65, 47-62.

Blodau C, Moore TR (2003b) Micro-scale $\mathrm{CO}_{2}$ and $\mathrm{CH}_{4}$ dynamics in a peat soil during a water fluctuation and sulphate pulse. Soil Biology and Biochemistry, 35, 535-547.

Blodau C, Roulet NT, Heitmann T et al. (2007) Belowground carbon turnover in a temperate ombrotrophic bog. Global Biogeochemical Cycles, 21, GB1021.

Bridgham SD, Megonigal JP, Keller JK, Bliss NB, Trettin C (2006) The carbon balance of North American wetlands. Wetlands, 26(4), 889-916. 
Bridgham SD, Cadillo-Quiroz H, Keller JK, Zhuang Q (2013) Methane emissions from wetlands: biogeochemical, microbial, and modeling perspectives from local to global scales. Global Change Biology, 19(5), 1325-1346.

Brock FV, Richardson SJ (2001) Meteorological Measurement Systems. Oxford University Press, New York.

Brown MG, Humphreys ER, Moore TR, Roulet NT, Lafleur PM (2014) Evidence for a nonlinear relationship between ecosystem-scale peatland methane emissions and water table depth. Journal of Geophysical Research: Biogeosciences, 119, 826835 .

Bubier JL (1995) The relationship of vegetation to methane emission and hydrochemical gradients in northern peatlands. Journal of Ecology, 83, 403-420.

Bubier JL, Moore TR, Juggins S (1995a) Predicting methane emissions from bryophyte distribution in northern Canadian peatlands. Ecology, 76, 677-693.

Bubier JL, Moore TR, Bellisario L, Comer NT, Crill PM (1995b) Ecological controls on methane emissions from a northern peatland complex in the zone of discontinuous permafrost, Manitoba, Canada. Global Biogeochemical Cycles, 9, 455-470.

Bubier JL, Moore TR, Crosby G (2006) Fine-scale vegetation distribution in a cool temperate peatland. Canadian Journal of Botany, 84(6), 910-923.

Chanton JP, Whiting GJ (1995) Trace gas exchange in freshwater and coastal marine environments: Ebullition and transport by plants. In Biogenic Trace Gases: Measuring Emissions from Soil and Water (eds. Matson PA, and Harriss RC), pp. 98-125. Wiley-Blackwell, Oxford, UK.

Chanton JP (2005) The effect of gas transport on the isotope signature of methane in wetlands. Organic Geochemistry, 36, 753-768.

Chanton JP, Chaser LC, Glasser P, Siegel D (2005) Chapter 6: Carbon and hydrogen isotopic effects in microbial methane from terrestrial environments. In Stable Isotopes and Biosphere-Atmosphere Interactions: Processes and Biological Controls (eds. Flanagan LB, Ehleringer JR, Pataki DE), pp. 85-105. Elsevier, Amsterdam, NL.

Chanton JP, Glaser PH, Chasar LS, et al. (2008) Radiocarbon evidence for the importance of surface vegetation on fermentation and methanogenesis in contrasting types of boreal peatlands. Global Biogeochemical Cycles, 22, GB4022.

Chawanakul S, Chaiprasert P, Towprayoon S, Tanticharoen M (2009) Contributions of available substrates and activities of trophic microbial community to methanogenesis in vegetative and reproductive rice rhizospheric soil. Journal of environmental biology, 30(1), 119-127. 
Christensen TR, Jackowicz-Korczynski M, Aurela M et al. (2012) Monitoring the multiyear carbon balance of a subarctic palsa mire with micrometeorological techniques. Ambio (Royal Swedish Academy of Sciences), 41(Supplement 3), 207217.

Clark ID, Fritz P (1997) Environmental Isotopes in Hydrogeology. Lewis Publishers, Boca Raton.

Coleman DD, Risatti JB, Schoell M (1981) Fractionation of carbon and hydrogen isotopes by methane-oxidizing bacteria. Geochimica et Cosmochimica Acta, 45, 1033-1037.

Coles JRP, Yavitt JB (2002) Control of methane metabolism in a forested northern wetland, New York State, by aeration, substrates, and peat size fractions. Geomicrobiology Journal, 19, 293-315.

Couwenberg J, Thiele A, Tanneberger F et al. (2011) Assessing greenhouse gas emissions from peatlands using vegetation as a proxy. Hydrobiologia, 674, 67-89.

Dawson TE, Siegwolf RTW (eds) (2007) Stable isotopes as indicators of ecological change. Academic Press-Elsevier, San Diego, CA.

Demidenko E (2004) Mixed models: theory and applications. John Wiley \& Sons, New Jersey.

Deppe MA, Knorr KH, McKnight DM, Blodau C (2010a) Effects of short-term drying and irrigation on $\mathrm{CO} 2$ and $\mathrm{CH} 4$ production and emission from mesocosms of a northern bog and an alpine fen. Biogeochemistry, 100, 89-103.

Deppe MA, McKnight DM, Blodau C (2010b) Effects of short-term drying and irrigation on electron flow in mesocosms of a northern bog and an alpine fen.

Environmental Science \& Technology, 44, 80-86.

Dias ATC, Hoorens B, Van Logtestijn RSP, Vermaat JE, Aerts R (2010) Plant species composition can be used as a proxy to predict methane emissions in Peatland ecosystems after land-use changes. Ecosystems, 13, 526-538.

Dorodnikov M, Marushchak M, Biasi C, Wilmking M (2013) Effect of microtopography on isotopic composition of methane in porewater and efflux at a boreal peatland. Boreal Environment Research, 18, 269-279.

Dunfield P, Knowles R, Dumont R, Moore TR (1993) Methane production and consumption in temperate and subarctic peat soils: Response to temperature and pH. Soil Biology and Biochemistry, 25(3), 321-326.

Environment Canada (2014) 1981-2010 Canadian Climate Normals and Averages.

Farquhar GD, Ehleringer JR, Hubick KT (1989) Carbon isotope discrimination and photosynthesis. Annual Review of Plant Physiology and Plant Molecular Biology, 40, 503-537. 
Fechner-Levy EJ, Hemond HF (1996) Trapped methane volume and potential effects on methane ebullition in a northern peatland. Limnology and Oceanography, 41(7), 1375-1383.

Fenchel T, King GM, Blackburn TH (1998) Bacterial Biogeochemistry. Academic Press, London.

Frenzel P, Rudolph J (1998) Methane emission from a wetland plant: the role of $\mathrm{CH}_{4}$ oxidation in Eriophorum. Plant and Soil, 202(1), 27-32.

Friborg T, Christensen TR, Hansen BU, Nordstroem C, Soegaard H (2000) Trace gas exchange in a high-Arctic valley: 2. Landscape $\mathrm{CH} 4$ fluxes measured and modeled using eddy correlation data. Global Biogeochemical Cycles, 14, 715723.

Fung TWK, Xu XC (2010) Estimation and robustness of linear mixed models in credibility context. Casualty Actuarial Society, 2(1), 66-80.

Galand PE, Saarnio S, Fritze H, Yrjälä K (2002) Depth related diversity of methanogen Archaea in Finnish oligotrophic fen. FEMS Microbiology Ecology, 42, 441-449.

Galand PE, Fritze H, Conrad R, Yrjälä K (2005) Pathways for methanogenesis and diversity of methanogenic archaea in three boreal peatland ecosystems. Applied and Environmental Microbiology, 71(4), 2195-2198.

Galand PE, Yrjälä K, Conrad R (2010) Stable carbon isotope fractionation during methanogenesis in three boreal peatland ecosystems. Biogeosciences, 7, 38933900 .

Gallego-Sala AV, Prentice IC (2013) Blanket peat biome endangered by climate change. Nature Climate Change, 3, 152-155.

Gao F, Deng J, Li Q, Hu L, Zhu J, Hang H, Hu W (2012) A new collector for in situ pore water sampling in wetland sediment. Environmental Technology, 33(3), 257-264.

Garcia JL, Patel BKC, Ollivier B (2000) Taxonomic, phylogenetic, and ecological diversity of methanogenic Archaea. Anaerobe, 6(4), 205-226.

Glaser PH, Chanton JP, Morin P et al. (2004) Surface deformations as indicators of deep ebullition fluxes in a large northern peatland. Global Biogeochemical Cycles, 18, GB1003.

Google Earth (2013). Mer Bleue bog, 45²4’30.06” N 75³1’07.95” W. Sep. 24, 2013.

Gorham E (1991) Northern peatlands: role in the carbon cycle and probable responses to climatic warming. Ecological Applications, 1(2), 182-95.

Gorham E (1995) The biogeochemistry of northern peatlands and its possible response to global warming. In Biotic Feedbacks in the Global Climatic System: Will the 
Warming Feed the Warming? (eds. Woodwell GM, Mackenzie FT), pp. 169-187. Oxford University Press, New York, NY.

Gray A, Levy PE, Cooper MDA et al. (2013) Methane indicator values for peatlands: a comparison of species and functional groups. Global Change Biology, 19, 11411150 .

Große W (1996) The mechanism of thermal transpiration (= thermal osmosis). Aquatic Botany, 54(2-3), 101-110.

Hesslein RH (1976) An in-situ sampler for close interval pore water studies. Limnology and Oceanography, 21(6), 912-914.

Hornibrook ERC, Longstaffe FJ, Fyfe WS (1997) Spatial distribution of microbial methane production pathways in temperate zone wetland soils: stable carbon and hydrogen isotope evidence. Geochimica et Cosmochimica Acta, 61(4), 745-753.

Hornibrook ERC, Longstaffe FJ, Fyfe WS (2000a) Factors influencing stable isotope ratios in $\mathrm{CH}_{4}$ and $\mathrm{CO}_{2}$ within subenvironments of freshwater wetlands: implications for $\delta$-signatures of emissions. Isotopes in Environmental and Health Studies, 36, 151-176.

Hornibrook ERC, Longstaffe FJ, Fyfe WS, Bloom Y (2000b) Carbon-isotope ratios and carbon, nitrogen and sulfur abundances in flora and soil organic matter from a temperate-zone bog and marsh. Geochemical Journal, 34, 237-245.

Houweling S, Dentener F, Leliveld J et al. (2000) The modeling of tropospheric methane: how well can point measurements be reproduced by a global model? Journal of Geophysical Research, 105(D7), 8981-9002.

Hribljan JA (2012) The effect of long-term water table manipulations on vegetation, pore water, substrate quality, and carbon cycling in a northern poore fen peatland. Ph.D. Thesis. Michigan Technological University, Houghton, MI.

Hribljan JA, Kane ES, Pypker TG, Chimner RA (2014) The effect of long-term water table manipulations on dissolved organic carbon dynamics in a poor fen peatland. Journal of Geophysical Research: Biogeosciences, 119, 577-595.

IPCC (2007) Climate Change 2007: The Physical Science Basis. Contribution of Working Group 1 to the Fourth Assessment Report of the IPCC. Cambridge University Press, Cambridge.

IPCC (2013) Climate Change 2013: The Physical Science Basis. Contribution of Working Group 1 to the Fifth Assessment Report of the IPCC. Cambridge University Press, Cambridge.

JMP 7 Statistics and Graphics Guide. SAS Institute Inc., Cary, North Carolina. 
Kalbitz K, Solinger S, Park J-H, Michalzik B, Matzner E (2000) Controls on the dynamics of dissolved organic matter in soils: a review. Soil Science, 165(4), 277304.

Kamal S, Varma A (2008) Peatland microbiology. In Microbiology of Extreme Soils (eds. Dion P, Nautiyal CS), pp. 177-203. Springer-Verlag, Berlin Heidelberg. .

Kane ES, Mazzoleni LR, Kratz CJ, Hribljan JA, Johnson CP, Pypker TG, Chimner RA (2014) Peat porewater dissolved organic carbon concentration and lability increase with warming: a field temperature manipulation experiment in a poorfen. Biogeochemistry, 119, 161-178.

Keeling CD (1958) The concentration and isotopic abundances of atmospheric carbon dioxide in rural areas. Geochemica et Cosmochimica Acta, 13, 322-334.

Keeling CD (1960) The concentration and isotopic abundances of carbon dioxide in the atmosphere. Tellus A, 12, 200-203.

Kellner E, Price JS, Waddington JM (2004) Pressure variations in peat as a result of gas bubble dynamics. Hydrological Processes, 18, 2599-2605.

Kettunen A, Kaitala V, Lehtinen A et al. (1999) Methane production and oxidation potentials in relation to water table fluctuations in two boreal mires. Soil Biology \& Biochemistry, 31, 1741-1749.

Kim Y, Ullah S, Moore TR, Roulet NT (2014) Dissolved organic carbon and total dissolved nitrogen production by boreal soils and litter: the role of flooding, oxygen concentration and temperature. Biogeochemistry, 118, 35-48.

Kirschke S, Bousquet P, Ciais P et al. (2013) Three decades of global methane sources and sinks. Nature Geoscience, 6, 813-823.

Kirstine WV, Galbally IE (2012) Ethanol in the environment: a critical review of its roles as a natural product, a biofuel, and a potential environmental pollutant. Critical Reviews in Environmental Science and Technology, 42, 1735-1779.

Klass DL (1984) Methane from anaerobic fermentation. Science, 223(4640), 1021-1028.

Knorr K, Oosterwoud MR, Blodau C (2008) Experimental drought alters rates of soil respiration and methanogenesis but not carbon exchange in soil of a temperate fen. Soil Biology and Biochemistry, 40(7), 1781-1791.

Kobayashi H, Ryu Y, Baldocchi DD, Welles JM, Norman JM (2013) On the correct estimation of gap fraction: how to remove scattered radiation in gap fraction measurements? Agricultural and Forest Meteorology, 174-175, 170-183.

Kopp BJ, Fleckenstein JH, Roulet NT, Humphreys E, Talbot J, Blodau C (2013) Impact of long-term drainage on summer groundwater flow patterns in the Mer Bleue peatland, Ontario, Canada. Hydrology and Earth System Sciences, 17, 3485-3498. 
Kotsyurbenko OR, Chin K-J, Glagolev MV et al. (2004) Acetoclastic and hydrogenotrophic methane production and methanogenic populations in an acidic West-Siberian peat bog. Environmental Microbiology, 6(11), 1159-1173.

Kotsyurbenko OR, Friedrich MW, Simankova MV et al. (2007) Shift from acetoclastic to $\mathrm{H} 2$-dependent methanogenesis in a West Siberian peat bog at low $\mathrm{pH}$ values and isolation of an acidophilic Methanobacterium strain. Applied and Environmental Microbiology, 73(7), 2344-2348.

Lafleur PM, Roulet NT, Bubier JL, Frolking S, Moore TR (2003) Interannual variability in the peatland-atmosphere carbon dioxide exchange at an ombrotrophic bog. Global Biogeochemical Cycles, 17, 1036.

Lai DYF (2009) Methane dynamics in northern peatlands: a review. Pedosphere, 19(4), 409-421.

Lai DYF, Roulet NT, Humphreys ER, Moore TR, Dalva M (2012) The effect of atmospheric turbulence and chamber deployment period on autochamber $\mathrm{CO}_{2}$ and $\mathrm{CH}_{4}$ flux measurements in an ombrotrophic peatland. Biogeosciences, 9, 3305-22.

Lai DYF, Moore TR, Roulet NT (2014a) Spatial and temporal variations of methane flux measured by autochambers in a temperate ombrotrophic peatland. Journal of Geophysical Research: Biogeosciences, 5(119), 864-880.

Lai DYF, Roulet NT, Moore TR (2014b) The spatial and temporal relationships between $\mathrm{CO}_{2}$ and $\mathrm{CH}_{4}$ exchange in a temperate ombrotrophic bog. Atmospheric Environment, 89, 249-259.

Langmuir D (1971) Eh-pH determination. In Procedures in sedimentary petrology (ed. Carver RE), p.612. Wiley- Interscience, New York.

Larmola T, Bubier JL, Kobyljanec C et al. (2013) Vegetation feedbacks of nutrient addition lead to a weaker carbon sink in an ombrotrophic bog. Global Change Biology, 19(12), 3729-3739.

Le Mer J, Roger P (2001) Production, oxidation, emission, and consumption of methane by soils: a review. European Journal of Soil Biology, 37(1), 25-50.

Levy PE, Burden A, Cooper MDA et al. (2012) Methane emissions from soils: synthesis and analysis of a large UK data set. Global Change Biology, 18(5), 1657-1669.

Limpens J, Berendse F, Blodau C et al. (2008) Peatlands and the carbon cycle: from local processes to global implications- a synthesis. Biogeosciences, 5, 1475-1491.

Long KD, Flanagan LB, Cai T (2010) Diurnal and seasonal variation in methane emissions in a northern Canadian peatland measured by eddy covariance. Global Change Biology, 16, 2420-2435.

Lou T, Xie H (2006) Photochemical alteration of the molecular weight of dissolved organic matter. Chemosphere, 65, 2333-2342. 
Malmer N, Wallén B (2004) Input rates, decay losses and accumulation rates of carbon in bogs during the last millennium: internal processes and environmental changes. The Holocene, 14(1), 111-117.

Mansfeldt T (2003) In situ long-term redox potential measurements in a dyked marsh soil. Journal of Plant Nutrition and Soil Science, 166, 210-219.

Matthews E, Fung I (1987) Methane emission from natural wetlands: global distribution, area and environmental characteristics of sources. Global Biogeochemical Cycles, 1(1), 61-86.

Mikaloff Fletcher SE, Tans PP, Bruhwiler LM, Miller JB, Heimann M (2004a) $\mathrm{CH}_{4}$ source estimated from atmospheric observations of $\mathrm{CH}_{4}$ and its ${ }^{13} \mathrm{C} /{ }^{12} \mathrm{C}$ isotopic ratios: 1.Inverse modelling of source processes. Global Biogeochemical Cycles, 18, GB4004.

Mikaloff Fletcher SE, Tans PP, Bruhwiler LM, Miller JB, Heimann M (2004b) $\mathrm{CH}_{4}$ source estimated from atmospheric observations of $\mathrm{CH}_{4}$ and its ${ }^{13} \mathrm{C} /{ }^{12} \mathrm{C}$ isotopic ratios: 2.Inverse modelling of $\mathrm{CH} 4$ fluxes from geographic regions. Global Biogeochemical Cycles, 18, GB4004.

Miller, JB (2005) Chapter 16: The carbon isotopic composition of atmospheric methane and its constraint on the global methane budget. In Stable Isotopes and BiosphereAtmosphere Interactions: Processes and Biological Controls (eds. Flanagan LB, Ehleringer JR, Pataki DE), pp. 288-306. Elsevier, Amsterdam.

Miller JB, Tans PP (2003) Calculating isotopic fractionation from atmospheric measurements at various scales. Tellus B, 55(2), 207-214.

Moore TR, Roulet NT, Knowles R (1990) Spatial and temporal variations of methane flux from subarctic/northern boreal fens. Global Biogeochemical Cycles, 4(1), 2946.

Moore TR, Dalva M (1993) The influence of temperature and water table position on methane and carbon dioxide emissions from laboratory columns of peatland soils. Journal of Soil Science, 44(4), 651-664.

Moore TR, Roulet NT, Waddington JM (1998) Uncertainty in predicting the effect of climatic change on the carbon cycling of Canadian peatlands. Climatic Change, 40, 229-45.

Moore TR (2001) Chapitre 8: Les processus biogéochimiques liés au carbone. In Écologie des tourbières du Quebec-Labrador (eds. Payette S, Rochefort L), pp. 183-198. Les Presses de l'Université Laval, Québec.

Moore TR, Dalva M (2001) Some controls on the release of dissolved organic carbon by plant tissues and soils. Soil Science, 166(1), 38-47.

Moore TR, Bubier J, Lafleur P, Frolking S, Roulet N (2002) Plant biomass, production and $\mathrm{CO}_{2}$ exchange in an ombrotrophic bog. Journal of Ecology, 90, 25-36. 
Moore TR, De Young A, Bubier JL, Humphreys ER, Lafleur PM, Roulet NT (2011) A multi-year record of methane flux at the Mer Bleue bog, Southern Canada. Ecosystems, 14, 646-657.

Murphy MT, Moore TR (2010) Linking root production to aboveground plant characteristics and water table in a temperate bog. Plant and Soil, 336, 219-231.

Neef L, van Weele M, van Velthoven P (2010) Optimal estimation of the present-day global methane budget. Global Biogeochemical Cycles, 24, GB4024.

Nilsson M, Sagerfors J, Buffam I et al. (2008) Contemporary carbon accumulation in a boreal oligotrophic minerogenic mire- a significant sink after accounting for all C-fluxes. Global Change Biology, 14, 2317-2332.

Nykänen H, Alm J, Silvola J, Tolonen K, Martikainen PJ (1998) Methane fluxes on boreal peatlands of different fertility and the effect of long-term experimental lowering of the water table on flux rates. Global Biogechemical Cycles, 12(1), 5369.

Nykänen H, Vasander H, Huttunen JT, Martikainen PJ (2002) Effects of experimental nitrogen load on methane and nitrous oxide fluxes on ombrotrophic boreal peatland. Plant and Soil, 242, 147-155.

Oke TR (1987) Boundary Layer Climates: Second Edition. Routledge, New York.

Olefeldt D, Roulet NT (2012) Effects of permafrost and hydrology on the composition and transport of dissolved organic carbon in a subarctic peatland complex. Journal of Geophysical Research, 117, G01005.

Öquist M, Sundh I (1998) Effects of a transient oxic period on mineralization of organic matter to $\mathrm{CH}_{4}$ and $\mathrm{CO}_{2}$ in anoxic peat incubations. Geomicrobiology, 15, 325333.

Parmentier FJW, van Huissteden J, van der Molen MK et al. (2011) Spatial and temporal dynamics in eddy covariance observations of methane fluxes at a tundra site in northeastern Siberia. Journal of Geophysical Research, 116, G03016.

Pataki DE, Ehleringer JR, Flanagan LB et al. (2003) The application and interpretation of Keeling plots in terrestrial carbon cycle research. Global Biogeochemical Cycles, 17(1), 1022.

Petrescu AMR, van Beek LPH, van Huissteden, et al. (2010) Modeling regional to global $\mathrm{CH}_{4}$ emissions of boreal and arctic wetlands. Global Biogeochemical Cycles, 24, GB4009.

Petrescu AMR, Lohila A, Tuovinen J-P et al.(2015) The uncertain climate footprint of wetlands under human pressure. Proceedings of the National Academy of Sciences of the United States of America, 112(15), 4594-4599. 
Peuravuori J, Pihlaja K (1997) Molecular size distribution and spectroscopic properties of aquatic humic substances. Analytica Chimica Acta, 337, 133-149.

Picarro, Inc. (2015) Data sheet G2201-i CRDS analyzer for isotopic carbon in $\mathrm{CO}_{2}$ and $\mathrm{CH}_{4}$.

Pihlatie MK, Christiansen JR, Aaltonen H, et al. (2013) Comparison of static chambers to measure $\mathrm{CH}_{4}$ emissions from soils. Agirucultural and Forest Meteorology, 171, 124-136.

Preston MD, Eimers MC, Watmough SA (2011) Effect of moisture and temperature variation on DOC release from a peatland: conflicting results from laboratory, field and historical data analysis. Science of the Total Environment, 409, 12351242.

Quay PD, King SL, Stutsman J, et al. (1991) Carbon isotopic composition of atmospheric $\mathrm{CH}_{4}$ : fossil and biomass burning source strengths. Global Biogeochemical Cycles, 5(1), 25-47.

Rabenhorst MC, Hively WD, James BR (2009) Measurements of soil redox potential. Soil Science Society of America Journal, 73(2), 668-674.

Rattle J (2006) Dissolved nitrogen dynamics in an ombrotrophic bog. M.Sc. Thesis. McGill University, Montréal, QC.

Reay DS, Davidson EA, Smith KA et al. (2012) Global agriculture and nitrous oxide emissions. Nature Climate Change, 2(6), 410-416.

Rinne J, Riutta T, Pihlatie M et al. (2007) Annual cycle of methane emission from a boreal fen measured by the eddy covariance technique. Tellus B, 59(3), 449-457.

Rodwell JS (1991) British Plant Communities Volume 2: Mires and Heaths. Cambridge University Press, Cambridge.

Rosenberry DO, Glaser PH, Siegel DI (2006) The hydrology of northern peatlands as affected by biogenic gas: current developments and research needs. Hydrological Processes, 20(17), 3601-3610.

Roslev P, King GM (1994) Survival and recovery of methanotrophic bacteria starved under oxic and anoxic conditions. Applied and Environmental Microbiology, 60, 2602-2608.

Roslev P, King GM (1995) Aerobic and anaerobic starvation metabolism in methanotrophic bacteria. Applied and Environmental Microbiology, 61, 15631570 .

Roulet NT, Moore TR, Bubier J, Lafleur PM (1992) Northern fens: methane flux and climatic change. Tellus B, 44, 100-105. 
Roulet NT, Lafleur PM, Richard PJH, Moore TR, Humphreys ER, Bubier J (2007) Contemporary carbon balance and late Holocene carbon accumulation in a northern peatland. Global Change Biology, 13, 397-411.

Rydin H, Jeglum JK (2013) The Biology of Peatlands: Second Edition. Oxford University Press, Oxford.

Saleska S (2009) Genes, isotopes and ecosystem biogeochemistry: dissecting methane flux at the leading edge of global change, University of Arizona, Tuscon.

Segers R (1998) Methane production and methane consumption: a review of processes underlying wetland methane fluxes. Biogeochemistry, 41: 23-51

Shotyk W (1988) Review of the inorganic geochemistry of peats and peatland waters. Earth-Science Reviews, 25, 95-176.

SigmaXL (2015) Minimum sample size for robust t-tests and ANOVA. SigmaXL version 7.

Soegaard H, Nordstroem C, Friborg T, Hansen BU (2000) Trace gas exchange in a higharctic valley 3 . Integrating and scaling $\mathrm{CO} 2$ fluxes from canopy to landscape using flux data, footprint modeling, and remote sensing. Global Biogeochemical Cycles, 14(3), 725-744.

Steinmann P, Shotyk W (1996) Sampling anoxic pore waters in peatlands using "peepers" for in situ-filtration. Fresenius' Journal of Analytical Chemistry, 354, 709-713.

Strack M, Waller MF, Waddington JM (2006) Sedge succession and peatland methane dynamics: a potential feedback to climate change. Ecosystems, 9, 278-287.

Strack M, O'Brien JRP, Waddington JM (2008) Assessing the role of ecological succession for peatland methane dynamics: potential climate change feedback. Peatlands and climate change, International Peat Society, Jväskylä, Finland.

Stull RB (1995) Meteorology Today for Scientists and Engineers. West Publishing Company, St.Paul.

Stull RB (1988) An Introduction to Boundary Layer Meteorology. Kluwer Academic Publishers, Dordrecht.

Suyker AE, Verma SB, Clement RJ, Billesbach DP (1996). Methane flux in a boreal fen: Season-long measurement by eddy correlation. Journal of Geophysical Research, 101, 28,637-28,647.

Syed KH, Flanagan LB, Carlson PJ, Glenn AJ, Van Gaalen KE (2006) Environmental control of net ecosystem $\mathrm{CO}_{2}$ exchange in a treed, moderately rich fen in northern Alberta. Agricultural and Forest Meteorology, 140, 97-114. 
Thomas KL, Benstead J, Davies KL, Lloyd D (1996) Role of wetland plants in the diurnal control of $\mathrm{CH}_{4}$ and $\mathrm{CO}_{2}$ fluxes in peat. Soil Biology and Biochemistry, 28(1), 17-23.

Tokida T, Miyazaki T, Mizoguchi M et al. (2007) Falling atmospheric pressure as a trigger for methane ebullition from peatland. Global Biogeochemical Cycles, 21, GB2003.

Turetsky MR, Treat CC, Waldrop MP, Waddington JM, Harden JW, McGuire AD (2008) Short-term response of methane fluxes and methanogen activity to water table and soil warming manipulations in an Alaskan peatland. Journal of Geophysical Research, 113, G00A10.

Turetsky MR, Kotowska A, Bubier J et al. (2014) A synthesis of methane emissions from 71 northern, temperate, and subtropical wetlands. Global Change Biology, 20, 2183-2197.

Turunen J, Tomppo E, Tolonen K, Reinikainen A (2002) Estimating carbon accumulation rates of undrained mires in Finland- application to boreal and subarctic regions. The Holocene, 12, 69-80.

US EPA (2010) Methane and nitrous oxide emissions from natural sources.

Vasander H, Kettunen A (2006) Chapter 9: Carbon in boreal peatlands. In Boreal Peatland Ecosystems (ed. Wieder RK, Vitt DH), pp. 165-194. Springer-Verlag, Berlin Heidelberg.

Valentine DW, Holland EA, Schimel DS (1994). Ecosystem and physiological controls over methane production in northern wetlands. Journal of Geophysical Research, 99(D1), 1563-1571.

Vorenhout M, van der Geest HG, van Marum D, Wattel K, Eijsackers HJP (2004) Automated and continuous redox potential measurements in soil. Journal of Environmental Quality, 33, 1562-1567.

Vorenhout M, van der Geest HG, Hunting ER (2011) An improved datalogger and novel probes for continuous redox measurements in wetlands. International Journal of Environmental Analytical Chemistry, 91(7), 801-810.

Waddington JM, Ketcheson SJ, Kellner E, Strack M, Baird AJ (2009) Evidence that piezometers vent gas from peat soils and implications for pore-water pressure and hydraulic conductivity measurements. Hydrological Processes, 23(8), 1249-1254.

Walker MD, Wahren $\mathrm{CH}$, Hollister RD et al. (2006) Plant community responses to experimental warming across the tundra biome. Proceedings of the National Academy of Sciences of the United States of America, 103(5), 1342-1346.

Walter KM, Chanton JP, Chapin FS, Schuur EAG, Zimov SA (2008) Methane production and bubble emissions from arctic lakes: Isotopic implications for source pathways and ages. Journal of Geophysical Research, 113, G00A081342-1346. 
Wallace JM, Hobbs PV (1977) Atmospheric Science: An Introductory Survey. Academic Press, New York.

Wang M, Moore TR, Talbot J, Riley JL (2015) The stoichiometry of carbon and nutrients in peat formation. Global Biogeochemical Cycles, 29, 113-121.

Wanninkhof R (1992) Relationship between wind speed and gas exchange over the ocean. Journal of Geophysical Research, 97, 7373-7382.

Ward SE, Ostle NJ, Oakley S, Quirk H, Henrys PA, Bardgett RD (2013) Warming effects on greenhouse gas fluxes in peatlands are modulated by vegetation composition. Ecology Letters, 16, 1285-1293.

Weishaar JL, Aiken GR, Bergamaschi BA, Fram MS, Fujii R, Mopper K (2003) Evaluation of specific ultraviolet absorbance as an indicator of the chemical composition and reactivity of dissolved organic carbon. Environmental Science \& Technology, 37, 4702-4708.

Weiss RF (1974) Carbon dioxide in water and seawater: the solubility of a non-ideal gas. Marine Chemistry, 2, 2013-215.

Weiss RF, Price BA (1980) Nitrous oxide solubility in water and seawater. Marine Chemistry, 8, 347-359.

Werner C, Schnyder H, Cuntz M et al. (2012) Progress and challenges in using stable isotopes to trace plant carbon and water relations across scales. Biogeosciences, $\mathbf{9}$, 3083-3111.

Whalen SC (2005) Biogeochemistry of methane exchange between natural wetlands and the atmosphere. Environmental Engineering Science, 22(1), 73-94.

Whiticar MJ, Faber E, Schoell M (1986) Biogenic methane formation in marine and freshwater environments: $\mathrm{CO}_{2}$ reduction vs. acetate fermentation- isotopic evidence. Geochimica et Cosmochimica Acta, 50(5), 693-709.

Whitcar MJ (1999) Carbon and hydrogen isotope systematics of bacterial formation and oxidation of methane. Chemical Geology, 161, 291-314.

Whiticar, MJ (2000) Chapter 5: Can Stable Isotopes and Global Budgets Be Used to Constrain Atmospheric Methane Budgets? In Atmospheric Methane: Its Role in the Global Environment (ed. Khalil MAK), pp. 63-85. Springer-Verlag, Berlin Heidelberg.

Wiesenburg DA, Guinasso NL Jr. (1979) Equilibrium solubilities of methane, carbon monoxide, and hydrogen in water and sea water. Journal of Chemical and Engineering Data, 24(4), 356-360.

Wilson KS, Humphreys ER (2010) Carbon dioxide and methane fluxes from Arctic mudboils. Canadian Journal of Soil Science, 90, 441-449. 
Wuebbles D, Hayhoe K (2002) Atmospheric methane and global change. Earth-Science Reviews, 57, 177-210.

Yavitt JB, Lang GE (1990) Methane production in contrasting wetland sites: response to organic-chemical components of peat and to sulfate reduction. Geomicrobiology Journal, 8(1), 27-46.

Yavitt JB, Seidman-Zager M (2006) Methanogenic conditions in northern peat soils. Geomicrobiology Journal, 23, 119-127.

Zhi-Guang L (1985) Oxidation-reduction potential. In Physical Chemistry of Paddy Soils (ed. Tian-ren Y), pp. 1-26. Springer, Berlin. 